GABRIELA LIEBERKNECHT

Análise bibliométrica sobre a flotação de caulinita

São Paulo 2016 
GABRIELA LIEBERKNECHT

\title{
Análise bibliométrica sobre a flotação de caulinita
}

\author{
Dissertação apresentada à Escola \\ Politécnica da Universidade de São Paulo \\ para obtenção do título de Mestre em \\ Ciências.
}

Área de Concentração:

Engenharia Mineral

Orientador: Prof. Dr.

Laurindo de Salles Leal Filho 
GABRIELA LIEBERKNECHT

Análise bibliométrica sobre a flotação de caulinita

Dissertação apresentada à Escola

Politécnica da Universidade de São Paulo para obtenção do título de Mestre em Ciências. 
Este exemplar foi revisado e corrigido em relação à versão original, sob responsabilidade única do autor e com a anuência de seu orientador.

São Paulo, de de

Assinatura do autor:

Assinatura do orientador:

\section{Catalogação-na-publicação}

Lieberknecht, Gabriela

Análise bibliométrica sobre a flotação de caulinita / G. Lieberknecht -versão corr. -- São Paulo, 2016.

$177 \mathrm{p}$.

Dissertação (Mestrado) - Escola Politécnica da Universidade de São Paulo. Departamento de Engenharia de Minas e Petróleo.

1.Flotação 2.Bibliometria I.Universidade de São Paulo. Escola Politécnica. Departamento de Engenharia de Minas e Petróleo II.t. 
Com carinho, à Susana e Vitor. Principais responsáveis pela minha formação acadêmica e pessoal. 


\section{AGRADECIMENTOS}

Não existe construção que independentemente de sua grandeza se sustente por si só se não tiver uma base firme. Sendo assim, primeiramente quero agradecer aos meus pais, Vitor e Susana, que diante de todos os momentos felizes ou angustiantes, mesmo de longe, foram a minha base nessa caminhada. Pessoas de caráter indiscutível, exemplos de honestidade e determinação, que me fizeram chegar até aqui.

Aos meus irmãos, Eduardo e Victória, por me apoiarem e incentivarem sempre. Obrigada. Vocês são tudo para mim.

Ao meu orientador, Professor Laurindo, por ter me dado a oportunidade de fazer mestrado na USP e me convidado para trabalhar no LFQI. Obrigada por todos os ensinamos e ter expandido o meu conhecimento de uma forma indescritível.

À um anjo chamado Patricia Matai, a peça chave dessa dissertação. Não existem palavras que consigam demostrar toda minha gratidão. Obrigada pelos ensinamentos e por ter acreditado em mim. Além de minha professora e amiga, se tornou um dos meus maiores exemplos de vida. Obrigada.

Quero agradecer também à Simone, por ter sido minha família em São Paulo. Amiga e mãe de coração é exemplo mais nítido de bondade que eu conheço. Obrigada por ter sido meu alicerce nesses últimos anos.

Aos meus colegas de laboratório: Daniela, André, Marco, Frank, Thiago, Virginia e Fernanda. Aos meus colegas de pós-graduação: Thammiris, Helder, Rogério, Ana, Gabriel, Wellington, Tiago e Francisco. Obrigada por todo apoio e amizade, vocês foram essenciais.

Agradeço também a Eva, secretária do LFQI, por toda sua amizade e ter me ajudado sempre, obrigada. 
Aos meus amigos que foram responsáveis pelos meus maiores momentos de alegria em São Paulo. Minha maravilhosa amiga Josiane Cláudia e meus dois grandíssimos amigos Paulo e Romulo. Obrigada por nunca terem ficado distantes de mim, e por me incentivarem a continuar firme nesse sonho.

Ao meu amigo Gabriel Henrique, um irmão de coração que conheci na USP. Obrigada pela sua paciência, pela sua amizade e todos os seus conselhos.

Aos meus amigos; Sylvia, Amanda, Jessica e Leandro. Obrigada pelos finais de semanas maravilhosos ao lado de vocês.

A todos os meus Professores no PMI.

À Maristela e Marisa, secretárias do PMI, por todo auxílio nesses últimos dois anos.

À Maristela particularmente, quero agradecer por todas as nossas conversas que me incentivaram a continuar firme no sonho de realizar meu mestrado no PMI. Uma profissional de um caráter indiscutível. Obrigada.

A equipe responsável pela Biblioteca do PMI, muito obrigada por toda ajuda e dedicação.

À Ivani por todos os ensinamentos técnicos no LFQI.

Agradeço ao CAPES também pela bolsa concedida. 
Cada dia que amanhece assemelha-se a uma página em branco, na qual gravamos os nossos pensamentos, ações e atitudes. Na essência, cada dia é a preparação de nosso próprio amanhã.

(Chico Xavier) 


\section{RESUMO}

A bibliometria é um instrumento quantitativo que através de medidas matemáticas e estatísticas permite mapear e gerar informações que auxiliam na tomada de decisões de uma determinada área cientifica. Verificou-se o evidente crescimento da produção científica na área de flotação de caulinita e da significativa importância desse assunto em meios acadêmicos, realizou-se a necessidade de um estudo de natureza bibliométrica. Este estudo é uma maneira de observar a quantidade do que está sendo produzido, quais são os principais trabalhos desenvolvidos e quais foram os resultados atingidos.

O presente trabalho apresenta uma discussão de natureza bibliométrica sobre artigos publicados no mundo, relacionados sobre o assunto flotação de caulinita, em periódicos internacionais no período de 1992 e 2015. Através deste trabalho foi possível reconhecer e identificar quais são as tendências temáticas e metodológicas que estão sendo usadas, além dos principais coletores utilizados na flotação de caulinita. Os resultados mostram que é significativa a quantidade de artigos produzidos por autores chineses, especialmente a partir do ano de 2013, visto ser a China a maior produtora de alumínio no mundo, e a caulinita, é o rejeito no processo de flotação reversa do diásporo. Foram encontrados muitos estudos com propostas e estruturas semelhantes, utilizando métodos que são importantes para compreender os fenômenos físico-químicos na flotação, como: métodos de caracterização mineralógica, potencial zeta, métodos de adsorção e outros. Os artigos analisados tinham uma média de 7 páginas por artigo e todos foram pesquisados no SciVerse ScienceDirect, pertencente à editora Elsevier. Dos 39 artigos analisados, 31 possuem avaliação interdisciplinar da Coordenação de Aperfeiçoamento de Pessoal de Nível Superior (CAPES) e são classificados no estrato A1, que são artigos de mais alta qualidade. Os resultados mostraram a dificuldade de trabalhar com o tema de flotação de caulinita individualmente e confirmou que existe uma colaboração científica entre autores.

No estudo por palavras-chave, (ao todo 180) verificou-se a presença de termos como "aluminossilicatos", "minérios oxidados" e "diásporo" junto com o termo 
"caulinita", além de outras palavras-chave como "flotação" e "adsorção". Os minerais envolvidos na flotação junto com caulinita também foram avaliados, mineral diásporo aparece frequentemente relacionando com o mineral de interesse dessa dissertação. $\mathrm{Na}$ avaliação por citações pelo Scopus, os artigos foram classificados conforme sua importância no meio acadêmico. Além disso, através da análise bibliométrica verificouse que os reagentes utilizados nos testes de flotação de caulinita são de grande maioria derivados de nitrogenados catiônicos. Os valores de $\mathrm{pH}$ mais utilizado de flotação ocorreram em meio ácido, embora, muitos coletores apresentem também bons resultados em meio neutro e/ou alcalino. Observou-se também que ainda há muito para ser pesquisado, visto que a maior parte dos artigos amostrados realizam pesquisa em escala laboratorial e não descrevem a realidade das usinas de beneficiamento de caulinita no mundo.

Palavras-chave: Flotação de caulinita, Flotação, Caulinita, Bibliometria. 


\section{ABSTRACT}

Bibliometrics is a quantitative instrument that, through mathematical and statistical measures, allows to map and generate information that assists in the decision-making of a certain scientific area. In the area of kaolinite flotation, a clear growth of scientific production and a significant importance of this subject in academic areas were noted, thus warranting the need for a bibliometric study. This study is a way to observe the amount being produced, which are the main projects under development and which results have been obtained.

The current work presents a bibliometric discussion on articles published worldwide concerning kaolinite flotation in international journals from 1992 to 2015. This work allowed to recognize and identify which are the thematic and methodological trends that are being used, in addition to the main collectors used in kaolinite flotation. The results show that a significant amount of articles is produced by Chinese authors, especially from 2013 , as China is the largest aluminum producer in the world, and kaolinite is the reject in the reverse flotation process of diaspore. Many studies using methods that are important to understand physicochemical phenomena in flotation, with similar proposals and structures, were found, such as: mineralogical characterization methods, zeta potential, adsorption methods and others. Assessed articles had, on average, 7 pages each and all were searched in Elsevier's SciVerse ScienceDirect. Thirty-one out of the 39 analyzed articles have interdisciplinary evaluation of the Coordination for the Improvement of Higher Education Personnel (CAPES) and are rated at stratum A1, which corresponds to higher quality articles. The results showed the difficulty of working with kaolinite flotation individually and confirmed that there is scientific collaboration among authors.

The study by keyword (180 in total) found terms as "aluminosilicate", "oxidized ores" and "diaspore" together with "kaolinite", in addition to other keywords, such as "flotation" and "adsorption". Minerals involved in flotation together with kaolinite were also evaluated, and diaspore mineral frequently appears related to the mineral of interest of this dissertation. Articles were rated according to their importance in the academic world using the assessment of citations by Scopus. In addition, bibliometric 
analysis showed that reagents used in kaolinite flotation tests are mostly derived from cationic nitrogenated compounds. Most used $\mathrm{pH}$ values in flotation are acidic, although many collectors also have good results in neutral and/or alkaline media. It was also noted that there is still much to be researched, since most articles sampled researched in laboratory scale and do not describe the reality of processing plants of kaolinite in the world. 


\section{LISTA DE FIGURAS}

Figura 1 - Dupla camada elétrica das argilas (CHAGAS, sem data) .32

Figura 2 - Desenho de uma pedreira de caulim localizada em Kauling (CHEN,LIN e ZHENG, 1997)

Figura 3 - a - Tetraedro de sílica; b - folha tetraédrica; c - octaedro em que o átomo coordenado pode ser Al, Fe ou Mg; d - folha octaédrica; e - modelo esquemático da camada estrutural básica da caulinita (GOMES, 1988)

Figura 4 - Molécula de um tensoativo, parte hidrofóbica (polar) e parte hidrofílica (apolar) (Surfactants in Consumers Products, Apud NEDER, 2005) 39

Figura 5 - Classificação das aminas (Neder, 2005).

Figura 6 - Fluxograma com as rotas resumidas da produção de aminas e seus derivados (NEDER; LEAL, 2006)

Figura 7 - Representação idealizada da interface mineral/solução. (A) Surfactante catiônico adsorve individualmente, sem interações laterais entre suas cadeias hidrocarbônicas. (B) Formação de hemi-micelas através de interações laterais entre as cadeias hidrocarbônicas. (C) Formação de múltiplas camadas adsorvidas (Adaptado de Smith e Akhtar, 1976). .45

Figura 8 - Flotação de caulinita e hematita em função da concentração do amido de amido, utilizando Flotigam EDA $\left(1 \times 10^{-4} \mathrm{~mol} / \mathrm{L}\right)$ a um $\mathrm{pH}=10$ .49

Figura 9 - Superfície da caulinita em solução ácida (a) e solução alcalina (b). (YUEHUA ET AL., 2004)

Figura 10 - Estrutura cristalográfica da caulinita, (001) $\mathrm{SiO}^{4}$ e $(001) \mathrm{AlO}^{2}(\mathrm{OH}) 4$ (YUEHUA ET AL., 2004) 
Figura 11 - Formação do floculo de caulinita na presença de DDA e floculante (PAAM). (YUEHUA ET AL., 2004)

Figura 12 - Recuperação da flotação e potencial zeta da caulinita em função do pH usando CTAB (0,2Mm).(HU, JIANG E WANG, 2003)

Figura 13 - Ângulo de contato da caulinita, pirofilita e ilita em função do pH (HU; LIU; $X U, 2003)$ 55

Figura 14 - Ângulo de contato do diásporo, caulinita, pirofilita eilita com uma solução de 0,2 mM DDA em função do pH (HU; LIU; XU, 2003). 56

Figura 15 - Ângulo de contato do disporo, caulinita, pirofilita e ilita com uma solução de 0,2 mM de oleato em função do pH (HU; LIU; XU, 2003) 57

Figura 16 - Potencial zeta do diásporo, caulinita, pirofilita e ilita medida em soluções de 1 mM de KCL em função do pH (HU; LIU; XU, 2003) 58

Figura 17- Distribuição de tamanho de três amostras de caulinita. .59

Figura 18 - Recuperação de caulinita e feldspato em ensaios de flotação de bancada com KI (amostra com maior quantidade de finos) usando como coletor CPCI (KÖSTER et at.1992) 60

Figura 19 - Recuperação da caulinita e feldspato em ensaios de flotação com o coletor AMD para as três granulometrias da tabela 1 (KÖSTER et at.1992) 61

Figura 20 - Recuperações de caulinita e feldspato em ensaios de flotação de bancada com o coletor dodecilbenzenosulfonato de sódio (Amostras KI e KII) (KÖSTER et at.1992) 62

Figura 21 - Potencial zeta da caulinita em função do pH com coletores 12-4-12 e DTAB. (XIA et al. 2009) 63

Figura 22 - Potencial zeta da caulinita em função do pH com coletores BDDA e EDDA. (HUANG et al. 2013) .64 
Figura 23 - Principais leis da Bibliometria e seus focos de estudo (GUEDES E BORSCHIVER, sem data)

Figura 24 - Representação dos dados exportados do ScienceDirect e sua formatação em planilha Exel (elaboração própria).

Figura 25 - Representação dos dados exportados do ScienceDirect e sua formatação na planilha Exel para os artigos que estão de acordo com o objetivo da dissertação (elaboração própria)

Figura 26 - Planilha com a identificação de todos reagentes empregados nos artigos, siglas e nomes por extenso (elaboração própria) .73

Figura 27 - Planilha com os métodos, minerais e reagentes empregados em todos os artigos do estudo (elaboração própria). .74

Figura 28 - Planilha com as palavras-chave mais utilizadas nos artigos de flotação de caulinita (elaboração própria) .75

Figura 29: Citações pelo Scopus. .76

Figura 30: Planilha contendo as citações entre os 39 artigos estudados na análise bibliométrica, onde a marca verde sinaliza uma citação entre dois artigos (elaboração própria). .77

Figura 31: Planilha para verificar as recuperações dos coletores utilizados nos ensaios de flotação nos 39 artigos .78

Figura 32: Artigos sobre flotação de caulinita que são mais citados por artigos do mesmo tema (Elaboração própria) 101

Figura 33 - Fórmula molecular dos vinte sais de amônio quarternário 130 Figura 34 - Recuperação do mineral de caulinita na flotação com vinte diferentes sais de amônio quaternário (2×10-4 mol/L) (YUEHUA HU et al, 2012). 131 


\section{LISTA DE GRÁFICOS}

Gráfico 1 - Distribuição geográfica em porcentagem dos artigos produzidos por autores do mesmo país no período de 1992 a 2015 (elaboração própria). .82

Gráfico 2 - Distribuição geográfica em porcentagem dos artigos produzidos por autores de mais de um país no período de 1992 a 2015 (elaboração própria) .83

Gráfico 3- Evolução dos artigos produzidos no período de 1992 a 2015 (elaboração própria)

Gráfico 4 - Distribuição em porcentagem dos artigos produzidos por ano no período de 1992 a 2015 (elaboração própria) 85

Gráfico 5 - Quantidade de artigos por números de autores em porcentagem no período de 1992 a 2015 (elaboração própria) .87

Gráfico 6 - Número de artigos por número de páginas (Elaboração própria) .88 Gráfico 7 - Número de artigos por número de páginas em porcentagem (Elaboração própria) .89

Gráfico 8 - Número de artigos por periódicos (Elaboração própria). 90

Gráfico 9 - Quantidade de palavras-chave por artigo (Elaboração própria) 91

Gráfico 10 - Minerais citados nas palavras-chave dos 39 artigos e sua distribuição em porcentual (Elaboração própria) 93

Gráfico 11 - Palavras-chave mais frequentes nos 39 artigos (Elaboração própria)...94

Gráfico 12- Minerais envolvidos nos 39 artigos (Elaboração própria) .95

Gráfico 13 - Métodos mais utilizados nos artigos (Elaboração própria) .97

Gráfico 14: Artigos mais citados pelo Scopus (Elaboração própria). .98

Gráfico 15 - Linha do tempo das citações pelo Scopus (Elaboração própria). .99

Gráfico 16: Reagentes utilizados nos ensaios de flotação dos 39 artigos. 103 
Gráfico 17 - pH que concentra o maior valor de recuperação de caulinita dos coletores (Elaboração própria). 110

Gráfico 18 - Gráfico A dos coletores utilizados nos testes de flotação nos artigos da amostra (Elaboração própria).

Gráfico 19 - Gráfico B dos coletores utilizados nos testes de flotação nos artigos da amostra (Elaboração própria). 114

Gráfico 20 - Gráfico C dos coletores utilizados nos testes de flotação nos artigos da amostra (Elaboração própria) 


\section{LISTA DE TABELAS}

Tabela 1 - Nome e fórmula química dos principais coletores derivados de amina (NEDER, 2005).

Tabela 2- Distribuição geográfica dos artigos produzidos por autores do mesmo país no período de 1992 a 2015 (elaboração própria)

Tabela 3 - Distribuição geográfica dos artigos produzidos por autores filiados de mais de um país no período de 1992 a 2015 (elaboração própria)

Tabela 4 - Quantidade de artigos por números de autores .86

Tabela 5 - Minerais encontrados nas palavras-chave dos 39 artigos (Elaboração própria).

Tabela 6 - Nome químico ou comercio dos reagentes químicos utilizados nos 39 artigos por extenso e seus respectivas abreviações. 104

Tabela 7 - Nome dos reagentes químicos utilizados nos artigos 1 até 20 por pH de flotação 107

Tabela 8 - Nome dos reagentes químicos utilizados nos artigos 21 até 39 por pH de flotação 108

Tabela 9: Resultados dos resultados de recuperação nos testes de flotação para o coletor DTAC para o artigo de número 3 (Elaboração própria) 116

Tabela 10: Resultados dos resultados de recuperação nos testes de flotação para o coletor DTAC para o artigo de número 23 (Elaboração própria) 117

Tabela 11: Resultados dos resultados de recuperação nos testes de flotação para o coletor CTAC para o artigo de número 3 (Elaboração própria) 118

Tabela 12: Resultados dos resultados de recuperação nos testes de flotação para o coletor DTAB para o artigo de número 2 (Elaboração própria) 
Tabela 13: Resultados dos resultados de recuperação nos testes de flotação para o coletor DTAB para o artigo de número 19 (Elaboração própria) 120

Tabela 14: Resultados dos resultados de recuperação nos testes de flotação para o coletor AQ142 para o artigo de número 2 (Elaboração própria).

Tabela 15: Resultados dos resultados de recuperação nos testes de flotação para o coletor CTAB para o artigo de número 6 (Elaboração própria)

Tabela 16: Resultados dos resultados de recuperação nos testes de flotação para o coletor CTAB para o artigo de número 8 (Elaboração própria)

Tabela 17: Resultados dos resultados de recuperação nos testes de flotação para o coletor 12-4-12 mais amido para o artigo de número 14 (Elaboração própria) 122

Tabela 18: Resultados dos resultados de recuperação nos testes de flotação para o coletor 12-4-12 para o artigo de número 14 (Elaboração própria). 123

Tabela 19: Resultados dos resultados de recuperação nos testes de flotação para o coletor BDDA para o artigo de número 25 (Elaboração própria)

Tabela 20: Resultados dos resultados de recuperação nos testes de flotação para o coletor 12-4-12 para o artigo de número 34 (Elaboração própria).

Tabela 21: Resultados dos resultados de recuperação nos testes de flotação para o coletor 12-4-12 mais depressor para o artigo de número 34 (Elaboração própria).125 Tabela 22: Resultados dos resultados de recuperação nos testes de flotação para o coletor DDTA para o artigo de número 16 (Elaboração própria) 125

Tabela 23: Resultados dos resultados de recuperação nos testes de flotação para o coletor DDGS para o artigo de número 23 (Elaboração própria). 126

Tabela 24: Resultados dos resultados de recuperação nos testes de flotação para o coletor DDA para o artigo de número 25 (Elaboração própria) 
Tabela 25 - Recuperação na flotação do mineral de caulinita em três diferentes frações de tamanho em uma concentração de $4 \times 10^{-4} \mathrm{~mol} / \mathrm{L}$ de $103 \mathrm{C}$ para o artigo 33 (Elaboração própria).

Tabela 26 - Recuperação na flotação do mineral de caulinita em três diferentes frações de tamanho em uma concentração de $4 \times 10^{-4} \mathrm{~mol} / \mathrm{L}$ de TTAC (Artigo 33).129 Tabela 27: Resultados dos resultados de recuperação nos testes de flotação para o coletor Flotigam EDA para o artigo de número 2 (Elaboração própria). 132

Tabela 28: Resultados dos resultados de recuperação nos testes de flotação para o coletor EDA 3 para o artigo de número 10 (Elaboração própria).

Tabela 29: Resultados dos resultados de recuperação nos testes de flotação para o coletor DRN para os artigos de número 4,12 e 32 (Elaboração própria). 134

Tabela 30: Resultados dos resultados de recuperação nos testes de flotação para o coletor DEN para os artigos de número 4,12 e 32 (Elaboração própria) 135

Tabela 31: Resultados dos resultados de recuperação nos testes de flotação para o coletor DPN para os artigos de número 4,12 e 32 (Elaboração própria). 135

Tabela 32: Resultados dos resultados de recuperação nos testes de flotação para o coletor DBN para os artigos de número 4 e 12 (Elaboração própria). 136

Tabela 33: Resultados dos resultados de recuperação nos testes de flotação para o coletor PN para o artigo de número 15 (Elaboração própria) 136

Tabela 34: Resultados dos resultados de recuperação nos testes de flotação para o coletor DDA para o artigo de número 11 (Elaboração própria) 137

Tabela 35: Resultados dos resultados de recuperação nos testes de flotação para o coletor DDA mais APAM para o artigo de número 11 (Elaboração própria). 138

Tabela 36: Resultados dos resultados de recuperação nos testes de flotação para o coletor DC para o artigo de número 37 (Elaboração própria) 
Tabela 37: Resultados dos resultados de recuperação nos testes de flotação para o coletor DDA para o artigo de número 16 (Elaboração própria)

Tabela 38: Resultados dos resultados de recuperação nos testes de flotação para o coletor DDA para o artigo de número 5 (Elaboração própria)

Tabela 39: Resultados dos resultados de recuperação nos testes de flotação para o coletor DDA mais WMS para o artigo de número 5 (Elaboração própria)

Tabela 40: Resultados dos resultados de recuperação nos testes de flotação para o coletor DDA para o artigo de número 31 (Elaboração própria)

Tabela 41: Resultados dos resultados de recuperação nos testes de flotação para o coletor DDA mais ATNO para o artigo de número 31 (Elaboração própria).

Tabela 42: Resultados dos resultados de recuperação nos testes de flotação para o coletor DDA para o artigo de número 30 (Elaboração própria)

Tabela 43: Resultados dos resultados de recuperação nos testes de flotação para o coletor DDA mais DA-5 para o artigo de número 30 (Elaboração própria).

Tabela 44: Resultados dos resultados de recuperação nos testes de flotação para o coletor DDAC para o artigo de número 23 (Elaboração própria) 144

Tabela 45: Resultados dos resultados de recuperação nos testes de flotação para o coletor ADPA para o artigo de número 18 (Elaboração própria) 145

Tabela 46: Resultados dos resultados de recuperação nos testes de flotação para o coletor NHOD para o artigo de número 35 (Elaboração própria) 145

Tabela 47: Resultados dos resultados de recuperação nos testes de flotação para o coletor SAG8, SAG10 e SAG12 para o artigo de número 20 (Elaboração própria) 147 Tabela 48: Resultados dos resultados de recuperação nos testes de flotação para o coletor Oleato em três faixas granulométricas para o artigo de número 16 (Elaboração própria) 148 
Tabela 49: Resultados dos resultados de recuperação nos testes de flotação para o coletor SIPX em três faixas granulométricas para o artigo de número 7 (Elaboração própria). 149

Tabela 50: Resultados dos resultados de recuperação nos testes de flotação para o coletor HHO para o artigo de número 29 (Elaboração própria) 150

Tabela 51: Resultados dos resultados de recuperação nos testes de flotação para o coletor BBAB para o artigo de número 26 (Elaboração própria) 150 Tabela 52-Nome e informações de todos os artigos escolhidos para Análise Bibliométrica (elaboração própria). 169 


\section{SUMÁRIO}

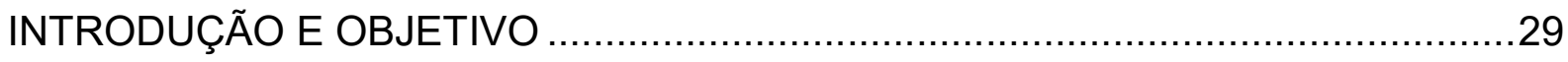

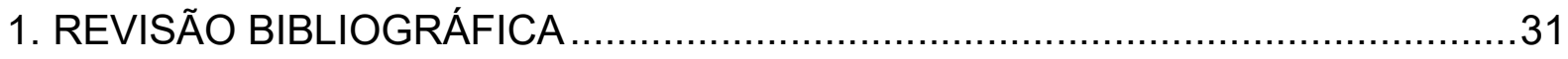

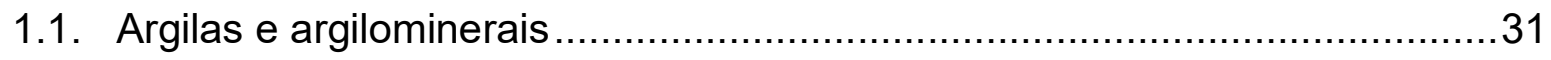

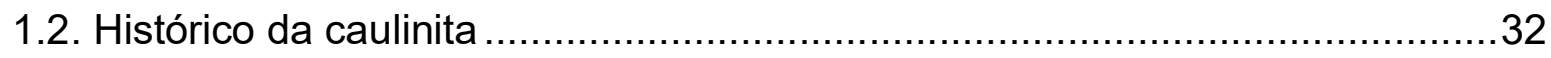

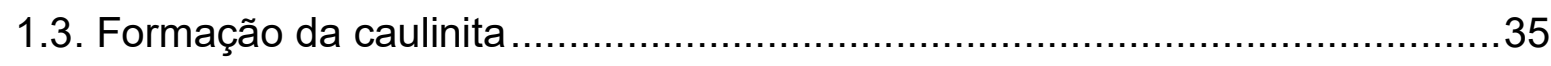

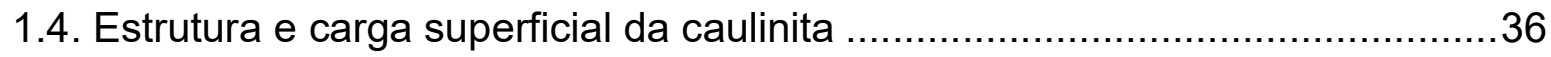

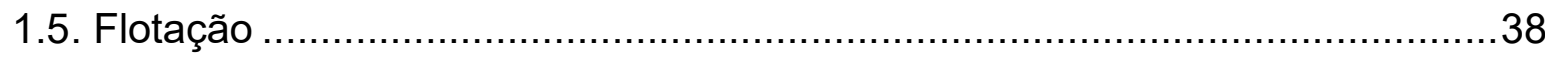

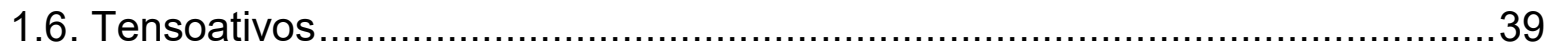

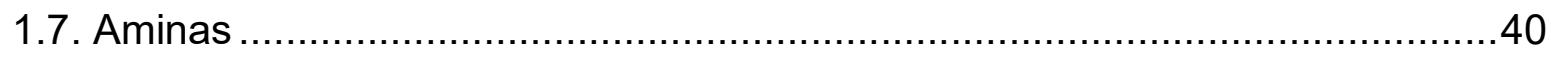

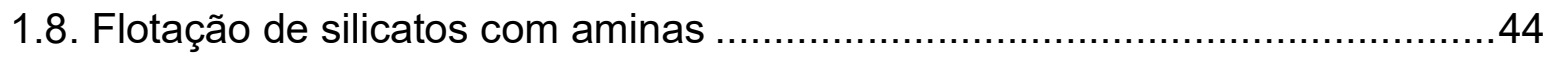

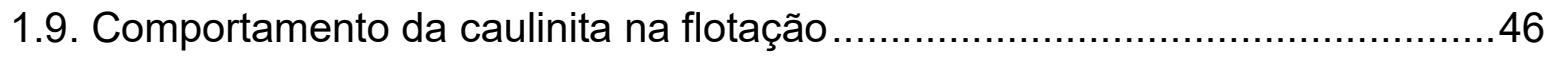

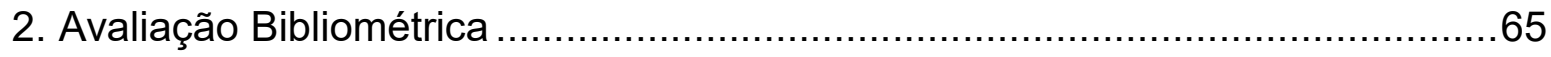

2. METODOLOGIA

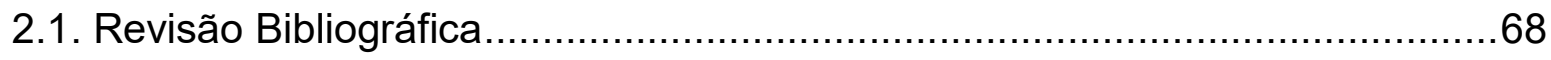

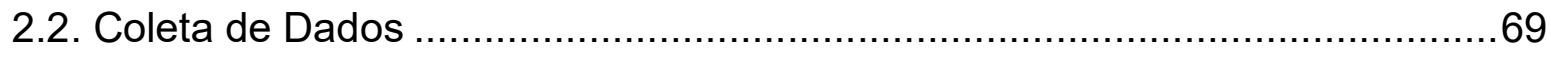

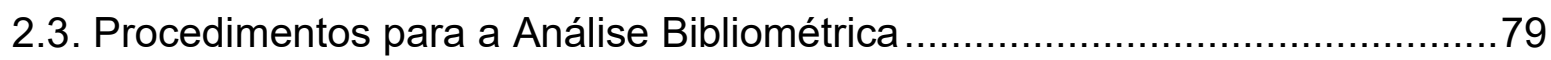

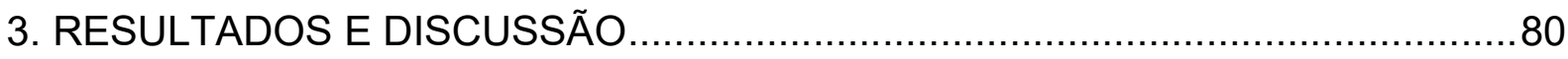


3.1 Informações sobre os artigos .80

3.2. Análise Geográfica .80

3.3. Análise temporal .84

3.4. Análise do número de autores por artigo .85

3.5. Análise dos artigos de acordo com o número de páginas .87

3.6. Análise dos artigos por: periódicos e classificação CAPES .89

3.7. Análise dos artigos através de palavras-chave. 91

3.8. Minerais envolvidos na flotação de caulinita .94

3.9. Análise dos métodos mais significativos utilizados nos artigos .96

3.10 Citações pelo Scopus 97

3.11 Citações dos 39 artigos da análise bibliométrica .99

3.12 Reagentes utilizados nos ensaios de flotação dos artigos 39 artigos 102

3.13. Nome dos reagentes químicos utilizados nos 39 artigos analisados. 103

3.14. Análise do pH de flotação 105

3.15 Recuperações dos coletores utilizados nos ensaios de flotação nos 39 artigos

3.15.1 DTAC - Cloreto de dodeciltrimetil amônio (Sal quaternário de amônio)....115

3.15.2 CTAC - Cloreto de cetiltrimetil amônio (Sal quaternário de amônio)

3.15.3 DTAB - Brometo de dodeciltrimetil amônio (Sal quaternário de amônio)..119

3.15.4 AQ142 -Tomamine (Sal quaternário de amônio) 120

3.15.5 CTAB - Brometo de cetiltrimetil amônio - sal de amônio quaternário...... .121 
3.15.6 BDDA ou 12-4-12 - Brometo de dimetildodecil amônio dissubstituído - Sal de amônio quaternário 122

3.15.7 DDTA- Sal de amônio (radical alquila) - Sal de amônio quaternário 125

3.15.8 DDGS - Sulfato de dodecilguanidina - Sal de amônio quaternário. 126

3.15.9 EDDA - Brometo dodecildimetil amônio - Sal de amônio quaternário 126

3.15.10 103C - Dodeciltrimetil amônio - Sal de amônio quaternário 127

3.15.11 TTAC - Cloreto de tetradeciltrimetil amônio - Sal de amônio quaternário128

3.15.12 Vinte diferentes sais de amônio quaternários (20Q) 129

3.15.13 Flotigam EDA - Éter-amina. 131

3.15.14 Flotigam EDA 3 - Éter-monoamina. 132

3.15.15 Flotigam 2835 (2L) - Éter-Diamina 133

3.15.16 Aminas terciárias 133

3.15.17 DDA - Acetato de dodecilamina - Amina primária 137

3.15.18 DC- Cloreto de dodecilamina - Amina primária 138

3.15.19 Dodecilamina - Amina primária 139

3.15.20 DDAC - Cloreto de dodecilamina - Amina primária 144

3.15.21 ADPA - N-(3-aminopropil)-dodecamida- Amida 144

3.15.22 NHOD - N-(6-(hidroxiamino)-6-oxo-hexil) decanamida- Amida 145

3.15.23 AENA N-(2-aminoetill)1 naftaleno acetamida - Amida 146

3.15.24 - Derivados de Ácidos Carboxílicos 146

3.15.25 Composto nitrogenado 147 
3.15.26 Oleato de sódio

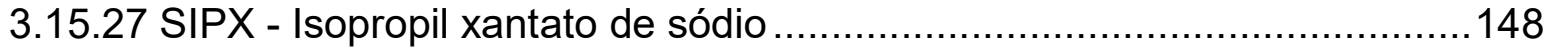

3.15.28 HHO - Hidrolisado de lavagem suína ................................................149

3.15.29 BBAB - Gemini surfactante de trisiloxano butano-1,4-bis (dimetil- (3- (3aminopropil trisiloxano-3-il) -propil-etil) -amónio) …......................................150

CONCLUSÃO

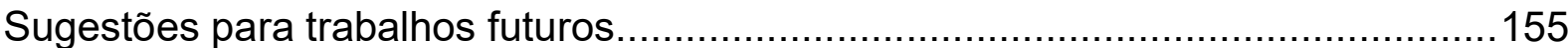

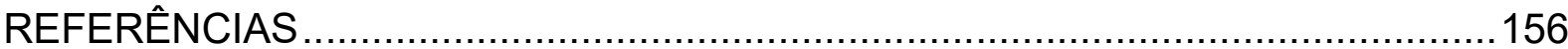

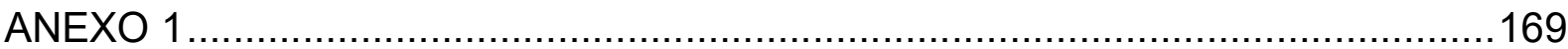




\section{INTRODUÇÃO E OBJETIVO}

A caulinita é um argilomineral composto de silicatos hidratados de alumínio, cuja composição química é expressa pela fórmula $\mathrm{Al}_{4}\left(\mathrm{Si}_{4} \mathrm{O}_{10}\right)(\mathrm{OH})_{8}$. Embora sua principal aplicação seja na indústria de papel, atualmente a grande parte dos estudos que envolvem a flotação de caulinita são desenvolvidos na China onde o mineral é tratado como rejeito dos depósitos bauxiticos.

Os artigos levantados sobre o assunto na literatura mostram que a flotação é realizada em diferentes condições operacionais e na presença de diversos tensoativos, normalmente coletores catiônicos pertencentes da classe das aminas. Outra condição operacional importante é o pH de flotação. No Brasil a flotação de caulinita é realizada em meio alcalino e segue o modelo eletrostático, ou seja, a adsorção das aminas sobre a superfície dos silicatos ocorre acima do seu Ponto isoelétrico (IEP) quando ocorre excesso de cargas elétricas negativas na interface silicato/solução. Embora exista um consenso geral que o modelo eletrostático seja o principal mecanismo de adsorção de aminas graxas em silicatos, na flotação de caulinita na China, o mineral apresenta sua melhor condição de flotação em meio ácido. Autores como Hu, Jiang e Wang (2003) explicam que esse comportamento anômalo na flotação em pH ácido é atribuido ao comportamento de agregação ou dispersão da caulinita e também à natureza das cargas dos planos basais e nas bordas.

Buscando trazer uma contribuição à flotação de caulinita, o presente trabalho foi desenvolvido com o objetivo de fazer uma avaliação bibliométrica sobre a flotação de caulinita. Todos os artigos foram publicados em periódicos internacionais no período de 1992 a 2015 e pesquisados no banco de dados SciVerse ScienceDirect, pertencente à editora Elsevier.

A importância de estudos de natureza bibliométrica é dispor de trabalhos que nos informem sobre as metodologias de pesquisas e resultados das publicações de uma determinada área científica assim como número de autores, países ou revistas 
onde esses são publicados. Estudos desse caráter permitem avaliar a qualidade e a quantidade do que está sendo produzido e são uma ferramenta importante no diagnóstico real das potencialidades das publicações de uma determinada área de assunto (ARAÚJO, 2006; VIANNA, 2012; GUEDES e BORSCHIVER, sem data). 


\section{REVISÃO BIBLIOGRÁFICA}

\subsection{Argilas e argilominerais}

As argilas são utilizadas pelo homem desde antiguidade a nas mais diversas aplicações na produção de utensílios domésticos. São também largamente utilizados na fabricação de produtos cerâmicos, porcelanas e outros (SANTOS,1992). As argilas são elementos componentes de uma grande parte dos solos e são encontradas no estado puro ou em depósitos, em seu ambiente de formação e em ambientes naturais.

De acordo com Coelho (2006) os argilominerais são aluminossilicatos hidratados encontrados na natureza, podendo ser também silicatos de ferro ou magnésio hidratados, com estruturas cristalinas em camadas. Pertencem ao grupo dos filossilicatos e são constituídos por folhas contínuas de tetraedros de silício $\left(\mathrm{SiO}_{4}\right)^{-4}$ ordenados de forma hexagonal, condensados com folhas octaédricas de hidróxidos de metais tri e divalentes e com granulometria inferior a $2 \mu \mathrm{m}$. O autor ainda cita que os argilominerais são muitas vezes chamados "silicatos em camadas" ("layer silicates") e "filossilicatos" e que alguns argilominerais podem conter uma fração com dimensões na faixa de 1 a $100 \mathrm{~nm}$.

As argilas são formadas pelos elementos silício ( $\mathrm{Si}$ ), alumínio (Al) e oxigênio $(\mathrm{O})$, e outros em menores proporções como magnésio $(\mathrm{Mg})$, ferro $(\mathrm{Fe})$ e cálcio $(\mathrm{Ca})$. Os átomos organizados desses elementos formam o retículo cristalino que vai originar as argilas. Durante a formação dos cristais pode ocorrer a substituição do tetraedro por outros átomos, como alumínio e ferro, assim também do alumínio dos octaedros por magnésio, cálcio, ferro e outros. Essas substituições são responsáveis pelo aparecimento de uma carga elétrica, normalmente negativa, na superfície das plaquetas (Chagas, sem data).

As argilas possuem uma grande afinidade pela água, chamada de hidrofilicidade. Essa afinidade é decorrente das cargas de superfície. O mineral com carga negativa atrai íons positivos que se ligam as moléculas de água. Essa primeira 
camada de água na superfície do cristal não "escoa"; a esse fenômeno dá-se o nome de dupla camada elétrica (Figura 1) (CHAGAS, sem data).

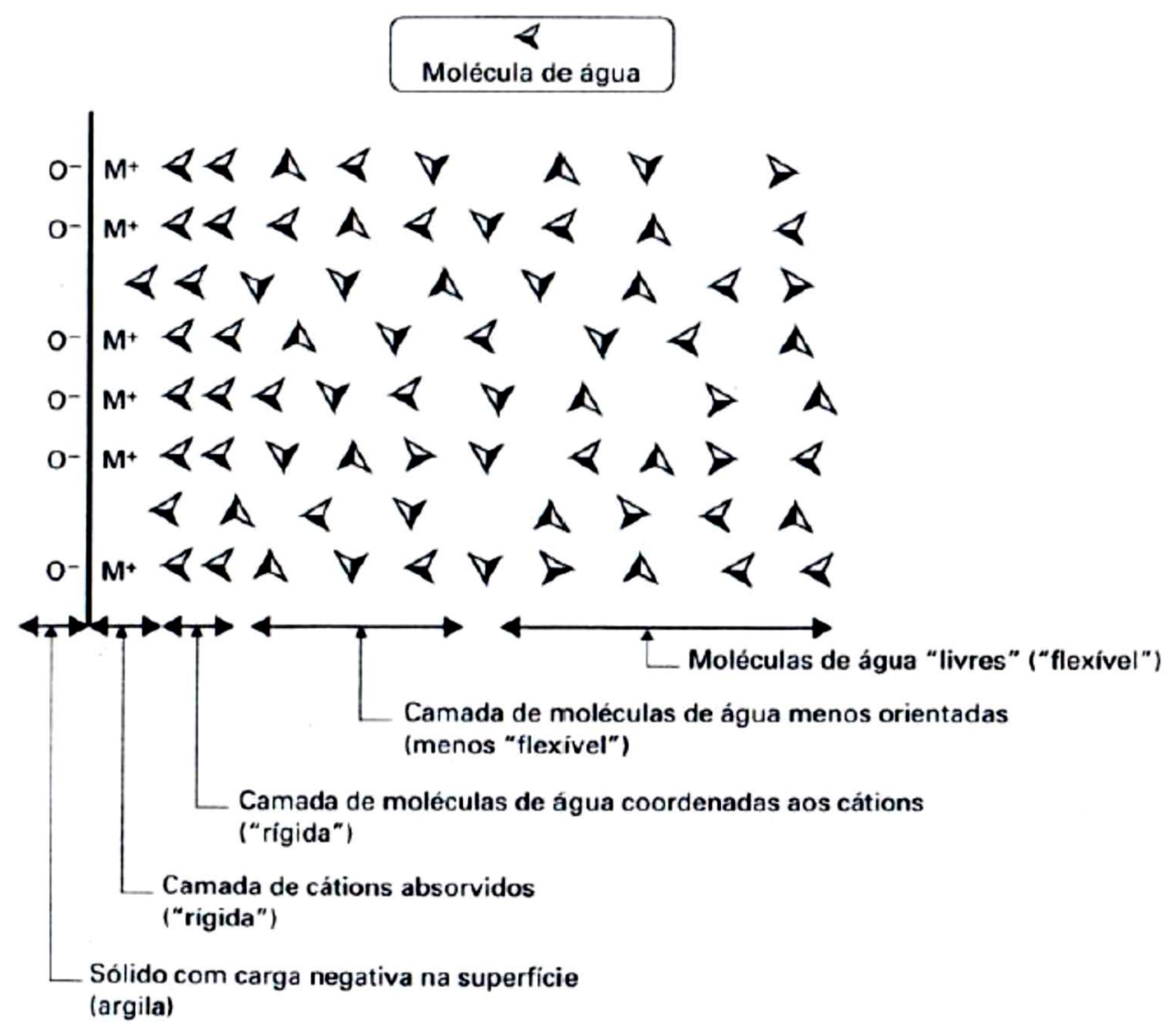

Figura 1 - Dupla camada elétrica das argilas (CHAGAS, sem data)

\subsection{Histórico da caulinita}

O caulim, rocha que contém a caulinita, é considerado um dos minerais mais importantes e abundantes no mundo. Sua utilização é bastante antiga e extensa, atualmente é usado na indústria de papel, cerâmicas, tintas, plástico, borracha e na produção de catalisadores (MURRAY, 1990). De acordo com Dana e Hurlbut (1959) a termologia caulim surgiu da palavra chinesa Kauling que significa cume alto ou coluna alta e se refere a uma região montanhosa no norte da China onde se obtém o minério. 
A caulinita é empregada há séculos. No ano de 800 , o mineral já era utilizado na produção de porcelana na província chinesa Kiangsi. No período de 998 até 1023 o imperador Ching-Tsung monopolizou a fabricação das cerâmicas e os objetos eram todos reservados para a família imperial. Nessa época, as porcelanas eram feitas a partir de rochas pulverizadas que sofreram um processo de intemperismo ou alterações hidrotermais. Essas rochas continham caulim, quartzo, feldespato e muscovita e eram trazidas de diversos lugares na China. Na metade da Dinastia Yuan que durou do ano de 1200 até 1368, a mistura de caulim com feldspato tornou-se ainda mais comum (CHEN,LIN e ZHENG, 1997). De acordo com Chagas (sem data) o segredo da porcelana chinesa era devido ao tratamento que era aplicado no caulim com urina. Essa contêm substâncias como uréia e sais de amônio que são retidas na superfície da argila e que provocam o afastamento das placas microcristalinas dessa, tornando o material mais plástico.

A primeira aparição do termo kauling earth ocorreu na China em um documento da Dinastia Ming no ano de 1604. O mesmo termo também foi encontrado na History of Fouliang-Hsien do ano de 1682 no livro Ching-teh-chien Tau Lu (Figura 2). A utilização dos caulins extraídos das minas de Kauling para produção de cerâmicas é registrada desde o século XVII (CHEN,LIN e ZHENG, 1997). 


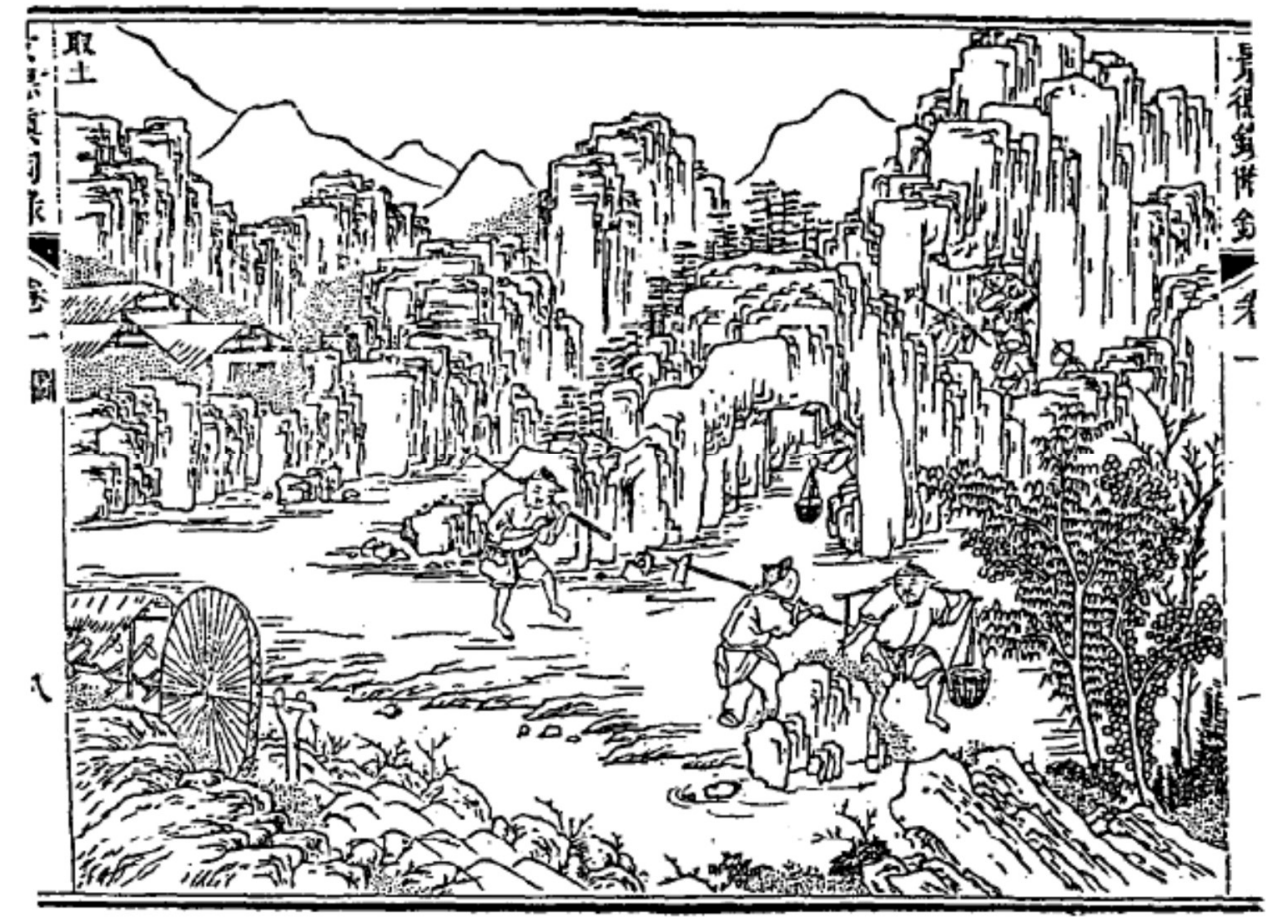

Figura 2 - Desenho de uma pedreira de caulim localizada em Kauling (CHEN,LIN e ZHENG, 1997).

Os séculos XVII e XVIII foram considerados a época dourada para a porcelana em Chingtehchin. Após esse período, a qualidade do material oferecido para as indústrias de cerâmicas fez com que o mercado tivesse seus momentos mais e menos favoráveis. Além disso, o esgotamento de alguns depósitos ou a proibição da mineração pelo governo local contribuiu para esse momento de crise (CHEN,LIN e ZHENG, 1997).

De acordo com Bergaya, Theng e Lagaly (2006) a mina de Kiangsi foi explorada até 1964 quando ocorreu seu completo esgotamento.

Por volta do ano de 1712 o caulim foi apresentado à sociedade europeia através de um missionário jesuíta chamado Père d’Ėntrecolles. Já o termo caulinita que se refere à espécie mineral contida no caulim foi proposto por Johnsone Blake só no ano de 1867. (CHEN,LIN e ZHENG, 1997). Ross e Kerr no ano de 1930 difundiram o termo "caulinita" através do estudo denominado The kaolin minerals (Chen et al, 1997 apud Rodrigues, 2009). 
Conforme Silva (2003) até o século XIX o caulim foi usado quase que exclusivamente na indústria da cerâmica. Já na década de 1880 do referido século a descoberta da utilização do caulim como carga de papel, alterou-se substancialmente o panorama da sua aplicação. No século XX o caulim começou a ser utilizado na cobertura ou revestimento do papel e imediatamente antes da $1^{\circ}$ Guerra Mundial, $75 \%$ da sua produção era destinada à indústria de papel.

\subsection{Formação da caulinita}

Conforme Gomes (1988), de acordo com a sua gênese os minerais argilosos podem ser divididos em quatro grupos de materiais que servem de base para sua formação. O primeiro grupo é dos minerais primários que são: tectossilicatos, inossilicatos, filossicatos e o vidro vulcânico. O segundo grupo engloba os minerais argilosos pré-existentes. O terceiro grupo é de suspensões coloidais que incluem géis e, por último, o quarto grupo que são os íons em solução aquosa.

Os materiais supra citados proporcionam a formação de minerais argilosos que são classificados em três formas: os minerais de neoformação que são os formados pela primeira vez; os minerais argilosos transformados que são resultantes de modificações físicas, químicas e mineralógicas em minerais argilosos pré-existentes; minerais argilosos herdados que são resultantes da divisão física com eventual mais ligeira alteração química e estrutural de minerais argilosos pré-existentes (GOMES, 1988).

O mineral caulinita de neoformação ocorre em ambientes que concentram grandes quantidades de chuvas, boas drenagens e em solos ácidos (presença de rochas ácidas que são ricas em potássio e sódio e facilitam o processo de caulinização). A meterorização ocorre normalmente na presença de águas ácidas, e o seu processo retira cálcio, magnésio, ferro, sódio e potássio e é por isso que a caulinita é frequente nas áreas de climas temperados e de florestas (GOMES, 1988). 
Conforme o autor, já nos climas tropicais onde o solo é neutro, também ocorre formação de depósitos com o mineral caulinita. Esse fenômeno acontece devido as elevadas temperaturas e precipitações contantes. Apesar do solo ser neutro devido à oxidação rápida da matéria orgânica cuja acumulação não é facilitada, a caulinita é abundante. Já em solos ácidos em climas tropicais não há ocorrências da caulinita. $A$ caulinita também ocorre associada à mica argilosa ou a minerais expansivos nas alterações argilíticas através do processo hidrotermal (GOMES, 1988).

Gomes (1988) ainda cita que a caulinita pode ocorrer em depósitos lacustres, fluviais, estuarinos, lagunares e marinhos como mineral herdado. A formação ocorre via líquida ou gasosa de locais mais ou menos distantes onde ela havia sido neoformada. A última formação é pelo processo de transformação onde a caulinita é transformada a partir de outros minerais argilosos.

\subsection{Estrutura e carga superficial da caulinita}

A caulinita é um argilomineral composto de silicatos hidratados de alumínio (LUZ,1993). Mineralogicamente pertence à classe dos silicatos, no grupo dos filossilicatos (DANA E HURLBUT,1974). A caulinita tem uma estrutura laminar de silicatos com duas camadas, expressa pela fórmula química $\mathrm{Al}_{2}\left(\mathrm{Si}_{2} \mathrm{O}_{5}\right)(\mathrm{OH})_{4}$, onde a camada tetraédrica de sílica é representada pela $\left(\mathrm{Si}_{2} \mathrm{OH}\right)^{2-}$ neutralizada eletricamente por uma camada adjacente de $\left[\mathrm{Al}_{2}(\mathrm{OH})_{4}\right]^{2+}(\mathrm{CALLISTER}$ E RETHWISCH, 2003).

Gomes (1988) ainda descreve que cada camada estrutural da caulinita é constituída pela associação duma folha tetraédrica de sílica com uma folha octaédrica de gibsita ou com uma folha octaédrica de brucita e que, em média, um cristal de caulinita apresenta de 40 a 50 camadas estruturais (Figura 3). 

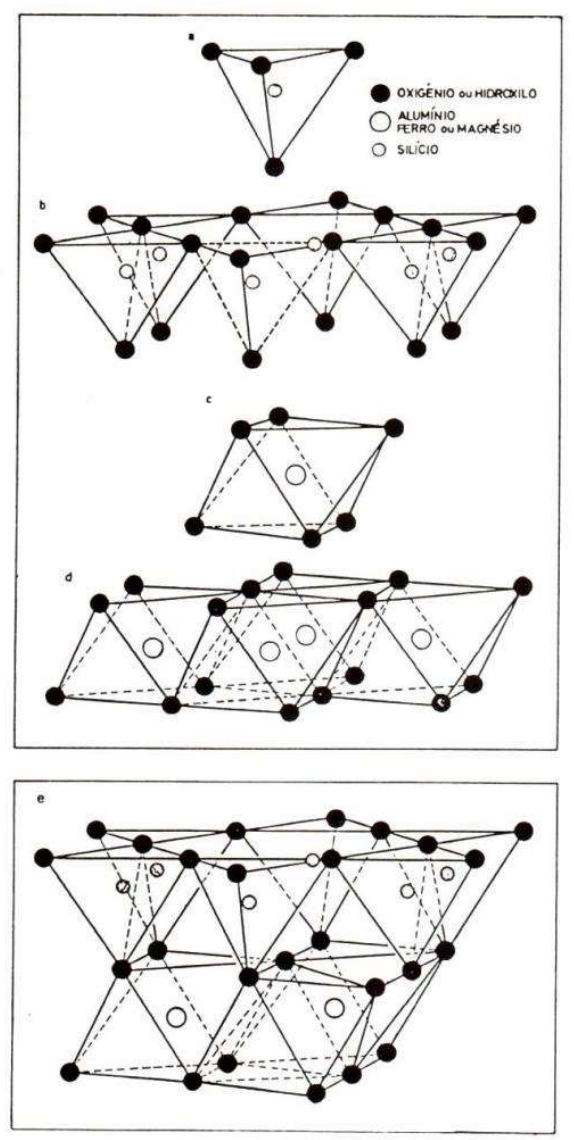

Figura 3 - a - Tetraedro de sílica; b - folha tetraédrica; c - octaedro em que o átomo coordenado pode ser Al, Fe ou Mg; d - folha octaédrica; e - modelo esquemático da camada estrutural básica da caulinita (GOMES, 1988)

De acordo com Gomes (1988), a caulinita é composta quimicamente por 38,9\% de $\mathrm{Al}_{2} \mathrm{O}_{3}, 46,3 \%$ de $\mathrm{SiO}_{2}$ e $13,9 \%$ de $\mathrm{H}_{2} \mathrm{O}$, onde os oxigênios das folhas tetraédricas apontam para as folhas octaédricas que situam-se em um plano comum com oxigênio (O) e hidroxila $(\mathrm{OH})$ desta folha e só $2 / 3$ das posições catiônicas coordenadas estão preenchidas por Al (dioctaédrico).

Chaves (2009) explica que quando os tetraedros-octaedros da caulinita são rompidos geram superfícies hidrofílicas nas placas que estavam conectadas via ligação de hidrogênio assim como nas bordas, onde as ligações eram de silício- 
oxigênio. Essas superfícies hidrofílicas levam a caulinita apresentar uma boa flotabilidade com coletores catiônicos e aniônicos acima do seu ponto isoelétrico (IEP).

Hu e Liu (2003) e Köster et al (1992) mostram que a caulinita adquire carga através de substituições isomórficas de $\mathrm{Si}^{4+}$ por $\mathrm{Al}^{3+}$ no plano basal, o que acarreta uma constante carga estrutural negativa nesses planos. Rodrigues (2009) completa explicando que a área superficial do mineral nos planos basais é bem maior que nos planos de borda e isso resultada em uma carga estrutural negativa para toda a partícula.

\subsection{Flotação}

Flotação é uma operação unitária de separação no tratamento de minério feito numa suspensão em água denominada polpa. Com partículas de uma faixa granulométrica entre $1 \mathrm{~mm}$ e $5 \mu \mathrm{m}$, esse processo de separação é aplicado a partículas sólidas e explora diferenças nas características de superfície entre as várias espécies presentes. Os fundamentos das técnicas de flotação estão no campo da ciência conhecido como "Físico-Química das interfaces", "Química de Superfície”, "Química das Interfaces" ou "Propriedades das Interfaces" (CHAVES, 2009).

No processo de flotação, a partícula hidrofóbica de uma dada espécie mineral que se deseja flotar se prende em um número suficiente de bolhas, a densidade do conjunto partícula-bolha torna-se menor que a do fluído, e percorre um trajeto vertical até a superfície. Na superfície da célula de flotação essa partícula "flotada" fica presa na espuma e é coletada. As demais partículas hidrofílicas de espécies minerais diferentes mantém sua rota inalterada (LUZ; SAMPAIO; FRANÇA, 2010).

Conforme Chaves (2009) a seletividade do processo de flotação consiste no grau de hidrofobicidade da superfície de diferentes espécies minerais. A hidrofobicidade está associada ao grau de molhabilidade. Partículas mais hidrofóbicas, têm menor afinidade com as moléculas da água; o contrário acontece para as partículas hidrofílicas. 
Para que o caráter hidrofóbico seja induzido nas partículas de minerais naturalmente hidrofílicos (sulfetos, óxidos, silicatos, sais semi-solúveis e sais solúveis), faz-se necessário utilizar surfactantes, isto é, moléculas dotadas de um grupo funcional orgânico de caráter polar acoplado a uma cadeia hidrocarbônica. A adsorção de surfactantes na superfície de partículas hidrofílicas é capaz de nelas induzir o caráter hidrofóbico. Na literatura técnica, os surfactantes que induzem a hidrofobicidade em minerais que se deseja flotar, são chamados de agentes coletores (LEJA, 1982).

Em muitos casos para se alcançar a seletividade na flotação, se faz necessário o uso de modificadores ou reguladores que são substâncias orgânicas ou inorgânicas que ajustam diversas características na flotação, como: $\mathrm{pH}$, Eh, dispersão das partículas na polpa, ativação da superfície do mineral (para facilitar e tornar mais seletiva a ação do coletor), e os depressores (que têm a função de tornar um ou mais minerais imunes a ação do coletor) (CHAVES, 2009).

\subsection{Tensoativos}

Tensoativos são substâncias com estrutura molecular que possuem uma parte polar ou hidrofílica (afinidade com a água) e uma parte apolar ou hidrofóbica (aversão à água) (Figura 4). A primeira parte normalmente é composta por um hidrocarboneto e a segunda por uma parte iônica. Tensoativos podem ser considerados também como sendo compostos que alteram a tensão superficial de dois meios (NEDER, 2005).

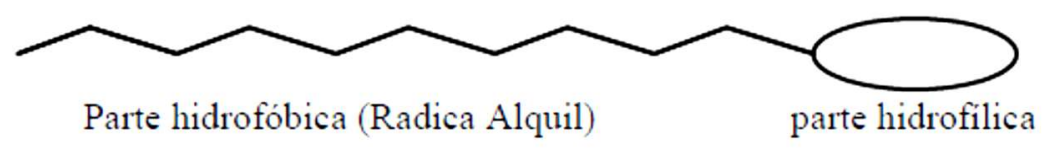

Figura 4 - Molécula de um tensoativo, parte hidrofóbica (polar) e parte hidrofílica (apolar) (Surfactants in Consumers Products, Apud NEDER, 2005) 
Conforme Neder (2005), a carga elétrica da parte hidrofílica e a forma molecular da cadeia carbônica da parte hidrofóbica, o arranjo do tensoativo permite que se tenham diferentes combinações gerando produtos distintos e de propriedades únicas. Desta forma, classificam-se os coletores como:

- Catiônicos: tensoativo cuja parte polar é carregada positivamente quando em uma solução aquosa, como: Aminas primárias e secundárias, sais de amônio quartanário, éter aminas e éter diaminas. Os surfactantes catiônicos serão os mais abordados nesse trabalho.

- Aniônicos: tensoativo que a parte polar é carregada negativamente quando em uma solução aquosa. Exemplo: Xantatos e os sais derivados de ácidos graxos.

- Não lônicos: tensoativos com a parte polar sem carga quando em soluções aquosas. Exemplo os etoxilados: Aquil fenóis, alcoóis, ácidos graxos e as aminas.

- Anfotéricos: Tensoativos que possuem dois grupos funcionais na mesma molécula. A carga desta molécula em soluções aquosas é regida pelo $\mathrm{pH}$ do meio. Exemplo os aminoácidos: Propionatos e sarcosinatos.

\subsection{Aminas}

Neder (2005) produziu um trabalho de caráter fundamental caracterizando as aminas graxas e seus derivados na flotação de minérios brasileiros, à vista disso o trabalho será a base principal desse capitulo. Segundo o Neder (2005) aminas graxas são um composto derivado da amônia $\left(\mathrm{NH}_{3}\right)$, alifáticos, cujas matérias-primas principais são óleos ou gorduras, saturadas ou não, classificando-se como primárias, secundárias ou terciárias (Figura 5) e que possuem cadeia carbônica com um número par de átomos de carbonos variando entre 8 e 22. Essas cadeias longas são encontradas sob a forma de triglicéridios. A termologia amina primária, secundária e terciária é referente à quantidade de átomos hidrogênio da amônia que foram substituídos por grupos alquil. Onde os radicais R, R', R" são cadeias carbônicas de 
diferentes tamanhos e distintos graus de saturação, podendo ser distintos uma da outra ou completamente iguais entre si (Apud. NEDER, 2005).<smiles>[1H]N</smiles>

Amônia<smiles>[R][Y][H]</smiles>

Amina primária<smiles>[R]N([R])[R]</smiles>

Amina secundária<smiles></smiles>

Amina terciária<smiles>[R][N+]([R])([R])[R7]</smiles>

Quaternário de amônio

Figura 5 - Classificação das aminas (Neder, 2005)

As aminas para flotação formadas por radicais alquil, só são tensoativos eficientes se a cadeia carbônica for superior a 6 carbonos. Aminas com comprimento de cadeia inferior a 6 carbonos não são consideradas graxas e apresentam um comportamento anfifílico, ou seja, a molécula não apresenta uma parte polar e hidrofílica e outra apolar e hidrofóbica. De acordo com Neder (2005) quando os grupos alquil tem 6 ou mais carbonos, e se usa o termo graxo, a molécula possui uma parte oleosa hidrofóbica e está ligada ao nitrogênio, possui um par de elétrons não compartilhados na sua camada de valência (característica iônica). A molécula pode ser de origem animal, vegetal, mineral.

Mundialmente, as aminas graxas são mais produzidas à base de soja; já no Brasil o graxo é derivado do sebo animal. As aminas graxas também podem ser produzidas através de alcoóis graxos que podem ter sua origem nos ácidos. A figura 6 apresenta o fluxograma com a rota de produção das aminas e seus derivados (Apud. NEDER, 2005). 


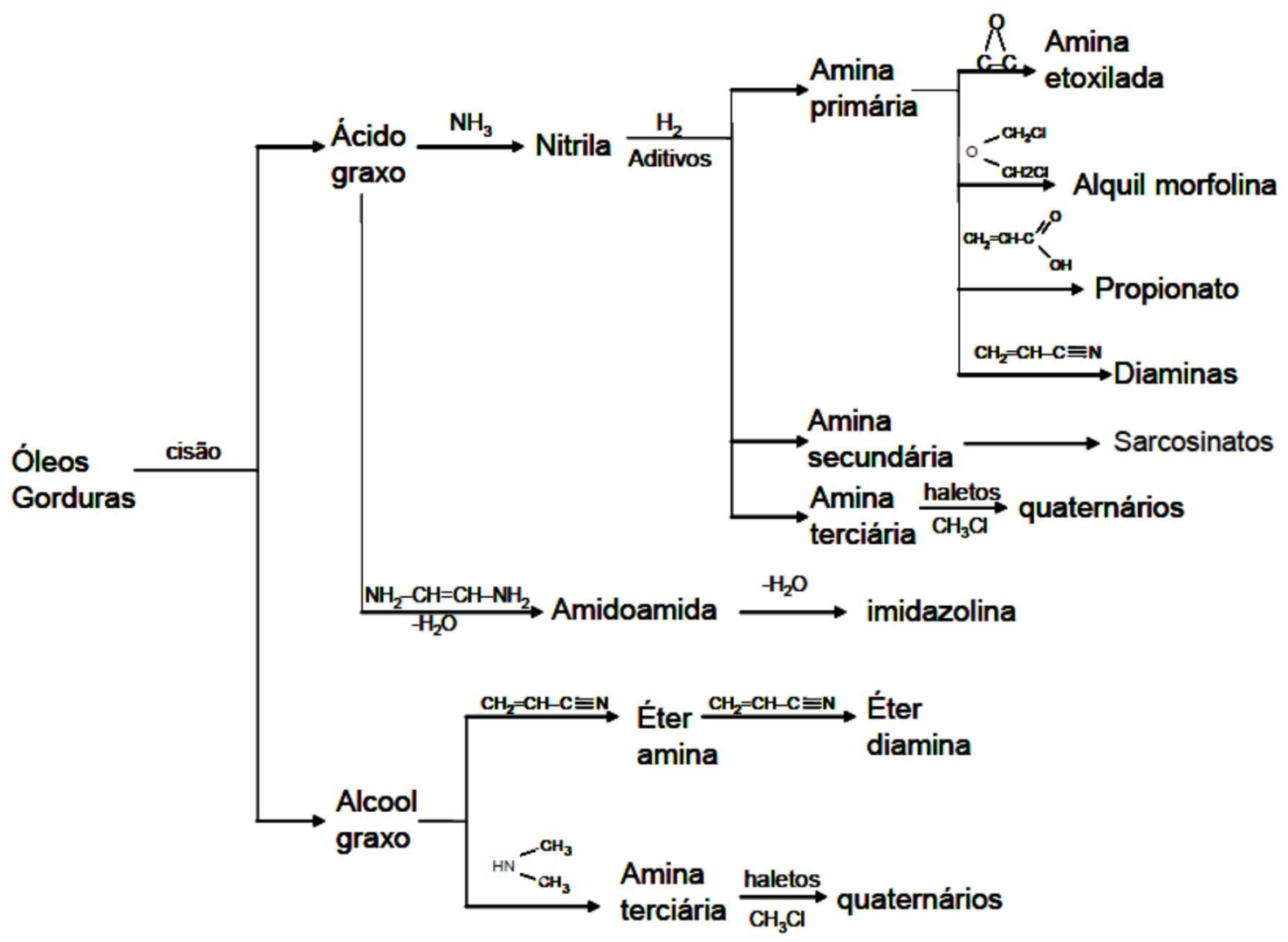

Figura 6 - Fluxograma com as rotas resumidas da produção de aminas e seus derivados (NEDER; LEAL, 2006)

$\mathrm{Na}$ tabela 1 é apresentada a estrutura química dos principais coletores derivados de aminas. 
Tabela 1 - Nome e fórmula química dos principais coletores derivados de amina (NEDER, 2005).

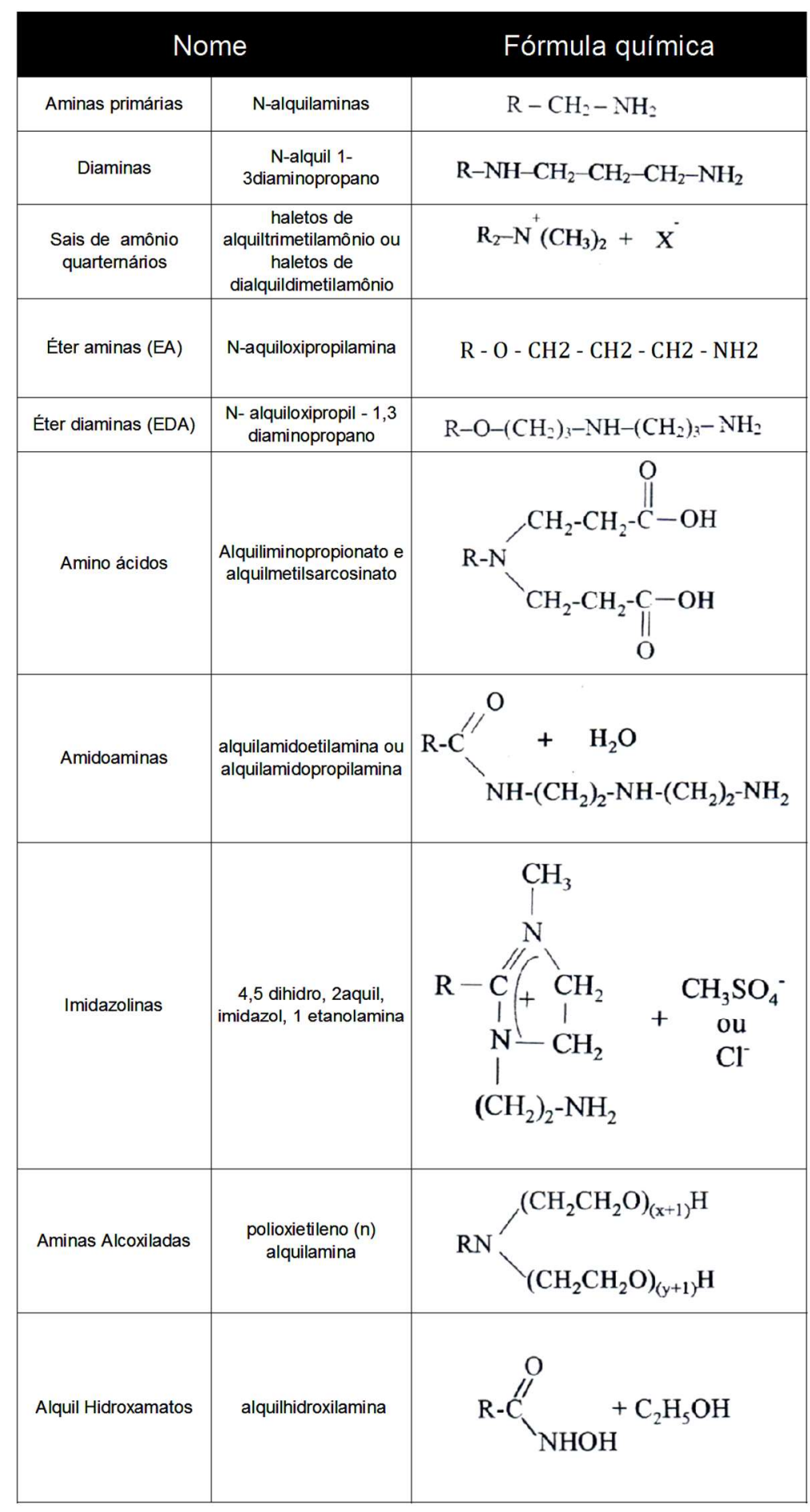




\subsection{Flotação de silicatos com aminas}

Em todo o mundo, a flotação de silicatos tem sido conduzida invariavelmente com aminas de cadeia longa ( $\mathrm{C} 12-\mathrm{C} 18)$, mais particularmente com sais produzidos a partir da neutralização de aminas primárias com ácidos fracos. Tais produtos apresentam relativamente alta solubilidade em meio aquoso, facilitando sua ação como agente coletor (MILLER et al, 2007). Conforme Rodrigues (2009) sua atividade superficial é afetada pela predominância da espécie iônica ou molecular, sendo que, na grande maioria das vezes, a ação coletora é exercida pela forma iônica.

A interação entre aminas graxas e silicatos tem sido exaustivamente estudada por métodos indiretos, isto é, através de medidas de ângulo de contato, potencial zeta, densidade de adsorção, resposta à microflotação, isotermas de adsorção, espectroscopia no infravermelho, espectrômetro de fotoelétrons excitados por raios- $X$ (XPS) e outras. Existe consenso geral de que o mecanismo de adsorção de aminas graxas em silicatos depende do $\mathrm{pH}$ do meio (CHAVES,2009).

A adsorção das aminas sobre a superfície dos silicatos ocorre acima do seu IEP, quando ocorre excesso de cargas elétricas negativas na interface silicato/solução, favorecendo atração eletrostática entre o coletor catiônico e a superfície mineral. Tal mecanismo constitui a base racional para um modelo de adsorção que foi inicialmente apresentado por Gaudin e posteriormente aprimorado por Fuerstenau e Somasundaran (GAUDIN e FUERSTENAU, 1955; FUERSTENAU, 1957; FUERSTENAU et al, 1964; SMITH e AKHTAR, 1976; SOMASUNDARAN et al, 2007). Tal modelo pode ser visualizado através da Figura 7. 
(A)

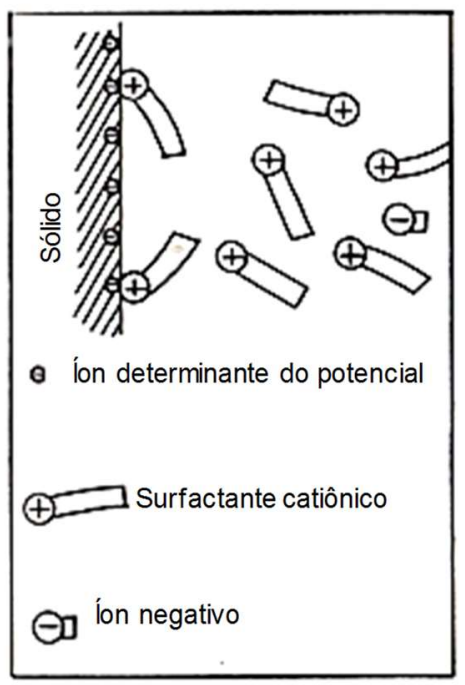

(B)

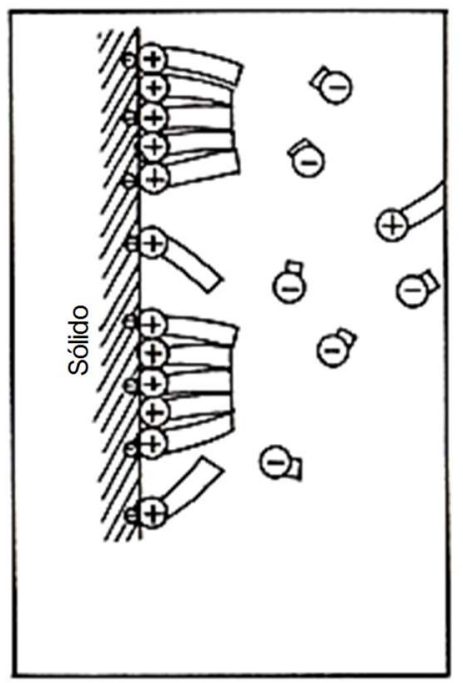

(C)

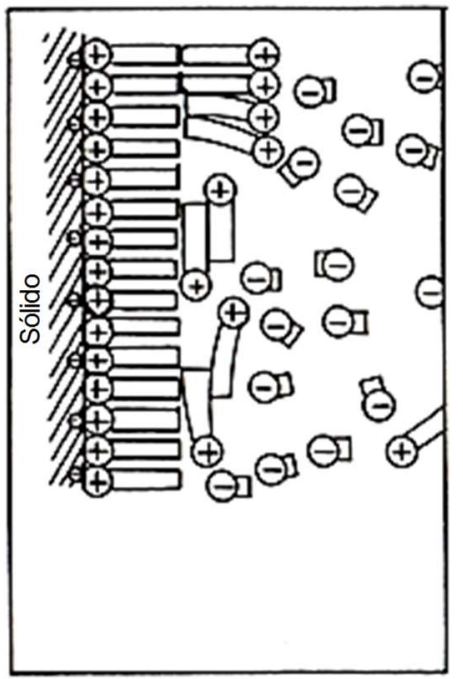

Figura 7 - Representação idealizada da interface mineral/solução. (A) Surfactante catiônico adsorve individualmente, sem interações laterais entre suas cadeias hidrocarbônicas. (B) Formação de hemi-micelas através de interações laterais entre as cadeias hidrocarbônicas. (C) Formação de múltiplas camadas adsorvidas (Adaptado de Smith e Akhtar, 1976).

De acordo com o modelo de Gaudin-Fuerstenau-Somasundaran, as espécies coletoras de carga positiva apresentam o seguinte comportamento (VIDYADHAR et al, 2002):

$\rightarrow$ Muito abaixo de sua concentração micelar crítica (CMC), as espécies catiônicas coletoras realizam adsorção física (eletrostática) na interface quartzo/solução. Elas são mantidas dentro da camada de Stern como contra-íons individuais que se comportam de modo muito semelhante a eletrólitos indiferentes. Tal comportamento é ilustrado na Figura 7-A;

$\rightarrow$ Quando a concentração das espécies coletoras na dupla camada atinge certo valor denominado de concentração hemi-micelar crítica $(\mathrm{CHC})$, a repulsão eletrostática entre as cabeças polares positivamente carregadas das espécies coletoras se torna menos intensa do que as interações atrativas entre as cadeias 
hidrocarbônicas, ocasionando a formação de agregados bidimensionais chamados de hemi-micelas (Figura 7-B). Neste ponto, curvas de adsorção apresentam um salto na quantidade de coletor que se adsorve na interface mineral/solução, o sinal do potencial zeta das partículas muda de negativo para positivo e um acentuado aumento na flotabilidade das partículas minerais é observado.

$\rightarrow$ Formação de multicamadas de amina na interface mineral/solução (Figura 7-C) ocorre quando a concentração de coletor atinge níveis próximos aos da concentração micelar crítica. Tal situação favorece o decréscimo da hidrofobicidade do mineral e, em decorrência, resposta à flotação também diminuirá.

O modelo postulado por Gaudin-Fuerstenau-Somasundaran traz implícitas duas premissas muito importantes (FUERSTENAU et al, 1964):

$\rightarrow$ As cabeças polares dos coletores nas hemi-micelas estão direcionadas para a superfície mineral e as respectivas cadeias hidrocarbônicas encontram-se orientadas em direção à solução;

$\rightarrow$ O mecanismo de formação de hemi-micelas na interface mineral/solução é análogo ao da formação de micelas no seio da solução. Devido à carga negativa dos silicatos, a concentração de coletor dentro da dupla camada é mais alta do que no seio da solução, fazendo com que se atinja a concentração micelar crítica dentro da dupla camada elétrica em concentração muito menor do que o valor previsto para o bulk.

\subsection{Comportamento da caulinita na flotação}

Pesquisas envolvendo a flotação de caulinita cresceram nos últimos anos. Por séculos, a caulinita tem sido utilizada na construção e na fabricação de cerâmicas, mosaico e porcelanas. Atualmente, grande parte dos estudos que envolvem flotação é do tipo reversa onde a caulinita é o mineral do rejeito (YUEHUA, 2004). Os chineses são os que mais publicam artigos sobre a flotação de caulinita, devido as suas grandes reservas de bauxita ricas em aluminossilicatos, onde o diásporo (óxido de alumínio hidratado) é o mineral de interesse (RODRIGUES,2009). 
A caulinita presente em minérios de bauxíticos aumenta o consumo de soda cáustica durante o processo Bayer (YUEHUA et al., 2004). Esse processo é aplicado para a purificação da bauxita, sua rota mais importante é utilizada para a manufatura de hidróxido e de óxido de alumínio (CONSTANTINO et al., 2002). De acordo com Fortuna et al (2012) nesse processo, sob pressão e temperatura controladas em um reator, a adição de $\mathrm{NaOH}$ dissolve o alumínio presente no mineral, formando o íon $\mathrm{Al}(\mathrm{OH}) 4^{-}$. O aluminato de sódio através de processos de espessamento e filtragem é separado da lama vermelha e precipitado na forma de hidróxido de alumínio $\mathrm{Al}(\mathrm{OH})_{3}$. Depois de seco o hidróxido de alumínio é calcinado a $1000^{\circ} \mathrm{C}$ e assim se obtém os cristais de alumina puros.

Para o processo Bayer a relação ideal entre $\mathrm{Al}_{2} \mathrm{O}_{3} / \mathrm{SiO}_{2}$ deve ser maior que 10 . Atualmente os minérios bauxíticos chineses apresentam uma relação de 5 a 8 , o que faz necessária uma pré-fase de concentração da caulinita (YUEHUA et al., 2004). A flotação é vista como uma solução para se alcançar produtos compatíveis com a necessidade da alimentação do processo de produção de alumina (RODRIGUES,2009).

Zhang et al. (2001) e Jiang et al. (2001) demonstraram que a caulinita tem baixa flotabilidade quando um coletor aniônico é usado. No entanto, a boa flotabilidade pode ser alcançada através de coletores catiônicos. Os coletores catiônicos (aminas e sais de quartanários de amônio) são os reagentes mais utilizados nos estudos que abordam flotação de caulinita (RODRIGUES et al., 2010). Embora a literatura descreva que a flotação com aminas apresenta seu melhor desempenho em pH >IEP onde a superfície do mineral está carregada negativamente o mecanismo de flotação catiônica não é adequadamente explicado, especialmente para caulinita de depósitos bauxiticos.

Jiang et al. (2014) estudaram o comportamento dos coletores Cloreto de dodeciltrimetil amônio (DTAC) e do Cloreto de cetiltrimetil amônio (CTAC) na flotação de caulinita. Os autores concluíram que a densidade de adsorção de ambos os coletores aumentam com o pH do meio, embora a recuperação da caulinita diminua com o aumento do $\mathrm{pH}$. Os autores também explicam que a recuperação com o coletor 
DTAC é mais significativa do que do CTAC, independentemente do $\mathrm{pH}$. Jiang et al. (2011) realizaram outro estudo com os mesmos reagentes, e para a caulinita, a medida que o comprimento da cadeia de carbonos dos coletores aumenta a recuperação na flotação também aumenta. Estudos de micro-polaridade mostraram que o CTAC é mais hidrofóbico do DTAC e que o comportamento anômalo da caulinita na flotação é atribuído à adsorção e agregação do coletor, assim como a estabilidade da espuma das moléculas de quartenário de amônio. Os resultados das recuperações na flotação para o mineral de caulinita são demonstrados nos itens 3.15.1 (DTAC) e 13.15.2 (CTAC) dessa dissertação.

Rodrigues et al. (2013) estudaram a seletividade do processo de flotação para os minerais de hematita e caulinita, tendo como objetivo reduzir os níveis de sílica e alumina do minério de ferro. Os coletores empregados nos ensaios de flotação foram o Flotigam EDA (Éter amina) e dois sais quartenários de amônio, o brometo de dodeciltrimetil amónio (DTAB) e Tomamine Q-14-2 PG (AQ142). Além disso, foi inserido no processo um depressor, o amido de milho. Utilizando o DTAB a melhor seletividade foi atingida entre o pH 4 e 10 .

Já com os coletores EDA e AQ142, a seletividade só foi atingida usando o amido de milho a um $\mathrm{pH}=10$. Os resultados de microflotação com um minério composto de ferro $(90 \%)$ e caulinita (10\%) a um pH 10 na presença de amido de milho são apresentados na figura 8 . A seletividade do processo de flotação foi de cerca de $65 \%$, e esse valor retrata as condições das usinas de flotação utilizando Flotigam EDA como coletor. As recuperações do mineral de caulinita com os coletores DTAB e AQ142 são apresentadas nos itens 3.15.3 e 3.15.4 dessa dissertação. 


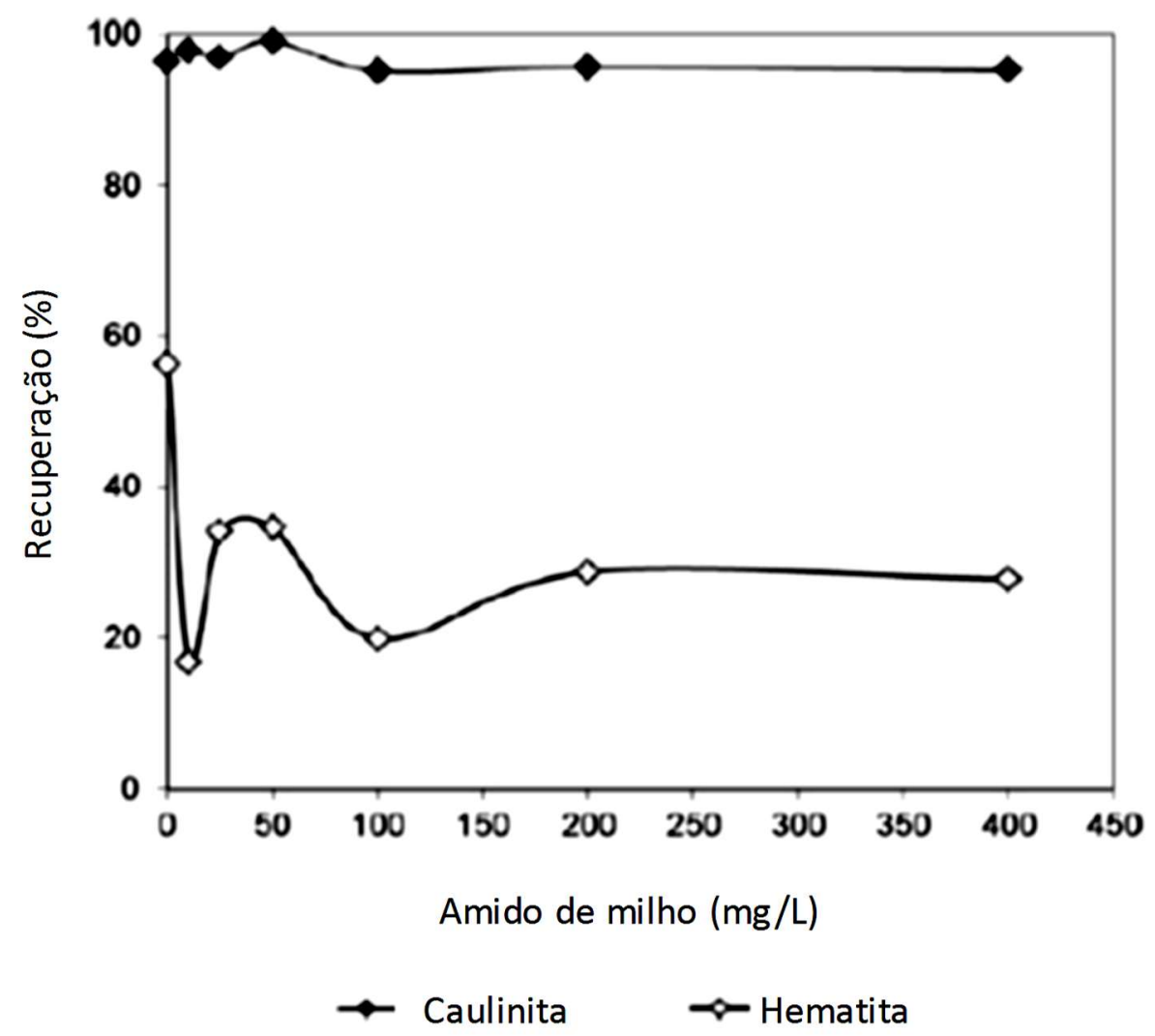

Figura 8 - Flotação de caulinita e hematita em função da concentração do amido de amido, utilizando Flotigam EDA (1x10-4 mol/L) a um pH =10

(RODRIGUES et al., 2012)

Ma, Bruckard e Holmes (2009) analisaram o efeito do coletor (aminas), do pH e da força iônica no comportamento da flotação da caulinita. Em ensaios de microflotação verificaram que a éter-diamina (Flotigam 2835-2L) é um ótimo coletor para sílica, embora, para caulinita não induza a flotação na faixa de $\mathrm{pH}$ de 3 até um pH de 10,5. Já a éter-monoamina (Flotigam EDA 3) é um bom coletor em altas dosagens para caulinita em $\mathrm{pH}$ ácidos. $\mathrm{Em} \mathrm{pH}$ mais básico a caulinita flota menos do que em $\mathrm{pH}$ mais ácidos. Os autores verificaram também que aumentando a força iônica do meio a flotação da caulinita será maior. Em ensaios utilizando a éter-diamina com uma força iônica de 0 para $0,5 \mathrm{M}$, a recuperação da flotação aumentou de $80 \%$ para $100 \%$ em uma ampla faixa de $\mathrm{pH}$. As respectivas recuperações dos testes de flotação para o mineral de caulinita estão retratados nos itens 3.15.14 (Flotigam EDA 3) e 3.15.15 (Flotigam 2835-2L). 
Zhao et al. (2003) estudaram o comportamento de aluminossilicatos na flotação com um reagente catiônico denominado $\mathrm{N}$ - (3-aminopropil)-dodecanamida (ADPA). Os minerais alvo foram a caulinita, ilita e pirofilita. Segundo os autores, as melhores recuperações na flotação foram respectivamente: $91,5 \%$ para caulinita $(\mathrm{pH} 3,8$ e concentração $\left.14 \times 10^{2} / \mathrm{g} . \mathrm{L}^{-1}\right), 90,6 \%$ para ilita $\left(\mathrm{pH} 2,7\right.$ e concentração $\left.14 \times 10^{2} / \mathrm{g} \cdot \mathrm{L}^{-1}\right)$

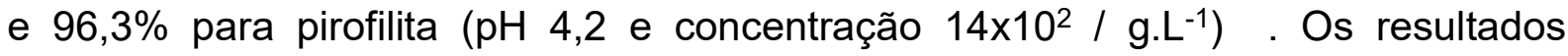
apresentados pelos autores mantendo a concentração do coletor $\mathrm{e}$ variado o $\mathrm{pH}$ estão no item de recuperações (3.15.21) dessa dissertação. O IEP da caulinita foi de 4,2 e sua recuperação diminui com o aumento do $\mathrm{pH}$. Os mecanismos de interação da superfície do mineral com o coletor dependem do $\mathrm{pH}$ da polpa. Em meio ácido o mecanismo de adsorção do coletor ocorre por atração eletrostático e em meio básico por ligação de hidrogênio.

Yuehua et al, (2004) estudaram a flotação de caulinita através de uma amina (grupo alquil de cadeia longa). A superfície da caulinita se torna mais negativa em $\mathrm{pH}$ mais básico, mas apresenta a melhor flotabilidade em pH ácido (Figura 9), situação que o modelo de atração eletrostática não explica, já que o coletor está carregado positivamente e a superfície da caulinita está carregada negativamente. Yoehua et al (2004), através de medidas de potencial zeta verificaram que o PZC da caulinita ocorre a um $\mathrm{pH}=4,2$. Esse comportamento anômalo da flotação de caulinita pode ser explicado através das diferenças nas interações entre DDA e as várias superfícies clivadas do mineral. Yuehua et al (2005) calculou a energia de adsorção, concluiu que o plano (001) é mais hidrofílico do que o plano (001), os planos são apresentados na Figura 10. A explicação de tal fenômeno é devido à adsorção de dodecilamina (DDA) ser preferencial octaedros de alumínio na face de tetraedros de silício (001), já que existe uma energia muito maior para adsorção de DDA no plano que contém os (001) do que no plano (001). 
(a) Solução ácida

Plano (001)

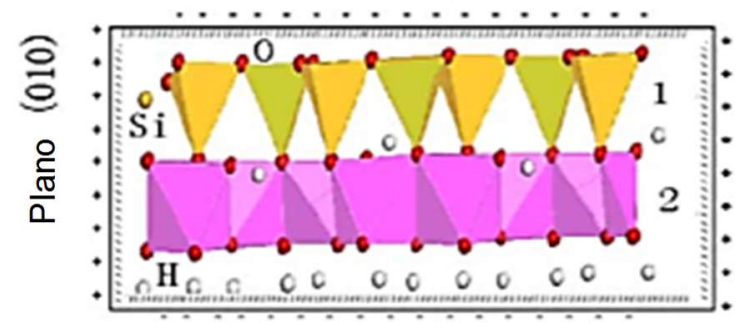

Plano $(00 \overline{1})$

1 - Tetraedros de silício

2- Octaedros de alumínio

(b) Solução alcalina

$$
\text { Plano (001) }
$$

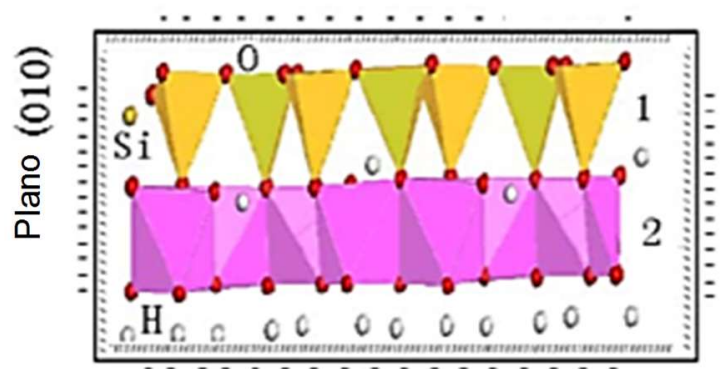

Plano $(00 \overline{1})$

Figura 9 - Superfície da caulinita em solução ácida (a) e solução alcalina (b). (YUEHUA ET AL., 2004)

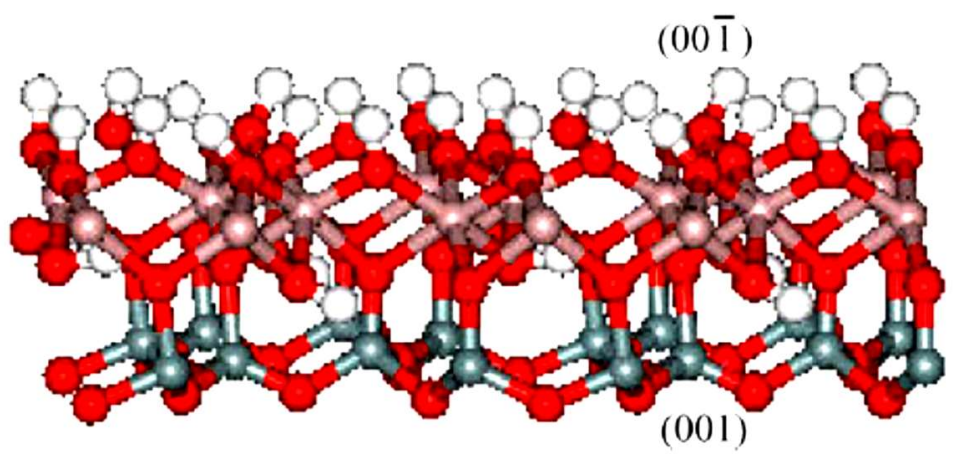

Figura 10 - Estrutura cristalográfica da caulinita, (001) $\mathrm{SiO}_{4}$ e (001) $\mathrm{AlO}_{2}(\mathrm{OH})_{4}$ (YUEHUA ET AL., 2004) 
Yuehua et al, (2004) trabalharam com macromoléculas-assistentes (polímeros) para minimizar a exposição da superfície mais hidrofílica das partículas da caulinita e aumentar a sua flotabilidade. Os polímeros, poliacrilamida modificada (APAM), agem como floculantes formando flóculos hidrofóbicos de caulinita. O APAM faz ligações de hidrogênio com os grupos $\mathrm{OH}$ ligados a átomos de alumínio. A adsorção do APAM (Figura 11) é preferível no plano (0 01 ) através de pontes de hidrogênio, condição de menor energia (maior presença de alumínio), o que diminuiu a exposição das superfícies hidrofílicas e aumenta a flotação da caulinita em uma ampla faixa de $\mathrm{pH}$. Os resultados completos de recuperação estão apresentados no item 3.15.17.

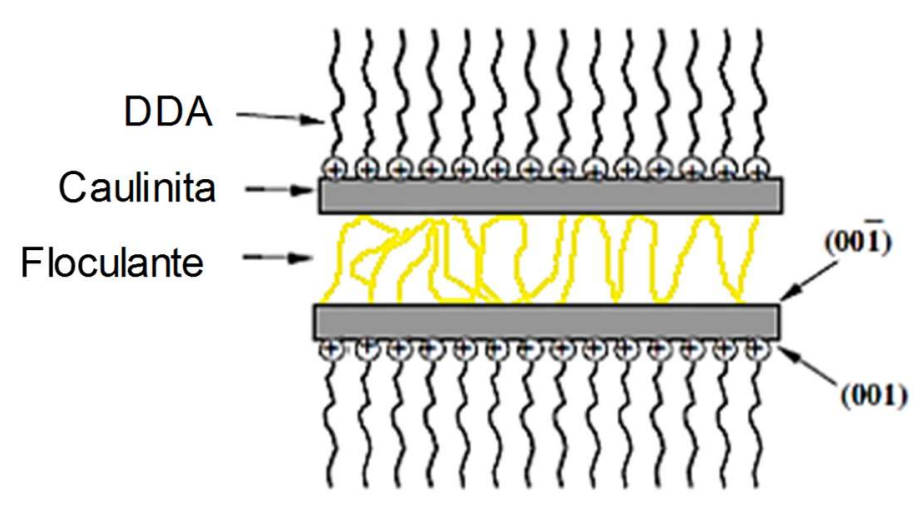

Figura 11 - Formação do floculo de caulinita na presença de DDA e floculante (PAAM). (YUEHUA ET AL., 2004)

Leal et al. (2008) estudaram a inflûencia do pH na cinética de adsorção de aminas em caulinita branca. Os testes foram utilizando soluções de $200 \mathrm{mgL}^{-1} \mathrm{de}$ acetato de eteramina (Flotigam EDA) em pH 4 e pH 10. Através dos experimentos de adsorção os autores verificaram que em 30 minutos a concentração de equilibrio já é atinjido. A adsorção de amina em caulinita branca é mais eficiente em meio básico; em $\mathrm{pH}=10$ obteve-se $75 \%$ de remoção da amina enquanto que para $\circ \mathrm{pH}=4$ foi somente $38 \%$ de remoção. Leal et al. (2009), com uma caulinita rosa, também verificaram a adsorção de eteramina nas concentrações iniciais 200 e $400 \mathrm{mgL}^{-1}$ no pH 4 e 10. A remoção máxima de amina ( $80 \%)$ foi obtida em pH 10 na concentração $200 \mathrm{mgL}^{-1}$. Segundo os autores, os dois estudos referidos, os resultados mostram que 
adsorção de amina em caulinita branca e rosa é mais eficiente em pH básico devido à maior carga negativa da caulinita neste faixa, que facilita a adsorção da amina na forma iônica na supefície das partículas, auxiliada pela amina na forma molecular.

$\mathrm{Hu}$, Jiang e Wang (2003) pesquisaram a eletrocinetica e o comportamento da caulinita em testes de flotação com soluções de brometo de cetiltrimetilamônio (CTAB). O PCZ da caulinita foi de 4,3. Sais de alquilamônio são amplamente utilizados como coletores para flotação de óxidos e sílicatos. Estudos de espectroscopia no infravermelho mostraram que em meio básico há uma maior adsorção, o que sugere o mecanismo de atração elestroestática. Já os testes de flotação do estudo mostraram que a caulinita apresentou melhor flotabilidade em $\mathrm{pH}$ ácidos (capítulo 5.2.5), embora o potencial zeta do mineral fique mais negativo no meio básico (Figura 12). Esse comportamento anômalo na flotação em vários intervalos de $\mathrm{pH}$ o autor atribui ao comportamento de agregação ou dispersão da caulinita e também a natureza das cargas dos planos basais e nas bordas. Segundo os autores, em soluções ácidas a borda da caulinita está positiva e o plano basal negativo e as parículas formam uma estrutura agregada denominada "card-house". Já no meio básico, ambos os planos estão negativos e não ocorre tal agregação.

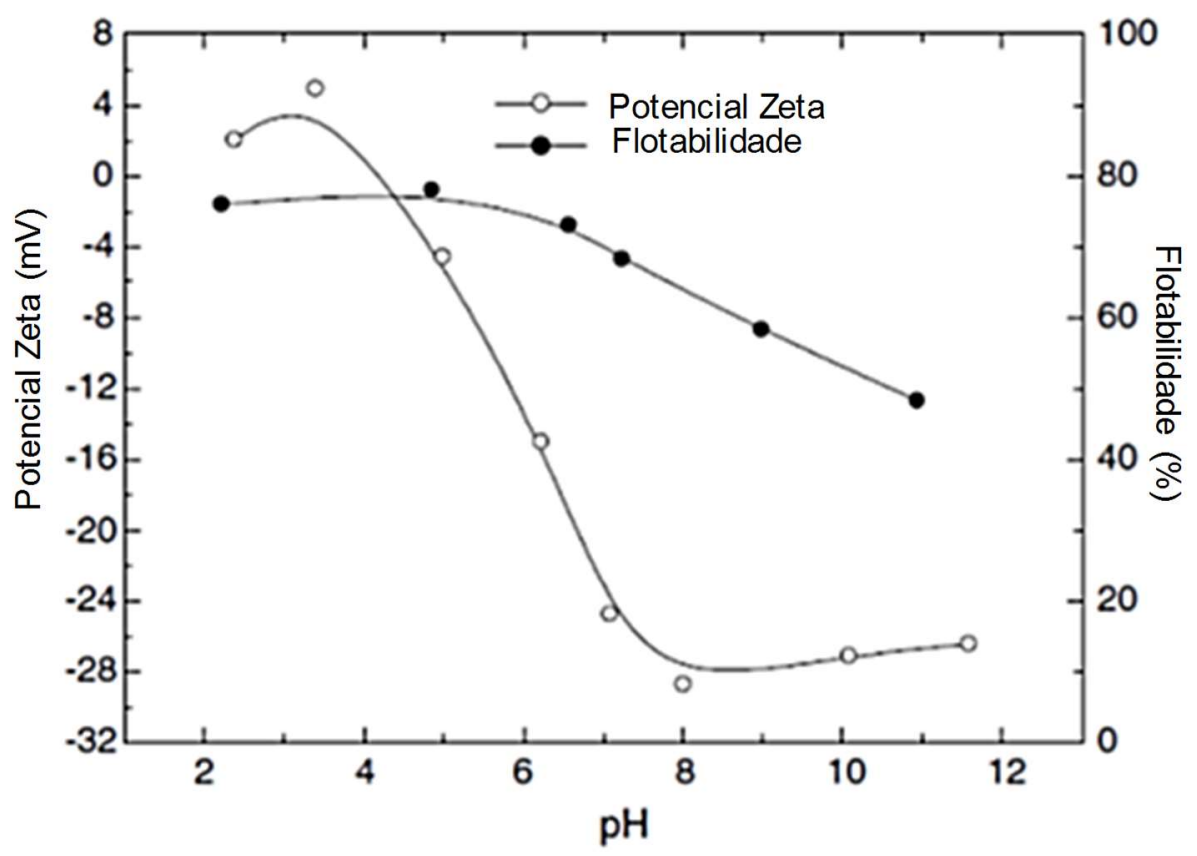


Figura 12 - Recuperação da flotação e potencial zeta da caulinita em função do pH usando CTAB (0,2Mm).(HU, JIANG E WANG, 2003)

Zhang et al. (2008) em testes de flotação a um pH = 6 com uma amina de cadeia longa ( $\mathrm{YC}$ ) usaram com êxito o depressor BK501 em um minério bauxítico com a finalidade de deprimir o diásporo (óxido de alumínio hidratado). Através de estudos de potencial zeta e estudos de espectroscopia no infravermelho os autores concluíram que a ótima flotabilidade da caulinita na presença do depressor, é devido a caulinita possuir superfície negativa, e desta forma o coletor catiônico adsorve mais fortemente no mineral.

Liu et al. (2011) através de ensaios de flotação utilizando como agente coletor, o N,N-dodecil dipropil amina (PN), estudaram a recuperação da caulinita e do diásporo. A máxima recuperação encontrada foi de $90 \%$ para caulinita, em um $\mathrm{pH}=$ 3 , e de $50 \%$ para o diásporo em um $\mathrm{pH}=9$ (item 3.15.16). Para ambos minerais, aumentado a dosagem do coletor as recuperações também aumentaram. De acordo com os atores a interação entre o coletor $\mathrm{PN}$ com a superfície carregada negativamente da caulinita e do diásporo é predominantemente eletrostática. Comparando o potencial zeta original dos dois minerais com o potencial zeta em contato com o PN, o potencial da caulinita aumentou muito mais do que o diásporo, fato que justifica a maior recuperação para caulinita do que para o diásporo.

Hu, Liu e Xu (2003) estudaram a molhabilidade e eletrocinética com minerais puros de caulinita, ilita e pirofilita. Os métodos utilizados nessa pesquisa foram: medidas de ângulo contato, ensaios de microflotação e medidas de potencial zeta. Como agentes coletores foram utilizados os reagentes: oeato de sódio, dodecilamina (DDA) e sal de alquilmônio quartenário (DDTA).

Os resultados das medidas de ângulo de contato mostram a molhabilidade de cada mineral; quanto maior o ângulo de contato maior será sua hidrofobicidade. Utilizando apenas água, o ângulo de contato foi $>40^{\circ}$ para pirofilita, mostrando uma moderada hidrofobicidade, $<10^{\circ}$ para caulinita e para ilita, o que sugere que esses 
últimos dois minerais não possuem hidrofobicidade natural (Figura 13). Já o diásporo mostrou-se completamente hidrofílico (HU; LIU; XU, 2003).

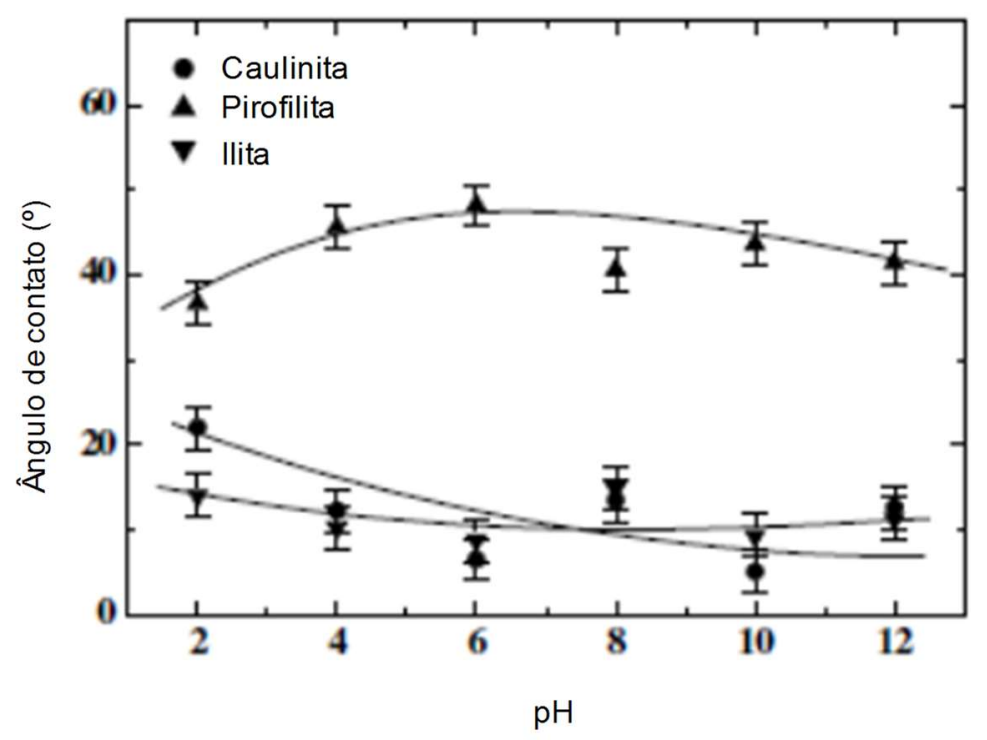

Figura 13 - Ângulo de contato da caulinita, pirofilita e ilita em função do pH (HU; LIU; XU, 2003)

A molhabilidade de cada mineral foi alterada adicionando no sistema $0,2 \mathrm{mM}$ de uma amina (DDA). A pirofilita mostrou-se mais hidrofóbica, atingindo valores superiores a $65^{\circ}$. Já a caulinita atingiu valores próximos a $50^{\circ}$, e a ilita $40^{\circ}$ (Figura 14). O ângulo de contato do diásporo teve um pequeno aumento, passou de $0^{\circ}$ para $20^{\circ}$. Tais resultados indicam uma possibilidade de flotação reversa de minerais aluminossilicatos do diásporo utilizando a DDA como agente coletor (HU; LIU; XU, 2003). 


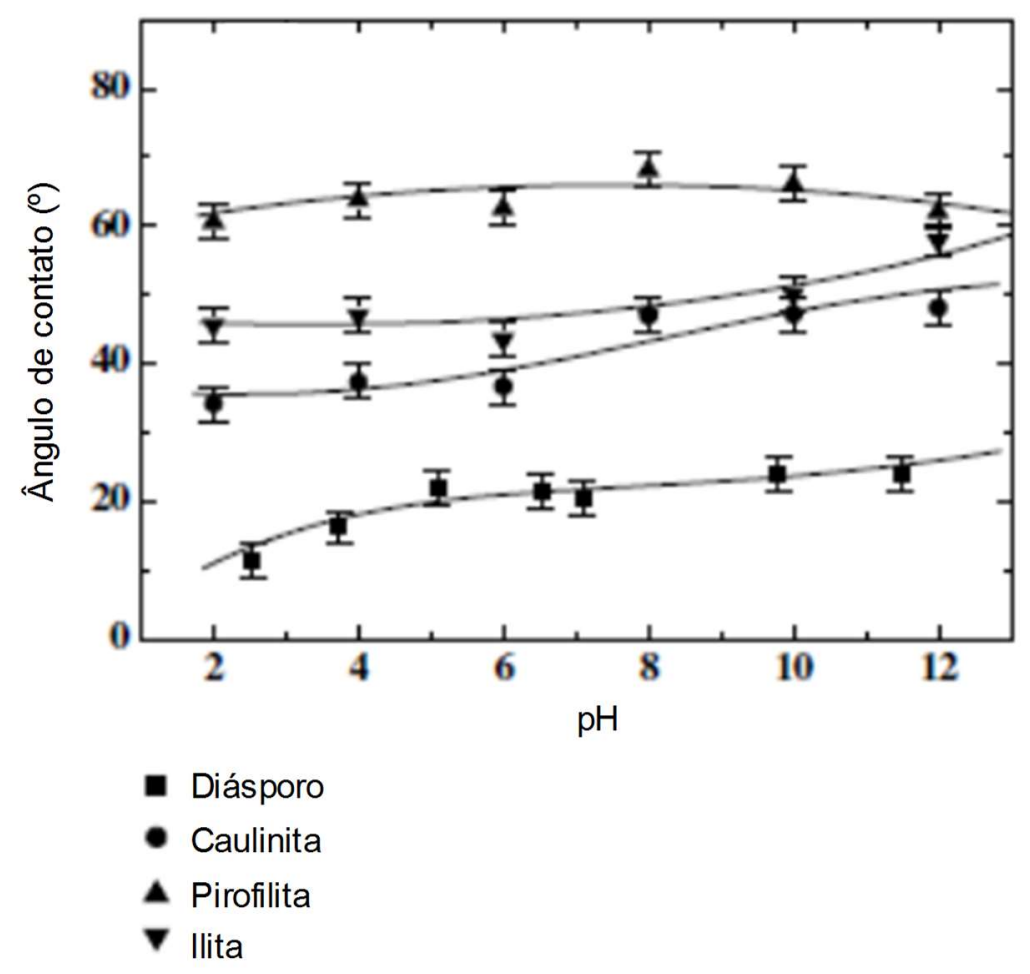

Figura 14 - Ângulo de contato do diásporo, caulinita, pirofilita eilita com uma solução de 0,2 mM DDA em função do pH (HU; LIU; XU, 2003)

Os resultados obtidos com o diásporo nos testes de ângulo de contato com 0.2 $\mathrm{mM}$ de oleato mostraram que as moléculas de oleato claramente se adsorvem na superfície do óxido de alumínio. As interações entre as moléculas do oleato com a pirofilita e com ilita foram extremamente fracas. Já a caulinita apresentou uma boa hidrofobicidade em um pH próximo de 4 (Figura 15). 


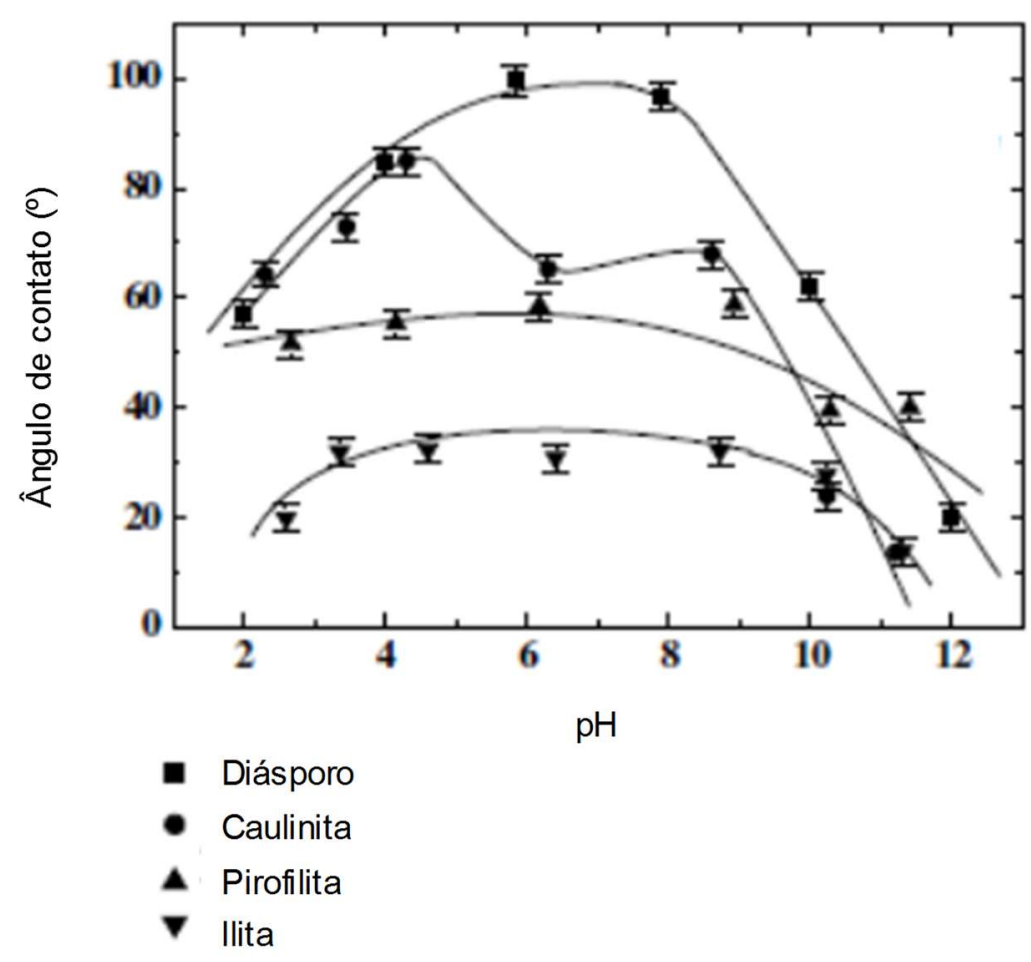

Figura 15 - Ângulo de contato do disporo, caulinita, pirofilita e ilita com uma solução de 0,2 mM de oleato em função do pH (HU; LIU; XU, 2003)

Os IEP do diásporo, caulinita, ilita e da pirofilita foram respectivamente: 6,4, 3,6, 2,8 e 2,4 (Figura 16). Através da curva os autores Hu, Liu e Xu (2003) supuseram que o mecanismo de adsorção do coletor na superfície do mineral é eletrostática e seguem duas ideias. A primeira ideia é da flotação direta entre o pH 4 e 6 com coletores aniônicos. Todos os aluminossilicatos nessa faixa de $\mathrm{pH}$ possuem carga negativa e, o diásporo, positiva. Já a segunda ideia é a flotação reversa do diásporo com coletores catiônicos, onde a caulinita é flotada. 


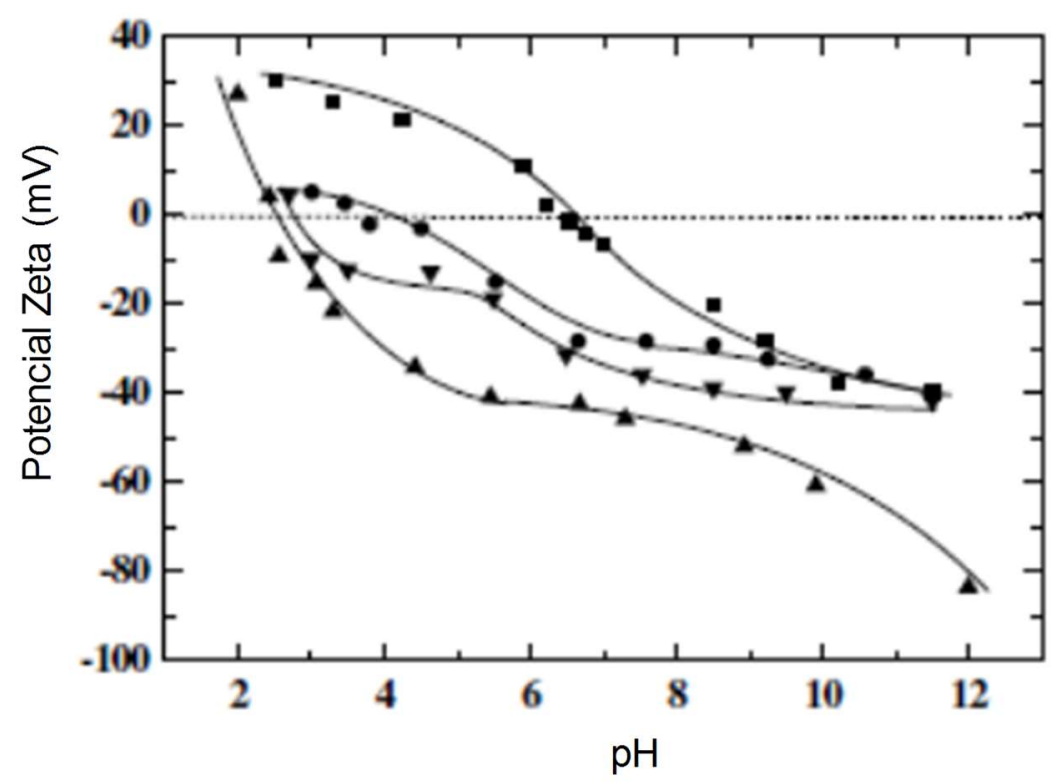

- Diásporo
- Caulinita
- Pirofilita
v llita

Figura 16 - Potencial zeta do diásporo, caulinita, pirofilita e ilita medida em soluções de 1 mM de KCL em função do pH (HU; LIU; XU, 2003)

Hu, Liu e Xu (2003) empregando dois coletores, DDA e DDTA, realizaram testes de flotação com as amostras puras de caulinita, ilita e pirofilita. Os dois reagentes se mostraram bons coletores para aluminossilicatos. A flotabilidade dos minerais seguiu a mesma ordem de molhabilidade, ou seja, pirofilita> caulinita> ilita e os aluminossilicatos apresentaram melhor flotabilidade em meio ácido (resultados das recuperações da caulinita na flotação no item 13.15.7 para DDTA e 3.15.17 para DDA), e o diásporo, em meio alcalino.

No mesmo artigo os autores apresentam o cálculo da razão de ligações rompidas (na fragmentação) entre $\mathrm{Al}-\mathrm{O}$ e $\mathrm{Si}-\mathrm{O}$. O resultado do cálculo ajuda a explicar as propriedades superficiais do mineral e a sua resposta à flotação. Observaram que a ordem de rompimento é inversa à da hidrofobicidade com um 
coletor catiônico. Quanto menor a razão de ligações rompidas para pirofilita e ilita, menor é adsorção do coletor catiônico na superfície desses minerais. As propriedades superficiais da caulinita são bastante semelhantes a do diásporo, e este é um dos fatores que dificulta a seletividade na flotação.

Considerando a grande semelhança química entre feldspato e a caulinita, Köster et al. (1992) elaboraram um trabalho de caráter fundamental para a flotação. $\mathrm{Na}$ presença de partículas extremamente finas $(<5 \mu \mathrm{m})$, utilizando três coletores diferentes: dois coletores catiônicos (Cloreto de cetilpiridina - CCPI e hidroxiamina AMD): e um coletor aniônico (Dodecil benzeno sulfonato de sódio - SDBS ou A55). $\mathrm{O}$ pH dos ensaios de flotação foi de 3 até 7,5. Nesse estudo, os autores trabalharam com amostras com três diferentes distribuições de tamanho de partícula (Figura 17).

\begin{tabular}{lccr}
\hline & \multicolumn{3}{c}{ Amostra de caulinita } \\
\hline $\begin{array}{c}\text { Tamanho de partícula } \\
(\mu \mathrm{m})\end{array}$ & K I & K II & K III \\
& & & \\
\hline$>45$ & 4.3 & 3.5 & - \\
10.45 & 82.0 & 69.0 & 69.5 \\
2.10 & 13.7 & 27.5 & 24.4 \\
$<2$ & - & - & 6.1 \\
\hline
\end{tabular}

Figura 17- Distribuição de tamanho de três amostras de caulinita (KÖSTER et al.1992

Nos ensaios de flotação, a maior seletividade encontrada entre a caulinita e o feldspato foi com o coletor CCPI (Figura 18). Esse resultado é devido à presença de íons de alumínio no sistema de flotação. Os íons de alumínio junto com o coletor competem pela superfície do feldspato tornando sua superfície menos hidrofóbica, em nada influenciando a ação do coletor na superfície da caulinita (KÖSTER et at.1992). 


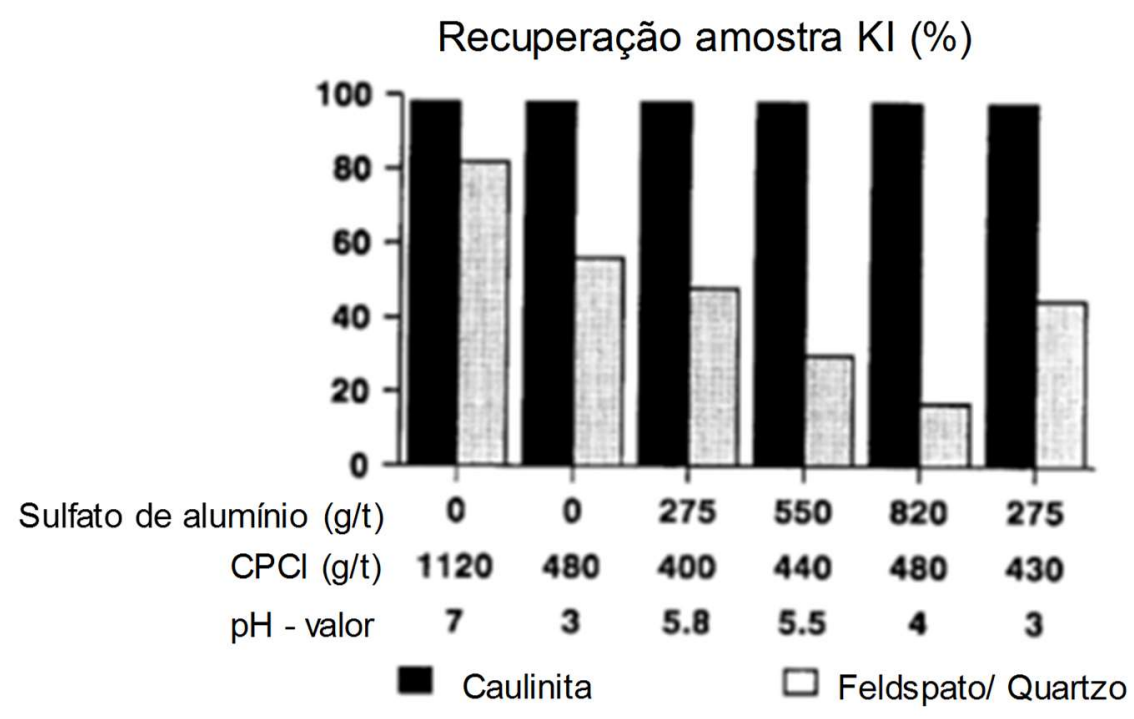

Figura 18 - Recuperação de caulinita e feldspato em ensaios de flotação de bancada com KI (amostra com maior quantidade de finos) usando como coletor $\mathrm{CPCl}$

(KÖSTER et at.1992)

Para o coletor AMD, os resultados obtidos pelos autores são apresentados na figura 19. O AMD mostrou-se mais eficiente em $\mathrm{pH}$ neutro. Nessa faixa de $\mathrm{pH}, \mathrm{a}$ necessidade de coletor no sistema de flotação foi menor do que para o CPLI. Além disso, o AMD foi mais eficiente na flotação de amostras mais difíceis como: KII e KIII (figura 17). A adição de íons de alumínio foi satisfatória para os dois coletores catiônicos. Os autores ainda concluem que tanto para o AMD como para o CPLI o aumento da seletividade não é simplesmente atribuído à mudança de pH (KÖSTER et at.1992). 

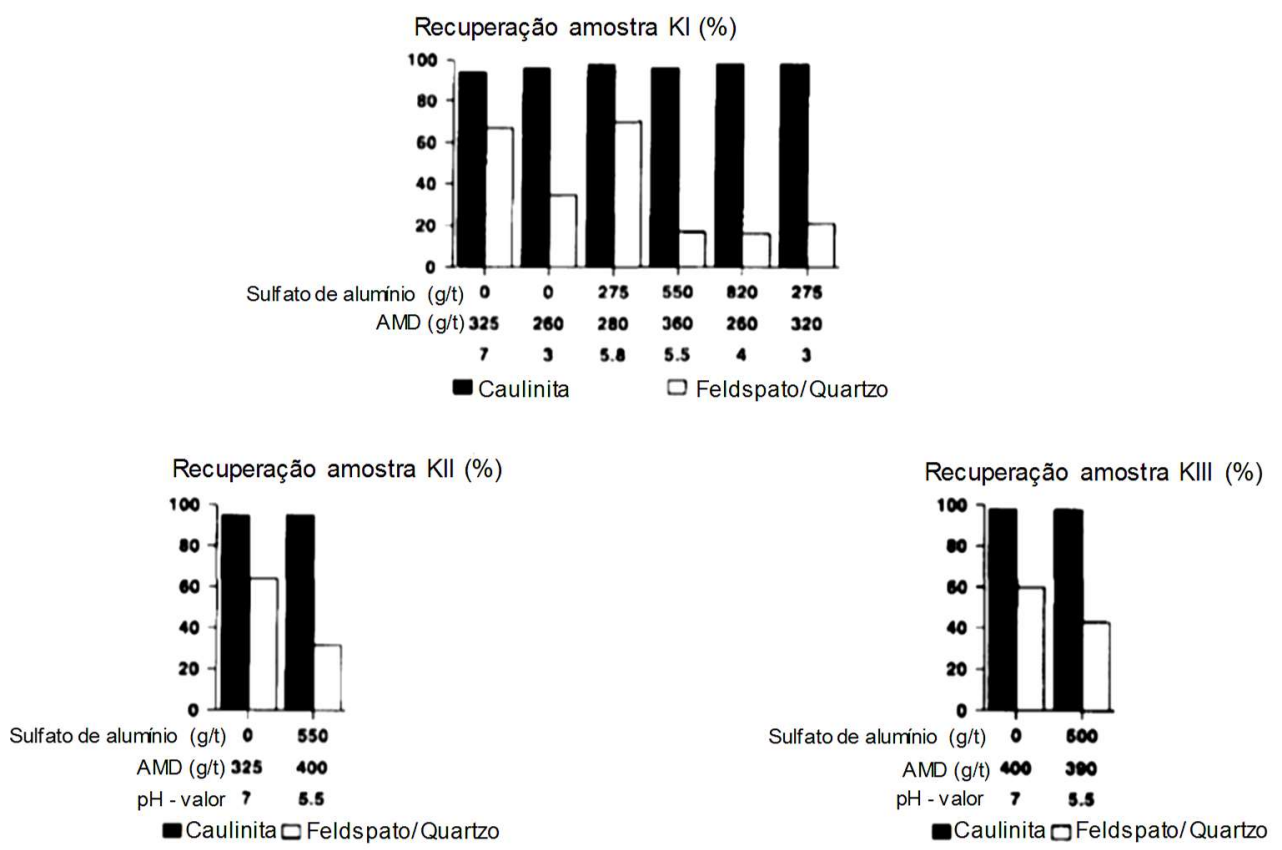

Figura 19 - Recuperação da caulinita e feldspato em ensaios de flotação com o coletor AMD para as três granulometrias da tabela 1 (KÖSTER et at.1992)

Como a superfície da caulinita possui planos positivos e negativos, um coletor aniônico também pode ser adsorvido na superfície do mineral. O coletor aniônico, dodecilbenzenosulfonato de sódio (SDBS), apesar de apresentar uma seletividade entre os minerais de caulinita e feldspato, não foi igualmente eficiente como os coletores catiônicos (KÖSTER et at.1992).

O coletor aniônico adsorve na superfície da caulinita em pH ácido. Esse fenômeno é atribuído aos sítios da caulinita que estão positivos devido ao recobrimento da sua superfície por íons $\mathrm{H}^{+}$, que nesse caso desempenham o papel de ativadores. Para a amostra KI ( figura 17) a adição dos íons de alumínio favorece a seletividade do processo. Já para a amostra KII a adição dos íons de alumínio favorece a flotabilidade, mas não é seletivo (Figura 20). O coletor aniônico não foi seletivo para partículas finas (KÖSTER et at.1992). 

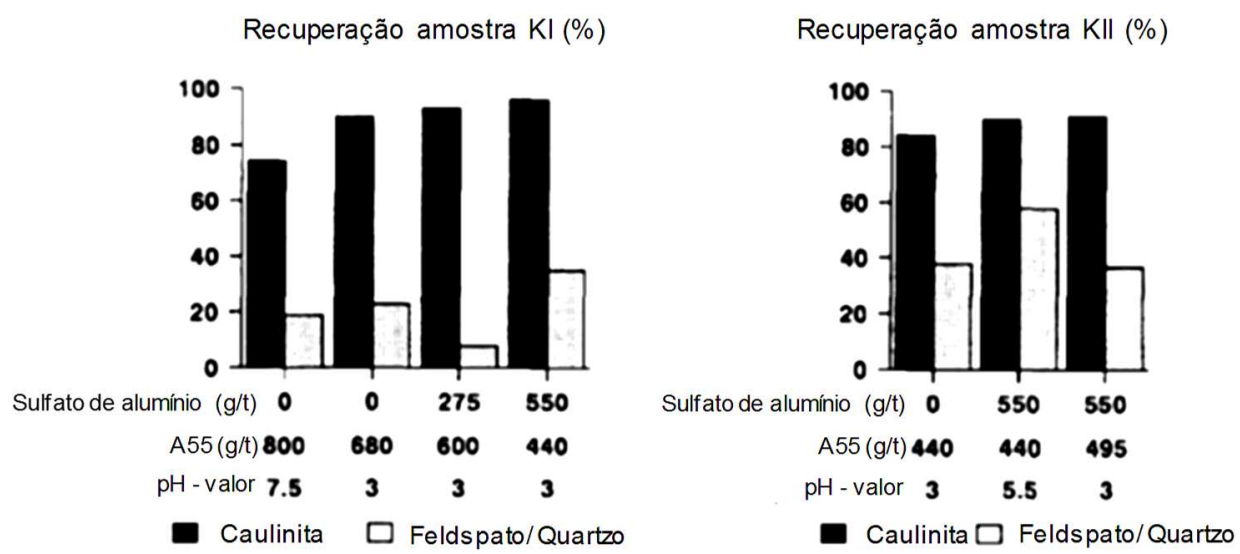

Figura 20 - Recuperações de caulinita e feldspato em ensaios de flotação de bancada com o coletor dodecilbenzenosulfonato de sódio (Amostras KI e KII) (KÖSTER et at.1992)

XIA et al (2009) realizou um estudo utilizando dois coletores da classe dos sais quartanários de amônio: Brometo de dimetil dodecil amônio dissubstituído (12-4-12) e Brometo de dodeciltrimetil amônio (DTAB). Conforme os resultados dos ensaios de flotação, a máxima recuperação de caulinita, pirofilita e ilita para ambos os coletores ocorreram em um pH próximo de 6, o coletor 12-4-12 é mais eficiente que o DTAB. Os resultados de recuperação na flotação para caulinita são apresentados nos itens 3.15.3 (DTAB) e 3.15.16 (12-4-12).

A figura 21 mostra os resultados para o mineral de caulinita para os testes de potencial zeta. O IEP da caulinita ocorreu em um pH igual de 3,4. Com os coletores 12-4-12 e DTAB os resultados mostram uma mudança acentuada na direção positiva, e os autores concluem que as moléculas dos coletores carregadas positivamente foram adsorvidas sobre o mineral pela força eletrostática resultando em uma superfície mais positiva. Os autores retratam que os dois coletores estudados têm uma atração eletrostática semelhante um com a do outro. 


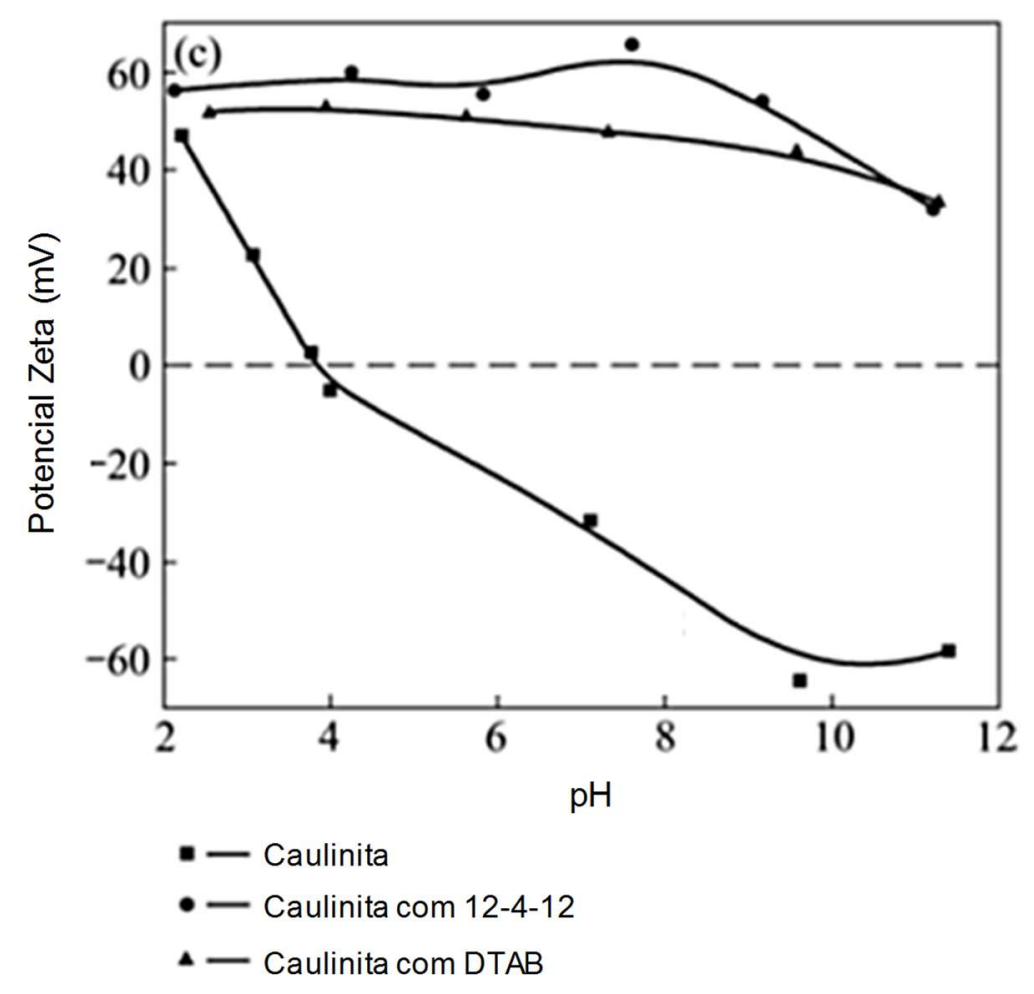

Figura 21 - Potencial zeta da caulinita em função do pH com coletores 12-4-12 e DTAB. (XIA et al. 2009)

HUANG et al (2013) elaboram um artigo com coletores de sal quartanário de amônio semelhantes a do XIA et al (2009). Foram utilizados coletores denominados "gêmeos", são eles: brometo de dimetildodecil amônio dissubstituído (BDDA) e Brometo dodecildimetil amônio (EDDA). Os autores observaram que a máxima recuperação nos ensaios de flotação para o mineral de caulinita ocorre em pH inferiores a 8 (tais valores encontram-se no item 3.15.9 dessa dissertação para o coletor EDDA). Os autores concluem que as atrações eletrostáticas e as ligações de hidrogênio são os mecanismos de adsorção dos cátions dos coletores na superfície do mineral. As ligações de hidrogênio ocorrem abaixo do pH de IEP, para caulinita próximo do pH 4 (Figura 22). Os cálculos por DFT (Teoria do Funcional Densidade) apresentados no artigo demonstram que BDDA é mais eficiente que o EDDA. 


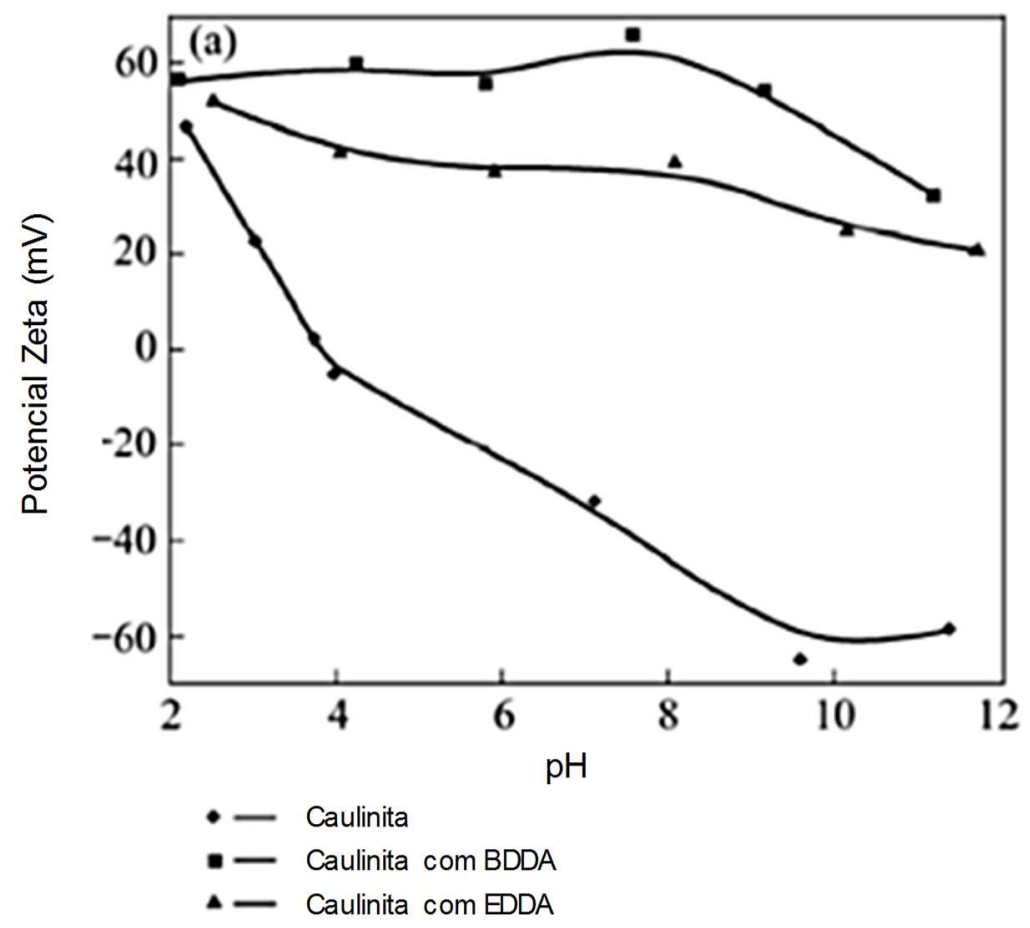

Figura 22 - Potencial zeta da caulinita em função do pH com coletores BDDA e EDDA. (HUANG et al. 2013)

Guan et al (2009) estudaram o comportamento da flotação do mineral de caulinita utilizando uma série de coletores da família da alquilguanidina: sulfato de hexil guanidina (SAG6), sulfato de octilguanidina (SAG8), sulfato de decilguanidina (SAG10) e sulfato dodecilguanidina (SAG12). Os resultados encontrados pelos autores nos testes de flotação mostram uma alta recuperação do mineral de caulinita para os coletores SAG8, SAG10 e SAG12, e quanto maior a cadeia carbônica do coletor maior a recuperação do mineral nos ensaios de flotação. Os resultados de recuperações dos coletores podem ser visualizados no item 3.15.35. Os autores utilizaram espectroscopia para analisar a adsorção dos reagentes na superfície dos aluminossilicatos, e concluíram que o coletor é adsorvido principalmente pela atração eletroestática e por ligações de hidrogênio, e que nenhuma reação química foi observada durante o estudo. A forte atração dos coletores na superfície da caulinita 
em pH inferior do seu IEP $(3,5)$ é explicada através da estrutura de guanidina que tem grupos $-\mathrm{NH}_{2}$. Conforme os autores, talvez um deles interaja com os minerais por forças eletrostáticas e o outro grupo forme ligações de hidrogênio com íos de $\mathrm{OH}$ sobre a superfície do aluminossilicato, acarretando um aumento de carga negativa na superfície do mineral.

\section{Avaliação Bibliométrica}

Bibliometria pode ser definida como um conjunto de leis e princípios empíricos que contribuem para estabelecer os fundamentos teóricos da Ciência da Informação. Conforme Guedes e Borschiver (sem data) a bibliografia Estatística surgiu no ano de 1922 por Wyndham Hulme por meio de uma contagem de documentos. Conforme Araujo (2006) o termo bibliometria foi citado pela primeira vez no ano de 1934 por Otlet em seu "Traité de Documentation". Em 1944, Gosnell com um artigo sobre obsolescência da literatura, citou o termo statistical bibliography pela segunda vez em seus trabalhos. A terceira vez que o termo apareceu no meio científico foi através de um artigo sobre análise de citações, Statistical bibliograpHy in health sciences, Raisig. O pesquisador reportou que existia um consenso entre autores dedicados ao assunto, e que o termo statistical bibliography não era de todo satisfatório devido a seu escasso emprego na literatura (GUEDES E BORSCHIVER, sem data). No ano de 1969 Pritchard popularizou o termo na sua discussão polêmica "bibliografia estatística ou bibliometria?". Conforme a tradução de Araujo (2006) dos trabalhos de Nicholas e Ritchie (1978) a diferença essencial entre a tradicional bibliografia e a bibliometria é que a última utiliza mais métodos quantitativos do que discursivos, ou seja, busca por uma avaliação objetiva da produção científica. Price (1976. Apud Araújo, 2006) faz referência da bibliometria da seguinte forma:

Deixando de lado os julgamentos de valor, parece clara a importância de se dispor de uma distribuição que nos informe sobre o número de autores, trabalhos, países ou revistas que existem em cada categoria de produtividade, utilidade ou o que mais desejarmos saber (PRICE, 1976. Apud Araújo, 2006). 
Conforme Figueiredo (1997) a bibliometria é definida por sua dupla preocupação: a análise da produção científica e a busca de benefícios práticos imediatos para bibliotecas e a promoção do controle bibliográfico (Figueiredo, 1977. Apud Araújo, 2006).

A bibliometria estática é um estudo dos aspectos quantitativos da produção, pois desenvolve medidas matemáticas e estáticas sobre as informações publicas. $O$ objetivo é elaborar previsões e apoiar tomadas de decisão (TAGUE-SUTCLIFFE, 1992. Apud Vianna, 2012). Guedes e Borschiver (sem data) realizaram um estudo fundamental definindo a bibliometria como:

A Bibliometria é uma ferramenta estatística que permite mapear e gerar diferentes indicadores de tratamento e gestão da informação e do conhecimento, especialmente em sistemas de informação e de comunicação científicos e tecnológicos, e de produtividade, necessários ao planejamento, avaliação e gestão da ciência e da tecnologia, de uma determinada comunidade científica ou país (GUEDES e BORSCHIVER, sem data).

Guedes e Borschiver (sem data) ainda mencionam a bibliometria como um instrumento quantitativo, que permite minimizar a subjetividade inerente à indexação e recuperação das informações, produzindo conhecimento, em determinada área de assunto. De acordo com as autoras a bibliometria contribui para tomadas de decisão na gestão da informação e do conhecimento, uma vez que auxilia na organização e sistematização de informações científicas e tecnológicas.

As principais leis que regem a bibliometria são enunciadas por três pesquisadores: Lotka, Zipf e Brandfors (Figura 23). Vanti (2002) define as três leis da seguinte maneira:

A lei de Lotka, ou Lei do Quadrado Inverso, aponta para a medição da produtividade dos autores, mediante um modelo de distribuição tamanhofrequência dos diversos autores em um conjunto de documentos. A Lei de Zipf, também conhecida como Lei do Mínimo Esforço, consiste bem medir a frequência do aparecimento das palavras em vários textos, gerando uma lista ordenada de termos de uma determinada disciplina ou assunto. Já a Lei de Bradford, ou Lei de Dispersão, permite, mediante a medição da produtividade das revistas, estabelecer o núcleo e as áreas de dispersão sobre um determinado assunto em um mesmo conjunto de revistas (VANTI, 2002. Apud VIANNA, 2012). 


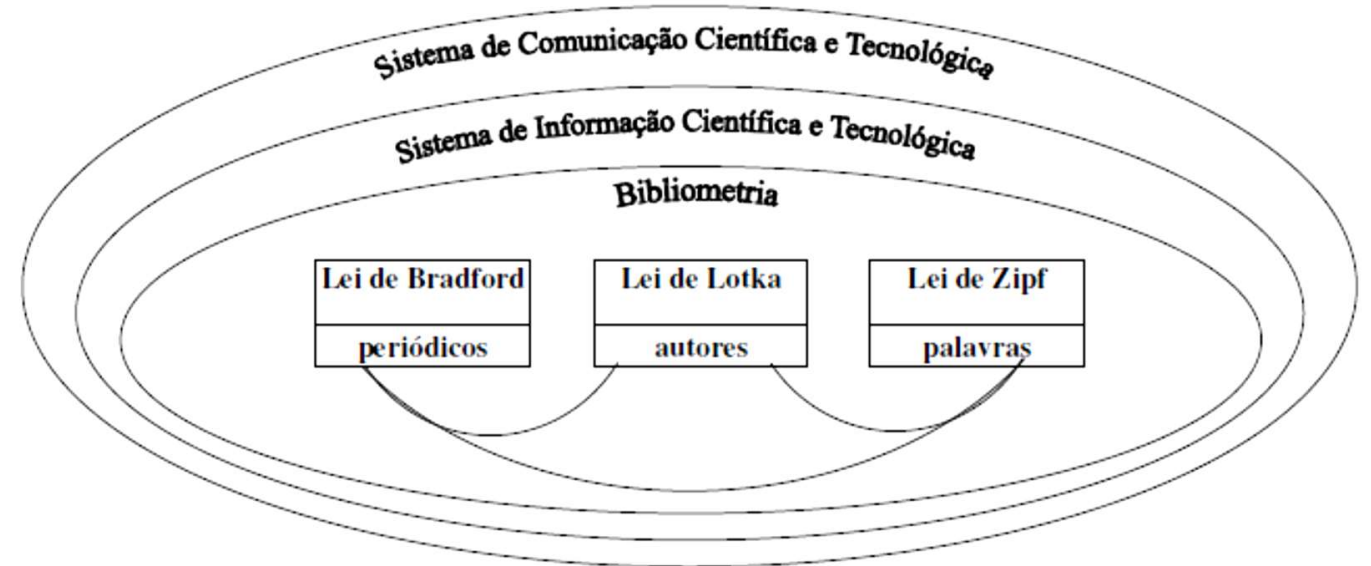

Figura 23 - Principais leis da Bibliometria e seus focos de estudo (GUEDES E BORSCHIVER, sem data)

Conforme Araujo (2006), a lei do Quadrado Inverso formulada em 1926 reporta que: uma larga proporção da literatura científica é produzida por um pequeno número de autores, um grande número de pequenos produtores se iguala, em produção, ao reduzido número de grandes produtores.

A segunda lei bibliométrica, lei do Mínimo esforço, faz referência ao uso das mesmas palavras em um mesmo documento, ou seja, dependendo da quantidade de vezes que uma ou mais palavras são citadas em um mesmo trabalho, essas palavras indicam o assunto do trabalho.

A última lei, Lei de Dispersão, incide sobre o conjunto de períodos com o objetivo de descobrir a extensão na qual artigos de um assunto científico específico aparecem em periódicos destinados a outros assuntos. Dessa forma o Bradford, estuda a distribuição dos artigos em termos de variáveis de aproximidade ou de afastamento. Araujo (2006) concluiu através da Lei de Bradford que:

Ordenando uma grande coleção de periódicos em ordem de produtividade decrescente relevante a um dado assunto, três zonas aparecem, cada uma contento $1 / 3$ do total de artigos relevantes (a primeira zona contém um pequeno número de periódicos altamnte produtivos, a segunda contém um número maior de periódicos menos produtivos, e a terceira inclui mais periódicos ainda, mas cada um com menos produtividade). 


\section{METODOLOGIA}

Este trabalho teve uma abordagem empírica. Vianna (2012) descreve que esse tipo de estudo com abordagem empírica se caracteriza através de uma pesquisa descritiva que estabelece relações entre os fatos, descrevendo e explicando os fenômenos através de análises estatísticas.

O corpo desse trabalho é composto por uma revisão bibliográfica e levantamento que: caracteriza o mineral de caulinita, descreve os estudos já realizados utilizando tensoativos na flotação como método de separação de partículas, e faz uma análise bibliométrica dos artigos publicados sobre a flotação de caulinita selecionados no ScienceDirect.

\subsection{Revisão Bibliográfica}

Inicialmente foi realizada uma revisão bibliográfica sobre as argilas, suas características mineralógicas e o porquê o mineral de caulinita pertence ao grupo dos filossilicatos. A história da caulinita também foi abordada; procurou-se descrever a utilização da caulinita desde a descoberta do mineral como matéria-prima até a sua importância na indústria nos dias atuais. Em seguida, buscou-se apresentar as diversas formas de gênese dos minerais argilosos, evidenciado a formação do mineral de caulinita. Compreender cada modelo de formação de caulinita é fundamental, pois cada depósito possui características únicas que interferem nos aspectos fundamentais de flotação.

Como a flotação explora as diferenças nas características de superfície entre várias espécies de minerais, a estrutura e a carga superficial da caulinita também foram discutidas. Uma revisão de literatura explicando o processo de flotação como operação unitária de separação também foi elaborado. Esse último capítulo foi escrito com intuitivo de contextualizar os aspectos fundamentais da flotação para posteriormente descrever os aspectos únicos na flotação de caulinita. 
Utilizando como referência a dissertação de mestrado de Neder (2005), dois capítulos foram elaborados: tensoativos e aminas. Esses dois tópicos foram produzidos a fim de explicar as características principais das aminas já que essas são os agentes coletores principais na flotação de caulinita. O item Flotação de silicatos com aminas foi elaborado para explicar as interações entre aminas graxas e os silicatos, já que existe um consenso geral que o mecanismo de adsorção de aminas graxas em silicatos depende do $\mathrm{pH}$ do meio. $\mathrm{O}$ item Comportamento da caulinita na flotação é mais especifico, descreve a divergência entre o pH de flotação de caulinita de autores brasileiros contraposto com os artigos encontrados a grande maioria de autoria chinesa. Além disso, relata a quantidade numerosa de tensoativos estudados na flotação de caulinita. Por fim, para o cumprimento do objetivo desse trabalho, foi realizado uma busca para descrever as características de uma análise bibliométrica.

\subsection{Coleta de Dados}

A base de dados SciVerse ScienceDirect, disponível no endereço eletrônico http://www.sciencedirect.com/ foi utilizada como o sistema de busca de artigos. Este site, pertencente à editora Elsivier, e foi criado no ano de 1999 e é o líder atual no ramo de bibliotecas digitais e possui uma coleção eletrônica de textos completos originários de mais de 2.500 revistas científicas totalizando ao todo mais de 13 milhões de artigos nas áreas cientificas, tecnológicas e médica. $O$ banco de dados possui cerca de 30 mil livros e $25 \%$ dos documentos científicos do mundo estão no ScienceDirect (ELSEVIER,2015).

A busca por artigos foi realizada através das palavras: Flotation of Kaolinite, Flotation of Aluminosilicate e Flotation of Diaspore. "Flotation of Aluminosilicate", pois em muitos casos - principalmente na China - caulinita é um mineral presente nos processos físico-químicos de interfaces dos aluminossilicatos; Flotation of Diaspore, dado que a caulinita na China é separada do mineral diásporo através de uma flotação reversa do óxido de alumínio. Essas palavras foram inseridas nos campos do site: título, resumo e palavras-chave. Definiu-se como fronteira temporal o período de 1992 até 2015. 
Foram encontrados ao todo 67 artigos em inglês para a busca de "Flotation of Kaolinite". Para "Flotation of Aluminosilicate" foram encontrados 22 artigos em inglês onde a palavra "kaolinite" está presente. E por fim, para "Flotation Diaspore" 23 artigos em inglês que citam a palavra "kaolinite". No banco de dados do ScienceDirect as palavras-chave não estão obrigatoriamente todas em um único artigo, desta forma, os 112 artigos foram analisados inicialmente.

Para facilitar a análise dos 112 artigos, os dados foram exportados em formato BibTex para uma planilha eletrônica do Software Exel. Cada artigo exportado contém os itens (Figura 24): palavras-chave, autoria, nome do periódico, volume, número, página inicial, página final, o mês e o ano de publicação e o resumo.

Todos os dados exportados, title - journal - volume - number - e outros, foram classificados de acordo com o conjunto de informações de cada artigo (Coluna A da Figura 24) e numerados conforme a sua sequência na planilha (Coluna B da Figura 24). Depois de uma análise individual nos 112 artigos com intuito de verificar se o artigo atendia ou não o objetivo dessa dissertação, o artigo foi definido como sim, atende os objetivos (os artigos dispõem de testes ou resultados de flotação com o mineral de caulinita) ou como não, não atende os objetivos dessa dissertação (Coluna C da Figura 24). Na coluna "D" o artigo classificado como "sim" na coluna C, foi numerado novamente em relação à nova planilha Excel (Figura 24), planilha só com os artigos que atendem o objetivo desse estudo, ao todo, 39 artigos. 


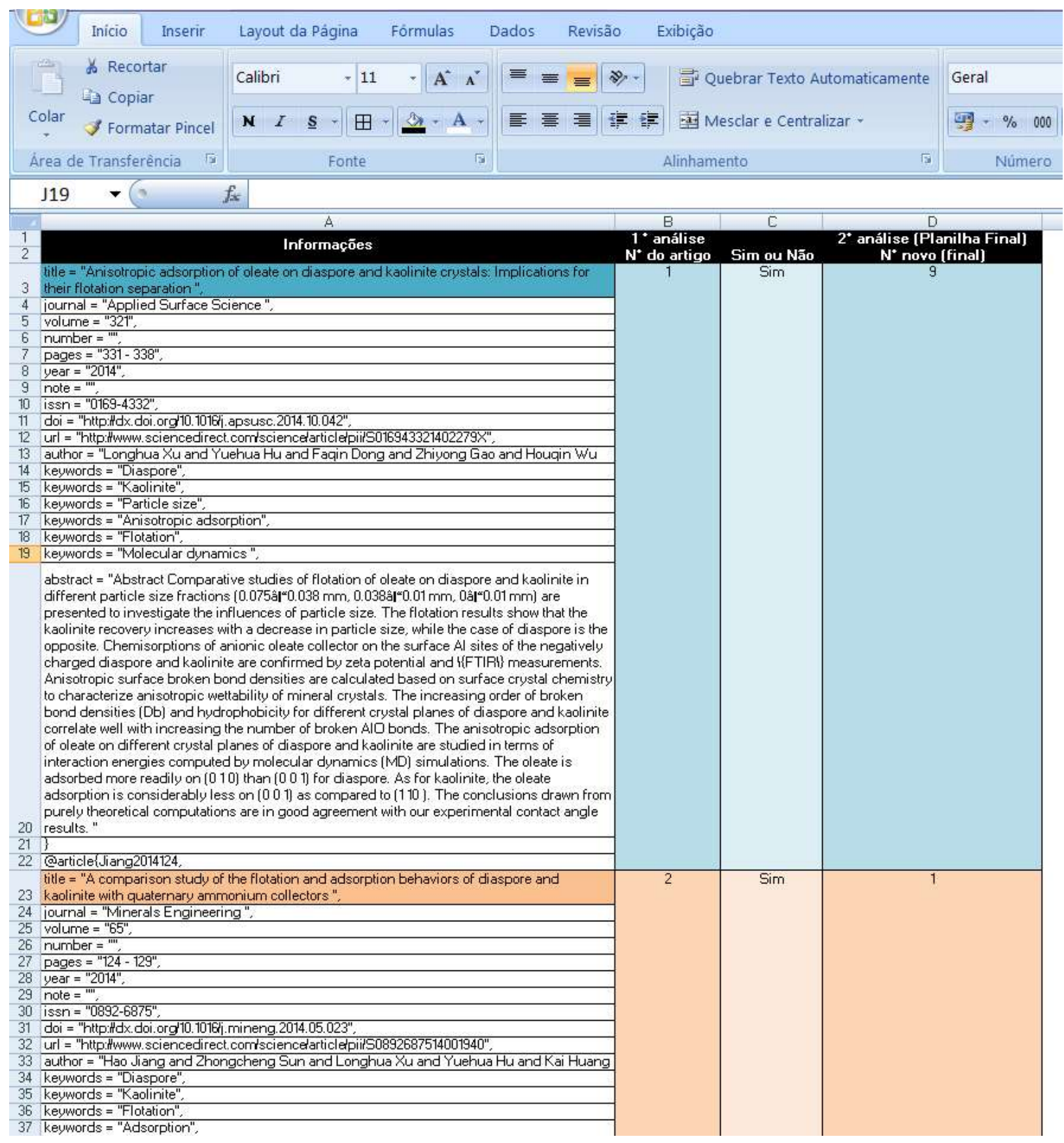

Figura 24 - Representação dos dados exportados do ScienceDirect e sua formatação em planilha Exel (elaboração própria) 
$\mathrm{Na}$ figura 25 numeraram-se os 39 artigos que estão de acordo com o objetivo da pesquisa, coluna B, e para cada artigo adicionou-se os itens: Nome do artigo, onde que conseguiu, ano, revista, palavras chave, minerais envolvidos e reagentes empregados.

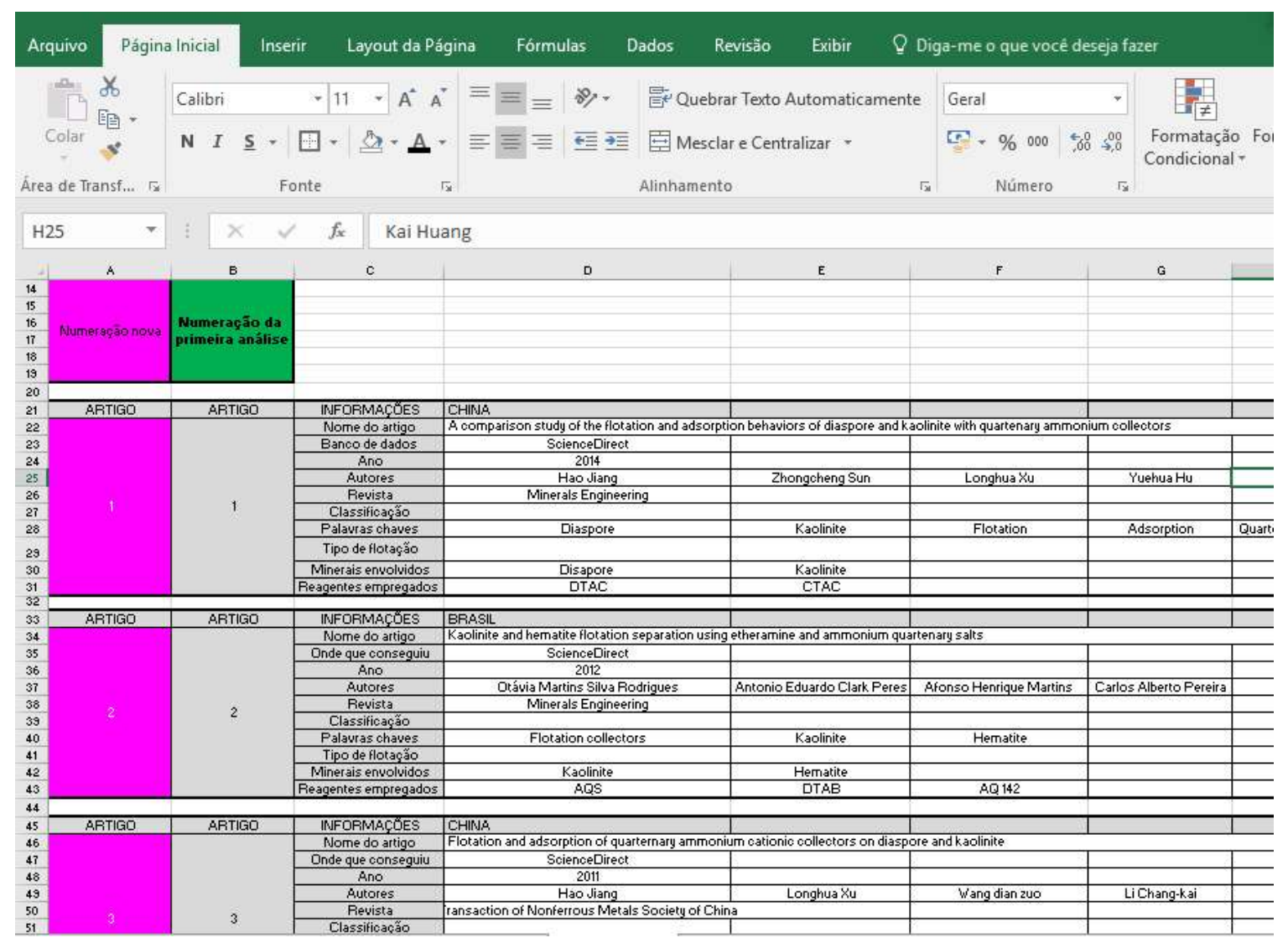

Figura 25 - Representação dos dados exportados do ScienceDirect e sua formatação na planilha Exel para os artigos que estão de acordo com o objetivo da dissertação (elaboração própria)

Para facilitar a identificação dos reagentes empregados no processo de flotação foi criada uma nova planilha (Figura 26). Os tensoativos empregados nos estudos de flotação de caulinita foram classificados conforme os artigos que os referidos são citados como agente coletor. 


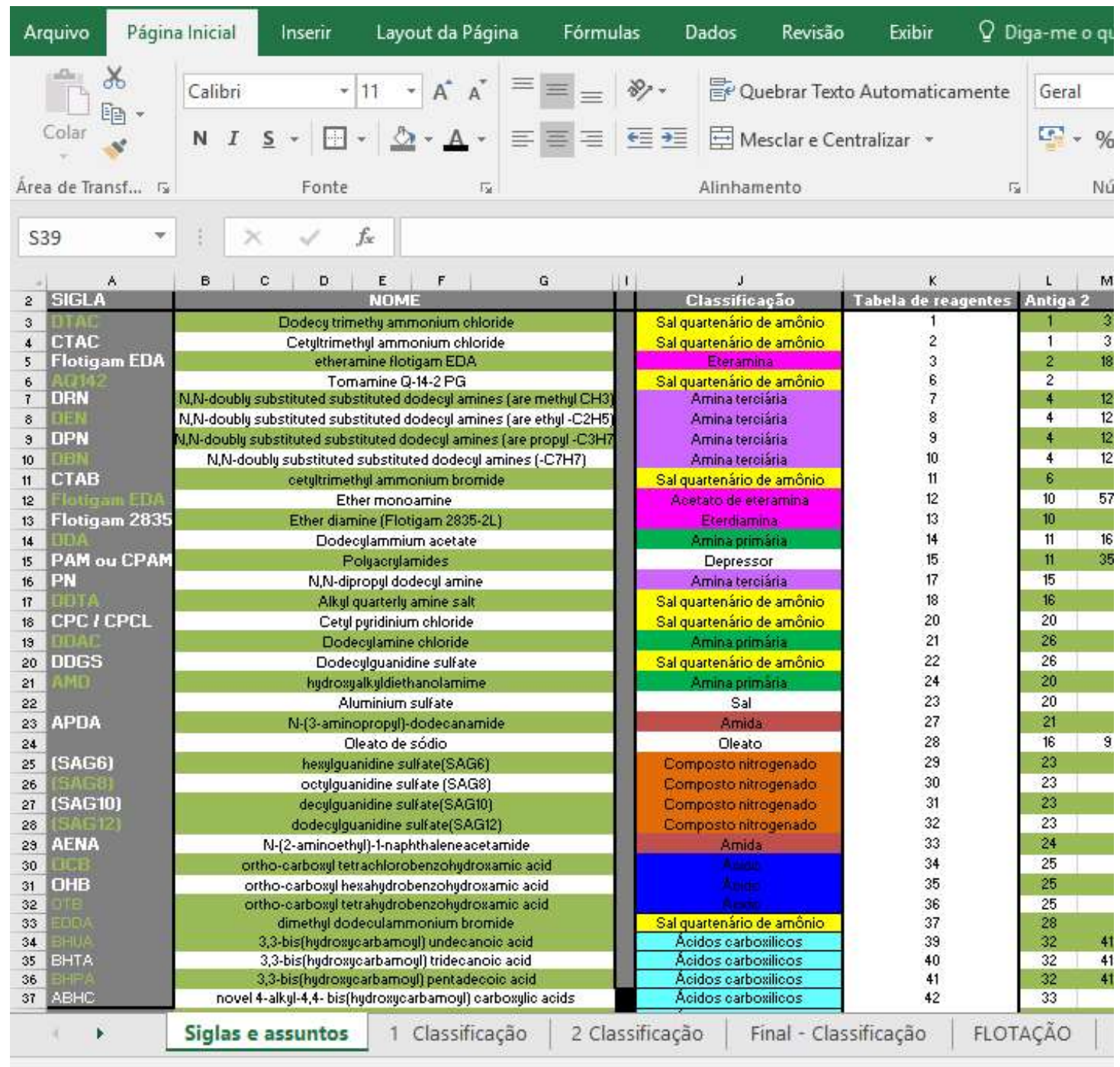

Figura 26 - Planilha com a identificação de todos reagentes empregados nos artigos, siglas e nomes por extenso (elaboração própria)

Após a leitura dos 39 artigos, a planilha da figura 27 foi formulada com o intuito de estruturar e visualizar os seguintes itens dos artigos da dissertação: reagentes, minerais, $\mathrm{pH}$ de flotação e os métodos mais aplicados no processo de flotação de caulinita. 


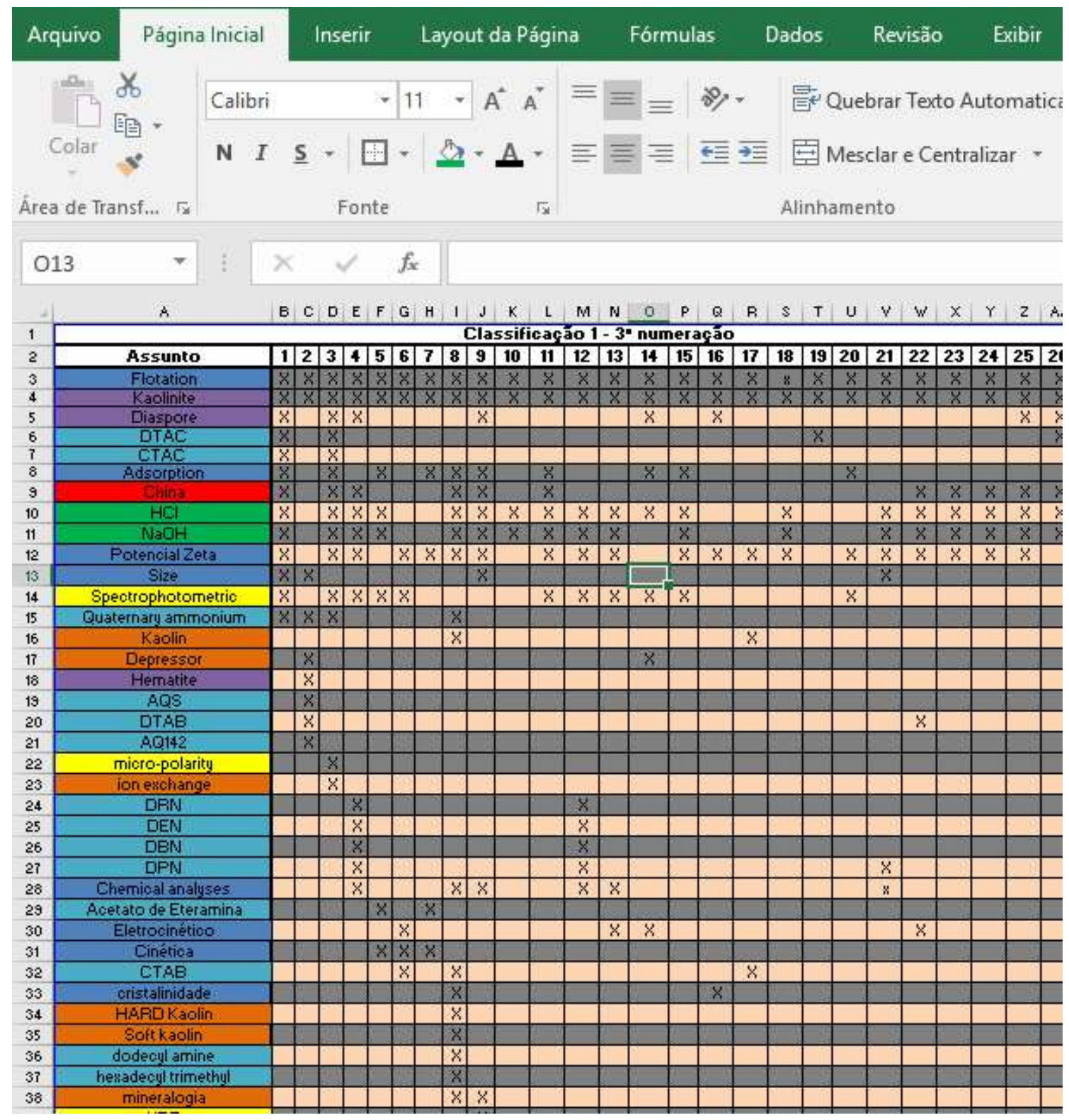

Figura 27 - Planilha com os métodos, minerais e reagentes empregados em todos os artigos do estudo (elaboração própria)

Com o auxílio das palavras-chave foi possível classificar as associações de termos que mais aparecem nos estudos sobre flotação de caulinita (Figura 28). Nessa etapa as palavras foram organizadas por artigo e verificado quantas vezes cada uma é citada. 


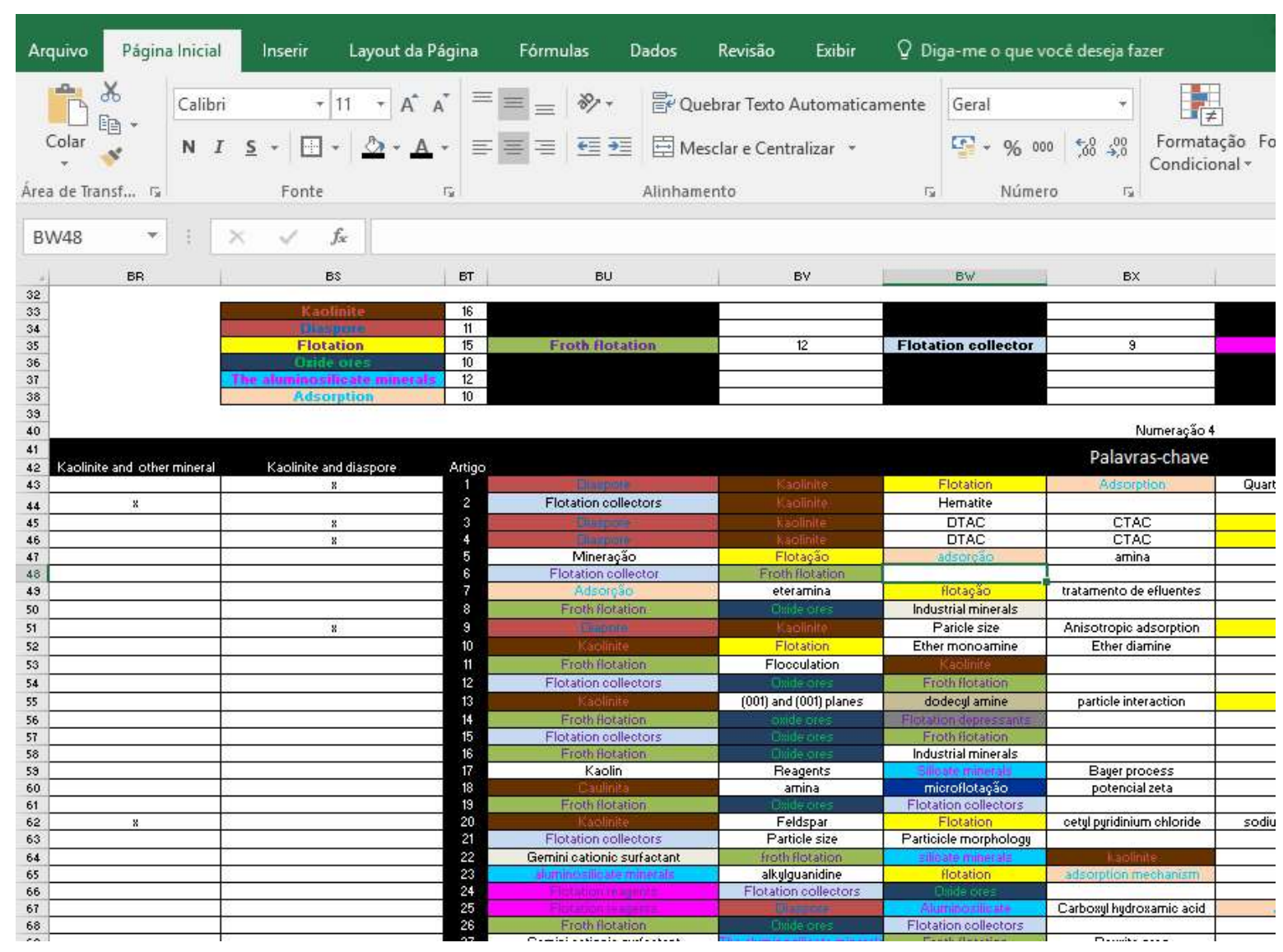

Figura 28 - Planilha com as palavras-chave mais utilizadas nos artigos de flotação de caulinita (elaboração própria)

Foi realizada uma pesquisa de citações para verificar quais são os artigos da amostra mais citados em trabalhos multidisciplinares, ou seja, trabalhos que envolvem ou não o assunto "flotação de caulinita". A ferramenta de busca escolhida foi o número de citações por artigo do próprio banco de dados da Science Direct, o Scopus (Figura 29). 


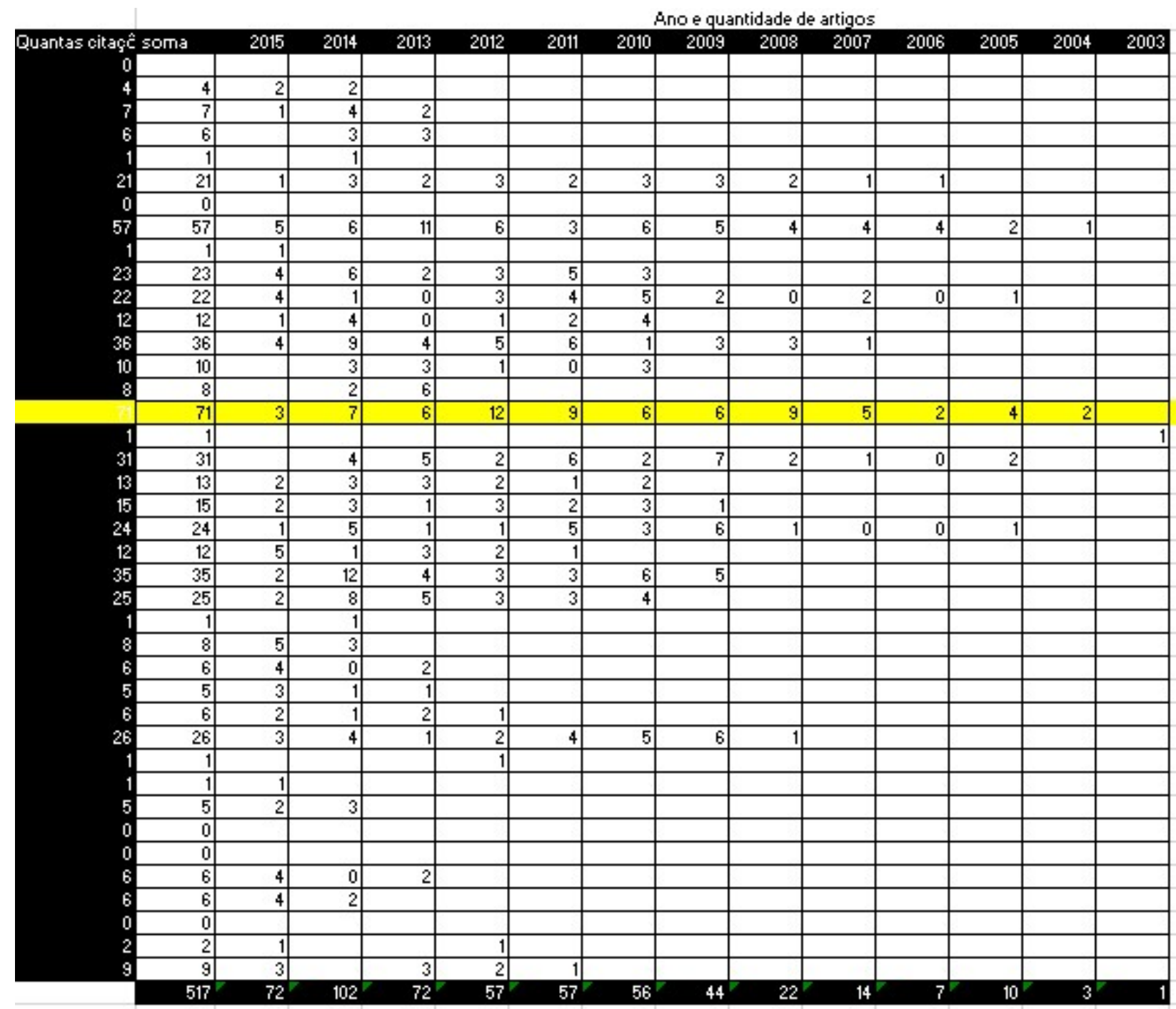

Figura 29: Citações pelo Scopus

\section{(elaboração própria)}

Seguindo a mesma linha os artigos citados pelo Scopus, em um segundo momento foi realizada uma busca de nas referências bibliográfica dos 39 artigos. Nessa nova busca, o objetivo foi verificar quais são os artigos sobre flotação de caulinita que mais influenciaram os novos artigos sobre o mesmo tema dentro do Science Direct (Figura 30). Essa busca foi realizada através da verificação individual das referências bibliográficas dos 39 artigos. 


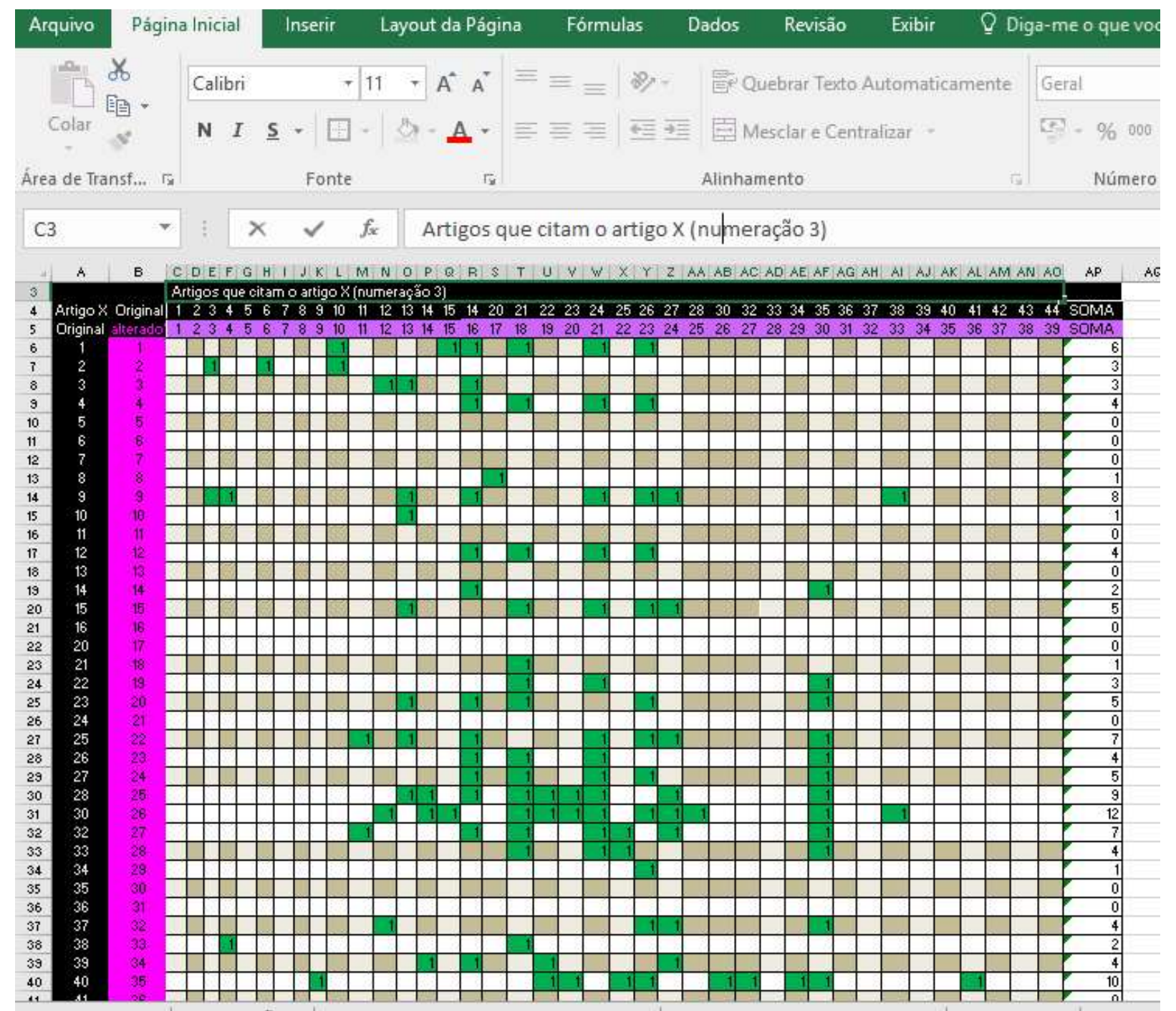

Figura 30: Planilha contendo as citações entre os 39 artigos estudados na análise bibliométrica, onde a marca verde sinaliza uma citação entre dois artigos (elaboração própria).

Em seguida da análise das citações, os resultados de todas as recuperações da flotação de caulinita e seus respectivos coletores foram agrupados em uma única tabela conforme demostra a figura 31 . 


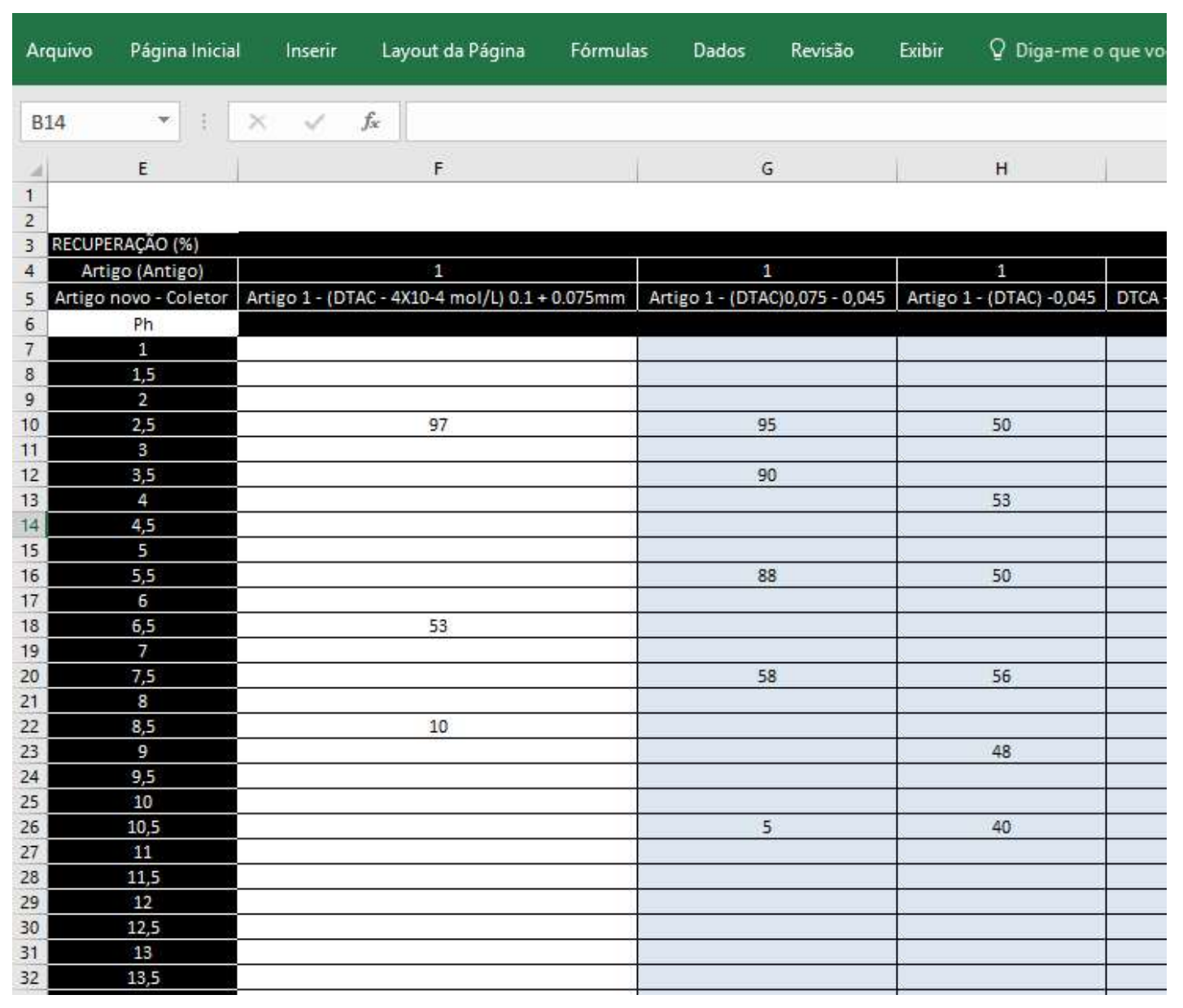

Figura 31: Planilha para verificar as recuperações dos coletores utilizados nos ensaios de flotação nos 39 artigos 


\subsection{Procedimentos para a Análise Bibliométrica}

O foco deste trabalho é a produção científica mundial. Todos os artigos foram retirados do banco de dados da Elsevier, o SciVerse ScienceDirect, disponível no endereço eletrônico http://www.sciencedirect.com/. Foram utilizadas planilhas em Excel para determinar o número de artigos elaborados por cada país, e afiliações entre países. Em propriedade dessa informação, foi possível avaliar a participação brasileira nas publicações da área, flotação de caulinita, e quais são os países que lideram o ranking de estudos.

Em uma análise mais categórica optou-se por utilizar o sistema de avaliação Qualis de avaliação da CAPES. Este sistema classifica os periódicos em oito estratos: $A 1, A 2, B 1, B 2, B 3, B 4, B 5$ e $C$. Onde $A 1$ são artigos melhores classificados. $A$ avaliação da CAPES citada nessa dissertação se refere ao grupo de Engenharias II, onde a Engenharia de Minas está incluída. Dos artigos coletados nessa dissertação, aqueles periódicos que não são avaliados pelo sistema Qualis, foram excluídos do gráfico que faz referência a esse item nos resultados e discussões.

Foi avaliada também a quantidade de publicações por ano, a quantidade de autores por artigo, a quantidade de páginas por publicação, os países onde há mais publicações, os autores mais relevantes na área atualmente e palavras-chave. Todos esses itens foram analisados estatisticamente no Software Excel. Através da leitura dos artigos foi possível classificar os artigos por pH de flotação, minerais envolvidos, métodos usados nos estudos, recuperações na flotação e artigos mais relevantes dentro dos estudos de flotação sobre caulinita.

Foram considerados os artigos que descrevam as propriedades da caulinita e os reagentes utilizados como coletores na flotação desse mineral. 


\section{RESULTADOS E DISCUSSÃO}

\subsection{Informações sobre os artigos}

Nesse capítulo são apresentados e discutidos os resultados da Avaliação Bibliométrica que foram realizados conforme descrito nos procedimentos no capítulo 2 (Metodologia).

Foram coletados ao todo 112 artigos com intuito de verificar se o artigo atenderia ou não o objetivo dessa dissertação. Desses 112 artigos, 39 periódicos foram selecionados para análise bibliométrica. Os nomes dos artigos selecionados são apresentados no anexo 1 da dissertação.

\subsection{Análise Geográfica}

Analisando apenas os artigos em que todos os autores são do mesmo país, autores de cinco países já publicaram no banco de dados ScienceDirect/ Elsevier sobre a flotação de caulinita (Tabela 2). A China lidera o ranking devido à caulinita ser abundante nos minérios bauxíticos chineses. Sem afiliações entre países foram encontrados 36 artigos. 
Tabela 2- Distribuição geográfica dos artigos produzidos por autores do mesmo país no período de 1992 a 2015 (elaboração própria)

\begin{tabular}{cc}
\hline Origem & Publicações \\
\hline China & 30 \\
Brasil & 1 \\
Austrália & 3 \\
Estados Unidos & 1 \\
Alemanha & 1 \\
\hline & 36 artigos
\end{tabular}

No gráfico 1 é apresentada a distribuição geográfica em porcentagem dos artigos produzidos por autores do mesmo país no período de 1992 a 2015, e o mapa mundial com as localizações dos respectivos países. 


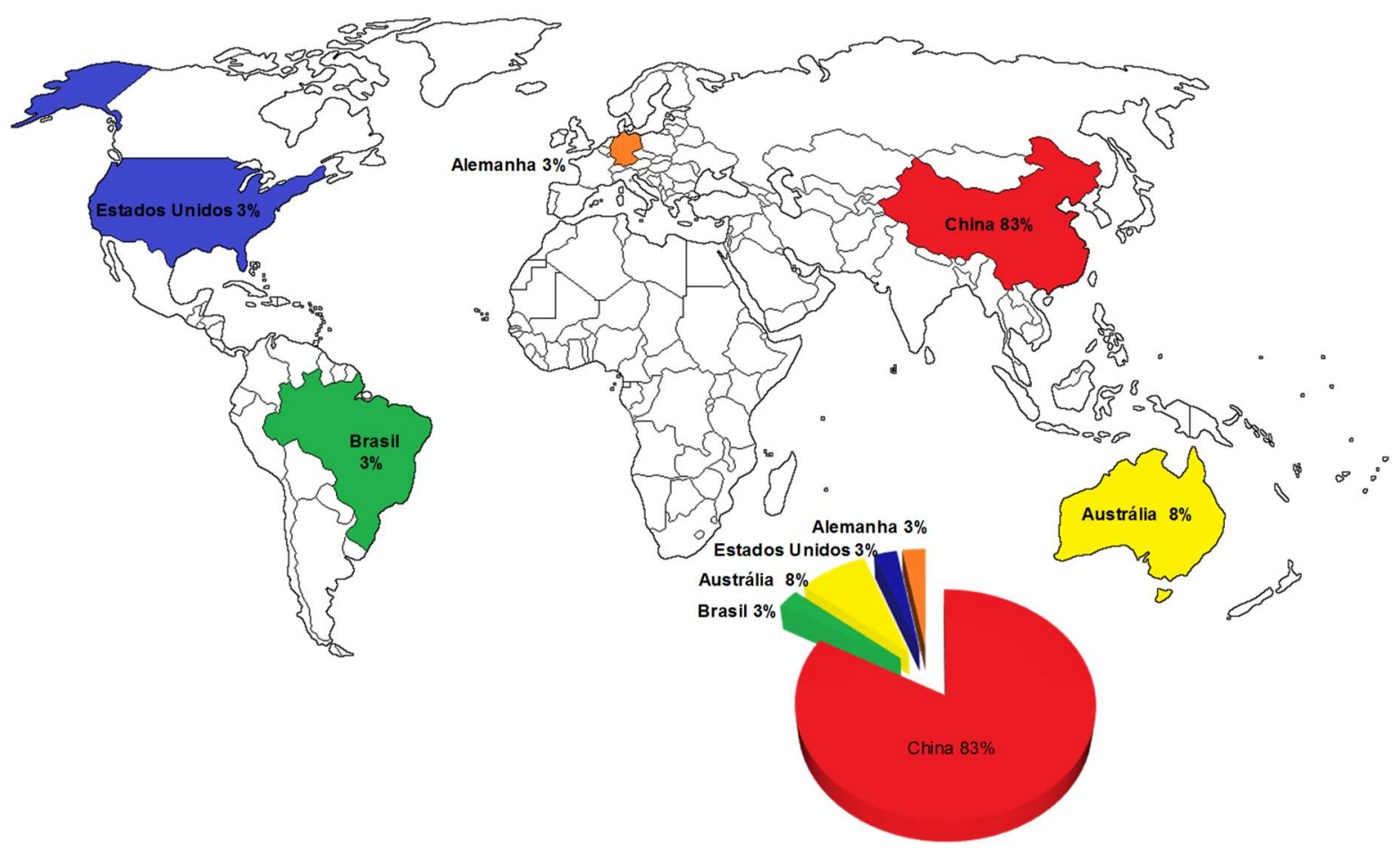

Gráfico 1 - Distribuição geográfica em porcentagem dos artigos produzidos por autores do mesmo país no período de 1992 a 2015 (elaboração própria).

Já a afiliação de mais de um país envolvidos em uma mesma publicação foram encontrados autores de três países que publicaram no Science Direct entre institutos de tecnologia mineral (Tabela 3 e Gráfico 2).

Tabela 3 - Distribuição geográfica dos artigos produzidos por autores filiados de mais de um país no período de 1992 a 2015 (elaboração própria)

\begin{tabular}{cc}
\hline Origem & Publicações \\
\hline China & 3 \\
Canadá & 2 \\
Estados Unidos & 1 \\
\hline & 3 artigos
\end{tabular}


No gráfico 2 é apresentada a Distribuição geográfica em porcentagem dos artigos produzidos por autores de mais de um país no período de 1992 a 2015, e o mapa mundial com as localizações dos respectivos países.

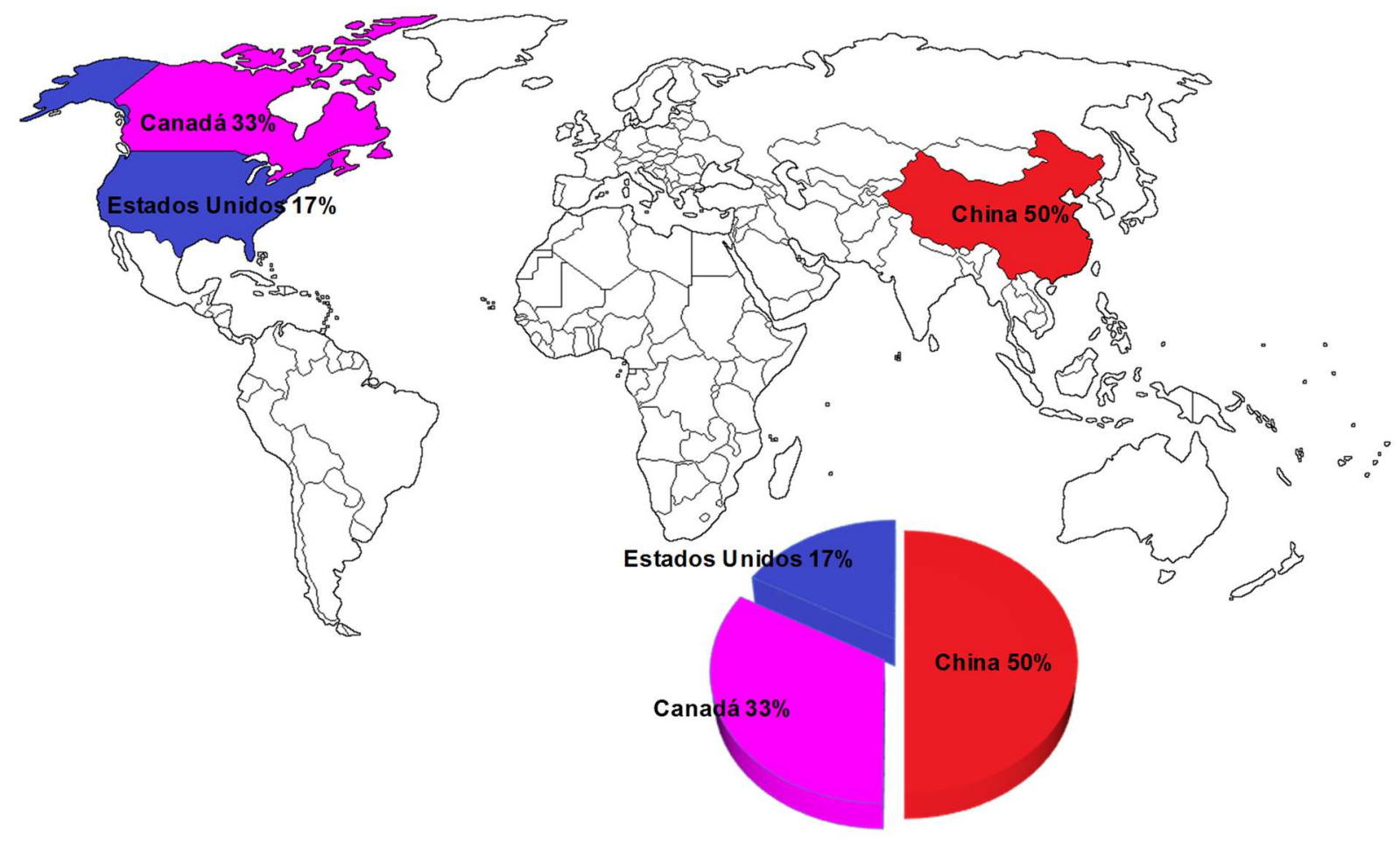

Gráfico 2 - Distribuição geográfica em porcentagem dos artigos produzidos por autores de mais de um país no período de 1992 a 2015 (elaboração própria)

Nos artigos elaborados por colaboração cientifica entre países, as parcerias ocorreram entre China - Canadá (dois artigos) e China - Estados Unidos (um artigo).

Com base nos dados apresentados nas tabelas 2 e 3, verificou-se que a China possui uma atividade colaborativa internacional e é o país que mais desenvolve pesquisa para a flotação de caulinita. Dos trinta e trez artigos publicados por autores chineses, trinta não possuem colaborações de outros países e três possuem parcerias. O Brasil possui um artigo publicado, e sem colaboração internacional. 


\subsection{Análise temporal}

$\mathrm{Na}$ análise evolutiva temporal (Gráficos 3 e 4) dos artigos pesquisados é possível constatar que antes do ano de 2003 o número de publicações sobre a flotação de caulinita era insignificante, apenas um artigo do período de 1992 até 2002.

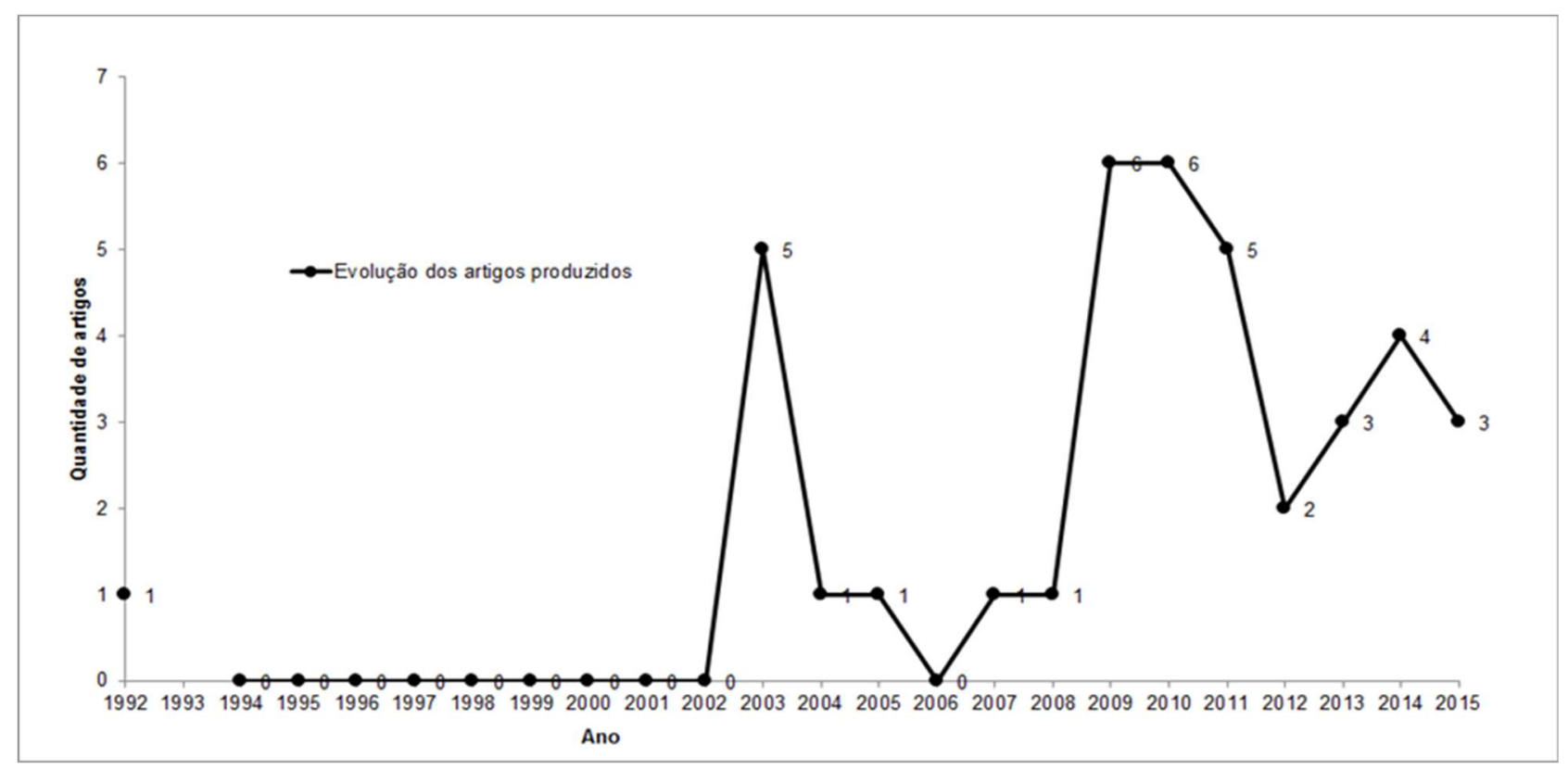

Gráfico 3- Evolução dos artigos produzidos no período de 1992 a 2015 (elaboração própria)

No ano de 2003 ocorreu um salto na quantidade de publicações sobre a flotação de caulinita. Foram ao todo cinco artigos e todos de institutos de tecnologia chinesas. Segundo o relatório "A indústria do alumínio: estrutura e tendências" do banco BNDES o preço do alumínio apresentou grande alta, entre os anos de $2003 \mathrm{e}$ 2008, principalmente pela expansão do consumo na China. Além disso, a partir do ano de 2002 segundo "O Relatório de Estudos Setoriais: Alumínio" (XAVIER, 2012) a tarifa média de energia elétrica na produção de alumínio no mundo teve um salto de 20 \$/MWh para 50 \$/MWh no ano de 2012. Neste caso, pode-se justificar este marco no aumento de publicações da comunidade científica devido ao interesse das indústrias em diminuir o teor de sílica nos minérios bauxiticos, pois a caulinita aumenta 
os custos no processo Bayer. Segundo o BNDES (sem data) no ano de 2009 em que a China passou a ser o maior produtor mundial de alumínio, 39\% da produção, ocorreu a maior quantidade de publicações (15\%) que envolveram a flotação de caulinita (BNDES, sem data).

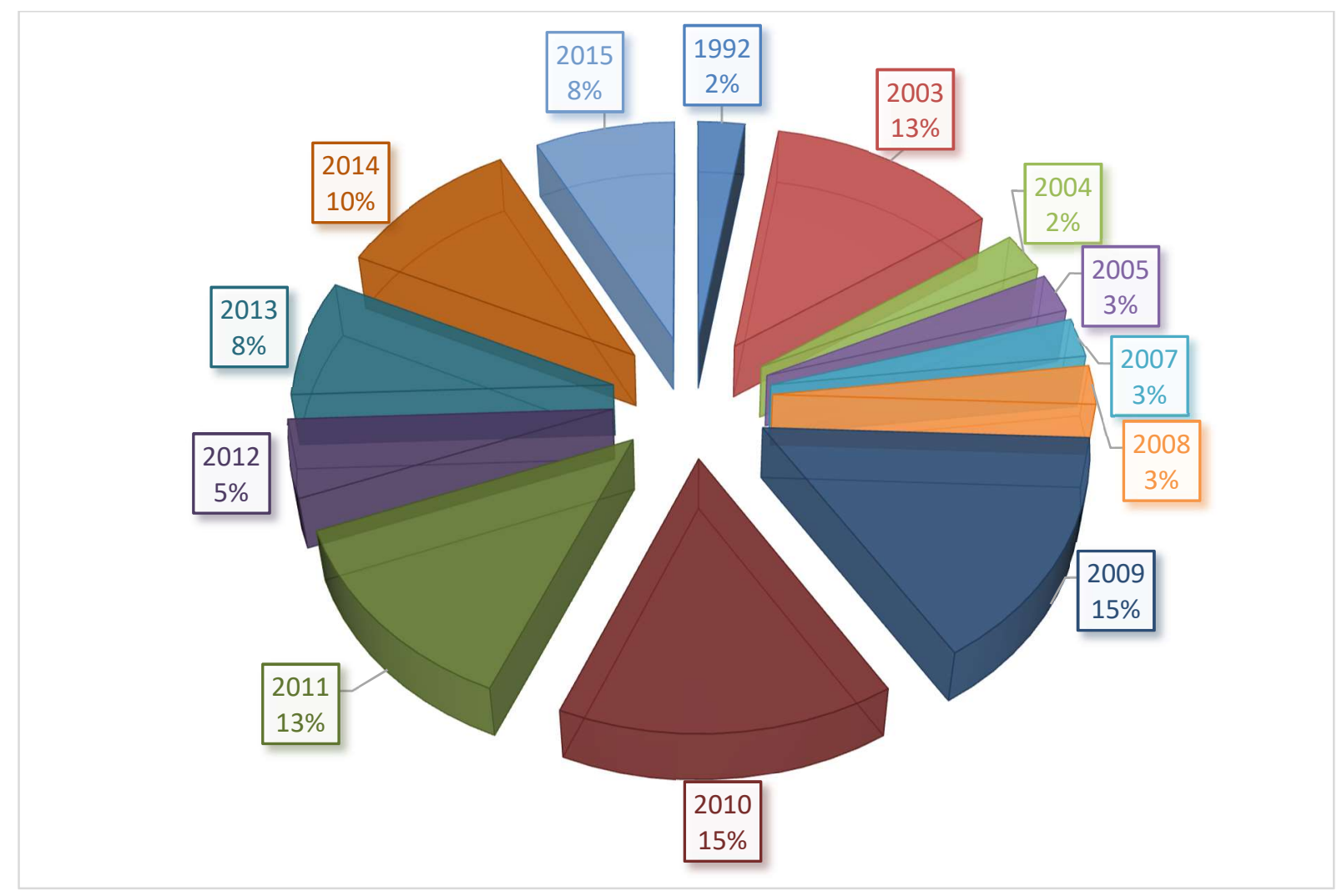

Gráfico 4 - Distribuição em porcentagem dos artigos produzidos por ano no período de 1992 a 2015 (elaboração própria)

\subsection{Análise do número de autores por artigo}

A tabela 4 foi construída com o propósito de expor a quantidade de artigos produzidos de acordo com o número de autores. Contata-se que há um predomínio de artigos produzidos por mais de um pesquisador $(97,4 \%)$. Através dos dados apresentados, verifica-se que existe colaboração científica entre os autores. E o fato 
de apenas $2,6 \%$ dos artigos terem sido elaborados por um pesquisador, indica a dificuldade de se trabalhar com o tema de flotação de caulinita individualmente.

Tabela 4 - Quantidade de artigos por números de autores

\begin{tabular}{cc}
\hline AUTORIA & QUANTIDADE \\
\hline 1 autor & 1 \\
2 autores & 2 \\
3 autores & 8 \\
4 autores & 9 \\
5 autores & 13 \\
6 autores & 3 \\
7 autores & 3 \\
\hline Total & 39
\end{tabular}

O número máximo de autores encontrados foi de sete, e o mínimo foi de um. Os autores com as maiores contribuições na área científica da flotação de caulinita são os chineses: Hu Yuehua com treze artigos, Hong Zhong com doze publicações, Liu Guangyi com onze artigos. No Brasil, Otávia Martins Silva Rodrigues e o Prof. Antonio Eduardo Clark Peres foram os únicos brasileiros que publicaram sobre flotação de caulinita em artigos presentes no banco de dados da Elsevier, o SciVerse ScienceDirect.

No período referido do presente trabalho o gráfico 5 apresenta a quantidade de artigos por números de autores em porcentagem, sendo que 33\% dos artigos estão na faixa de cinco autores por publicação. 


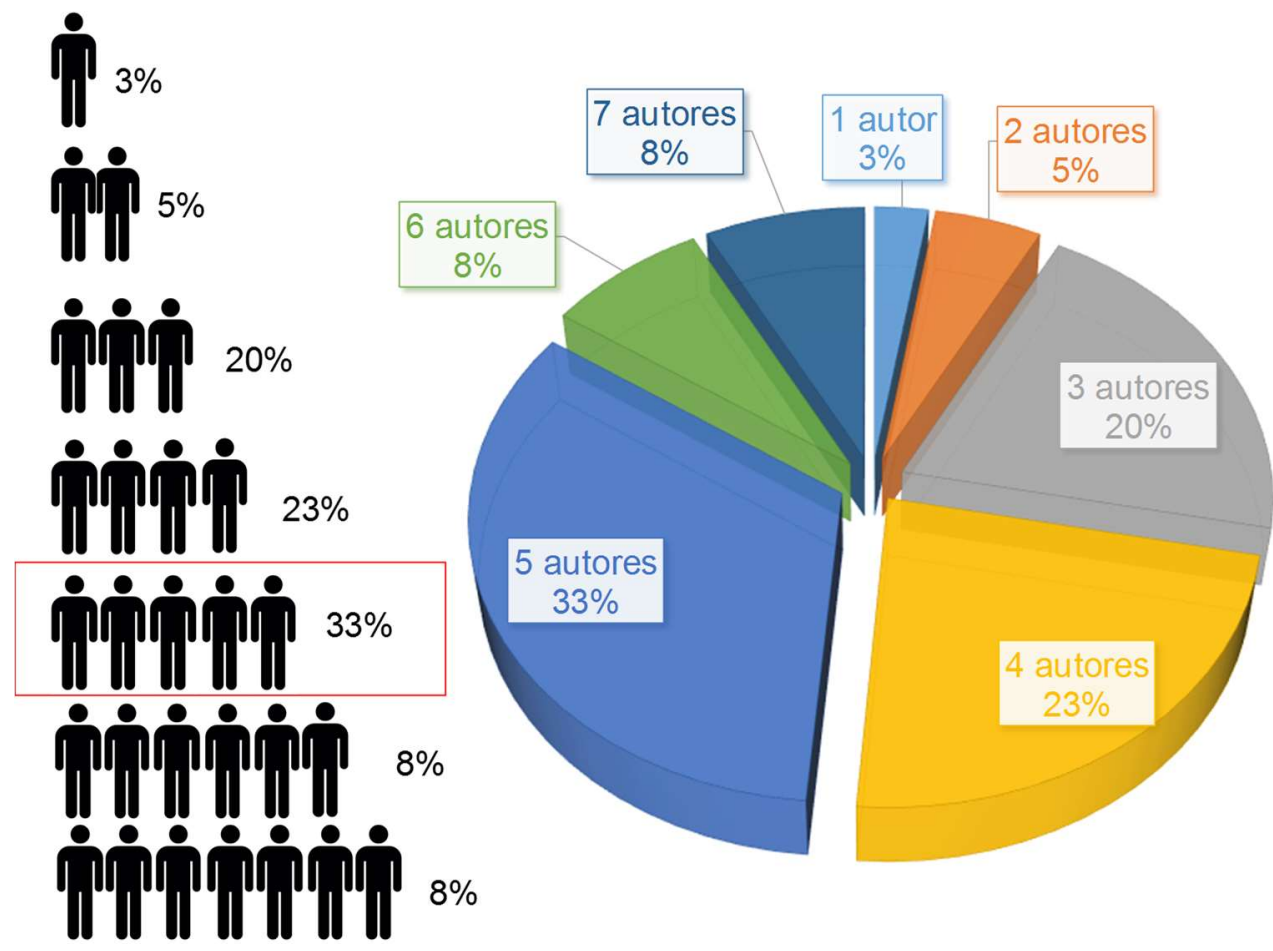

Gráfico 5 - Quantidade de artigos por números de autores em porcentagem no período de 1992 a 2015 (elaboração própria)

\subsection{Análise dos artigos de acordo com o número de páginas}

O gráfico 6 quantifica o número de páginas de cada um dos estudos da dissertação. 


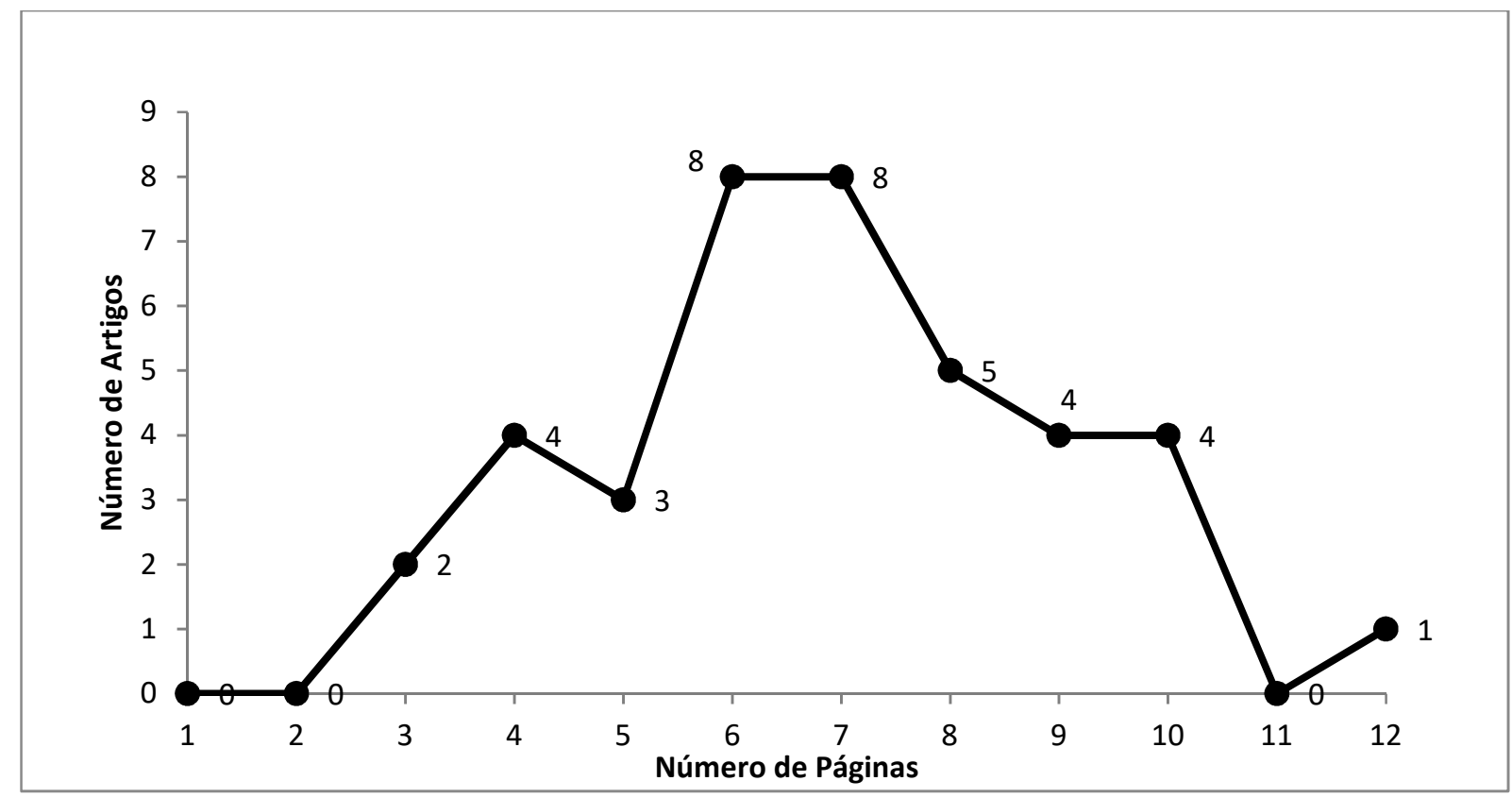

Gráfico 6 - Número de artigos por número de páginas (Elaboração própria)

O maior número de estudos se concentra na faixa de seis e sete páginas por artigo. Apenas quatro artigos foram escritos com de 10 páginas, o que corresponde a apenas $10 \%$ da amostra. E um artigo com 12 páginas (Gráfico 7 ). Estes últimos trabalhos foram mais extensos devido às seguintes metodologias, por exemplo: três trabalham com a flotação de mais de três minerais, um trabalha com vinte diferentes sais quartanários de amônio e um caracteriza os planos mineralógicos da caulinita além de estudos sobre a flotação de caulinita utilizando um coletor. 


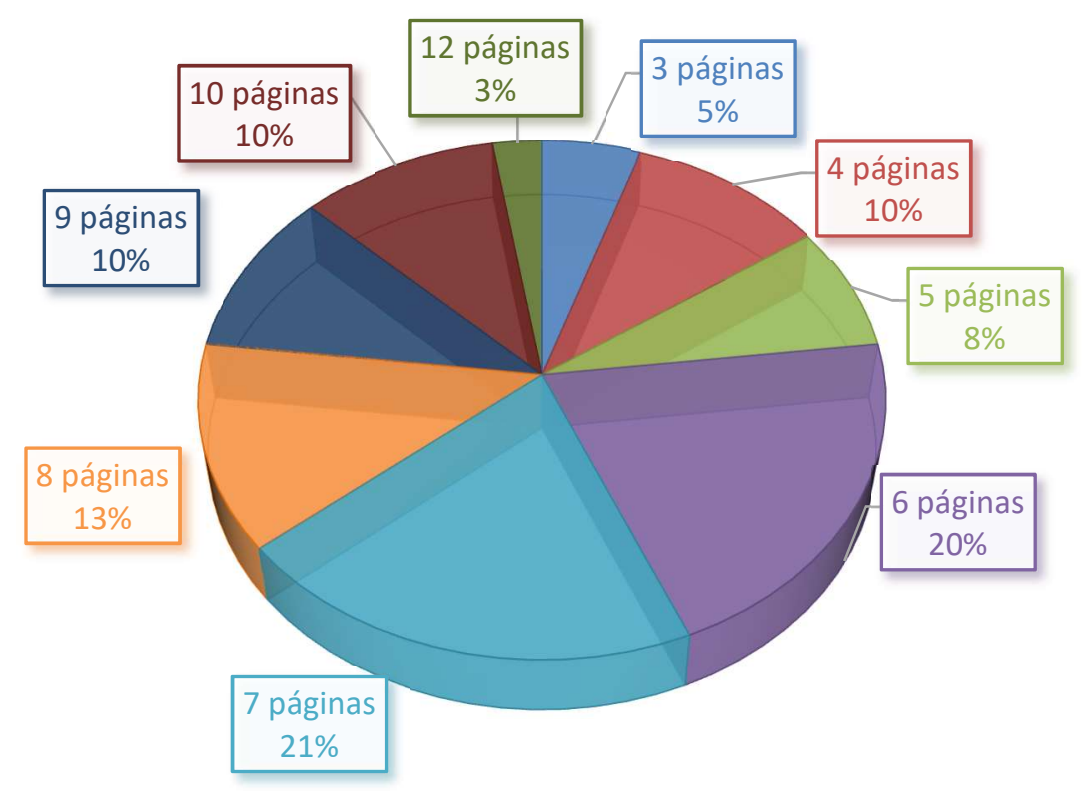

Gráfico 7 - Número de artigos por número de páginas em porcentagem (Elaboração própria)

\subsection{Análise dos artigos por: periódicos e classificação CAPES}

Conforme explicado no item Procedimentos para Análise Bibliométrica do capítulo Metodologia, a análise dos artigos por periódicos foi realizada em uma amostra de 39 artigos publicados em 8 periódicos.

Foram encontrados vinte e dois artigos no periódico Minerals Engineering, principal revista na área de mineração, correspondendo a $56 \%$ de todas as publicações dessa análise bibliométrica (Gráfico 8). Um artigo (3\% das publicações) foi publicado no jornal Separation and Purification Technology. Essa última revista é destinada para novos métodos de separação e purificação para engenharia química e ambiental. Três artigos ( $8 \%$ das publicações) foram publicados no periódico Mining Science and Technology. Já nos periódicos Applied Surface Science, International Journal of Mineral Processing e Separation and Purification Technology foram publicados dois artigos em cada revista, cada periódico 
corresponde a $5 \%$ no gráfico abaixo. Seis artigos, equivalendo a $15 \%$ do gráfico no periódico Transaction of Nonferrous Metals Society of China. Foi publicado apenas um artigo no periódico (2,5\%) Hydrometallurgy.

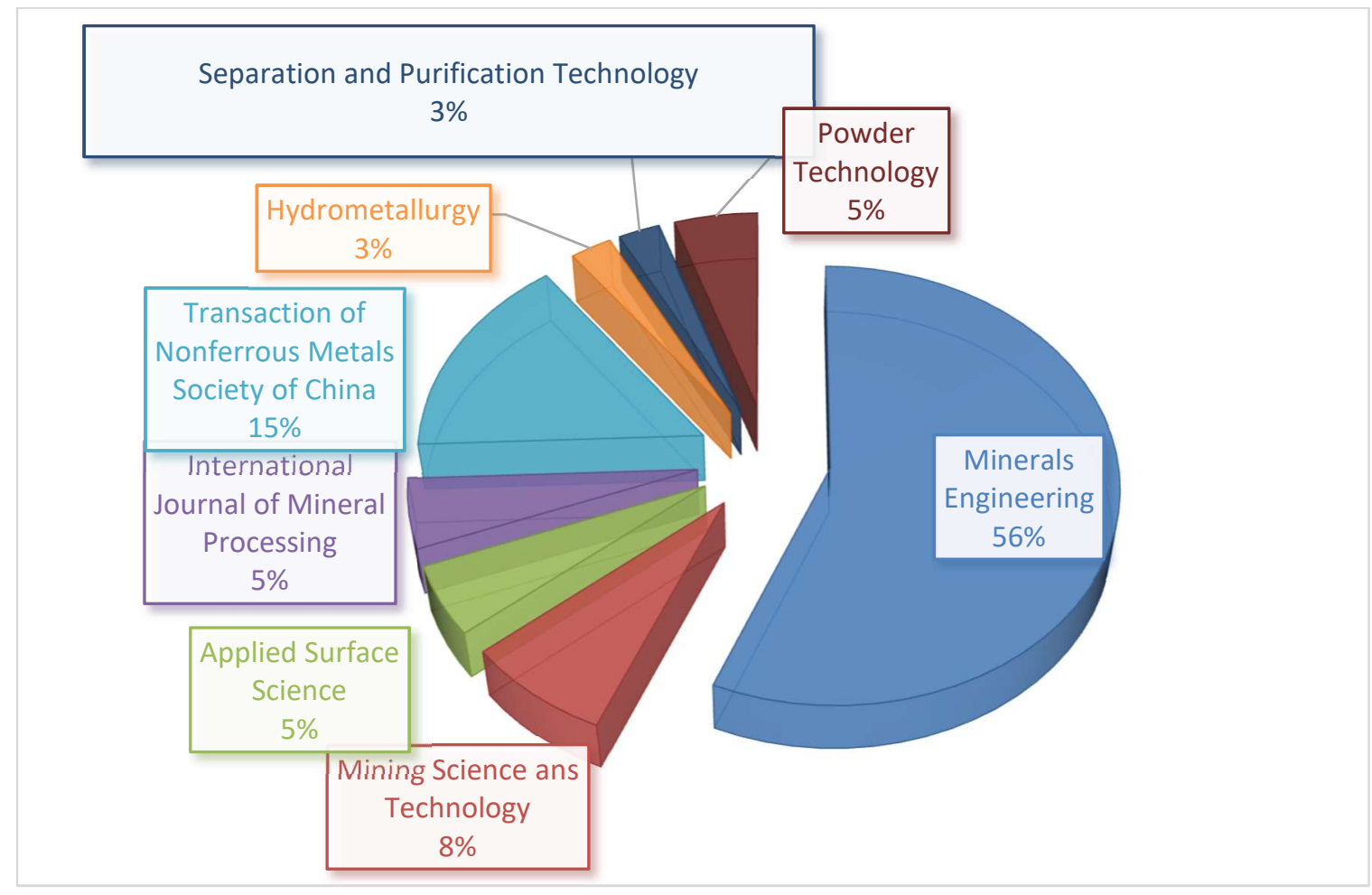

Gráfico 8 - Número de artigos por periódicos (Elaboração própria)

Dos trinta e nove artigos considerados nessa dissertação, nove artigos não são avaliados pelo sistema Qualis. Os trinta artigos em que seus periódicos possuem avaliação interdisciplinar da CAPES, todos são classificados no estrato A1, ou seja, artigos com a mais alta classificação no grupo Engenharias II. Os periódicos $A 1$ são: Minerals Engineering, Applied Surface Science, International Journal of Mineral Processing, Hydrometallurgy, Separation and Purification Technology e Powder Technology. Nos outros estratos do Qualis não foram encontrados artigos que fazem referência à flotação de caulinita. 


\subsection{Análise dos artigos através de palavras-chave}

Os 39 artigos juntos possuem ao todo 180 palavras-chave. As palavras-chaves nos artigos são fundamentais, pois descrevem o tema ou assunto do texto. São também uma ferramenta importante de busca, pois representam o contexto do artigo. Desta forma, foi realizada uma análise em todas as palavras-chave dos artigos considerados. O gráfico 9 apresenta a quantidade de palavras-chave por artigo, e verificou-se que: esses possuem uma média de 4,5 palavras-chave por artigo, sendo o mínimo de 2 palavras e o máximo de 8 palavras.

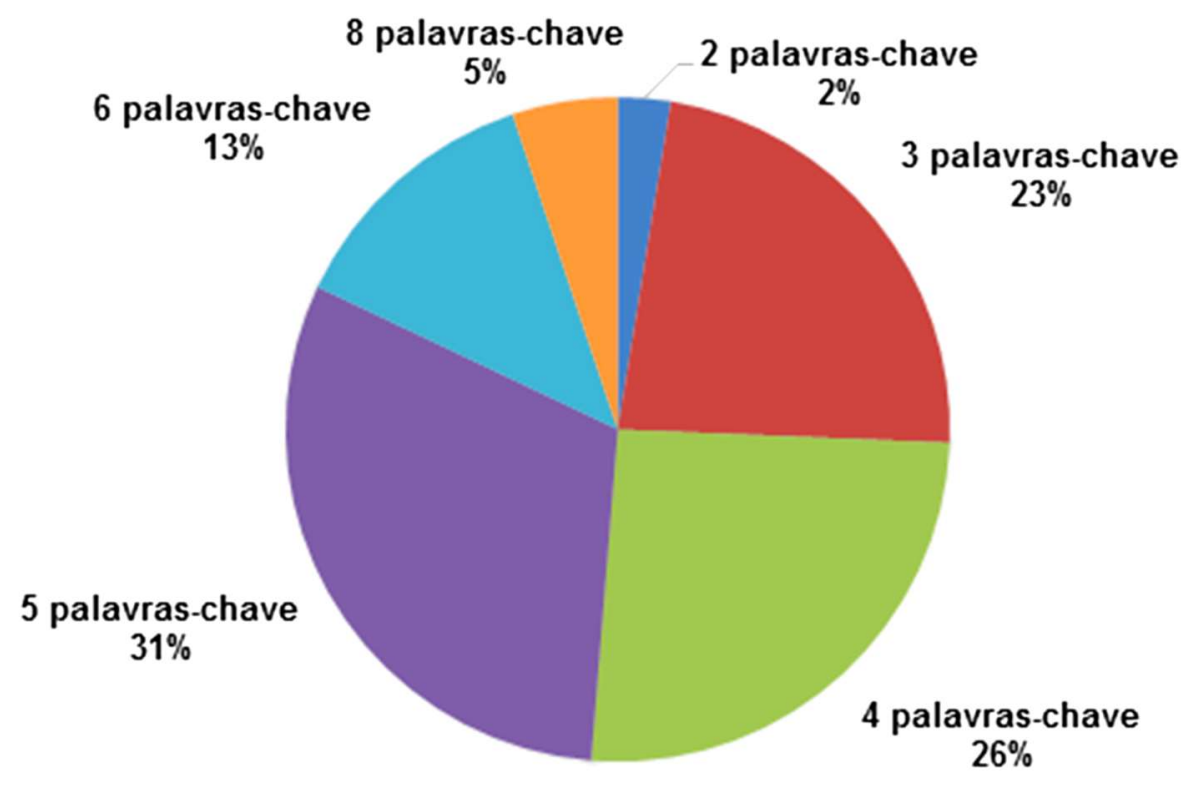

Gráfico 9 - Quantidade de palavras-chave por artigo (Elaboração própria)

Uma das grandes dificuldades dessa dissertação foi selecionar os artigos que comporiam a análise bibliométrica. Essa dificuldade justifica-se pelo fato de que nem sempre a caulinita está presente nas palavras-chave. Conforme tabela 5 e gráfico 10 é possível observar que em apenas 15 artigos o termo "caulinita" está presente nas palavras-chave. Como já descrito, os termos "Aluminossilicatos", "Minérios oxidados" e "diásporo" são frequentemente encontrados nos artigos em virtude de os chineses 
serem os maiores produtores de alumínio no mundo, e a caulinita é o rejeito no processo de flotação reversa do diásporo.

Tabela 5 - Minerais encontrados nas palavras-chave dos 39 artigos (Elaboração própria)

\begin{tabular}{cc}
\hline Minerais envolvidos & Quantidade \\
\hline Nenhum mineral & 2 \\
Pirofilita e Gibbsita & 1 \\
Diásporo & 2 \\
Aluminossilicatos & 3 \\
Minérios oxidados & 9 \\
Caulinita e Aluminossilicatos & $\mathbf{2}$ \\
Diásporo e Aluminossilicatos & 7 \\
Caulinita & $\mathbf{6}$ \\
Caulinita e Feldspato & $\mathbf{1}$ \\
Caulinita e Hematita & $\mathbf{1}$ \\
Caulinita e Diásporo & $\mathbf{5}$ \\
\hline Artigos & 39 \\
\hline Com o mineral de Caulinita & $\mathbf{1 5}$ \\
\% & $\mathbf{3 8 , 5}$ \\
\hline
\end{tabular}

No gráfico 10 é possível observar a distribuição em porcentual dos minerais citados nas palavras-chave dos 39 artigos. Apenas em $39 \%$ das vezes a caulinita é citada nos artigos como palavra-chave. 


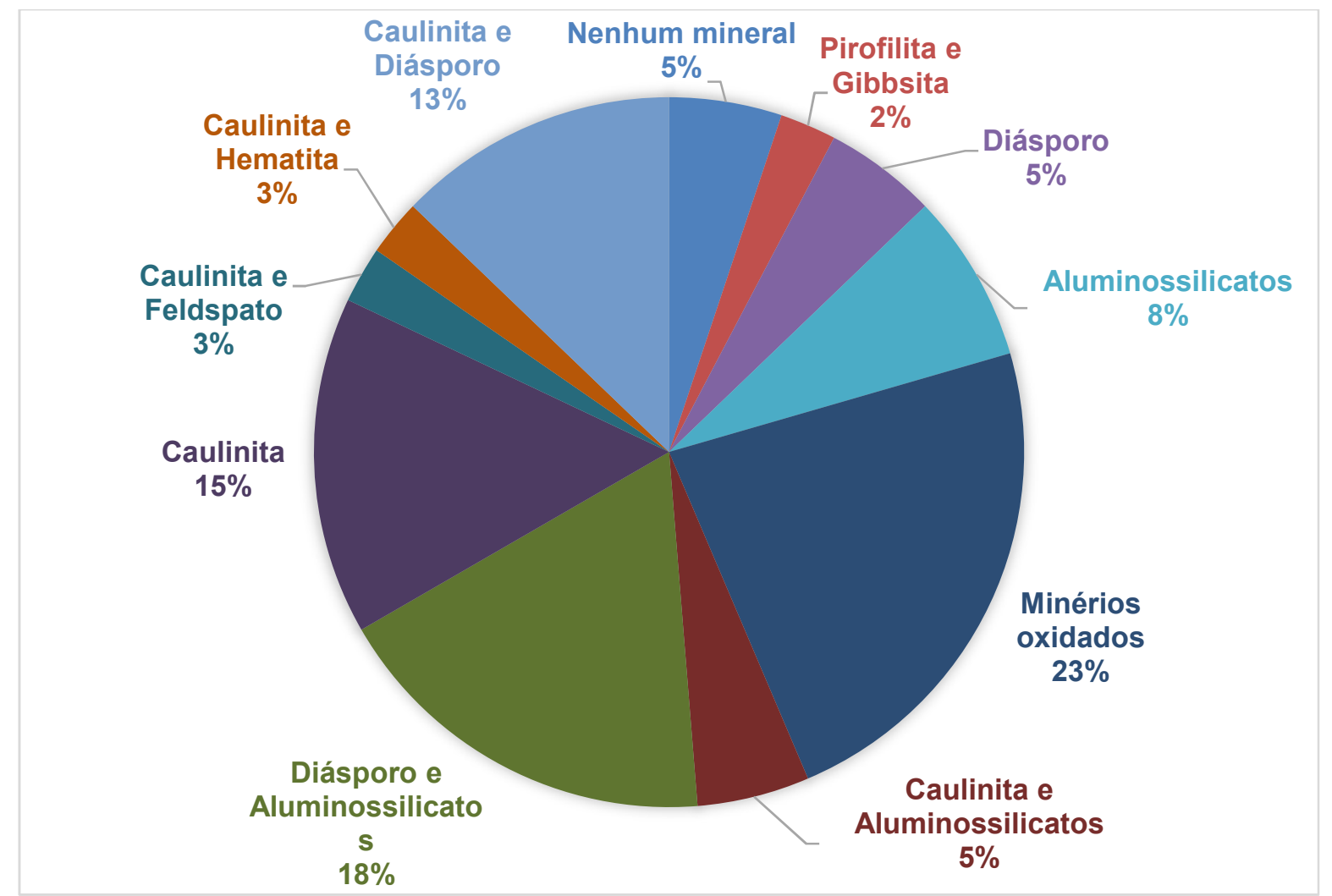

Gráfico 10 - Minerais citados nas palavras-chave dos 39 artigos e sua distribuição em porcentual (Elaboração própria)

Foram avaliadas também as palavras-chave mais frequentes nos 39 artigos. De todas as 180 palavras-chave, 12 se destacaram ou pela quantidade de vezes que apareceram nos artigos, 100 ocorrências, ou pela sua importância dentro da flotação. O gráfico 11 se destacam o termo "flotação", "flotação por espuma", "caulinita", "diásporo", "minérios oxidados", "aluminossilicatos" e "adsorção". 


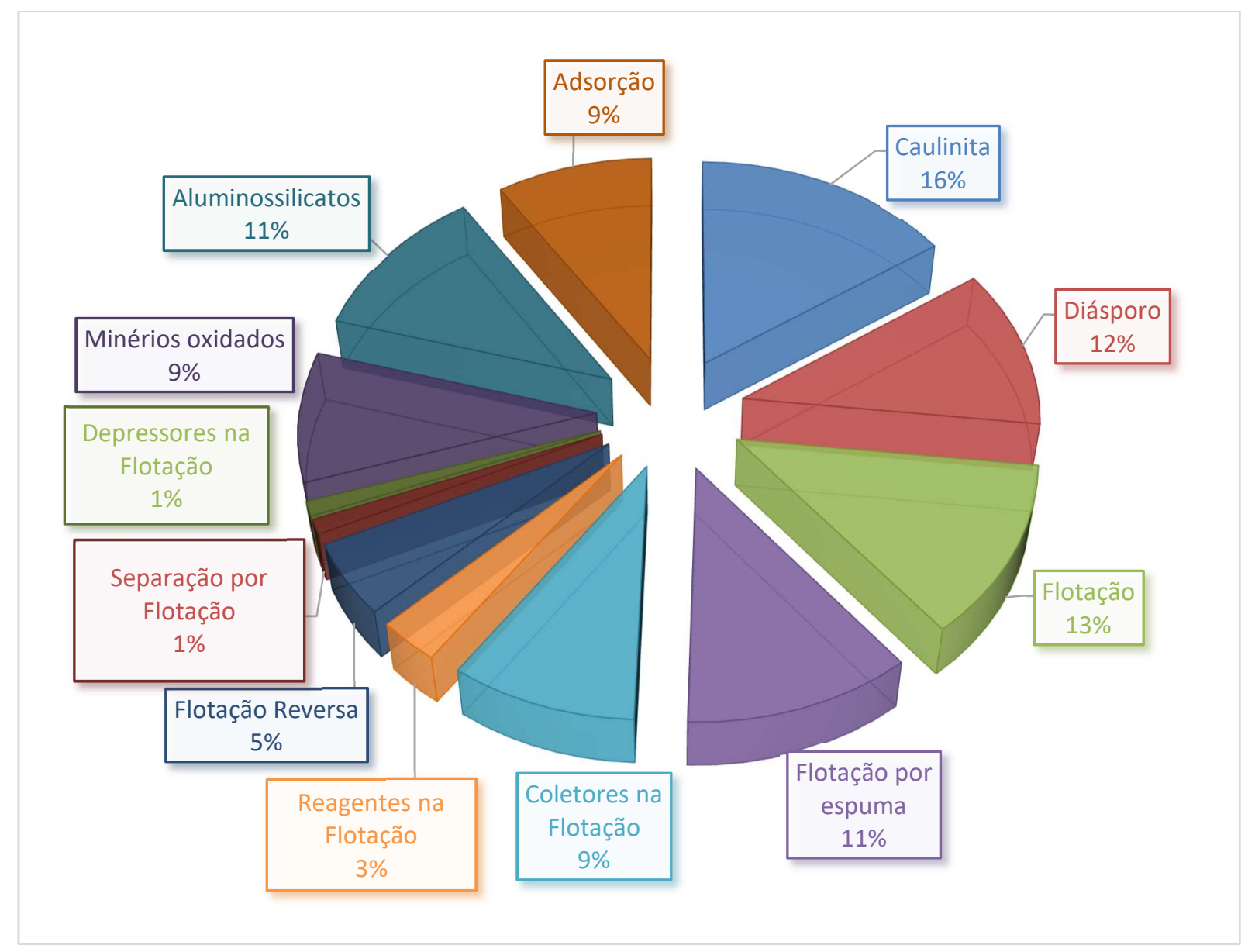

Gráfico 11 - Palavras-chave mais frequentes nos 39 artigos (Elaboração própria)

\subsection{Minerais envolvidos na flotação de caulinita}

Através de uma leitura e análise dos artigos foi possível classificar os minerais que aparecem no corpo do texto junto com a flotação do mineral de caulinita. O gráfico 12 foi desenvolvido porque não são todos os minerais que aparecem nas palavraschave e são estudados nos artigos da amostra.

Conforme o gráfico 12 observa-se que $23 \%$ o mineral de caulinita é estudado individualmente, sem a presença de minerais secundários. Já $31 \%$ dos artigos realizam testes de flotação reversa do diásporo onde a caulinita é caracterizada como mineral de rejeito. Os estudos com os minerais caulinita, ilita e pirofilita (juntos) 
representam $15 \%$ no gráfico. Caulinita, diásporo e ilita representam $13 \%$ da amostra do estudo. Caulinita, diásporo, ilita e pirofilita ocupam $8 \%$ dos minerais trabalhos. Apenas $3 \%$ dos artigos utilizam caulinita junto com a hematita e $3 \%$ caulinita com feldspato.

A participação do diásporo (hidróxido de alumínio), da pirofilita (silicato de magnésio hidratado) e da ilita (argilomineral) nos artigos de flotação de caulinita é em virtude de que esses minerais estão presentes nos depósitos de bauxita na China. No caso da ilita, por esse mineral pertencer ao grupo de argilominerais, suas características de superfície são semelhantes às da caulinita, fato que dificulta na flotação de caulinita.

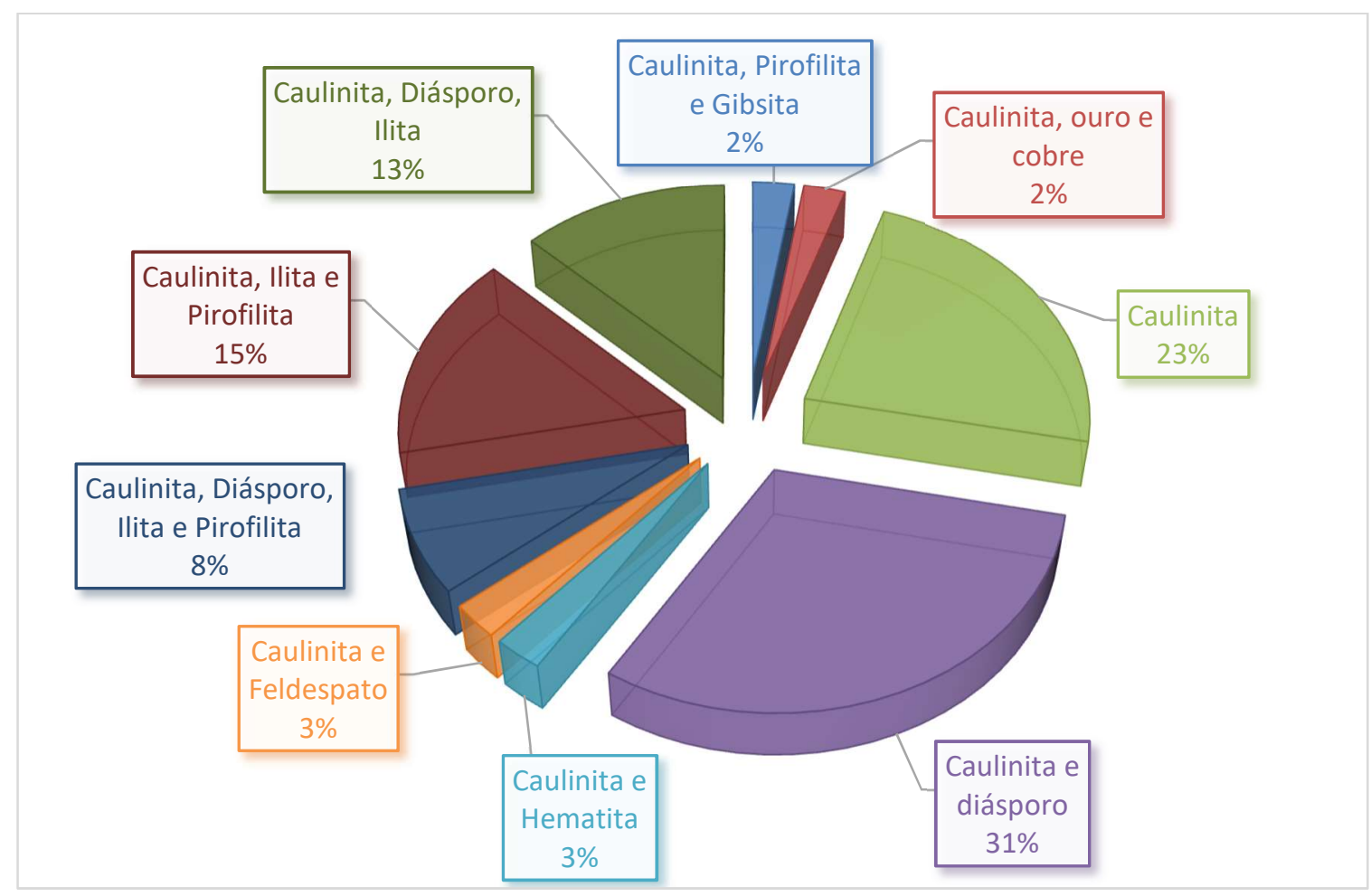

Gráfico 12- Minerais envolvidos nos 39 artigos (Elaboração própria) 


\subsection{Análise dos métodos mais significativos utilizados nos artigos}

Essa análise foi realizada através dos métodos usados nos 39 artigos. Foram encontrados 12 métodos mais representativos, métodos esses que são importantes para compreender os fenômenos físico-químicos na flotação. Como já descrito na revisão bibliográfica, a interação entre aminas graxas e silicatos tem sido exaustivamente estudada por métodos indiretos, isto é, através de medidas de ângulo de contato, potencial zeta, densidade de adsorção e resposta à microflotação.

Através do gráfico 13 observa-se que os métodos mais representativos da amostra são: potencial zeta (28\%), métodos de caracterização mineralógica $(31 \%)$ e estudos de adsorção (14\%).

De acordo com Leja (1982), toda partícula sólida imersa num meio aquoso adquire uma dupla camada elétrica cujo limite com a solução é o Plano de Cisalhamento. O potencial Zeta de uma partícula é a diferença de potencial elétrico entre o plano de cisalhamento e um ponto no seio da solução (infinitamente afastado de tal superfície). Como o existe um consenso geral de que o mecanismo de adsorção de aminas graxas em silicatos depende do $\mathrm{pH}$ do meio, os testes de potencial zeta determinam o ponto isoelétrico do mineral. Já os testes de adsorção verificam a intensidade de adsorção do coletor na superfície mineral e auxiliam a compreender o mecanismo de adsorção das moléculas do coletor na superfície da caulinita. A espectrofotometria é um método que, através de uma radiação absorvida ou transmitida analisa os aspectos físico-químicos da amostra, fornecendo uma análise química do material.

Observa-se também através do gráfico 13 que testes de ângulo de contato que determina a hidrofobicidade do mineral e constata se o coletor foi capaz de transformar seu caráter hidrofílico em hidrofóbico foi pouco utilizado, representando apenas $3 \%$ dos testes utilizados nas pesquisas. 


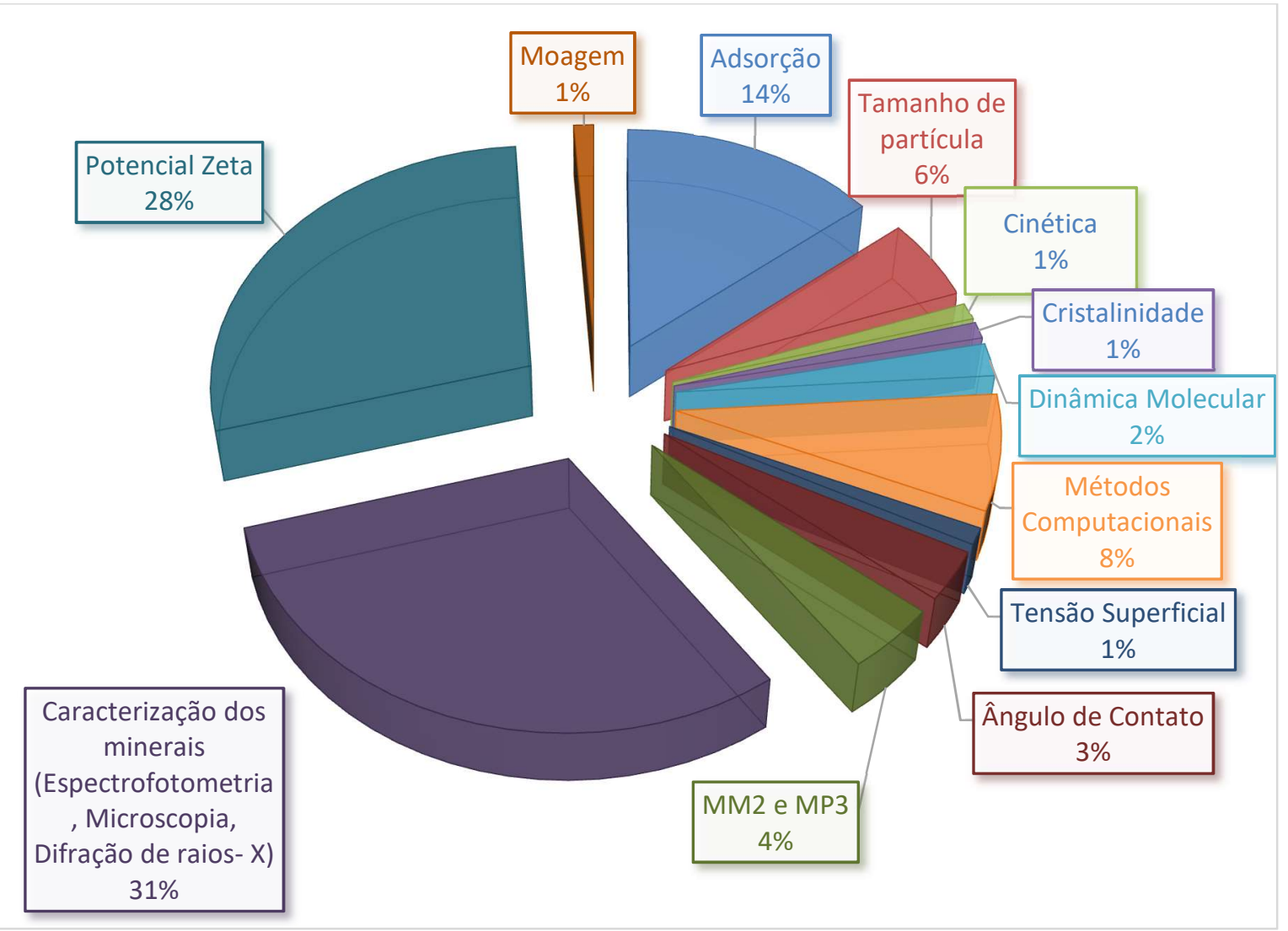

Gráfico 13 - Métodos mais utilizados nos artigos (Elaboração própria)

\subsection{Citações pelo Scopus}

Uma das ferramentas utilizadas na análise bibliométrica é a citação. A análise de citação baseia-se no princípio de que autores citam artigos que consideram importantes no desenvolvimento de seus estudos. Através de pesquisa foi possível fazer um levantamento dos artigos mais citados no Scopus, ou seja, os artigos mais impactantes dos 39 artigos estudados nessa dissertação.

Scopus é considerada uma das bases de resumos e citações de literatura científica mais importante da atualidade. No seu banco de dados estão mais de 50 milhões de registros de documentos científicos (ELSEVIER, 2016). 
Através do gráfico 14 observa-se que os artigos representados pelos números 16 e 8 são os que possuem a maior quantidade de citações dentro do banco de dados do Scopus. O artigo número 16 (Role of crystal structure in flotation separation of diaspore from kaolinite, pyropHyllite and illite) com setenta e uma citações dos autores Y. Hu , X Liu e Zhenghe Xu publicado no ano de 2003 é o artigo mais influente de todos os 39 artigos analisados. As setenta e uma citações do artigo 16 pelo Scopus são dividas nos seguintes períodos: duas citações (2004), quatro citações (2005), duas citações (2006), cinco citações (2007), nove citações (2008), seis citações (2009), seis citações (2010), nove citações (2011), doze citações (2012), seis citações (2013), sete citações (2014) e três citações (2015).

Pode-se explicar a relevância do artigo 16 na comunidade científica por ser um dos primeiros estudos sobre flotação de caulinita no acervo do Scopus. O artigo de número 16 estuda a molhabilidade e a eletrocinética dos minerais de caulinita, ilita, pirofilita e diásporo. Trabalha com testes de flotação utilizando coletores catiônicos e os resultados são considerados satisfatórios na separação de aluminossilicatos de diásporo através da flotação reversa.

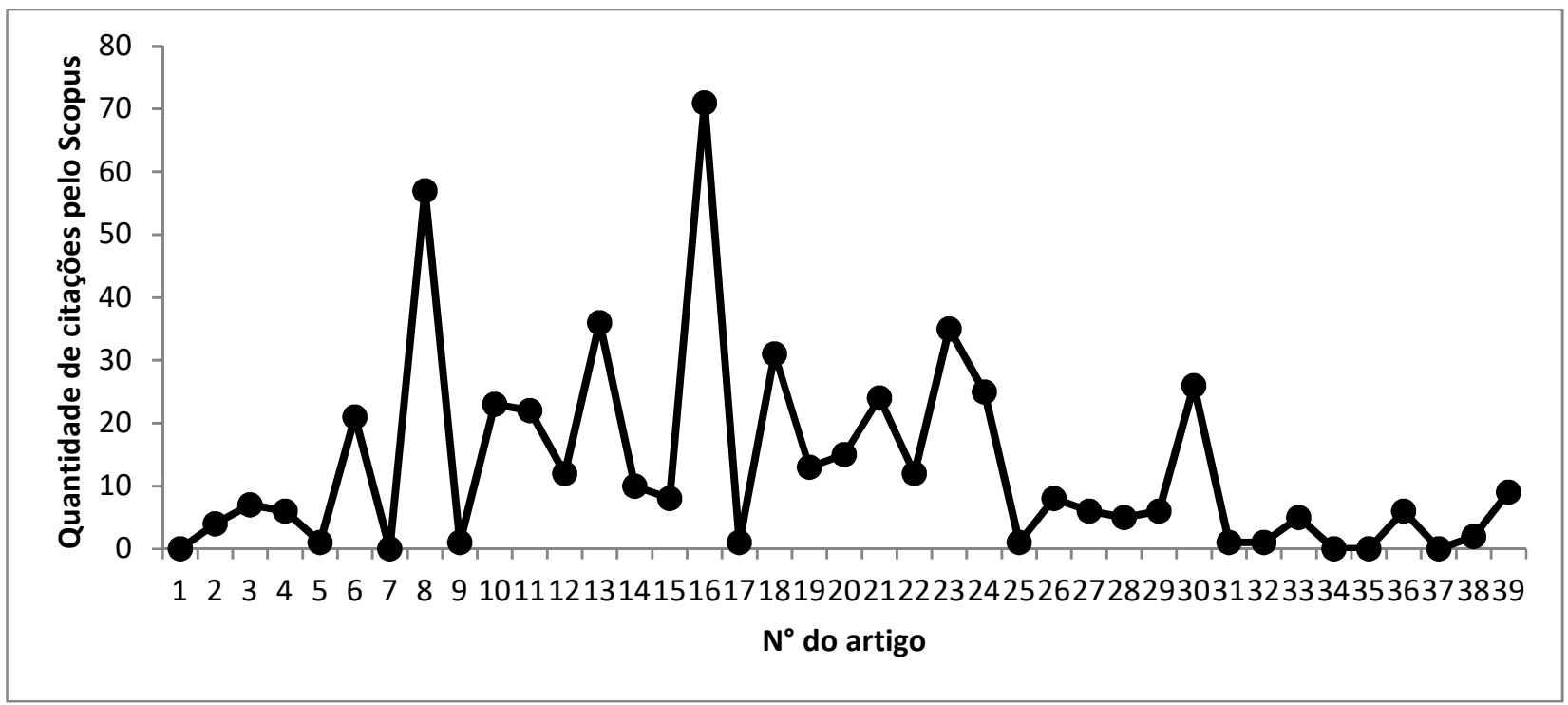

Gráfico 14: Artigos mais citados pelo Scopus (Elaboração própria) 
Já o artigo de número 8 (Chemical composition and surface property of kaolins) possui quinquenta e sete citações dentro do Scopus. Os autores do artigo número 8 são os mesmos do artigo 16: Y. Hu e X. Liu (exceto Zhenghe Xu que não está presente na pesquisa do artigo número 8). Assim como o artigo de número $16 \circ$ artigo de número 8 foi publicado no ano 2003. O artigo descreve o estudo sobre a cristalinidade do caulim (caulim duro e caulim mole) além da química de superfície da caulinita e sua influência na flotabilidade do mineral de caulinita.

Já no gráfico 15 é apresentada a linha do tempo das citações. Observa-se um crescimento significativo do ano 2003 até 2014, e uma diminuição de 33,3\% das citações do ano de 2014 para 2015. Pode-se justificar esse aumento de citações dos anos 2003-2004 para os anos de 2014-2015 devido ao interesse pelo mineral de caulinita para produção de matérias cerâmicos e pela crescente demanda de bauxita no mundo.

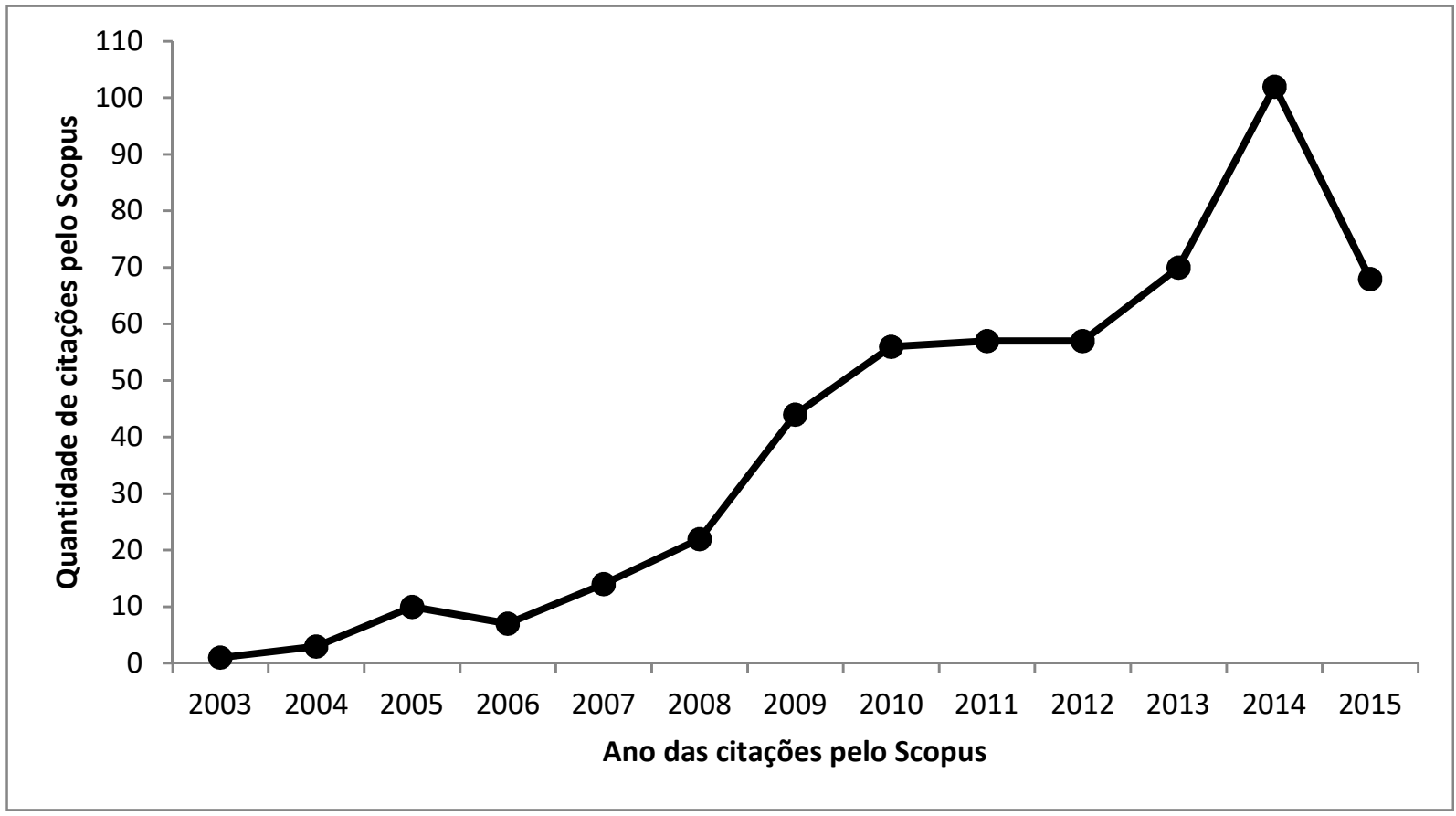

Gráfico 15 - Linha do tempo das citações pelo Scopus (Elaboração própria)

\subsection{Citações dos 39 artigos da análise bibliométrica}


Seguindo a mesma linha de raciocínio de que artigos mais frequentemente citados têm, provavelmente, maior influência do que aqueles menos citados, um novo levantamento de estudo de citações foi realizado. Nessa nova discussão foram utilizados apenas os artigos envolvidos nessa dissertação, ou seja, através de uma busca em todas as referências bibliográficas dos 39 artigos (anexo 1) foi possível verificar quais são os artigos sobre flotação de caulinita que mais influenciaram os novos artigos sobre o mesmo tema dentro do Science Direct.

Conforme a figura 32, observa-se que os artigos de número 16,18 e 23 foram os artigos que mais influenciaram novas pesquisas sobre o tema "flotação de caulinita". O artigo de número 16 (Role of crystal structure in flotation separation of diaspore from kaolinite, pyrophyllite and illite), novamente aparece como o mais mencionado em comparação aos outros. Com quinze citações, os artigos que citam o artigo de número 16 são de prevalência de autoria chinesa, exceto o artigo de número 37 que a pesquisa foi realizada nos Estados Unidos.

Os artigos de número 18 e 23 possuem quatorze citações cada. As citações do artigo 18 são todas de artigos desenvolvidos na China. Já as citações do artigo número 23 são: treze de citações de pesquisadores chineses e uma citação de pesquisadores americanos.

Artigos que não aparecem na figura 32, não foram citados nenhuma vez.

Obs: No anexo 1 da dissertação os artigos numerados são detalhados com as seguintes informações: título do artigo, ano, autores e revista da publicação. 


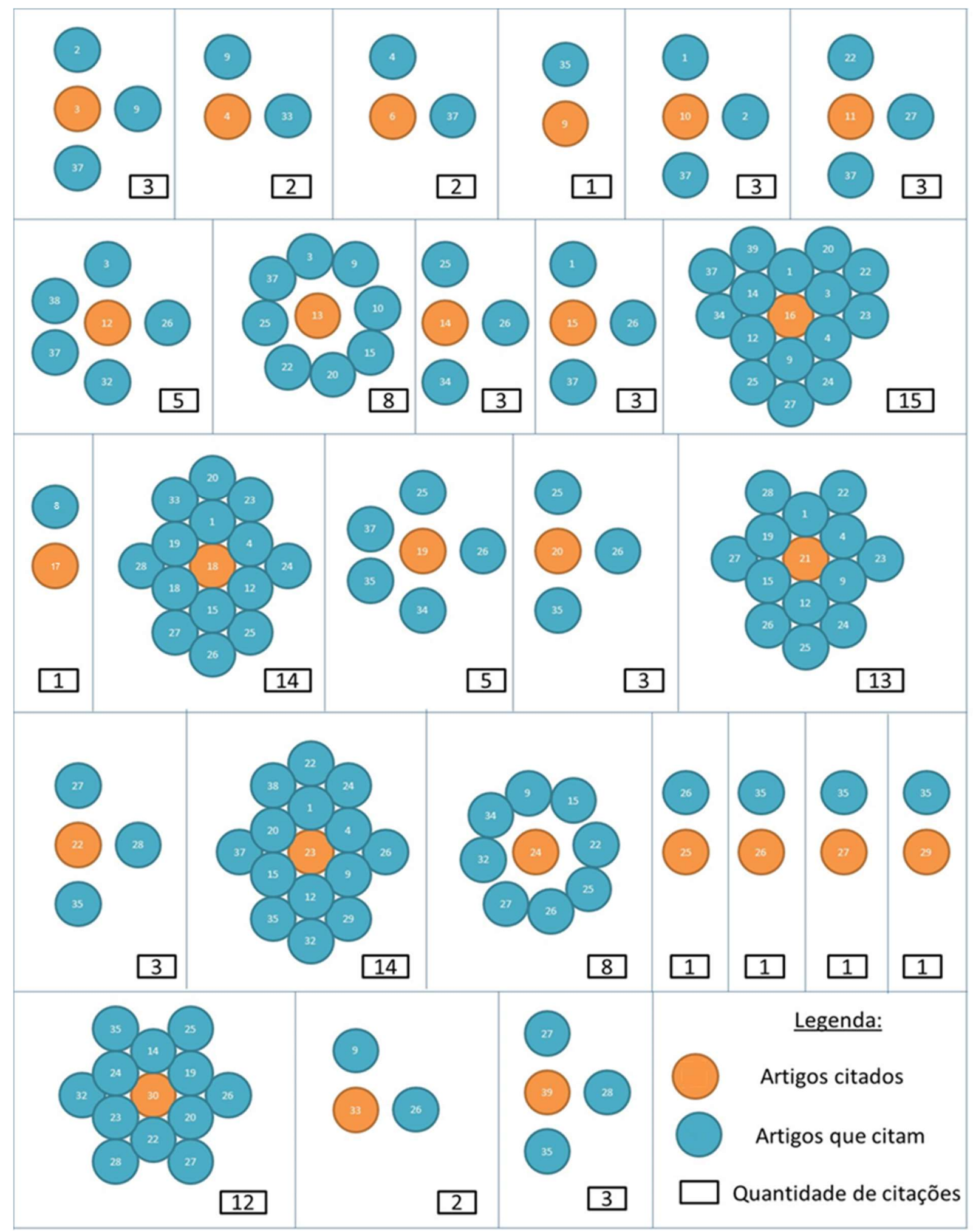

Figura 32: Artigos sobre flotação de caulinita que são mais citados por artigos do mesmo tema (Elaboração própria) 


\subsection{Reagentes utilizados nos ensaios de flotação dos artigos 39 artigos}

Conforme mencionado no capítulo 3 de Metodologia os reagentes (coletores, depressores e outros) utilizados na flotação do mineral de caulinita foram classificados por grupos químicos. Dessa forma verificou-se quais são os coletores mais aplicados nos estudos de flotação da caulinita.

O gráfico 16, a seguir, apresenta a relação de reagentes utilizados nos ensaios de flotação dos artigos da amostra. É possível observar a maior concentração de trabalhos com coletores de sais quaternários de amônio (22\%) seguido de coletores de ácidos carboxílicos com $19 \%$. Os ácidos carboxílicos apesar de serem representativos nessa tabela foram utilizados em grande quantidade em apenas três artigos e apresentou uma péssima flotabilidade para o mineral de caulinita.

Aminas terciárias representam $9 \%$ da amostra, amina primária e sal de amina primária juntos representam $12 \%$, éter-amina, monoamina e éter-diamina com $5 \%$ ao todo e amida $5 \%$. 


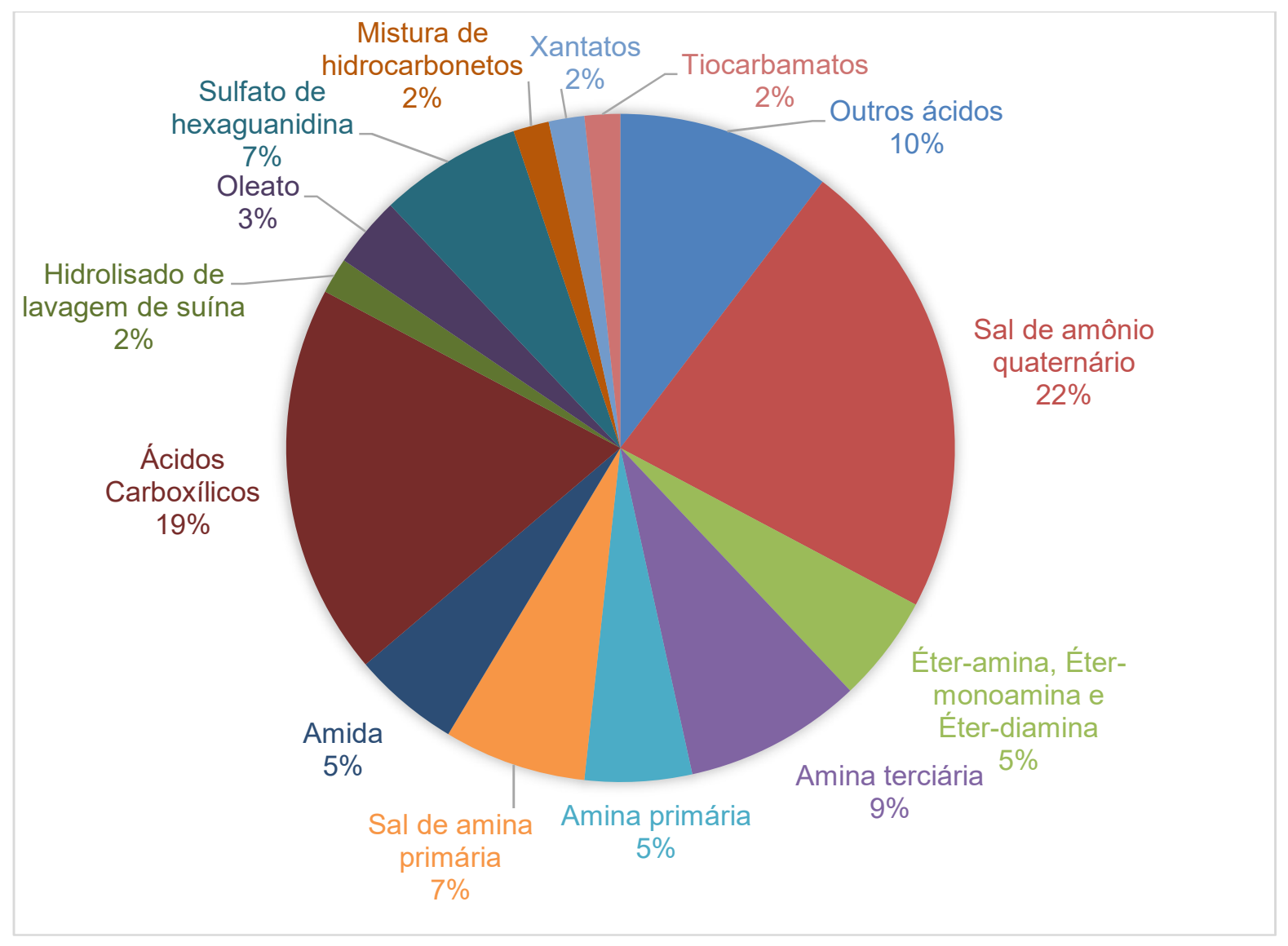

Gráfico 16: Reagentes utilizados nos ensaios de flotação dos 39 artigos

(Elaboração própria)

\subsection{Nome dos reagentes químicos utilizados nos 39 artigos analisados.}

A Tabela número de 6 apresenta os nomes e as abreviações dos reagentes químicos utilizadas nos 39 artigos. Na primeira coluna da tabela estão descritas as abreviações químicas dos reagentes utilizados nos 39 artigos, e na segunda coluna, o nome químico ou fórmula das abreviações. 
Tabela 6 - Nome químico ou comercio dos reagentes químicos utilizados nos 39 artigos por extenso e seus respectivas abreviações.

\begin{tabular}{|c|c|}
\hline Abreviação & Nome químico \\
\hline DTAC & Cloreto de dodeciltrimetil amônio \\
\hline CTAC & Cloreto de cetiltrimetil amônio \\
\hline Flotigam EDA & Eter amina \\
\hline DTAB & Brometo de dodeciltrimetil amônio \\
\hline AQ142 & Tomamine Q-14-2 PG \\
\hline DRN & $\mathrm{N}, \mathrm{N}$ - dodecil amina dissubstituída (com metill $\mathrm{CH} 3$ ) \\
\hline DEN & $\mathrm{N}, \mathrm{N}$-dodecil amina dissubstituída (com etil -C2H5) \\
\hline DPN & $\mathrm{N}, \mathrm{N}-$ dodecil amina dissubstituída (com propil -C3H7) \\
\hline DBN & $\mathrm{N}, \mathrm{N}$-dodecil amina dissubstituída (-C7H7) \\
\hline CTAB & Brometo de cetiltrimetil amônio \\
\hline Flotigam EDA 3 & Eter monoamina \\
\hline Flotigam 2835-2L & Eter diamina \\
\hline Dodecilamina & Dodecilamina \\
\hline DDA ou DC & Acetato de dodecilamina \\
\hline PAM ou CPAM & Poliacrilamidas \\
\hline BDDA ou $12-4-12$ & Brometo de dimetildodecil amónio dissubstituído \\
\hline PN & N,N- dipropil dodecil amina \\
\hline DDTA & Sal de amônio (radical alquila) \\
\hline CPC / CPCL & Cloreto de cetilpiridínio \\
\hline DDAC & Cloreto de dodecilamina \\
\hline DDGS & Sulfato de dodecil guanidina \\
\hline SDBS & Dodecilbenzenosulfonato de sódio \\
\hline AMD & Hidroxialquilo dietanolamina \\
\hline A55 & Alquil benzeno sulfonato de sódio \\
\hline ADPA & $\mathrm{N}$-(3-aminopropil)-dodecamida \\
\hline Oleato & Oleato de sódio \\
\hline (SAG6) & Sulfato de hexilguanidina \\
\hline (SAG8) & Sulfato de octilguanidina \\
\hline (SAG10) & Sulfato de decilguanidina \\
\hline (SAG12) & Sulfato dodecilguanidina \\
\hline AENA & $\mathrm{N}$-(2-aminoetill) -1 naftaleno acetamida \\
\hline OCB & Ácido orto-carboxilo tetracloro benzohidroxámico \\
\hline $\mathrm{OHB}$ & Ácido orto-carboxil hexahidro benzohidroxámico \\
\hline OTB & Ácido orto-carboxil tetrahidro benzohidroxámico \\
\hline
\end{tabular}




\begin{tabular}{|c|c|}
\hline EDDA & Brometo de dodecil dimetil amônio \\
\hline BBAB & $\begin{array}{l}\text { Gemini surfactante de trisiloxano butano-1,4-bis (dimetil- (3- (3-aminopropil } \\
\text { trisiloxano-3-il) -propil-etil) -amónio) }\end{array}$ \\
\hline BHUA & Ácido 3,3-bis (hidroxi carbomil) dodecanoico \\
\hline BHTA & Ácido 3,3-bis (hidroxi carbomil) tridecanoico \\
\hline BHPA & Ácido 3,3-bis (hidroxi carbomil) pentadecanoico \\
\hline $\mathrm{ABHC}$ & Ácido 4-alquil-4,4- bis (hidroxi carbomil) \\
\hline HCDA & Ácido 4-alquil-4,4- bis (hidroxi carbomil) dodecanoico \\
\hline HCTA & Ácido 4-alquil-4,4- bis (hidroxi carbomil) tetradecanoico \\
\hline $\mathrm{HCHA}$ & Ácido 4-alquil-4,4- bis (hidroxi carbomil) hexadecanoico \\
\hline $\mathrm{HHO}$ & Hidrolisado de lavagem suína \\
\hline ATNO & $\mathrm{AICl}_{3} / \mathrm{Na}_{2} \mathrm{SiO}_{3}$ \\
\hline TTAC & Cloreto de tetradecil trimetil amônio \\
\hline $103 C$ & Dodecil trimetil amônio \\
\hline NHOD & N-(6-(hidroxi amino)-6-oxo-hexil) decanamida \\
\hline $\mathrm{DC}$ & Hidrocloreto de dodecilamina \\
\hline $\mathrm{D} 8$ & $(\mathrm{C} 8 \mathrm{H} 17) 2(\mathrm{CH} 3) 2 \mathrm{NCl}$ \\
\hline CMCA & Ácido 2-carboxil-6-metil ciclo hidroxâmico \\
\hline CDHA & Ácido 2-carboximetill-decileno-4-il hidroxâmico \\
\hline CTHA & Ácido 2-carboxImetll-tetradecem-4-il hidroxâmico \\
\hline WMS & Amido de milho \\
\hline SIPX & Isopropil xantato de sódio \\
\hline PEO & Polímero \\
\hline DAC 5 e APAM & Poliacrilamidas \\
\hline 1031 & $\mathrm{C}_{10} \mathrm{H}_{21}\left(\mathrm{CH}_{3}\right)_{3} \mathrm{NCl}$ \\
\hline 1231 & $\mathrm{C}_{12} \mathrm{H}_{25}\left(\mathrm{CH}_{3}\right)_{3} \mathrm{NCl}$ \\
\hline 1222 & $\mathrm{C}_{12} \mathrm{H}_{25} \mathrm{C}_{2} \mathrm{H}_{5}\left(\mathrm{CH}_{3}\right)_{2} \mathrm{NCl}$ \\
\hline $\mathrm{F} 4$ & $\left(\mathrm{C}_{4} \mathrm{H}_{9}\right)_{4} \mathrm{NCl}$ \\
\hline Diesel & Hidrocarboneto \\
\hline MIBC & Metil isobutil carbinol \\
\hline
\end{tabular}

\subsection{Análise do pH de flotação}

Os 39 artigos da análise bibliométrica do presente trabalho mostraram que o pH de flotação de caulinita não é o mesmo para todos os estudos.

O objetivo das tabelas 7 e 8 é mostrar em qual $\mathrm{pH}$ o coletor usado nos estudos dos artigos possui uma recuperação na flotação superior de $60 \%$ para o mineral de 
caulinita. Na segunda coluna das tabelas 7 e 8 , são apresentados os coletores de caulinita que obtiveram uma recuperação maior de 60\% em meio ácido $\mathrm{pH}$ menos de 7). Já na terceira coluna, estão apresentados os coletores de caulinita com recuperação superior a $60 \%$ em meio neutro $(\mathrm{pH} 6,5$ até 7,5), na quarta os coletores de caulinita que mostraram recuperações superiores de $60 \%$ em meio alcalino (superior de 7,5). Já na quinta coluna os coletores que não atingiriam recuperações de $60 \%$.

Detalhes como: valores aproximados de recuperação e pH de flotação são encontrados no item 3.15 (Recuperações dos coletores utilizados nos ensaios de flotação nos 39 artigos).

No anexo 1 da dissertação os artigos numerados são detalhados (título do artigo, ano, autores e revista da publicação). 
Tabela 7 - Nome dos reagentes químicos utilizados nos artigos 1 até 20 por pH de flotação

\begin{tabular}{|c|c|c|c|c|}
\hline \multirow{2}{*}{$\begin{array}{c}\text { pH. } \\
\text { ARTIGO }\end{array}$} & \multirow{2}{*}{$\begin{array}{l}\text { Ácido (1 -7) } \\
\text { MEIO ÁCIDO }\end{array}$} & \multirow{2}{*}{$\begin{array}{c}\text { Ne utro }(6,5 \text { - 7,5) } \\
\text { MEO ÁCIDO E BÁsICO } \\
\text { (NEUTRO) }\end{array}$} & \multirow{2}{*}{$\begin{array}{c}\text { Bás ico (maior que } 7,5 \text { ) } \\
\text { MEO BÁsıco }\end{array}$} & \multirow{2}{*}{$\begin{array}{c}\text { Recuperação em } \\
\text { massa menor } \\
\text { que } 60 \%\end{array}$} \\
\hline & & & & \\
\hline 1 & $\begin{array}{c}97 \% \text { (DTAC) fração }-0,1 \\
+0,045,98 \% \text { (CTAC) fração - } \\
0,1+0,075 \mathrm{~mm}\end{array}$ & (CTAC) fração $-0,1+0,045 \mathrm{~mm}$ & $\begin{array}{c}86 \% \text { (CTAC) fração }-0,1- \\
0,075 \mathrm{~mm}\end{array}$ & - \\
\hline 2 & $\begin{array}{c}\text { (DTAB) } 94 \%,(\text { AQ142) } 70 \% \\
\text { Flotigam EDA } 65 \%\end{array}$ & $\begin{array}{c}\text { (DTAB) } 98 \%,(\text { AQ142) } 80 \%, \\
\text { Flotigam EDA } 92 \%\end{array}$ & $\begin{array}{l}\text { (DTAB) 90\%, (AQ142) } \\
99 \%, \text { Flotigam EDA } 98 \%\end{array}$ & - \\
\hline 3 & (DTAC) 78\%', (CTAC) 80\% & $\begin{array}{c}\text { (flotou } 70 \%) \text { (DTAC) , (CTAC) } \\
72 \%\end{array}$ & (CTAC) 67\%, DTAC 65\% & - \\
\hline 4 & $\begin{array}{c}\text { DRN (88\%), DEN (94\%), DPN } \\
(92 \%), \text { DBN (81\%) }\end{array}$ & $\begin{array}{c}\mathrm{DRN}(70 \%), \mathrm{DEN}(88 \%), \mathrm{DPN} \\
(77 \%)\end{array}$ & $\begin{array}{c}\text { DRN (64\%), DEN ( } 87 \%) \\
\text { DPN }(75 \%)\end{array}$ & - \\
\hline 5 & $\begin{array}{c}\text { (DDA) com WMS } 82 \% \text {, sem } \\
\text { WDS } 80 \%\end{array}$ & $\begin{array}{c}\text { (DDA) com WMS 78\%, sem WDS } \\
73 \% \\
\end{array}$ & $\begin{array}{l}\text { (DDA) com WMS } 77 \% \\
\text { sem WDS } 75 \%\end{array}$ & - \\
\hline 6 & (CTAB) $79 \%$ & (CTAB) $70 \%$ & - & - \\
\hline 7 & - & - & - & SIPX \\
\hline 8 & $\begin{array}{l}\text { (CTAB SOFT - 95\%), (CTAB } \\
\text { HARD - 75\%), (DAA SOFT - } \\
\text { 97\%), (DAA HARD - 76\%) }\end{array}$ & $\begin{array}{l}\text { (CTAB SOFT- } 81 \%) \text {, (CTAB } \\
\text { HARD- 75\%), (DAA SOFT - } \\
80 \%),(\text { DAA HARD - } 65 \% \text { ) }\end{array}$ & $\begin{array}{c}\text { (CTAB SOFT - } 71 \%), \\
\text { (CTAB HARD- } 60 \%), \\
\text { (DAA SOFT - 84\%), (DAA } \\
\text { HARD }>60 \%)\end{array}$ & - \\
\hline 9 & - & - & - & Oleato de sódio \\
\hline 10 & 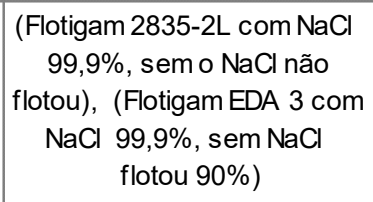 & $\begin{array}{c}\text { (Flotigam } 2835-2 \mathrm{~L} \text { com } \mathrm{NaCl} \\
99,9 \% \text {, sem o } \mathrm{NaCl} \text { não flotou), } \\
\text { (Flotigam EDA } 3 \mathrm{com} \mathrm{NaCl} \text { maior } \\
\text { que } 90,0 \%, \text { sem } \mathrm{NaCl} \text { flotou } \\
73 \%)\end{array}$ & $\begin{array}{c}\text { (Flotigam 2835-2L com } \\
\mathrm{NaCl} 99,9 \% \text {, sem o } \mathrm{NaCl} \\
\text { não flotou), (Flotigam EDA } \\
3 \mathrm{com} \mathrm{NaCl} 90,0 \%, \text { sem } \\
\mathrm{NaCl} \text { flotou } 70 \%)\end{array}$ & - \\
\hline 11 & $\begin{array}{l}\text { (DDA) acetato com APAM } \\
94 \% \text { sem APAM } 73 \%\end{array}$ & (DDA) acetato com APAM 79\% & $\begin{array}{c}\text { (DDA) acetato com APAM } \\
79 \%\end{array}$ & - \\
\hline 12 & $\begin{array}{c}\text { DRN (88\%), DEN (94\%), DPN } \\
(92 \%), \text { DBN }(81 \%)\end{array}$ & $\begin{array}{c}\text { DRN }(70 \%), \text { DEN (88\%), DPN } \\
(77 \%)\end{array}$ & $\begin{array}{c}\text { DRN }(64 \%), \text { DEN }(87 \%) \\
\text { DPN }(75 \%)\end{array}$ & - \\
\hline 13 & & Sem resultado de recuperaç & ão em massa. & \\
\hline 14 & $(12-4-12) 98 \%$ & $(12-4-12) 98 \%$ & $(12-4-12) 94 \%$ & - \\
\hline 15 & PN (91\%) & PN (77 \%) & $\mathrm{PN}(60 \%)$ & - \\
\hline 16 & (DDTA) 78\%, (DDA) 77\% & (DDTA) $70 \%,(\mathrm{DDA}) 65 \%$ & (DDTA) $65 \%$ & Oleato de sódio \\
\hline 17 & $\begin{array}{c}\text { CPCL }(99 \%), \text { AMD }(99 \%), \\
\text { A55 97\% }\end{array}$ & $\begin{array}{c}\text { CPCL }(99 \%), \text { AMD (94\%), A55 } \\
(75 \%)\end{array}$ & - & - \\
\hline 18 & ADPA $(80 \%)$ & ADPA $(76 \%)$ & ADPA $(74 \%)$ & - \\
\hline 19 & (DTAB) $99 \%,(12-4-12) 98 \%$ & (DTAB) $88 \%,(12-4-12) 98 \%$ & $\begin{array}{c}\text { (DTAB) } 78 \%(12-4-12) \\
98 \%\end{array}$ & - \\
\hline 20 & $\begin{array}{c}\text { SAG 8, SAG 10, SAG } 12> \\
95 \%\end{array}$ & SAG 8, SAG 10, SAG $12>85 \%$ & $\begin{array}{c}\text { SAG 8, SAG 10, SAG } 12> \\
80 \%\end{array}$ & SAG 6 \\
\hline
\end{tabular}


Tabela 8 - Nome dos reagentes químicos utilizados nos artigos 21 até 39 por pH de flotação.

\begin{tabular}{|c|c|c|c|c|}
\hline ARTIGO & Ácido (1 -7) & $\begin{array}{l}\text { Neutro }(6,5 \text { - 7,5) } \\
\text { MEO ÁCIDO E BÁSICO } \\
\text { (NEUTRO) }\end{array}$ & Básico (maior que 7,5) & $\begin{array}{c}\text { Recuperação em } \\
\text { massa menor } \\
\text { que } 60 \%\end{array}$ \\
\hline 21 & - & - & - & AENA \\
\hline 22 & - & - & - & OCB, OHB, OTB \\
\hline 23 & $\begin{array}{c}\text { (DTAC) 98\%, (DDGS) 97\%, } \\
\text { (DDAC) 83\% }\end{array}$ & $\begin{array}{c}\text { (DTAC) } 90 \%,(\mathrm{DDGS}) 92 \%, \\
\text { (DDAC) } 65 \%\end{array}$ & $\begin{array}{c}\text { (DTAC) } 80 \%, \quad(\text { DDGS) } \\
75 \%\end{array}$ & - \\
\hline 24 & (BDDA) $97 \%$, (DTAB) $98 \%$ & (BDDA) $97 \%$, (DTAB) $90 \%$ & (BDDA) $95 \%$ (DTAB) $70 \%$ & - \\
\hline 25 & (BDDA) $98 \%$ (EDDA) 87\% & (BDDA) $98 \%,($ EDDA) $80 \%$ & $\begin{array}{c}\text { (BDDA) } 96 \%,(\text { EDDA }) \\
79 \%\end{array}$ & - \\
\hline 26 & $\begin{array}{c}\text { (BBAB) } 98 \%,(\mathrm{DTAB}) 90 \% \\
\text { (DDA) } 80 \%\end{array}$ & $\begin{array}{c}\text { (BBAB) } 97 \%, \text { (DTAB) } 78 \%, \\
\text { (DDA) } 60 \%\end{array}$ & (BBAB) $96 \%$, (DTAB) $60 \%$ & - \\
\hline 27 & - & - & - & BHUA, BHTA, BHPA \\
\hline 28 & - & - & - & $\begin{array}{c}\mathrm{HCDA}, \mathrm{HCTA} \text {, and } \\
\text { HCHA }\end{array}$ \\
\hline 29 & - & - & - & $\mathrm{HHO}$ \\
\hline 30 & $\begin{array}{c}(\mathrm{DDA} 95 \%)-(\mathrm{DDA} \text { com DAC- } \\
5 \text { CEPAM, 93\%) }\end{array}$ & $\begin{array}{c}(\mathrm{DDA}-85 \%)-(\mathrm{DDA} \text { com DAC-5 } \\
\text { CEPAM, 81\%) }\end{array}$ & $\begin{array}{l}\text { (DDA - 79\%) - (DDA com } \\
\text { DAC-5 CEPAM, 84\%) }\end{array}$ & - \\
\hline 31 & $\begin{array}{c}\text { (DDA } 81 \%)-(D D A \text { com } \\
\text { ATNO, 39\%) }\end{array}$ & $\begin{array}{c}(\mathrm{DDA} 87 \%)-(\mathrm{DDA} \text { com ATNO, } \\
82 \%)\end{array}$ & (DDA com ATNO, 61\%) & - \\
\hline 32 & $\begin{array}{c}\text { DRN (88\%), DEN (94\%), DPN } \\
(92 \%)\end{array}$ & $\begin{array}{c}\text { DRN }(70 \%), \text { DEN (88\%), DPN } \\
(77 \%)\end{array}$ & $\begin{array}{c}\text { DRN }(64 \%), \text { DEN }(87 \%) \\
\text { DPN }(75 \%)\end{array}$ & - \\
\hline 33 & $\begin{array}{c}98 \% \text { (DTAC) } 0,045-0,1 \mathrm{~mm}, \\
96 \% \text { (CTAC) fração 0,045 - } \\
0,1 \mathrm{~mm}, 89 \% \text { (103C) fração } \\
0-0,1 \mathrm{~mm}, 99 \% \text { (TTAC) } \\
\text { fração }-0,045-0,1 \mathrm{~mm}, 68 \% \\
\text { (103C) } 0-0.045 \mathrm{~mm}\end{array}$ & $\begin{array}{c}98 \% \text { (CTAC) } 0.075-0.1 \mathrm{~mm}, 76 \% \\
\text { (CTAC) 0.045-0.075 mm, 90\% } \\
\text { (TTAC) fração 0.075-0.1mm, } \\
76 \% \text { (TTAC) fração 0.045- } \\
0.075 \mathrm{~mm}, 68 \% \text { (103C) 0-0.045 } \\
\mathrm{mm}\end{array}$ & $\begin{array}{c}\text { (CTAC) } 86 \%,(\text { TTAC) } 91 \% \\
0,075-0,1 \mathrm{~mm}, 61 \% \\
(103 \mathrm{C}) 0-0.045 \mathrm{~mm}\end{array}$ & - \\
\hline 34 & (12-4-12) 98\%, & $(12-4-12) 98 \%$ & (12-4-12) 97\%, & - \\
\hline 35 & - & - & - & $\mathrm{NHOD}$ \\
\hline 36 & - & - & - & $\begin{array}{c}\text { Diesel e MBBC com } \\
\text { PEO }\end{array}$ \\
\hline 37 & DC $67 \%$ & - & - & - \\
\hline 38 & $\begin{array}{c}1031(70 \%), 1231 \\
(70 \%), 1222(60 \%), D 8 \\
(85 \%), \text { F4(56\%) }\end{array}$ & $1031(70 \%)$, D8 (70\%), F4 (73\%) & D8 (65\%), F4 (65\%) & $\begin{array}{l}\text { Reagentes que não } \\
\text { foram citados }\end{array}$ \\
\hline 39 & - & - & - & CDHA, CTHA, CMCC \\
\hline
\end{tabular}


Como observada na revisão bibliográfica o melhor desempenho na flotação de caulinita ocorre em meio ácido, embora seja possível encontrar flotabilidade de caulinita em meios alcalinos também. Como os estudos, em grande parte, utilizaram mais de um coletor para a caulinita, não foi possível fazer um gráfico citando o melhor $\mathrm{pH}$ de flotação de caulinita por artigo. Essa impossibilidade é devido aos coletores apresentarem, na maioria dos casos, suas melhores recuperações em pH ácido mas apresentarem recuperações maiores de $60 \%$ em meios neutros a alcalinos.

Um exemplo é o coletor DRN. Em pH ácido a sua maior recuperação de caulinita atinge a faixa de $88 \%$, já em meio neutro a sua maior recuperação é de $70 \%$ e em meio básico (próximo do pH 7,5) 64\%. Além desse coletor pode-se citar também do PN, onde, em meio ácido, foi observada uma recuperação de $91 \%$ do mineral de caulinita. $\mathrm{Na}$ faixa de $\mathrm{pH}$ alcalino, a sua maior recuperação é de aproximadamente $60 \%$. Outro exemplo é coletor DDA, onde recuperações maiores de $60 \%$ só foram conseguidas em pH ácido e neutro.

O coletor Flotigam EDA merece uma atenção especial. Diferente da maioria dos coletores estudados nos 39 artigos, O EDA concentra suas melhores recuperações de caulinita nas faixas neutras e alcalinas (92\% e 98\%). Na faixa ácida sua maior recuperação é de $65 \%$. Além dos coletores que apresentam flotabilidade em um ou maios meios, existem os coletores que não atingiram $60 \%$ de recuperação para caulinita, exemplo: SIPX, Oleato e NHOD.

No gráfico 17 são apresentados os resultados de melhor pH de flotação referente a todos os coletores citados. Nesse gráfico é considerado apenas o melhor $\mathrm{pH}$ onde ocorreu, pontualmente, a maior recuperação dos coletores de todos os valores apresentados nos artigos (recuperação maior que 60\%). É importante reforçar que muitos coletores exibiram ótimos resultados também em outras faixas de $\mathrm{pH}$. 


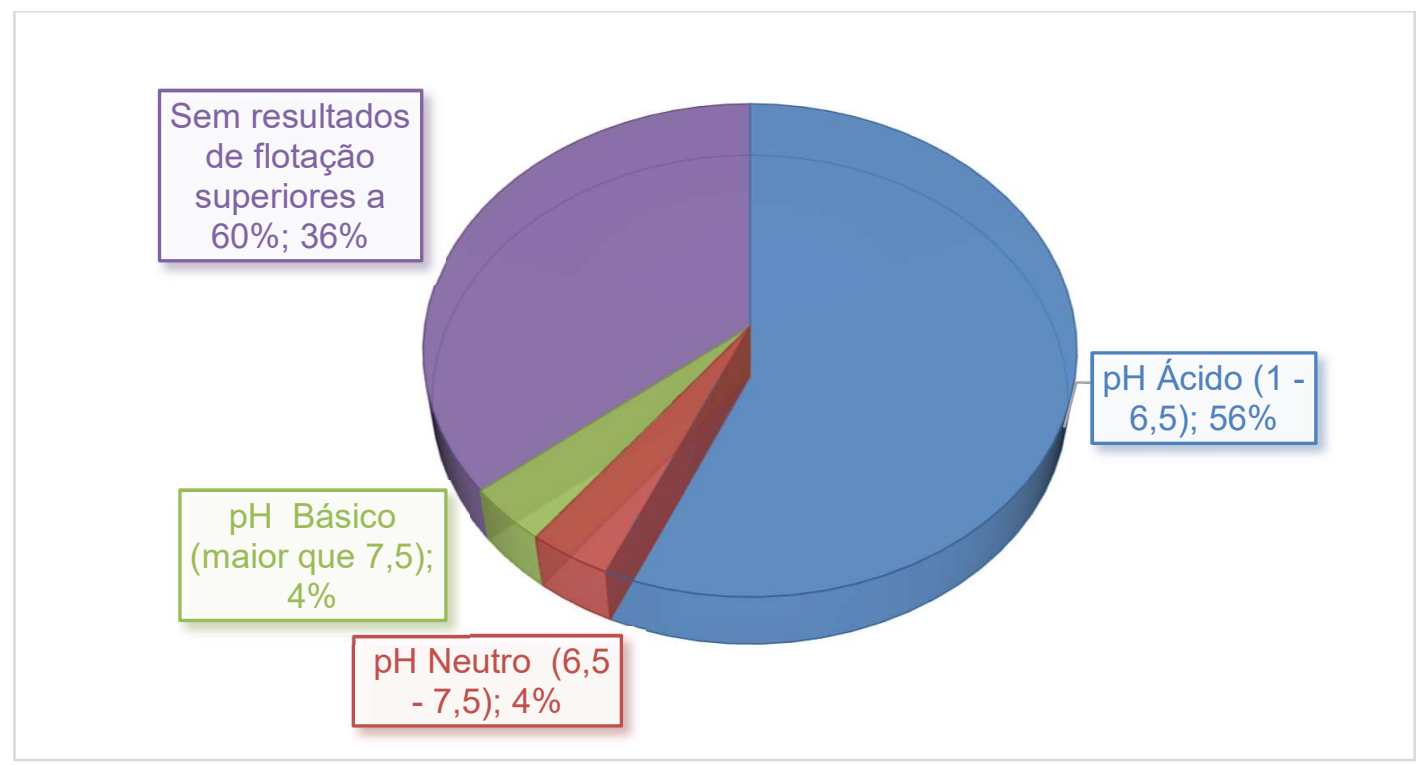

Gráfico 17 - pH que concentra o maior valor de recuperação de caulinita dos coletores (Elaboração própria)

A maior recuperação de caulinita em meio ácido é predominante entre os coletores (60\% dos coletores). A melhor recuperação em meio básico verificou-se somente para $4 \%$. Coletores que apresentaram a maior recuperação em meio neutro foram $4 \%$. Os que apresentaram baixa recuperação na flotação para caulinita, menor que $60 \%$, foram $36 \%$ de todos os coletores.

Como descrito na revisão bibliográfica, embora exista um consenso geral de que o modelo eletrostático seja o principal mecanismo de adsorção de aminas graxas em silicatos, na flotação de caulinita (principalmente na China), o mineral apresenta sua melhor condição de flotação em meio ácido. Os autores chineses utilizaram mais de 40 reagentes diferentes e todos apresentaram sua melhor flotabilidade para caulinita em meio ácido. No item 3.15 (Recuperações dos coletores utilizados nos ensaios de flotação nos 39 artigos) pode-se observar com mais detalhe essa última afirmação.

A grande questão que os chineses se propuseram a responder sobre o $\mathrm{pH}$ de flotação da caulinita, é a seguinte (exemplo do estudo do artigo 6): se em estudos de espectroscopia no infravermelho mostram que o pH onde ocorre a maior adsorção do 
coletor (nesse caso o CTAB) é em meio básico (indicando o mecanismo de atração eletrostático), o por que a maior flotabilidade ocorre em meio ácido? Conforme os autores do artigo 6 a maior flotabilidade em meio ácido deve-se ao fenômeno de agregação. Em meio ácido a borda possui carga positiva e o plano basal carga negativa. Como as partículas de caulinita possuem duas cargas distintas, as partículas se atraem e ocorre uma interação entre si formando uma estrutura agregada. Já no pH básico, como não há atração entre as partículas (todos os planos estão negativos) não ocorre o fenômeno de agregação.

\subsection{Recuperações dos coletores utilizados nos ensaios de flotação nos 39 artigos}

Nesse item são descritos os principais resultados de recuperação da flotação de caulinita e seus respectivos coletores. Recuperações dos minerais que não sejam o mineral de caulinita não foram mencionadas, exceto quando o artigo também emprega no estudo um depressor. Os gráficos 18, 19 e 20 apresentam as recuperações dos testes de flotação realizados pelos artigos estudados nessa pesquisa.

Observações importantes na construção dos gráficos:

- Obs. 1: Os resultados de recuperação de caulinita na flotação dos artigos de número 17 (Coletores CPCL, SDBS, AMD e A55) e de número 7 (Coletor SIPX) não constam no gráfico devido à quantidade de variáveis aplicadas no estudo pelos autores. Os resultados dos coletores $\mathrm{CPCL}$, AMD e A55 estão descritos no item 1.9 (Comportamento da caulinita na flotação).

- Obs. 2: Os resultados das recuperações dos 20 coletores utilizados no artigo de número 39 não estão na figura 34. Apenas o coletor D8 que apresentou a melhor flotabilidade está no gráfico 18.

- Obs. 3: O artigo de número 21 não apresentou dados de recuperação na flotação para o coletor AENA e não foi inserido dos gráficos 18 a 20. 
- Obs. 4: Os resultados das recuperações de caulinita na flotação para os coletores OCB, OHB, OTB, BHUA, BHTA, BHPA, HCDA, HCTA, HCHA, CMCA, CDHA e CTHA (artigos de número 22, 27, 28 e 39) não estão presentes nos gráficos 18,19 e 20 , pois a recuperação máxima foi de $35 \%$.

- Obs. 5: Os trabalhos que apresentam os resultados de recuperações nos testes de flotação por faixa granulométrica (DTAC, CTAC, 103C, TTAC e Oleato) não estão inseridos nos gráficos. Os resultados desses coletores estão individualmente escritos nos itens: 3.15.1, 13.15.2, 3.15.10, 3.15.11 e 3.15.26.

- Obs 6: Os resultados de flotação do artigo de número 7 não estão apresentados nessa dissertação, o estudo "The entrainment of kaolinite particles in copper and gold flotation using fresh water and sea water" não trabalha com flotação direta de caulinita. A medologia do estudo se aplica em estudar a flotação do ouro e do cobre na presença de caulinita, em água doce ou água salgada.

- Obs 7: Os valores dos gráficos foram retirados a partir dos gráficos apresentados nos artigos, portanto, foram estimados.

- Obs 8: Os resultados do artigo de número 36 não estão apresentados nesse capítulo em virtude da metodologia empregada no artigo. $\mathrm{O}$ artigo realiza testes em água salgada e água doce utilizando como coletor o Diesel, MIBC como espumante e PEO um polímero aplicado em quatro diferentes dosagens. $O$ estudo é direcionado para verificar o "arrastamento" do mineral de ganga (caulinita) na flotação. Os resultados de recuperação em massa da caulinita e de recuperação de água não atingiram $35 \%$ para o mineral. 


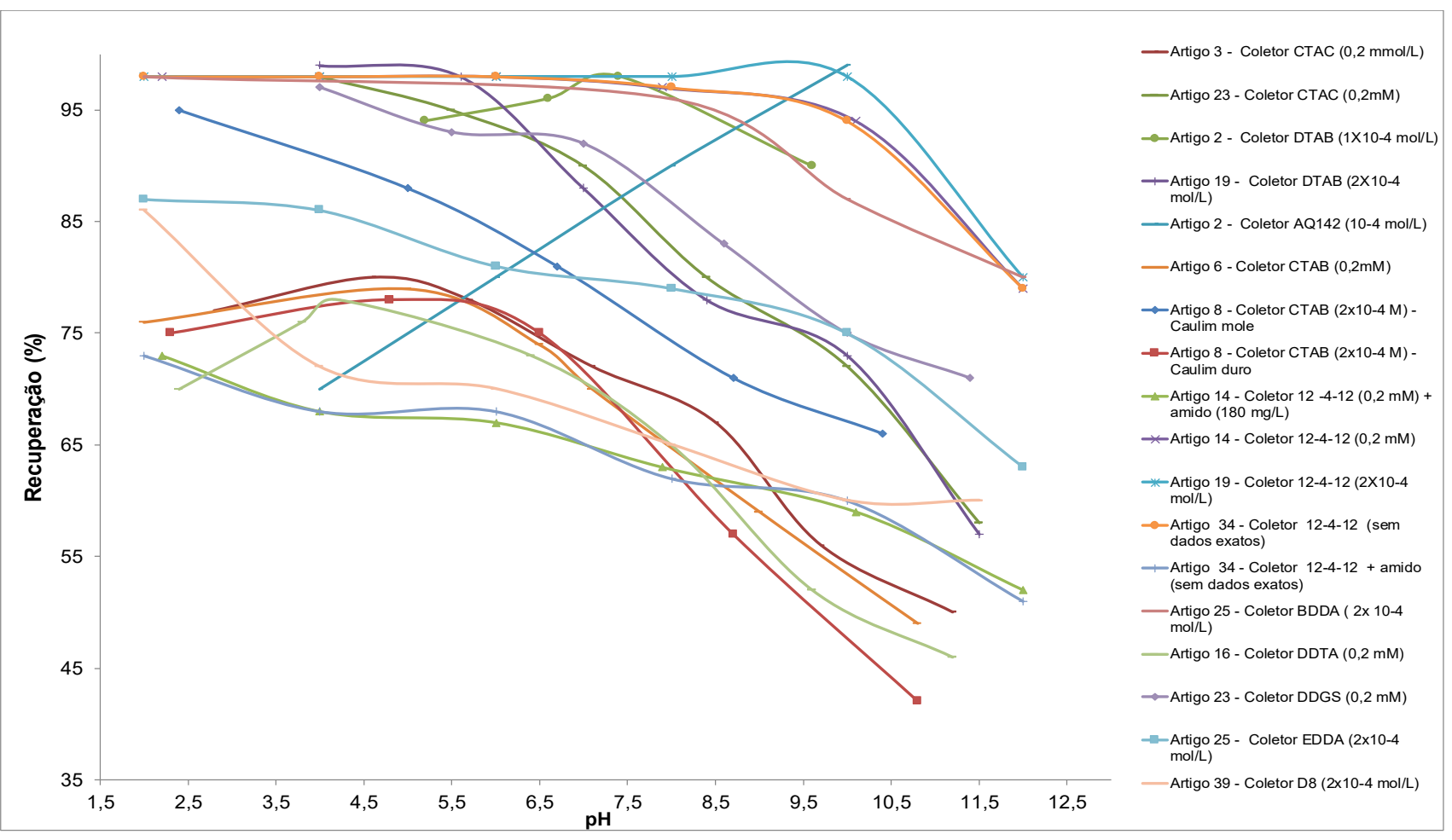

Gráfico 18 - Gráfico A dos coletores utilizados nos testes de flotação nos artigos da amostra (Elaboração própria) 


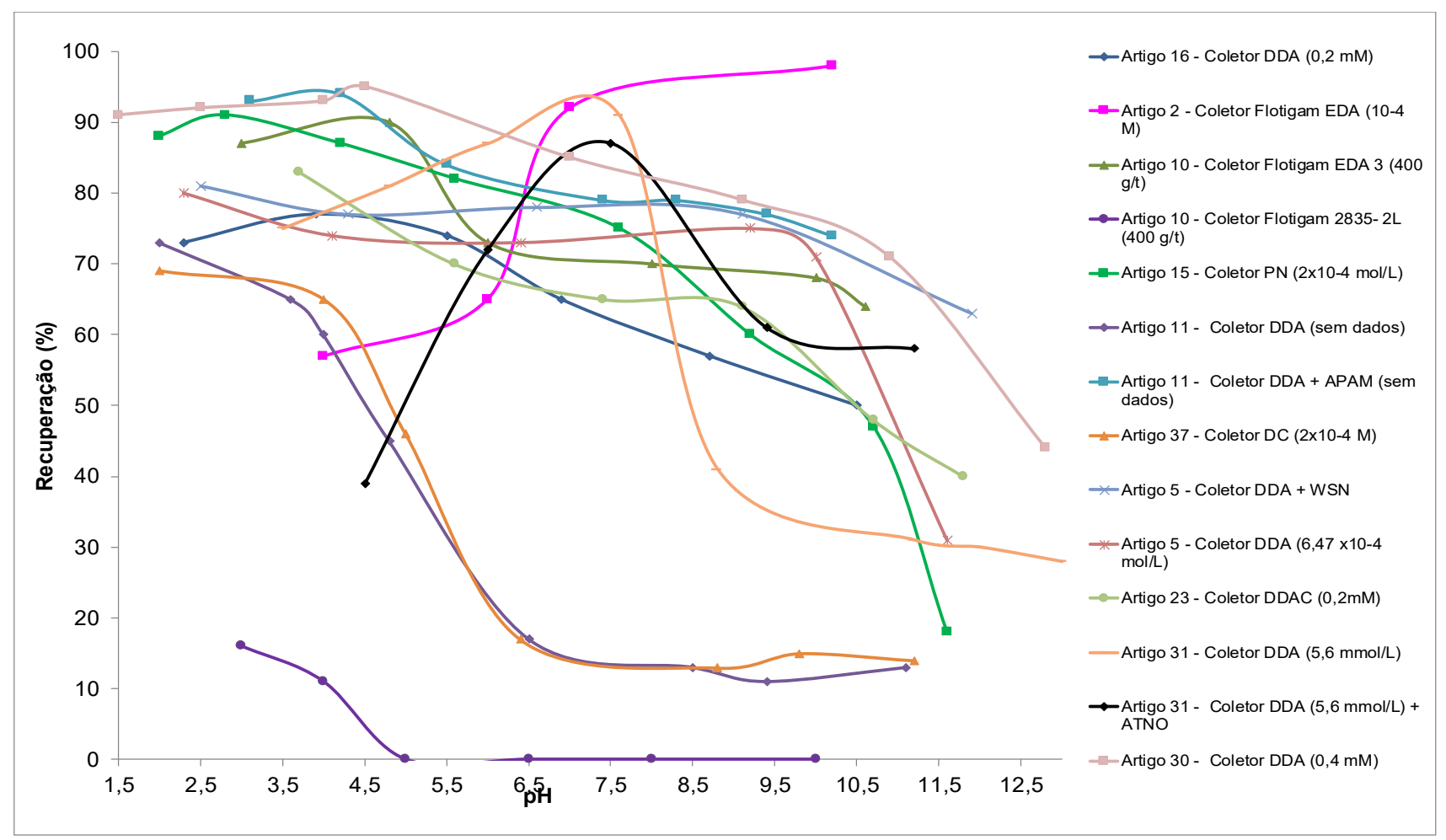

\section{Gráfico 19 - Gráfico B dos coletores utilizados nos testes de flotação nos artigos da amostra (Elaboração própria)}

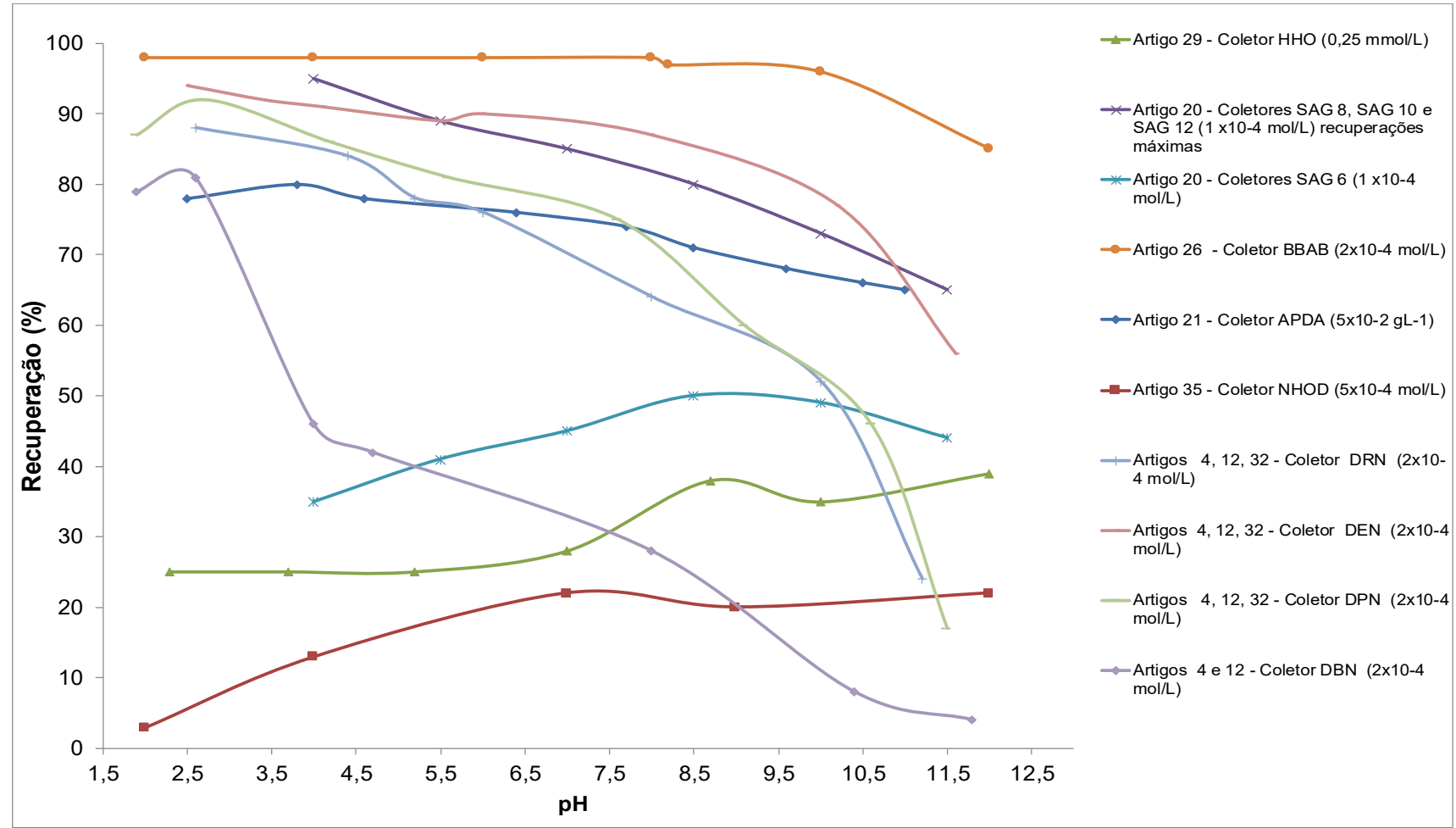


Gráfico 20 - Gráfico $C$ dos coletores utilizados nos testes de flotação nos artigos da amostra (Elaboração própria)

Através dos gráficos 18,19,20 é possível observar que os melhores resultados de recuperação para o mineral de caulinita ocorreram em meio ácido. Poucos coletores apresentaram seus melhores resultados em meio mais alcalino. Os coletores que apresentaram os seus melhores resultados em $\mathrm{pH}$ mais elevado foram: AQ142 (artigo 2) e Flotigam EDA (artigo 2).

Como os resultados das recuperações nos gráficos não são claros devido à grande quantidade de informações apresentadas, as recuperações dos testes de flotação dos artigos da análise bibliométrica estão detalhados nos itens 3.15 .1 até o item 3.15.29.

Em virtude do predomínio dos artigos em realizarem testes de flotação com minerais puros, as análises químicas e outras análises mais especificas não compõem os itens de 3.15.1 até o item 3.15.29. Os resultados das recuperações na flotação foram retirados dos gráficos apresentados pelos autores dos artigos estudados (dados estimados).

\subsubsection{DTAC - Cloreto de dodeciltrimetil amônio (Sal quaternário de amônio)}

Nos testes de flotação com o coletor DTAC, quatro artigos estudaram o reagente como coletor de caulinita. Os artigos são de número: 1,3,23 e 33 .

$\mathrm{O}$ artigo de número 1 trabalha com três diferentes frações de tamanho do mineral de caulinita em uma concentração de $4 \times 10^{-4} \mathrm{~mol} / \mathrm{L}$. A fração de tamanho de $0,1+0,075 \mathrm{~mm}$ a recuperação aumenta na proporção que o pH fica mais ácido. Nessa mesma granulometria foram encontradas recuperações que atingem o valor de $97 \%$ em pH entre 2 e 3 e recuperações de apenas $10 \%$ em pH próximo dos valores de 8 e 
9. O mesmo acontece nas frações granulométricas entre $-0,075+0,045 \mathrm{~mm}$, onde foram encontradas recuperações $95 \%$ do mineral de caulinita na faixa de $\mathrm{pH}$ entre 2 e 3, e recuperações de apenas $5 \%$ em um pH próximo de 11. Já na fração de tamanho de $-0,045 \mathrm{~mm}$ as recuperações foram mais lineares independente do $\mathrm{pH}$ trabalhado, os valores mais altos não ultrapassaram $56 \%$ e os mais baixos $40 \%$.

O artigo de número 3 utiliza o DTAC em uma concentração igual a $0,2 \mathrm{mMol} / \mathrm{L}$ e encontra a mesma lógica de flotabilidade do artigo anterior, a flotabilidade da caulinita aumenta conforme diminui o $\mathrm{pH}$ (tabela 9).

Tabela 9: Resultados dos resultados de recuperação nos testes de flotação para o coletor DTAC para o artigo de número 3 (Elaboração própria)

\begin{tabular}{cc}
\multicolumn{2}{c}{ Caulinita - Coletor DTAC } \\
\hline $\mathrm{pH}$ & Recuperação (\%) \\
\hline $2-3$ & 70 \\
$4-5$ & 78 \\
$5-6$ & 73 \\
8 & 65 \\
9,5 & 52 \\
11 & 45 \\
\hline
\end{tabular}

O artigo 23 trabalhou com 0,2Mm/L de DTAC e as recuperações foram as seguintes apresentadas na tabela 10 . 
Tabela 10: Resultados dos resultados de recuperação nos testes de flotação para o coletor DTAC para o artigo de número 23 (Elaboração própria)

\begin{tabular}{cc}
\multicolumn{2}{c}{ Caulinita - Coletor DTAC } \\
\hline $\mathrm{pH}$ & Recuperação (\%) \\
\hline 4 & 98 \\
5,5 & 95 \\
7 & 90 \\
8,4 & 80 \\
10 & 72 \\
11,5 & 58 \\
\hline
\end{tabular}

O artigo de número 33 utilizou uma metodologia semelhante a do artigo de número 1 , utilizou três faixas granulométricas do mineral de caulinita nos testes de flotação. $A$ granulometria 0,075-0,1mm a melhor recuperação (98\%) ocorreu no pH próximo de 2,3 e a pior recuperação (próximo de $0 \%$ ) em um pH entre $10-11$. Na fração granulométrica de 4,0 X10-4 mol/L a melhor recuperação aconteceu em $\mathrm{pH}$ ácidos $(\mathrm{pH}$ 3,3 - 90\% de recuperação e $\mathrm{pH} 5,5$ - 87\% de recuperação) e as piores em pH mais alcalinos ( $\mathrm{pH}$ 10,7 - 5\% de recuperação). As recuperações da última granulometria (0 - 0,045mm) foram constantes: $\mathrm{pH} 2,5$ recuperação de 51\%, pH 3,8 recuperação de $53 \%$, pH 5 - 6 recuperações de $45 \%$, pH 7 - 8 recuperação de 56\%, pH 9,2 recuperação de $50 \%$ e pH 10 - 11 recuperações de $40 \%$.

\subsubsection{CTAC - Cloreto de cetiltrimetil amônio (Sal quaternário de amônio)}

Três artigos foram localizados para o coletor CTAC. Os artigos são os de números 1,3 e 33.

Com três diferentes granulométricas para o mineral de caulinita o artigo de número 1 trabalhou com coletor em uma concentração de $4 \times 10^{-4} \mathrm{~mol} / \mathrm{L}$. As recuperações foram altas em uma longa gama de $\mathrm{pH}$ para a fração de tamanho de - 
0,1 + 0,075 mm. Foram encontradas recuperações que atingem o valor de $98 \%(\mathrm{pH}$ entre 2 e 7), recuperações próximas de 86\% (pH 9,1) e recuperações de $78 \%$ para um $\mathrm{pH}$ superior a 11. Nas frações granulométricas entre $-0,075+0,045 \mathrm{~mm}$, foram encontradas recuperações $95 \%$ do mineral de caulinita na gama de $\mathrm{pH}$ entre 2 e 3, e recuperações de apenas $24 \%$ em um pH próximo de 11 . Já na granulometria $-0,045$ $\mathrm{mm}$ as recuperações foram extremamente baixas, não ultrapassaram o valor de $6 \%$ $(\mathrm{pH}$ 3- $\mathrm{pH} 11)$.

A recuperação da caulinita utilizando como coletor o CTAC $(0,2 \mathrm{mmol} / \mathrm{L})$ no artigo de número 3 decresce conforme aumenta o $\mathrm{pH}$. As recuperações encontradas pelos autores as descritas na tabela 11 a baixo.

Tabela 11: Resultados dos resultados de recuperação nos testes de flotação para o coletor CTAC para o artigo de número 3 (Elaboração própria)

\begin{tabular}{cc}
\multicolumn{2}{c}{ Caulinita - Coletor CTAC } \\
\hline $\mathrm{pH}$ & Recuperação (\%) \\
\hline 2,8 & 77 \\
4,6 & 80 \\
5,7 & 78 \\
7,1 & 72 \\
8,5 & 67 \\
9,7 & 56 \\
11,2 & 50 \\
\hline
\end{tabular}

O CTAC no artigo de número 33 apresentou boas recuperações para a caulinita na faixa granulométrica de 0,075 até $0,1 \mathrm{~mm}$ : $\mathrm{pH}$ de 2 - 7 recuperações próximas de $99 \%$, recuperação de $86 \%$ em um $\mathrm{pH}=9$ e recuperações de caulinita na faixa de $77 \%$ em um pH 10,5. Para faixa granulométrica entre 0,0045 até 0,075 os autores obtiveram recuperações de $96 \%$ em um pH mais ácido (2 até 4 ) e recuperações 
menores (24\%) em um meio mais básico $(\mathrm{pH} 11)$. Já na faixa granulométrica de 0 até $0,045 \mathrm{~mm}$ as recuperações foram inferiores a $10 \%$.

\subsubsection{DTAB - Brometo de dodeciltrimetil amônio (Sal quaternário de amônio)}

Os artigos de números 2 e 19 trabalham com DTAB, um sal de amônio quartanário. $\mathrm{O}$ artigo de número 2 conseguiu seu melhor resultado na concentração de $1 \times 10^{-4} \mathrm{~mol} / \mathrm{L}$ do coletor (tabela 12 ).

Tabela 12: Resultados dos resultados de recuperação nos testes de flotação para o coletor DTAB para o artigo de número 2 (Elaboração própria)

\begin{tabular}{cc}
\multicolumn{2}{c}{ Caulinita - Coletor DTAB } \\
\hline $\mathrm{pH}$ & Recuperação (\%) \\
\hline 5,2 & 94 \\
6,6 & 96 \\
7,4 & 98 \\
9,6 & 90 \\
\hline
\end{tabular}

Já o artigo de número 19 (tabela 13) trabalhou com DTAB em uma concentração igual a $2 \times 10^{-4} \mathrm{~mol} / \mathrm{L}$. 
Tabela 13: Resultados dos resultados de recuperação nos testes de flotação para o coletor DTAB para o artigo de número 19 (Elaboração própria)

Caulinita - Coletor DTAB

\begin{tabular}{cc}
\hline $\mathrm{pH}$ & Recuperação (\%) \\
\hline 4 & 99 \\
5,6 & 98 \\
7 & 88 \\
8,4 & 78 \\
10 & 73 \\
11,5 & 57 \\
\hline
\end{tabular}

\subsubsection{AQ142 -Tomamine (Sal quaternário de amônio)}

Os autores do artigo de número 2 trabalharam com um novo reagente para flotação de caulinita denominado Tomamine Q-14-2 (AQ 142). O artigo apresentou resultados de flotabilidade para caulinita e hematita. Para caulinita as melhores recuperações na flotação (tabela 14) ocorreram em uma concentração do coletor de $1 \times 10^{-4} \mathrm{M}$.

Tabela 14: Resultados dos resultados de recuperação nos testes de flotação para o coletor AQ142 para o artigo de número 2 (Elaboração própria)

\begin{tabular}{cc} 
& Caulinita - Coletor AQ142 \\
\hline $\mathrm{pH}$ & Recuperação (\%) \\
\hline 4 & 70 \\
6 & 80 \\
8 & 90 \\
10 & 99 \\
\hline
\end{tabular}


O artigo utilizou amido de milho para alcançar a seletividade entre caulinita e hematita. Em um pH igual a 10 e com $1 \times 10^{-4} \mathrm{~mol} / \mathrm{L}$ mais o amido de milho a seletividade atingida foi de $60 \%$ entre os dois minerais.

\subsubsection{CTAB - Brometo de cetiltrimetil amônio - sal de amônio quaternário}

Os autores do artigo de número 6 encontraram a melhor flotabilidade (tabela 15) para o mineral de caulinita em meio ácido a uma concentração de $0,2 \mathrm{Mm}$ de CTAB.

Tabela 15: Resultados dos resultados de recuperação nos testes de flotação para o coletor CTAB para o artigo de número 6 (Elaboração própria)

\begin{tabular}{cc} 
& Caulinita - Coletor CTAB \\
\hline $\mathrm{pH}$ & Recuperação (\%) \\
\hline 2 & 76 \\
5 & 79 \\
6,5 & 74 \\
7,1 & 70 \\
9 & 59 \\
10,8 & 49 \\
\hline
\end{tabular}

O estudo do artigo de número 8 trabalhou com CTAB $\left(2 \times 10^{-4}\right)$ em dois caulins de comportamento diferentes, denominado caulim duro e caulim mole. Os resultados das recuperações nos testes de flotação estão na tabela 16. 
Tabela 16: Resultados dos resultados de recuperação nos testes de flotação para o coletor CTAB para o artigo de número 8 (Elaboração própria)

Caulim - Coletor CTAB

\begin{tabular}{cccc}
\hline $\mathrm{pH}$ & Soft - Recuperação (\%) & $\mathrm{pH}$ & Hard - Recuperação (\%) \\
\hline 2,4 & 95 & 2,3 & 75 \\
5 & 88 & 4,8 & 78 \\
6,7 & 81 & 6,5 & 75 \\
8,7 & 71 & 8,7 & 57 \\
10,4 & 66 & 11,0 & 42 \\
\hline
\end{tabular}

\subsubsection{BDDA ou 12-4-12 - Brometo de dimetildodecil amônio dissubstituído - Sal de amônio quaternário}

O coletor 12-4-12 (Artigo 14) foi empregado na flotação reversa de diásporo (flotou-se o mineral de caulinita) e como agente depressor do diásporo foi usado uma solução de amido. Os testes de flotação foram realizados em duas condições, a primeira com o depressor $(180 \mathrm{mg} / \mathrm{L})$ e o coletor $(0,2 \mathrm{mM})$ e chegou-se nos resultados mostrados na tabela 17.

Tabela 17: Resultados dos resultados de recuperação nos testes de flotação para o coletor 12-4-12 mais amido para o artigo de número 14 (Elaboração própria)

Coletor 12-4-12, Amido

\begin{tabular}{ccc}
\hline $\mathrm{pH}$ & (Caulinita) Recuperação (\%) & (Diásporo) Recuperação (\%) \\
\hline 2,2 & 73 & 34 \\
4 & 68 & 33 \\
6 & 67 & 23 \\
7,9 & 63 & 13 \\
10,1 & 59 & 8 \\
12 & 52 & 10 \\
\hline
\end{tabular}


Sem amido tanto os minerais de caulinita como os de diásporo flotaram muito bem, os resultados da flotação de caulinita estão apresentados na tabela 18.

Tabela 18: Resultados dos resultados de recuperação nos testes de flotação para o coletor 12-4-12 para o artigo de número 14 (Elaboração própria)

Coletor 12-4-12

\begin{tabular}{ccc}
\hline $\mathrm{pH}$ & Recuperação (\%) & (Diásporo) \\
\hline 2,2 & 98 & 99 \\
4 & 98 & 99 \\
6 & 98 & 99 \\
7,9 & 97 & 99 \\
10,1 & 94 & 99 \\
12 & 79 & 81 \\
\hline
\end{tabular}

O artigo de número 19 trabalhou com o coletor de sigla 12-4-12 em uma concentração de $2,0 \times 10^{-4} \mathrm{~mol} / \mathrm{L}$. Os autores atingiram uma excelente recuperação na flotação para o mineral de caulinita, os resultados dos ensaios de flotabilidade foram: recuperação de $98 \%$ do pH 2 até o pH 10 e recuperação de $80 \%$ em um pH igual a 12 .

O estudo realizado pelos autores do artigo de número 25 utilizou como coletor nos testes de flotação do mineral de caulinita o reagente BDDA em uma concentração de $2 \times 10^{-4} \mathrm{~mol} / \mathrm{L}$ (tabela 19 ). 
Tabela 19: Resultados dos resultados de recuperação nos testes de flotação para o coletor BDDA para o artigo de número 25 (Elaboração própria)

Caulinita - Coletor BDDA

\begin{tabular}{cc}
\hline $\mathrm{pH}$ & Recuperação (\%) \\
\hline 2 & 98 \\
8 & 95 \\
10 & 87 \\
12 & 80 \\
\hline
\end{tabular}

Os autores do artigo 34 usaram como coletor 12-4-12 para flotar caulinita. Nos testes de flotação onde apenas o agente coletor foi adicionado as recuperações foram mais altas e estão representadas na tabela 20.

Tabela 20: Resultados dos resultados de recuperação nos testes de flotação para o coletor 12-4-12 para o artigo de número 34 (Elaboração própria)

Coletor $12-4-12$

\begin{tabular}{ccc}
\hline $\mathrm{pH}$ & Recuperação (\%) - Caulinita & Recuperação (\%) - Diásporo \\
\hline 2 & 98 & 99 \\
4 & 98 & 99 \\
6 & 98 & 99 \\
8 & 97 & 99 \\
10 & 94 & 99 \\
12 & 79 & 80 \\
\hline
\end{tabular}

Nos testes de flotação onde o coletor e o amido foram testados juntos as recuperações foram menores (tabela 21). 
Tabela 21: Resultados dos resultados de recuperação nos testes de flotação para o coletor 12-4-12 mais depressor para o artigo de número 34 (Elaboração própria)

Caulinita - Coletor 12-4-12 mais depressor

\begin{tabular}{ccc}
\hline $\mathrm{pH}$ & Recuperação (\%) - Caulinita & Recuperação (\%) - Diásporo \\
\hline 2 & 73 & 54 \\
4 & 68 & 53 \\
6 & 68 & 24 \\
8 & 62 & 13 \\
10 & 60 & 9 \\
12 & 51 & 10 \\
\hline
\end{tabular}

Os autores descrevem que em $\mathrm{pH}$ alcalino o amido tem um forte efeito depressivo para diásporo.

\subsubsection{DDTA- Sal de amônio (radical alquila) - Sal de amônio quaternário}

O DDTA foi empregado nos testes de flotação do artigo de número 16. Os valores encontrados pelos autores estão apresentados na tabela 22.

Tabela 22: Resultados dos resultados de recuperação nos testes de flotação para o coletor DDTA para o artigo de número 16 (Elaboração própria)

Caulinita - Coletor DDTA

\begin{tabular}{cc}
\hline $\mathrm{pH}$ & Recuperação (\%) \\
\hline 2,4 & 70 \\
3,8 & 76 \\
4,2 & 78 \\
6,4 & 73 \\
8 & 65 \\
9,6 & 52 \\
11,2 & 46 \\
\hline
\end{tabular}


Os resultados encontrados na flotação de caulinita pelos autores do artigo de 24 foram semelhantes aos resultados do artigo 34. Para BDDA em uma concentração de $2 \times 10^{-4} \mathrm{M}$ os resultados foram: $98 \%$ em um pH de 2 a $6,96 \%$ para o $\mathrm{pH} 8,94 \%$ para o ph 10 e $80 \%$ para o pH 12 .

\subsubsection{DDGS - Sulfato de dodecilguanidina - Sal de amônio quaternário}

O artigo de número 23 trabalhou DDGS em uma concentração de 0,2 Mm (tabela 23). Observa-se a máxima recuperação de caulinita em pH igual a 4.

Tabela 23: Resultados dos resultados de recuperação nos testes de flotação para o coletor DDGS para o artigo de número 23 (Elaboração própria)

\begin{tabular}{cc} 
& Caulinita - Coletor DDGS \\
\hline $\mathrm{pH}$ & Recuperação (\%) \\
\hline 4 & 97 \\
5,5 & 93 \\
7 & 92 \\
8,6 & 83 \\
10 & 75 \\
11,4 & 71 \\
\hline
\end{tabular}

\subsubsection{EDDA - Brometo dodecildimetil amônio - Sal de amônio quaternário}

O EDDA, foi o coletor escolhido no artigo 25 , usou-se uma concentração de $2 \times 10^{-4} \mathrm{~mol} / \mathrm{L}$. Os valores de recuperação mostram uma queda de flotabilidade para o mineral de caulinita com o aumento do $\mathrm{pH}$, os valores são apresentados na tabela 24 . 
Tabela 24: Resultados dos resultados de recuperação nos testes de flotação para o coletor DDA para o artigo de número 25 (Elaboração própria)

Caulinita - Coletor EDDA

\begin{tabular}{cc}
\hline $\mathrm{pH}$ & Recuperação (\%) \\
\hline 2 & 87 \\
4 & 86 \\
6 & 81 \\
8 & 79 \\
10 & 75 \\
12 & 63 \\
\hline
\end{tabular}

Os autores mostram que aumentando a dosagem do coletor de $1 \times 10^{-4} \mathrm{~mol} / \mathrm{L}$ para $3,5 \times 10^{-4} \mathrm{~mol} / \mathrm{L}$ a recuperação da caulinita em um pH igual a 8 cresce de $50 \%$ para $99,7 \%$.

\subsubsection{C - Dodeciltrimetil amônio - Sal de amônio quaternário}

O artigo de número 33 realizou testes de flotação com caulinita em diferentes frações de tamanho de partícula $(0,075-0,1 \mathrm{~mm}, 0,045-0,075 \mathrm{~mm}, 0-0,045 \mathrm{~mm}) \mathrm{com}$ o coletor $103 \mathrm{C}$ em uma concentração de $4 \times 10^{-4} \mathrm{~mol} / \mathrm{L}$. Os resultados obtidos pelo autor mostram que com o aumento do pH há uma diminuição na recuperação para todas as três frações de tamanho de partícula do mineral de caulinita. Os resultados obtidos são apresentados na tabela 25. 
Tabela 25 - Recuperação na flotação do mineral de caulinita em três diferentes frações de tamanho em uma concentração de $4 \times 10^{-4} \mathrm{~mol} / \mathrm{L}$ de $103 \mathrm{C}$ para o artigo 33 (Elaboração própria).

\begin{tabular}{cc|cc|cc}
\multicolumn{2}{c|}{$0,075-0,1 \mathrm{~mm}$} & \multicolumn{2}{c|}{$0,045-0,075 \mathrm{~mm}$} & \multicolumn{2}{c}{$0-0,045 \mathrm{~mm}$} \\
\hline $\mathrm{pH}$ & Recuperação \% & $\mathrm{pH}$ & Recuperação \% & $\mathrm{pH}$ & Recuperação \% \\
\hline 3,1 & 91 & 2,3 & 91 & 2,5 & 70 \\
4,4 & 88 & 4,7 & 78 & 3,9 & 71 \\
6 & 50 & 6,6 & 43 & 5,2 & 72 \\
7,1 & 20 & 9 & 9 & 7,4 & 68 \\
8,9 & 0 & 10,7 & 4 & 8,7 & 70 \\
10,3 & 0 & & & 10,8 & 60 \\
\hline
\end{tabular}

Através do gráfico observa-se que existe uma diferença de comportamento entre as três frações de tamanho apresentadas, principalmente quando se compara as frações de 0,075 - 0,1 mm e 0,045 -0,075 mm com fração de $0-0,045 \mathrm{~mm}$.

\subsubsection{TTAC - Cloreto de tetradeciltrimetil amônio - Sal de amônio quaternário}

Os estudos do artigo de número 33 envolveram um segundo coletor, o sal de amônio quartenário, denominado como TTAC. Conforme a tabela 26 a caulinita apresenta uma ótima flotabilidade em meio ácido nas frações 0,075 - 0,1 mm e 0,045 $-0,075$. Já nas frações menores $(0-0,045 \mathrm{~mm})$ a flotabilidade diminui em todos os valores de $\mathrm{pH}$, embora os maiores valores de recuperação continuem no meio ácido. 
Tabela 26 - Recuperação na flotação do mineral de caulinita em três diferentes frações de tamanho em uma concentração de $4 \times 10^{-4} \mathrm{~mol} / \mathrm{L}$ de TTAC (Artigo 33)

(Elaboração própria).

\begin{tabular}{cc|cc|cc}
\multicolumn{2}{c|}{$0,075-0,1 \mathrm{~mm}$} & \multicolumn{2}{c|}{$0,045-0,075 \mathrm{~mm}$} & \multicolumn{2}{c}{$0-0,045 \mathrm{~mm}$} \\
\hline $\mathrm{pH}$ & Recuperação \% & $\mathrm{pH}$ & Recuperação \% & $\mathrm{pH}$ & Recuperação \% \\
\hline 2,8 & 99 & 2,9 & 96 & 2,3 & 39 \\
3,8 & 99 & 4,4 & 92 & 3,6 & 33 \\
5,7 & 97 & 6,5 & 80 & 4,9 & 24 \\
7,9 & 91 & 8,7 & 66 & 7,2 & 26 \\
9,1 & 80 & 10,4 & 20 & 8,4 & 21 \\
10,4 & 36 & & & 10,4 & 16 \\
\hline
\end{tabular}

\subsubsection{Vinte diferentes sais de amônio quaternários (20Q)}

O artigo de número 38 trabalhou com vinte diferentes sais de amônio quaternários como coletores para o mineral de caulinita. A fórmula molecular de cada coletor está representada na figura 33. Os autores dividiram os reagentes em três séries:

- Radical graxo com um agrupamento alquil: 0831, 1031, 1231, 1222, 1227 , 1431, 1427, 1631, 1622, 1627, 1831.

- Radical graxo com dois agrupamentos alquil: D8, D10, D12, D16, D18.

- Com três radicais graxo: T4, T8, T12, F4. 


\begin{tabular}{ll}
\hline Coletores & Fórmula molecular \\
\hline 0831 & $\mathrm{C}_{8} \mathrm{H}_{17}\left(\mathrm{CH}_{3}\right)_{3} \mathrm{NCl}$ \\
1031 & $\mathrm{C}_{10} \mathrm{H}_{21}\left(\mathrm{CH}_{3}\right)_{3} \mathrm{NCl}$ \\
1231 & $\mathrm{C}_{12} \mathrm{H}_{25}\left(\mathrm{CH}_{3}\right)_{3} \mathrm{NCl}$ \\
1222 & $\mathrm{C}_{12} \mathrm{H}_{25} \mathrm{C}_{2} \mathrm{H}_{5}(\mathrm{CH})_{2} \mathrm{NCl}$ \\
1227 & $\left.\left.\mathrm{C}_{12} \mathrm{H}_{25} \mathrm{C}_{6} \mathrm{H}_{5} \mathrm{CH}_{3}\right)_{2} \mathrm{CH}_{3}\right)_{2} \mathrm{NCl}$ \\
1431 & $\mathrm{C}_{14} \mathrm{H}_{29}\left(\mathrm{CH}_{3}\right)_{3} \mathrm{NCl}$ \\
1427 & $\mathrm{C}_{14} \mathrm{H}_{29} \mathrm{C}_{6} \mathrm{H}_{5} \mathrm{CH}_{3}\left(\mathrm{CH}_{3}\right)_{2} \mathrm{NCl}$ \\
1631 & $\mathrm{C}_{16} \mathrm{H}_{33}\left(\mathrm{CH}_{3}\right)_{3} \mathrm{NCl}$ \\
1622 & $\mathrm{C}_{16} \mathrm{H}_{33} \mathrm{C}_{2} \mathrm{H}_{5}\left(\mathrm{CH}_{3}\right)_{2} \mathrm{NCl}$ \\
1627 & $\left.\mathrm{C}_{16} \mathrm{H}_{33} \mathrm{C}_{6} \mathrm{H}_{5} \mathrm{CH}_{3} \mathrm{CH}_{3}\right)_{2} \mathrm{NCl}$ \\
1831 & $\mathrm{C}_{18} \mathrm{H}_{37}\left(\mathrm{CH}_{3}\right)_{3} \mathrm{NCl}$ \\
D8 & $\left(\mathrm{C}_{8} \mathrm{H}_{17}\right)_{2}\left(\mathrm{CH}_{3}\right)_{2} \mathrm{NCl}$ \\
D10 & $\left(\mathrm{C}_{10} \mathrm{H}_{21}\right)_{2}\left(\mathrm{CH}_{3}\right)_{2} \mathrm{NCl}$ \\
D12 & $\left(\mathrm{C}_{12} \mathrm{H}_{25}\right)_{2}\left(\mathrm{CH}_{3}\right)_{2} \mathrm{NCl}$ \\
D16 & $\left(\mathrm{C}_{16} \mathrm{H}_{33}\right)_{2}\left(\mathrm{CH}_{3}\right)_{2} \mathrm{NCl}$ \\
D18 & $\left(\mathrm{C}_{18} \mathrm{H}_{37}\right)_{2}\left(\mathrm{CH}_{3}\right)_{2} \mathrm{NCl}$ \\
T4 & $\left(\mathrm{C}_{4} \mathrm{H}_{9}\right)_{3} \mathrm{CH}_{3} \mathrm{NCl}$ \\
T8 & $\left(\mathrm{C}_{8} \mathrm{H}_{17}\right)_{3} \mathrm{CH}_{3} \mathrm{NCl}$ \\
T12 & $\left(\mathrm{C}_{12} \mathrm{H}_{25}\right)_{3} \mathrm{CH}_{3} \mathrm{NCl}$ \\
F4 & $\left(\mathrm{C}_{4} \mathrm{H}_{9}\right)_{4} \mathrm{NCl}$ \\
\hline
\end{tabular}

Figura 33 - Fórmula molecular dos vinte sais de amônio quarternário (YUEHUA HU et al, 2012).

Os autores os coletores 1031, 1231, D8 e F4 possuem apresentam seletividades na flotação. Os resultados obtidos pelos autores estão apresentados na figura 34 . 

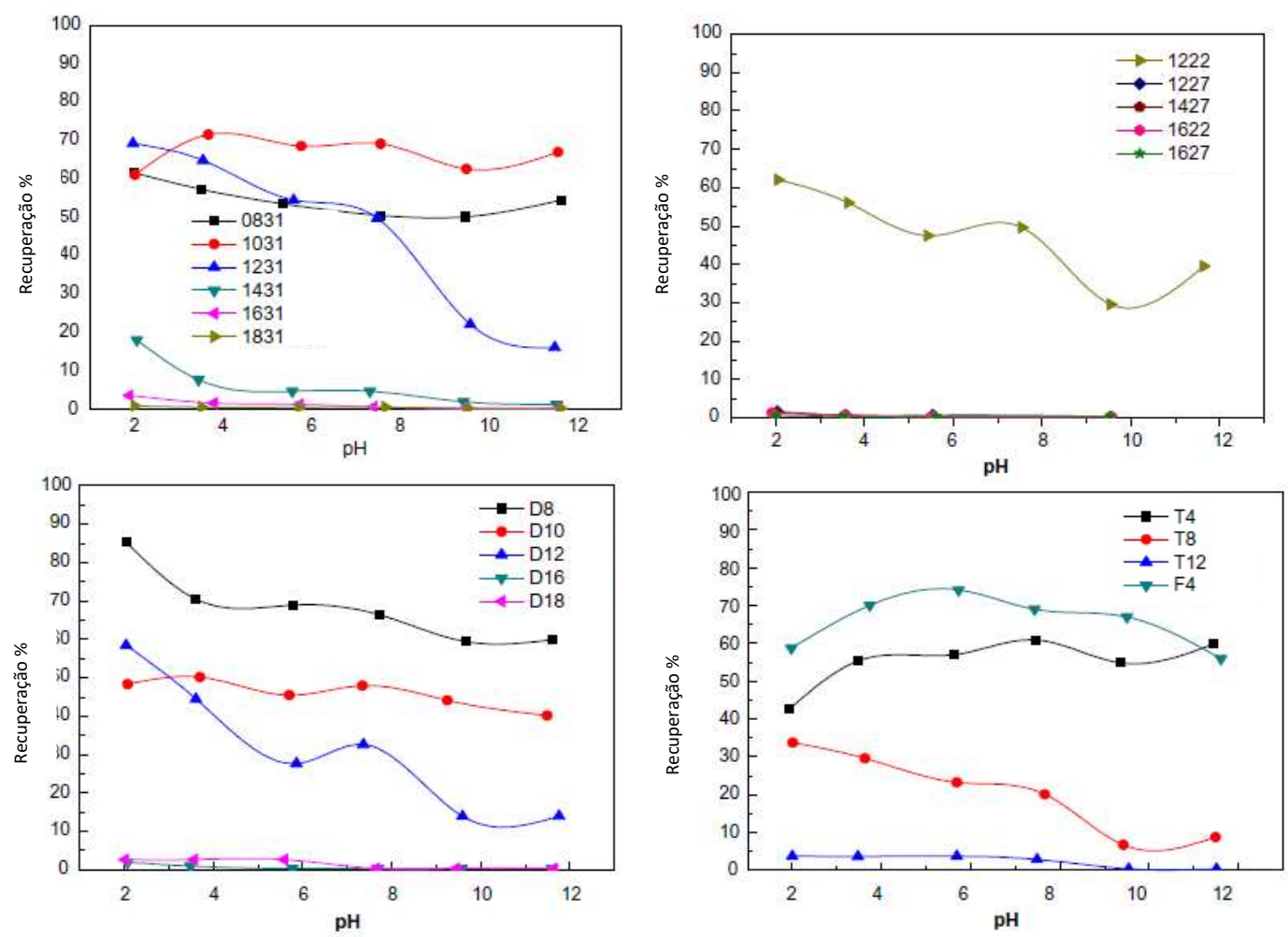

Figura 34 - Recuperação do mineral de caulinita na flotação com vinte diferentes sais de amônio quaternário (2×10-4 mol/L) (YUEHUA HU et al, 2012).

\subsubsection{Flotigam EDA - Éter-amina}

Os autores brasileiros do artigo de número 2 trabalharam com uma éter-amina (Flotigam EDA) para separar o mineral de caulinita do mineral de hematita. Os melhores resultados foram obtidos em uma concentração do coletor de $1 \times 10^{-4} \mathrm{M}$ e em $\mathrm{pH}$ mais alcalino (tabela 27). 
Tabela 27: Resultados dos resultados de recuperação nos testes de flotação para o coletor Flotigam EDA para o artigo de número 2 (Elaboração própria)

Caulinita - Coletor EDA

\begin{tabular}{cc}
\hline $\mathrm{pH}$ & Recuperação (\%) \\
\hline 4 & 57 \\
6 & 65 \\
7 & 92 \\
10,2 & 98 \\
\hline
\end{tabular}

O artigo ainda salienta que a separação dos dois minerais (caulinita e hematita) não é possível na ausência do depressor (amido de milho).

\subsubsection{Flotigam EDA 3 - Éter-monoamina}

O trabalho de número 10 utilizou como coletor a éter-monoamina (Flotigam EDA 3). Conforme o artigo, a éter-monoamina provoca uma alta flotação do mineral de caulinita, especialmente em soluções ácidas, mas em altas dosagens do coletor (tabela 28).

Tabela 28: Resultados dos resultados de recuperação nos testes de flotação para o coletor EDA 3 para o artigo de número 10 (Elaboração própria)

Caulinita - Coletor EDA 3

\begin{tabular}{cc}
\hline $\mathrm{pH}$ & Recuperação (\%) \\
\hline 3 & 87 \\
4,8 & 90 \\
6 & 73 \\
8 & 70 \\
10 & 68 \\
10,6 & 64 \\
\hline
\end{tabular}


De acordo com os autores do artigo de número 10 aumentado à força iônica do meio com $0,5 \mathrm{M}$ de $\mathrm{NaCl}$, a recuperação da caulinita aumenta para $89 \%$ a um $\mathrm{pH}$ 10 e uma dosagem de $400 \mathrm{~g} / \mathrm{t}$ de coletor.

\subsubsection{Flotigam 2835 (2L) - Éter-Diamina}

O coletor Flotigam 2835 foi estudado através de testes de flotação para flotar o mineral de caulinita no artigo de número 10. Conforme os resultados do artigo os autores observaram que o Flotigam 2835-2L não induziu qualquer flotação para o mineral de caulinita em uma larga gama de $\mathrm{pH}$ de 3 a 10,5 e a flotabilidade diminui com o aumento do $\mathrm{pH}$. Os valores apresentados no trabalho foram:

- Éter- diamina (400g/t): pH 3 recuperação de $16 \%, \mathrm{pH} 3$ recuperação de $16 \%$ e pH 5 recuperação de $0 \%$.

- Éter- diamina (300g/t): pH 3 recuperação de 10,5\%, pH 4 recuperação de $11,5 \%$ e pH 5 recuperação de $0 \%$.

- Éter- diamina (200g/t): $\mathrm{pH} 3$ recuperação de 6,8\%, pH 4 recuperação de $4,8 \%$ e pH 5 recuperação de $0 \%$.

- Éter- diamina (100g/t): pH 3 recuperação de 3\%, pH 4 recuperação de $2 \%$ e pH 5 recuperação de $0 \%$.

Aumentando a força iônica do meio com uma solução de $0,5 \mathrm{M}$ de $\mathrm{NaCl}$ a recuperação da caulinita com $400 \mathrm{~g} / \mathrm{t}$ de éter-diamina cresce para 99,9\% do pH 3 até 10 e de $99,7 \%$ no $\mathrm{pH} 10,6$.

\subsubsection{Aminas terciárias}

Os artigos de número 4 e 12 trabalharam com quatro aminas terciárias: DRN, DEN, DPN DBN. Já o artigo de número 32 trabalhou com três aminas terciárias: DRN, DEN e DPN. 
Os estudos dos três artigos (4,12 e 15) foram semelhantes e obtiveram resultados muito próximos. Conforme os autores de número 4 e 12 o coletor DBN apresentou a pior flotabilidade para o mineral de caulinita comparado com os restantes dos coletores. Já o coletor DEN apresentou a melhor flotabilidade do mineral de caulinita comparado com as ouras aminas terciárias. A recuperação do mineral de caulinita na flotação aumenta da seguinte forma DEN > DPN >DRN > DBN. Para as quatro aminas terciárias a recuperação na flotação diminui em polpas mais alcalinas. Os resultados das recuperações nos testes de flotação das aminas terciárias são encontrados nas tabelas 29, 30, 31, 32 e 33 .

$\mathrm{O}$ artigo de número 15 usou como agente coletor $\mathrm{PN}$, os resultados estão descritos na tabela 33 .

Tabela 29: Resultados dos resultados de recuperação nos testes de flotação para o coletor DRN para os artigos de número 4,12 e 32 (Elaboração própria)

\begin{tabular}{cc} 
& Caulinita - Coletor DRN \\
\hline $\mathrm{pH}$ & Recuperação (\%) \\
\hline 2,6 & 88 \\
4,4 & 84 \\
5,2 & 78 \\
6 & 76 \\
8 & 64 \\
10 & 52 \\
11,2 & 24 \\
\hline
\end{tabular}


Tabela 30: Resultados dos resultados de recuperação nos testes de flotação para o coletor DEN para os artigos de número 4,12 e 32 (Elaboração própria)

\begin{tabular}{cc} 
& Caulinita - Coletor DEN \\
\hline $\mathrm{pH}$ & Recuperação (\%) \\
\hline 2,5 & 94 \\
3,4 & 92 \\
4,1 & 91 \\
5,5 & 89 \\
6 & 90 \\
8 & 87 \\
10,2 & 77 \\
11,6 & 56 \\
\hline
\end{tabular}

Tabela 31: Resultados dos resultados de recuperação nos testes de flotação para o coletor DPN para os artigos de número 4,12 e 32 (Elaboração própria)

\begin{tabular}{cc}
\multicolumn{2}{c}{ Caulinita - Coletor DPN } \\
\hline $\mathrm{pH}$ & Recuperação (\%) \\
\hline 1,9 & 87 \\
2,7 & 92 \\
4,2 & 86 \\
5,6 & 81 \\
7,6 & 75 \\
9,1 & 60 \\
10,6 & 46 \\
11,5 & 17 \\
\hline
\end{tabular}


Tabela 32: Resultados dos resultados de recuperação nos testes de flotação para o coletor DBN para os artigos de número 4 e 12 (Elaboração própria)

\begin{tabular}{cc} 
& Caulinita - Coletor DBN \\
\hline $\mathrm{pH}$ & Recuperação (\%) \\
\hline 1,9 & 79 \\
2,6 & 81 \\
4 & 46 \\
4,7 & 42 \\
8 & 28 \\
10,4 & 8 \\
11,8 & 4 \\
\hline
\end{tabular}

Tabela 33: Resultados dos resultados de recuperação nos testes de flotação para o coletor PN para o artigo de número 15 (Elaboração própria)

Caulinita - Coletor PN

\begin{tabular}{cc}
\hline $\mathrm{pH}$ & Recuperação $(\%)$ \\
\hline 2 & 88 \\
3 & 90 \\
4,2 & 87 \\
5,6 & 82 \\
7,6 & 75 \\
9,2 & 60 \\
10,7 & 47 \\
11,6 & 18 \\
\hline
\end{tabular}




\subsubsection{DDA - Acetato de dodecilamina - Amina primária}

Uma amina primária foi selecionada como agente coletor para flotação no artigo de número 11, DDA. Os valores de recuperação mostram uma queda de flotabilidade para o mineral de caulinita com o aumento do pH (tabela 34). Não foram encontrados dados sobre a dosagem do coletor.

Tabela 34: Resultados dos resultados de recuperação nos testes de flotação para o coletor DDA para o artigo de número 11 (Elaboração própria)

Caulinita - Coletor DDA

\begin{tabular}{cc}
\hline $\mathrm{pH}$ & Recuperação (\%) \\
\hline 2 & 73 \\
3,6 & 65 \\
4 & 60 \\
4,8 & 45 \\
6,5 & 17 \\
8,5 & 13 \\
9,4 & 11 \\
11,1 & 13 \\
\hline
\end{tabular}

Além do coletor DDA, os autores do artigo de número 11 acrescentaram um derivado de poliacrilamidas aniônico (APAM) na flotação do mineral de caulinita. Os resultados mostram um considerável aumento na flotabilidade do mineral de caulinita em uma ampla faixa de $\mathrm{pH}$ (tabela 35). 
Tabela 35: Resultados dos resultados de recuperação nos testes de flotação para o coletor DDA mais APAM para o artigo de número 11 (Elaboração própria)

\begin{tabular}{cc}
\multicolumn{2}{c}{ Caulinita - Coletor DDA + APAM } \\
\hline $\mathrm{pH}$ & Recuperação (\%) \\
\hline 3,1 & 93 \\
4,2 & 94 \\
5,5 & 84 \\
7,4 & 79 \\
8,3 & 79 \\
9,4 & 77 \\
10,2 & 74 \\
\hline
\end{tabular}

\subsubsection{DC- Cloreto de dodecilamina - Amina primária}

O artigo de número 37 utiliza o $\mathrm{DC}$ em uma concentração igual a $2 \times 10^{-4} \mathrm{M}$. Os dados utilizando pelo artigo de número 37 sobre a flotação de caulinita foram retirados de outro artigo desenvolvido por Hu et al (2005) (tabela 36). 
Tabela 36: Resultados dos resultados de recuperação nos testes de flotação para o coletor DC para o artigo de número 37 (Elaboração própria)

\begin{tabular}{cc} 
& Caulinita - Coletor DC \\
\hline $\mathrm{pH}$ & Recuperação (\%) \\
\hline 2 & 67 \\
4 & 65 \\
5 & 44 \\
6,4 & 16 \\
8,8 & 13 \\
9,8 & 14 \\
11,2 & 11 \\
\hline
\end{tabular}

\subsubsection{Dodecilamina - Amina primária}

Os artigos de número 5, 16, 31 e 30 trabalharam com o coletor denominado dodecilamina. Os resultados obtidos em uma concentração de reagente de 0,2 mM para o artigo de número 16 estão apresentados na tabela 37 . Já os resultados do artigo de número 5 estão descritos na tabela 38. Nos quatro artigos a maior flotabilidade da caulinita foi alcançada em meio ácido. 
Tabela 37: Resultados dos resultados de recuperação nos testes de flotação para o coletor DDA para o artigo de número 16 (Elaboração própria)

\begin{tabular}{cc}
\multicolumn{2}{c}{ Caulinita - Coletor DDA } \\
\hline $\mathrm{pH}$ & Recuperação $(\%)$ \\
\hline 2,3 & 73 \\
3,9 & 77 \\
5,5 & 74 \\
6,9 & 65 \\
8,7 & 57 \\
10,5 & 50 \\
\hline
\end{tabular}

Tabela 38: Resultados dos resultados de recuperação nos testes de flotação para o coletor DDA para o artigo de número 5 (Elaboração própria)

Coletor DDA

\begin{tabular}{cccc}
\hline $\mathrm{PH}$ & Recuperação (\%) & $\mathrm{pH}$ & Diásporo - Recuperação (\%) \\
\hline 2,3 & 80 & 2 & 63 \\
4,1 & 74 & 4,4 & 79 \\
6,4 & 73 & 6,2 & 93 \\
9,2 & 75 & 8,3 & 98 \\
10 & 71 & 10,2 & 93 \\
11,6 & 31 & 11,8 & 1 \\
\hline
\end{tabular}

Além da dodecilamina os autores do artigo de número 5 utilizaram em um segundo momento o depressor amido de milho (WMS). O objetivo nesse momento foi deprimir o mineral de diásporo. Os resultados obtidos pelos autores foram satisfatórios, visto que, o diásporo deprimiu por completamente em um pH de 2 até 6,5 e a caulinita sofreu um leve aumento na sua flotabilidade. Os resultados da recuperação na flotação do mineral de caulinita utilizando como agente coletor o 
dodecilamina $\left(6,47 \times 10^{-4} \mathrm{~mol} / \mathrm{L}\right)$ e o depressor WMS na concentração de $100 \mathrm{mg} / \mathrm{L}$ foram estão apresentados na tabela 39.

Tabela 39: Resultados dos resultados de recuperação nos testes de flotação para o coletor DDA mais WMS para o artigo de número 5 (Elaboração própria)

Coletor DDA + WMS

\begin{tabular}{ccc}
\hline $\mathrm{PH}$ & Caulinita - Recuperação (\%) & Diásporo - Recuperação (\%) \\
\hline 2,5 & 81 & 0 \\
4,3 & 77 & 0 \\
6,6 & 78 & 0 \\
9,1 & 77 & 7 \\
11,9 & 63 & 2 \\
\hline
\end{tabular}

O artigo de número 31 trabalhou com dodecilamina para flotar caulinita em uma concentração do coletor de 5,6x mol/L. A tabela 40 mostra que a melhor flotabilidade do mineral de caulinita ocorre entre o $\mathrm{pH} 5$ e 7.

Tabela 40: Resultados dos resultados de recuperação nos testes de flotação para o coletor DDA para o artigo de número 31 (Elaboração própria)

Coletor DDA

\begin{tabular}{cccc}
\hline $\mathrm{pH}$ & Caulinita - Recuperação (\%) & $\mathrm{pH}$ & Diásporo - Recuperação (\%) \\
\hline 3,5 & 75 & 3,5 & 18 \\
4,8 & 81 & 5,4 & 90 \\
6 & 87 & 6,5 & 98 \\
7,6 & 91 & 9,2 & 19 \\
8,8 & 41 & 11 & 10 \\
11,2 & 31 & 13,2 & 5 \\
12 & 30 & & \\
13 & 28 & & \\
\hline
\end{tabular}


Já na tabela 41 adicionando nos testes de flotação o ATNO como agente depressor para deprimir o diásporo. Comparando com a primeira (tabela 39) a flotabilidade da caulinita aumenta em $\mathrm{pH}$ mais alcalino. Conforme os autores do artigo 31 utilizando a dodecilamina e o depressor ATNO $\left(\mathrm{AlCl}_{3} / \mathrm{Na}_{2} \mathrm{SiO}_{3}\right)$ juntos, os minerais de caulinita e diásporo podem ser separados.

Tabela 41: Resultados dos resultados de recuperação nos testes de flotação para o coletor DDA mais ATNO para o artigo de número 31 (Elaboração própria)

Coletor DDA + ATNO

\begin{tabular}{cccc}
\hline $\mathrm{pH}$ & Recuperação (\%) & $\mathrm{pH}$ & Diásporo - Recuperação (\%) \\
\hline 4,5 & 39 & 5,6 & 12 \\
6 & 72 & 7,5 & 12 \\
7,5 & 87 & 9,5 & 11 \\
9,4 & 61 & 11,4 & 16 \\
11,2 & 58 & & \\
\hline
\end{tabular}

O artigo de número 30 mostrou no estudo o comportamento da flotação para os minerais de caulinita e diásporo em dois momentos. O primeiro momento os autores utilizaram apenas DDA como agente coletor. Os resultados são apresentados na tabela 42. 
Tabela 42: Resultados dos resultados de recuperação nos testes de flotação para o coletor DDA para o artigo de número 30 (Elaboração própria)

\begin{tabular}{cccc}
\multicolumn{4}{c}{ Coletor DDA $(0,4 \mathrm{mM})$} \\
\hline $\mathrm{pH}$ & Caulinita - Recuperação $(\%)$ & $\mathrm{pH}$ & Diásporo - Recuperação (\%) \\
\hline 1,5 & 91 & 1,6 & 91 \\
2,5 & 92 & 2,6 & 92 \\
4 & 93 & 3,9 & 93 \\
4,5 & 95 & 4,7 & 94 \\
7 & 85 & 7 & 84 \\
9,1 & 79 & 9,1 & 77 \\
10,9 & 71 & 11 & 72 \\
12,8 & 44 & 13 & 44 \\
\hline
\end{tabular}

No segundo momento os autores adicionaram nos testes de flotação além do DDA uma poliacrilamida catiônica (DA-5 CPAM) de peso molecular $1,1 \times 10^{7}$. Os resultados da flotação dos minerais de caulinita e diásporo podem ser vistos na tabela 43. O diásporo foi completamente deprimido por DA-5 entre o pH 5,5- 8 e a caulinita teve uma alta recuperação entre o pH 3 e 10.

Tabela 43: Resultados dos resultados de recuperação nos testes de flotação para o coletor DDA mais DA-5 para o artigo de número 30 (Elaboração própria)

\begin{tabular}{cccc}
\multicolumn{4}{c}{ Coletor DDA $(0,4 \mathrm{mM})+\mathrm{DA}-5\left(12 \mathrm{mg} \mathrm{L}^{-1}\right)$} \\
\hline $\mathrm{pH}$ & Caulinita - Recuperação (\%) & $\mathrm{pH}$ & Diásporo - Recuperação (\%) \\
\hline 3,7 & 93 & 4,2 & 47 \\
6,3 & 87 & 6,4 & 7 \\
7,8 & 81 & 7,5 & 0 \\
9,7 & 84 & 8,2 & 4 \\
& & 8,8 & 19 \\
& & 10,1 & 75 \\
\hline
\end{tabular}




\subsubsection{DDAC - Cloreto de dodecilamina - Amina primária}

$\mathrm{O}$ artigo de número 23 trabalhou com o reagente DDAC como agente coletor na flotação para o mineral de caulinita em uma concentração de 0,2 mM (tabela 44). Observa-se que a flotação do mineral de caulinita diminui com o aumento do $\mathrm{pH}$, em um $\mathrm{pH}>11,5$ a recuperação foi inferior a $40 \%$.

Tabela 44: Resultados dos resultados de recuperação nos testes de flotação para o coletor DDAC para o artigo de número 23 (Elaboração própria)

\begin{tabular}{cc} 
& Caulinita - Coletor DDAC \\
\hline $\mathrm{pH}$ & Recuperação (\%) \\
\hline 3,7 & 83 \\
5,6 & 70 \\
7,4 & 65 \\
9,1 & 64 \\
10,7 & 48 \\
11,8 & 40 \\
\hline
\end{tabular}

\subsubsection{ADPA - N-(3-aminopropil)-dodecamida- Amida}

O coletor ADPA foi empregado nos testes de flotação do artigo de número 18. Os resultados de recuperação na flotação do mineral de caulinita não ultrapassaram a margem de $80 \%$ em uma concentração de $5 \times 10^{-2} \mathrm{gL}^{-1}$ (tabela 45 ). 
Tabela 45: Resultados dos resultados de recuperação nos testes de flotação para o coletor ADPA para o artigo de número 18 (Elaboração própria)

Caulinita - Coletor ADPA

\begin{tabular}{cc}
\hline $\mathrm{pH}$ & Recuperação $(\%)$ \\
\hline 2,5 & 78 \\
3,8 & 80 \\
4,6 & 78 \\
6,4 & 76 \\
7,7 & 74 \\
8,5 & 71 \\
9,6 & 68 \\
10,5 & 66 \\
11 & 65 \\
\hline
\end{tabular}

\subsubsection{NHOD - N-(6-(hidroxiamino)-6-oxo-hexil) decanamida- Amida}

Os autores do artigo de número 35 obtiveram recuperações de caulinita extremamente baixas nos testes de flotação utilizando como agente coletor o reagente NHOD. Os resultados das recuperações estão apresentados na tabela 46.

Tabela 46: Resultados dos resultados de recuperação nos testes de flotação para o coletor NHOD para o artigo de número 35 (Elaboração própria)

Caulinita - Coletor NHOD

\begin{tabular}{cc}
\hline $\mathrm{pH}$ & Recuperação (\%) \\
\hline 2 & 3 \\
4 & 13 \\
7 & 22 \\
9 & 20 \\
12 & 22 \\
\hline
\end{tabular}




\subsubsection{AENA N-(2-aminoetill)1 naftaleno acetamida - Amida}

O artigo de número 21 não apresenta gráfico sobre a recuperação na flotação do mineral de caulinita com o coletor AENA na concentração de $5 \times 10^{-2} \mathrm{~g} / \mathrm{l}^{-1}$. No texto apresentado pelos autores à única informação sobre a flotação de caulinita é de que a melhor recuperação foi de $39 \%$ e ocorreu entre o pH 5 - 6 .

\subsubsection{4 - Derivados de Ácidos Carboxílicos}

Os artigos de número 22, 27, 28, 39 trabalharam nos ensaios de flotação utilizando como agente coletor derivados de ácidos carboxílicos. O coletor de cada artigo foi:

- Artigo 22: OCB, OHB e OTB.

- Artigo 27: BHUA, BHTA e BHPA.

- Artigo 28: HCDA, HCTA e HCHA.

- Artigo 39: CMCA, CDHA e CTHA.

A recuperação máxima do mineral de caulinita para os coletores $\mathrm{OCB}, \mathrm{OHB}$ e OTB na concentração de $2 \times 10^{-4} \mathrm{~mol} / \mathrm{L}$ foi de $35 \%$. Já os resultados das recuperações com os coletores BHUA, BHTA, BHPA, HCDA, HCTA e HCHA na concentração de $2 \times 10^{-4} \mathrm{~mol} / \mathrm{L}$ não ultrapassaram $10 \%$ entre $\mathrm{opH} 3$ até 11 . Para o coletor CDHA e CTHA a recuperação máxima atingida foi de $30 \%$, e para o coletor CMCA a recuperação foi próxima de $0 \%$.

Obs: O mineral de diásporo apresentou uma ótima flotabilidade para os coletores OCT, BHUA, BHTA, BHPA, HCDA, HCTA, HCHA, CDHA, CTHA e CMCC. 


\subsubsection{Composto nitrogenado}

O estudo envolvendo testes de flotação de caulinita apresentado pelo artigo de número 20, utilizou quatro compostos nitrogenados como coletores na

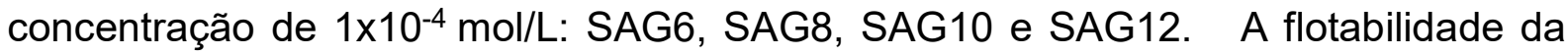
caulinita com os coletores SAG8, SAG10 e SAG12 aumenta conforme diminui o pH (tabela 47).

Tabela 47: Resultados dos resultados de recuperação nos testes de flotação para o coletor SAG8, SAG10 e SAG12 para o artigo de número 20 (Elaboração própria)

Caulinita - Coletor SAG8, SAG10 e SAG12

\begin{tabular}{cc}
\hline $\mathrm{pH}$ & Recuperação (\%) \\
\hline 4 & $>95$ \\
5,5 & $>89$ \\
7 & $>85$ \\
8,5 & $>80$ \\
10 & $>73$ \\
11,5 & $>65$ \\
\hline
\end{tabular}

A recuperação máxima atingida com o coletor SAG 6 foi de $50 \%$ em um pH = 8,5 .

\subsubsection{Oleato de sódio}

O artigo de número 16 trabalhou nos testes flotação com oleato, mas não apresentou resultados. $\mathrm{O}$ artigo descreve que com uma solução de Oleato de 0,2 mM o ângulo de contato do mineral de caulinita passou de $20^{\circ}$ para $60^{\circ}$.

Já o artigo de número 9 trabalha com oleato na flotação dos minerais de caulinita e de diásporo. Os resultados de recuperações na flotação obtidos para o 
mineral de caulinita em três frações de tamanho em uma concentração de $2 \times 10^{-4} \mathrm{M}$ de $\mathrm{NaOI}$, são apresentados na tabela 48.

Tabela 48: Resultados dos resultados de recuperação nos testes de flotação para o coletor Oleato em três faixas granulométricas para o artigo de número 16 (Elaboração própria)

Caulinita - Coletor Oleato

\begin{tabular}{cccccc}
\hline \multirow{2}{*}{$\mathrm{pH}$} & Recuperação (\%) & \multicolumn{3}{c}{ Recuperação (\%) } & Recuperação (\%) \\
\cline { 2 - 6 } & $0,038-0,075 \mathrm{~mm}$ & $\mathrm{PH}$ & $0,01-0,038 \mathrm{~mm}$ & $\mathrm{PH}$ & $0-0,01 \mathrm{~mm}$ \\
\hline 1,9 & 5 & 2,3 & 11 & 2,3 & 17 \\
4 & 11 & 4,4 & 19 & 4,4 & 30 \\
6 & 18 & 6,4 & 28 & 6,2 & 43 \\
7,8 & 25 & 7,7 & 39 & 7,8 & 57 \\
9,2 & 25 & 9,1 & 35 & 9,1 & 49 \\
11 & 15 & 10,5 & 22 & 10,5 & 30 \\
12,6 & 6 & 12,2 & 12 & 12,2 & 19 \\
\hline
\end{tabular}

\subsubsection{SIPX - Isopropil xantato de sódio}

O artigo de número 7 fez um trabalho diferenciado, estudou a recuperação do mineral de caulinita junto com o mineral de ouro e de cobre. Na moagem ocorreu a adição de 8g/t de Cytec 3894a (tio carbamato). Nos testes de flotação estudou-se o arrastamento das partículas de caulinita em cobre e ouro com água do mar e em água doce. O coletor escolhido foi o SIPX (6 $\mathrm{g} / \mathrm{t})$ e foi adicionado um espumante não definido $(15 \mathrm{~g} / \mathrm{t})$.

A porcentagem de caulinita no minério é de $15 \mathrm{wt}$. Conforme a tabela 49 a recuperação de caulinita aumenta com a diminuição do tamanho das partículas tanto para água doce como para água salgada. 
Tabela 49: Resultados dos resultados de recuperação nos testes de flotação para o coletor SIPX em três faixas granulométricas para o artigo de número 7 (Elaboração própria)

Caulinita - Coletor SIPX

\begin{tabular}{ccc}
\hline $\begin{array}{c}\text { Tamanho de partícula } \\
(\mu \mathrm{m})\end{array}$ & $\begin{array}{c}\text { Recuperação com água do mar } \\
(\%)\end{array}$ & $\begin{array}{c}\text { Recuperação com água doce } \\
(\%)\end{array}$ \\
\hline${ }^{*} 0-11$ & 18,4 & 13 \\
${ }^{*}+11-16$ & 9 & 7 \\
${ }^{*}+16-24$ & 5 & 4 \\
${ }^{*}+24-35$ & 3 & 3 \\
${ }^{*}+35-46$ & 2 & 2 \\
$*+46-53$ & 2 & 2 \\
\hline
\end{tabular}

\subsubsection{HHO - Hidrolisado de lavagem suína}

O artigo de número 29 usou como agente coletor Hidrolisado de lavagem suína (Ácido oleico, 38,5\%, ácido linoleico, 32,8\%, ácido linolênico, 4,9\%, ácido esteárico, $8,5 \%$, ácido palmítico, $7,1 \%$, outros, $8,2 \%$ ) em uma concentração de $0,25 \mathrm{mmol} / \mathrm{L}$. Conforme os resultados apresentados pelos autores embora a recuperação seja baixa para o mineral de caulinita a recuperação aumenta conforme o pH se torna mais alcalino (tabela 50). 
Tabela 50: Resultados dos resultados de recuperação nos testes de flotação para o coletor HHO para o artigo de número 29 (Elaboração própria)

\begin{tabular}{cc}
\multicolumn{2}{c}{ Caulinita - Coletor HHO } \\
\hline $\mathrm{pH}$ & Recuperação (\%) \\
\hline${ }^{*} 2-5$ & 25 \\
7 & 28 \\
8,7 & 38 \\
10 & 35 \\
12 & 39 \\
\hline
\end{tabular}

3.15.29 BBAB - Gemini surfactante de trisiloxano butano-1,4-bis (dimetil- (3- (3aminopropil trisiloxano-3-il) -propil-etil) -amónio)

O artigo de número 26 trabalhou com o coletor BBAB. Conforme os autores em uma concentração $2.0 \times 10^{-4} \mathrm{~mol} / \mathrm{L}$ a flotabilidade do mineral de caulinita diminui com em pH mais alcalino, embora flota-se muito bem do pH 2 até 10 (Tabela 51).

Tabela 51: Resultados dos resultados de recuperação nos testes de flotação para o coletor BBAB para o artigo de número 26 (Elaboração própria)

Caulinita - Coletor BBAB

\begin{tabular}{cc}
\hline $\mathrm{pH}$ & Recuperação (\%) \\
\hline${ }^{*} 2-6,3$ & 98 \\
8,2 & 97 \\
10 & 96 \\
12 & 85 \\
\hline
\end{tabular}




\section{CONCLUSÃO}

Dentro do universo pesquisado, para o período de tempo de 1992 a 2015 no ScienceDirect os resultados obtidos demostraram que:

- $83 \%$ eram publicações chinesas (30 artigos), $8 \%$ australianos (3 artigos) seguindo-se Brasil, Estados Unidos e Alemanha com 1 artigo cada com uma contribuição de $3 \%$ por país. E três artigos elaborados por colaboração cientifica entre países que foram China e Canadá e China e Estados Unidos. Conclui-se que a produção científica brasileira em revistas de alto impacto, no que se refere a flotação de caulinita, ainda é muito baixa. Já os chineses, em termos de quantidade, sua participação em publicações de grande impacto tem sido significativa na área acadêmica.

- A flotação de caulinita em minérios bauxiticos, tem sido o alvo preferencial dos pesquisadores. De modo geral os artigos privilegiam o mineral de diásporo e não o mineral de caulinita. Esse fato é em virtude de que os chineses são os maiores produtores de alumínio no mundo, e a caulinita é rejeito no processo de flotação reversa do diásporo.

- Através da análise evolutiva temporal concluiu-se que a partir do ano de 2003 os estudos de flotação de caulinita aumentaram significantemente. O auge das publicações ocorreu nos anos de 2009 e 2010, com 12 publicações ao todo. Os resultados apresentados indicam que há uma forte tendência de mais estudos referentes a flotação de caulinita, já que é necessário estudo aperfeiçoando a técnica da flotação para minérios bauxiticos, onde a caulinita é o rejeito do processo, e assim diminuir gastos nos processos subsequentes do tratamento de minério.

- A análise do número de autores por artigo mostrou que existe uma tendência de colaboração científica entre pesquisadores de um mesmo país. Apenas um artigo foi escrito individualmente, o que evidencia dificuldade de se trabalhar com esta área de maneira individual, e sete foi o número máximo de autores por artigo encontrado no estudo. Todavia, é restrito o número de parcerias internacionais. 
- Com treze publicações em revistas importantes na área da mineração, o chinês Hu Yuehua é o pesquisador de destaque nos estudos de flotação de caulinita.

- Já na análise dos artigos de acordo com o número de páginas, as publicações tendem a ser apresentadas em artigos de poucas páginas, na faixa média de sete páginas por artigo. O maior artigo localizado foi de 12 páginas e o menor foi de 3 páginas.

- $\mathrm{Na}$ análise dos artigos por periódicos, o grande destaque foi a revista Minerals Engineering. Dos 39 artigos estudados nessa dissertação 22 artigos foram publicaram nesse periódico, o que equivale a $56 \%$ de todas as publicações referente a flotação de caulinita.

- Através da análise dos artigos por palavras-chaves observou-se que a média de palavra-chave por artigo é de 4,5. Sendo o mínimo 2 palavras por artigo e o máximo 8 palavras por artigo. Referente as palavras-chaves por minerais envolvidos nos estudos de flotação, os termos "Aluminossilicatos", "Minérios oxidados" e "Diásporo" foram os mais frequentes encontrados nos artigos. Apenas $39 \%$ das vezes a caulinita é citada nos artigos como palavra-chave. Outras palavras-chaves também foram frequentemente encontras: "Flotação", "Flotação por espuma" e "Adsorção".

- No estudo de minerais envolvidos na flotação de caulinita observou-se que em $31 \%$ dos artigos a caulinita é estudada somente com diásporo. Além do diásporo a caulinita também foi estudada junto com ilita, pirofilita, hematita, feldespato, ouro e cobre.

- As publicações concentram basicamente na quantificação de variáveis e optam por estudos experimentais. Além da flotação, os métodos mais significantes utilizados nos 39 artigos foram potencial zeta, métodos de caracterização mineralógica e estudos de adsorção.

- Levando em consideração as citações pelo Scopus, o estudo mais impactante dessa análise bibliométrica é o artigo "Role of crystal structure in flotation separation of diaspore from kaolinite, pyrophyllite and illite" dos 
autores $\mathrm{Y}$. Hu, X Liu e Zhenghe $\mathrm{Xu}$, com setenta e uma citações ao todo. No Brasil os autores encontrados com artigos no Science Direct foram: Otávia Martins Silva Rodrigues, Antônio Eduardo Clark Peres, Afonso Henriques Martins e Carlos Alberto Pereira.

- Dos reagentes utilizados nos testes de flotação de caulinita, $48 \%$ foram derivados de nitrogenados (catiônicos) sendo: 22\% sais de amônio quaternário, $5 \%$ amida, $9 \%$ amina terciária, $5 \%$ éter amina - éter monoamina - éter diamina e $7 \%$ sal de amina primária. Os ácidos carboxílicos embora apresentem uma baixa flotabilidade para o mineral de caulinita, representam $17 \%$ dos reagentes utilizado nos artigos.

- Referente ao pH de flotação dos reagentes utilizados nessa dissertação, observou-se a predominância de melhores desempenhos de flotação em meio ácido, embora a literatura reporte que os melhores desempenhos são em meio alcalino. É importante salientar que na grande parte dos estudos, os autores não descrevem se realidade da usina de tratamento de minérios de cada país condiz com os resultados obtidos em seus estudos (ensaios de flotação de caulinita em escala de bancada e com amostras puras). $\mathrm{O}$ artigo brasileiro "Kaolinite and hematite flotation separation using etheramine and ammonium quartenary salts" de autoria de $\mathrm{O} M \mathrm{~S}$ Rodrigues, A E C Peres, A H Martins e C A Pereira é um dos poucos que retrata a possível aplicação do estudo em uma usina de tratamento de minérios. Nesse último estudo, o melhor $\mathrm{pH}$ de flotação ocorre em meio alcalino.

- Muitos coletores utilizados na flotação da caulinita dos artigos são reagentes utilizados especificamente em escala laboratorial, ou seja, difícil de produzir (sintetizar) e possivelmente difícil de produzir em escala industrial.

- Os resultados de recuperações na flotação mostraram que diversos coletores apresentam ótimas recuperações para caulinita em uma ampla faixa de $\mathrm{pH}$, exemplos: BBAB e 12-4-12. Os coletores mais representativos em meio alcalino foram: Flotigam EDA e AQ142. Já com significativas recuperações em meio ácido e baixas recuperações em meio básico se 
destacam os coletores: DDA (artigo 30), DDA mais APAM (artigo 11), DRN, DEN, DPN e DBN.

- Os artigos estudados nessa dissertação mostram que a caulinita é um problema crítico principalmente nos minérios bauxiticos, e que os estudos envolvendo a caulinita e o diásporo vem sendo aperfeiçoados ano após ano. Já no Brasil a caulinita também está presente na ganga do minério de ferro e estudos como dos pesquisadores Rodrigues et al enfatizam a importância do estudo da flotação de caulinita para os minérios brasileiros.

- Observou-se também trabalhos semelhantes, e muitos artigos são continuação de um mesmo estudo publicado anteriormente.

- O presente trabalho buscou trazer informações atuais referente à flotação da caulinita na presença de tensoativos. No entanto, novos estudos devem ser elaborados, principalmente no que diz respeito aos aspectos antagônicos entre a literatura clássica sobre flotação de silicatos e os resultados discutidos nessa dissertação. 


\section{Sugestões para trabalhos futuros}

Explorar outras bases de dados como, por exemplo, Scientific Electronic Library Online (SciELO), além de estender a pesquisa para dissertações de mestrado e teses de doutorado que são fontes seguras de consulta devido o rigor na sua elaboração. Outra sugestão é ampliar a fronteira temporal para uma nova análise bibliométrica sobre flotação de caulinita, e transformar o estudo em uma análise epistemológica. 


\section{REFERÊNCIAS}

ARAÚJO, C.A. Bibliometria: evolução histórica e questões atuais. Em Questão, Porto Alegre, v. 12, n. 1, p. 11-32, jan./jun. 2006.

BERGAYA, F.; THENG, B.K.G;LAGALY,G. Handbook of Clay Science. Ed 1. Developments in Clay Science, 1-1224p. 2006.

BNDES. A indústria do alumínio: estrutura e tendências. Insumos Básicos Setorial 33, p. 43-88. Sem data.

CALLISTER, W.D; RETHWISCH, D. G. Materials Science and Engineering. Ed 9. 2004.

CHAGAS, A. P. Argilas as essências da terra. Universidade Estadual de Campinas. Editora Moderna, sem data.

CHAVES, A.P. Teoria e Prática do Tratamento de Minérios, A Flotação no Brasil. São Paulo: Editora Signus. Vol.4. PP.199-217 (2009).

CHEN, P.Y; LIN, M. L; ZHENG, Z. On the Original of the name Kaolin deposits of the Kauling and Dazhou áreas, Kiangsi, China. Applied Clay Science, v. 12. 1997. 
COELHO, A. C. V; SANTOS H. S. Argilas especiais: o que são, caracterização e propriedades. Quim. Nova, Vol. 30, No. 1, 146-152, 2007.

CONSTANTINO, V. L. Preparação de compostos de alumínio a partir da bauxita: considerações sobre alguns aspectos envolvidos em um experimento didático. Química Nova. v. 25, p. 490-498, 2002.

DANA, J. D; HURLBUT, C.S. Manual de Mineralogia. Livros Técnicos e Científicos. S.A. volume , 642p. Rio de Janeiro, 1974.

DI LIU; YONGJUN PENG. Reducing the entrainment of clay minerals in flotation using tap and saline water. Vol 253, 2014.

ELSEVIER BASE DE DADO. Disponível em: ww.americalatina.elsevier.com/sul/ptbr/revisores.pHp. Acesso em: 16 de julho de 2015.

FORTUNA, J; BIASI, L.H; MARQUES, A.J; MARTINS, J.C; DOMINGUINI, L. Processo Bayer de obtenção de alumina como ferramenta para o ensino de conceitos de estequiometria. XVI Encontro Nacional de Ensino de Química (XVI ENEQ) e X Encontro de Educação Química da Bahia (X EDUQUI) Salvador, BA, Brasil 17 a 20 de julho de 2012.

FUERSTENAU, D.W. (1957) Correlation of contact angles, adsorption density, zeta potentials and flotation rate. Trans. AIME, 208, pp. 1365-1367. 
FUERSTENAU, D.W.; HEALY, T.W.; SOMASUNDARAN, P. (1964) The role of hydrocarbon chain of alkyl collectors in flotation. Trans. AIME 229, pp. 321-325.

FUERSTENAU, D.W.; YAMADA, B. J. (1962) Minerals beneficiation - neutral molecules in flotation collection. Trans. AIME, 223, pp. 50-52.

GAUDIN, A.M.; FUERSTENAU, D.W. (1955) Quartz flotation with cationic collectors. Trans. AIME, 202, pp. 958-962.

GOMES, C.F. Argilas O que são e para que servem. Fundação Calouste Gulbenkianl. V 1. 1988.

GUAN FENG; ZHONG HONG; LIU GUANG-YI; ZHAO SHENG-GUI; XIA LIU-YIN. Flotation of aluminosilicate minerals using alkylguanidine. Trans, Nonferrous Met. Soc. China. Vol 19, 2009.

GUANGYI LIU; HONG ZHONG; YUEHUA HU; SHENGGUI ZHAO; LIUYIN XIA. The role of cationic polyacrylamide in the reverse flotation of diasporic bauxite. Minerals Engineering, Vol 20, 2007.

GUEDES, V.L.S; BORSCHIVER, S. Bibliometria: uma ferramenta estatística para a gestão da informação e do conhecimento, em sistemas de informação, de comunicação e de avaliação científica e tecnológica. Sem data. 
GUO J. A novel depressor useful for flotation separation of diaspore and kaolinite. Mining Science and Technology. Vol 20, 2010.

HAIPU LI; SHASHA ZHANG; HAO JIANG; YUEHUA HU; DIANZUO WANG. Selective depression of diaspore with waxy maize starch. Minerals Engineering, vol 23, 2010.

Hu, Y., Wei, S., Hao, J., Miller, J.D., Fa, K., The anomalous behavior of kaolinite flotation with dodecyl amine collector as explained from crystal structure considerations. Int. J. Miner. Process. 76 (3), 163-172, 2005.

$\mathrm{HU}, \mathrm{Y} ;$ JIANG, H; WANG, D. Electrokinetic behavior and flotation of kaolinite in CTAB solution. Minerals Engineering,n.16. 1221-1223, 2003.

HU, Y; LIU, X. Chemical composition and surface property of kaolins. Minerals Engineering,n.16. 1279-1284,2003.

$\mathrm{HU}, \mathrm{Y} ; \mathrm{LIU}, \mathrm{X} ; \mathrm{XU}, \mathrm{Z}$. Role of crystal structure in flotation separation of diaspore from kaolinite, pyropHyllite and illite. Minerals Engineering, n.16, 219-227, 2003.

HUANG Z; ZHONG H; WANG S; XIA L; LIU G. Comparative studies on flotation of aluminosilicate minerals with Gemini cationic surfactants BDDA and EDDA. Trans. Nonferrous Met. Soc. China, Vol 23,2013. 
JIANG HAO; LIU GUORONG; HU YUEHUA; XU LONGHUA; YU YAWEN; XIE ZHEN; CHEN HAOCHUAN. Flotation and adsorption of quaternary ammonium salts collectors on kaolinite of different particle size. International Journal of Mining Science and Technology. Vol 23, 2013.

JIANG YU-REN; YIN ZHI-GANG; YI YUN-LA; ZHOU XIAO-HONG. Synthesis and collecting properties of novel carboxyl hydroxamic acids for diaspore and aluminosilicate minerals. Minerals Engineering, Vol 23,2010.

JIANG, H; HU Y; QIN, W; QIU, G. Interaction and flotation of diaspore with alkylamine hydrochlorides. Trans Nonferrous Met Soc China, p 430-433. China. 2001.

JIANG, H; SUN, Z; XU, L; HU,Y; HUANG, K; ZHU,S. A comparison study of the flotation and adsorption behaviors of diaspore and kaolinite with quaternary ammonium collectors. Minerals Engineering,n.65. 124-128,2014.

JIANG, H; XU, L; HU, Y; WANG, D; LI, C; MENG, W; WANG X. Flotation and adsorption of quaternary ammonium cationic collectors on diaspore and kaolinite. Transactions of Nonferrous Met. Soc. China n.21. 2528-2534, 2011.

JING LIU; XUMING WANG; CHEN-LUH LIN; JAN D. MILLER. Significance of particle aggregation in the reverse flotation of kaolinite from bauxite ore. Minerals Engineering, Vol 78. 2015. 
KÖSTER, R; SCHRECK, B; RYBINSKIL V; DOBIAS, B. New reagent systems for the flotation of kaolinite. Minerals Enginnering, v.5, p 445-456, 1992.

LANQING DENGA; SHUAI WANGA; HONG ZHONGA; GUANGYI LIUA. N-(6(hydroxyamino)-6-oxohexyl) decanamide collector: Flotationperformance and adsorption mechanism to diaspore. Applied Surface Science, Vol 324, 2015.

LEAL, P.V.B; MAGRIOTI, Z.M; SALES, P.F; PAPINI, R.M. Estudo da adsorção de eteramina em caulinita rosa. Sociedade Brasileira de Química ( SBQ), 2009.

LEAL, P.V.B; MAGRIOTI, Z.M; SALES, P.F; PAPINI, R.M. influência do pH na cinética de adsorção de aminas em caulinita branca. XVII congresso de pós-graduação da UFLA, I encontro de engenharia de sistemas, IV workshop de laser e óptica na agricultura, 2008.

LEJA, J. (1982) Surface chemistry of froth flotation. Plenum Press, New York, 758pp.

LIU C; FENG A; GUO Z; CAO X; HU Y. Dynamics simulation of tertiary amines adsorbing on kaolinite (001) plane. Trans. Nonferrous Met. Soc. China. Vol 21, 2011.

LIU, C; ANSHENG, F; ZHENXUM, G; XUEFENG, C; YUEHUA, H. Flotation behavior of four dodecyl tertiary amines as collectors of diaspore and kaolinite. Mining Science and Technology (China), n.21,2011. 
LIU, C; HU, Y; FENG,A; GUO, Z; CAO, X. The behavior of N,N-dipropyl dodecyl amine as a collector in the flotation of kaolinite and diaspore. Minerals Engineering, n.24, 737-740, 2011.

LIU, X; HU, Y; CAO, X. Substituent effects in kaolinite flotation using dodecyl tertiary amines. Minerals Engineering,n.22. 849-852, 2009.

LIUYIN XIA; HONG ZHONG; GUANGYI LIU; ZHIQIANG HUANG; QINGWEI CHANG. Flotation separation of the aluminosilicates from diaspore by a Gemini cationic collector. Int. J. Miner. Process. Vol 92, 2009.

LIUYIN, X; HONG, Z; GUANGYI, L; SHUAI, W. Utilization of soluble starch as a depressant for the reverse flotation of diaspore from kaolinite. Minerals Engineering, n.22, 560-565, 2009.

LUZ, A.B; DAMASCO, E. C. Caulim: Um mineral Industrial Importante. CETEM/CNPQ, Rio de Janeito, 29p. 1993.

LUZ, A.B; SAMPAIO, A.J; FRANÇA, S.C.A. Tratamento de minérios. $5^{\circ}$ edição, 888p, CETEM, Rio de Janeiro, 2010.

MA, X; BRUCKARD, W.J. HOLMES, R. Effect of Collector, Ph AND Ionic Strength on the CATIONIC Flotation of Kaolinite. International Journal Mineral Processing. P 54-58. 2009 
MA, X; BRUCKARD, W.J; HOLMES, R. Effect of collector, pH and ionic strength on the cationic flotation of kaolinite. Int. J. Miner. Process, n.93, 54-58,2009.

MELLO, S.M. et al. Revisão sobre argilominerais e suas modificações estruturais com ênfase em aplicações tecnológicas e adsorção - uma pesquisa inovadora em universidades. Revista de Ciências Agro-Ambientais, Alta Floresta, v.9, n.1, p.141-152, 2011.

MILLER, J.D.; KHALEK, A.; BASILIO, C.; EL-SHALL, H.; FA, K.; FORSSBERG, K.S.E.; FUERSTENAU, M.C.; MATHUR, S.; NALASKOWSKI, J.; RAO, K.H.; SOMASUNDARAN, P. WANG, X.; ZHANG, P. (2007) Flotation chemistry and technology of nonsulfide minerals. In: FUERSTENAU,M.C,; JAMESON, G.; YOON, R.H. Froth flotation - A century of innovation. SME, Littleton, p 465-553.

MING ZHANG; NING XU; YONGJUN PENG. The entrainment of kaolinite particles in copper and gold flotation using fresh water and sea water. Powder Technology. Vol 286,2015.

MURRAY, H. H. Traditional and new applications for kaolin, smectite and palygorskite: a general overview. Applied Clay Science.207-221. 2000.7

NEDER, E. E: LEAL, L S. O USO DE AMINAS GRAXAS E SEUS DERIVADOS NA FLOTAÇÃO DE MINÉRIOS BRASILEIROS. Holos, Ano 22, maio 2006 
NEDER, E.E. O uso de aminas graxas e seus derivados na flotação de minérios brasileiros. Dissertação de mestrado. Universidade de São Paulo, São Paulo, 91pp. 2005.

RODRIGUES, O.M.S. Estudos de Flotação de Caulinita. Dissertação de mestrado, pp 95, UFMG,. 2009.

RODRIGUES, O.M.S; ARAUJO, A. C; PERES, A.E.C. Kaolinite microflotation and electrokinetic properties. Minerals \& Metallurgical Processing, vol.28, 2011.

RODRIGUES, O.M.S; ARAUJO, A. C; PERES, A.E.C. Microflotação de caulinita utilizando aminas. REM, n.4, 661-666, 2010.

RODRIGUES, O.M.S; PERES, A.E.C; MARTINS, A.H. Kaolinite and hematite flotation separation using etheramine and ammonium quaternary salts. Minerals Engineering,n.40. 12-15,2013.

S.M. ZHAO; D.Z. WANG; Y.H. HU; S.X. BAO; J. XU. Flotation of aluminosilicates using N-(2-aminoethyl)-1-naphthaleneacetamide. Minerals Engineering. Vol 16, 2003.

SANTOS, P.S.; SANTOS, H.S. Ciência e tecnologia de argilas. 2. São Paulo.3v. 19891992, 1089p. 
SILVA, M. E. O caulim do Rio Capim. Dissertação de mestrado, Universidade Candido Mendes. 113 p. Rio de Janeiro. 2003

SMITH, W.R.; AKHTAR, S. (1976) Cationic flotation of oxides and silicates. In: FUERSTENAU, M. C., Flotation - A. M. Gaudin Memorial Volume. American Institute of Mining, Metallurgical and Petroleum Engineers, inc, New York, pp. 87-116.

SOMASUNDARAN, P.; ZHANG, L.; HEALY, T.W.; DUCKER, W.; HERRERAURBINA, R.; FUERSTENAU, M.C. (2007) Adsorption of surfactants and its influence on the hydrodynamics of flotation. In: FUERSTENAU, M.C.; JAMESON, G. and YOON, R. Froth flotation - A century of innovation. SME, Littleton, pp. 179-225.

VIANNA, C.F. Discussão epistemológica da produção de científica brasileira em biodiesel. Tese de Doutorado. Universidade de São Paulo, São Paulo, pp. 120. 2012.

VIDYADHAR, A.; RAO, H.K.; CHERNYSHOVA, I.V.; PRADIP,K.S.; FORSBERG, E. (2002) Mechanisms of amine-quartz interaction in the absence and presence of alcohols studied by spectroscopic methods. J. of colloid and interface science, 256, pp. 59-72. 
WEI, S; KUI, O; LIMIN, Z; YUEHUA, H; CHEN, C. Preparation of hydrolyzate of hogwash oil $(\mathrm{HHO})$ and its application in separating diaspore from kaolinite. Minerals Engineering, Vol 2, 2010.

XAVIER, C.L. Alumínio; Economia de baixo carbono: Avaliação de impactos de restrições e perspectivas tecnológiacas. EBC. Relatório. Riberão preto, SP. Abril, 2012.

XIA LIU-YIN; ZHONG HONG; LIU GUANG-YI. Flotation techniques for separation of diaspore from bauxite using Gemini collector and starch depressant. Trans. Nonferrous Met. Soc. China. Vol 20, 2010.

XIA LIU-YIN; ZHONG HONG;LIU GUANG-YI; HUANG ZHI-QIANG; CHANG QINGWEI; LI XIN-GANG; Comparative studies on flotation of illite, pyrophyllite and kaolinite with Gemini and conventional cationic surfactants. Trans, Nonferrous Met. Soc. China. Vol 19, 2009.

XU, L; HU, Y; DONG, F; GAO, Z; WU, H; WANG, Z. Anisotropic adsorption of oleate on diaspore and kaolinite crystals:Implications for their flotation separation. Applied Surface Science, n.321. 331-338,2014.

YUEHUA H; WEI, S; HAIPU, L; XU, Z. Role of macromolecules in kaolinite flotation. Minerals Engineering,n.17. 1017-1022, 2004. 
YUEHUA HU; PAN CHEN; WEI SUN. Study on quantitative structure-activity relationship of quaternary ammonium salt collectors for bauxite reverse flotation. Minerals Engineering, Vol 26, 2012.

YUEHUA, H; WEI, S; HAO,J; MILLER, J.D; FA, K. The anomalous behavior of kaolinite flotation with dodecyl amine collector as explained from crystal structure considerations. Int. J. Miner. Process, n. 76, 163-172, 2005.

YU-REN JIANG; BIN-NAN ZHAO; XIAO-HONG ZHOG; LI-YI ZHOU. Flotation of diaspore and aluminosilicate minerals applying novel carboxyl hydroxamic acids as collector. Hydrometallurgy. Vol 104, 2010.

YU-REN JIANG; WEI LI; RUI FENG. Preparation and performance of 4-alkyl-4,4bis(hydroxycarbamoyl) carboxylic acid for flotation separation of diaspore against aluminosilicates. Minerals Engineering. Vol 24, 2011.

YU-REN JIANG; XIN-XIN LI; RUI FENG; DAN CHEN; JUN-CHUAN LI. Novel alkyl bis(hydroxycarbamoyl) propionic acids for flotation separation of diaspore against aluminosilicate minerals. Vol 87, 2012.

ZHANG, L.M; CHEN, X.Q; LIU X. Review of flotation desilication on diasporic bauxite. International Mineral Processing Congress.p 1485-1490. Beijing -China. 
ZHAO, S.M; WANG, D.Z; HU, Y.H; LIU, B.D; XU, J. The flotation behaviour of N-(3aminopropyl)-dodecanamide on three aluminosilicates. Minerals Engineering, n.16, 1391-1395, 2003.

ZHIQIANG, H; HONG, Z; SHUAI, W; LIUYIN, X; GANG, Z; GUANGYI, L. Gemini trisiloxane surfactant: Synthesis and flotation of aluminosilicate minerals. Minerals Engineering, Vol 56, 2014.

ZHONG, H; LIU,G; XIA, L; LU, Y; HU, Y; ZHAO, S; YU, X. Flotation separation of diaspore from kaolinite, pyropHyllite and illite using three cationic collectors. Minerals \& Metallurgical Processing, vol.21, 2008. 


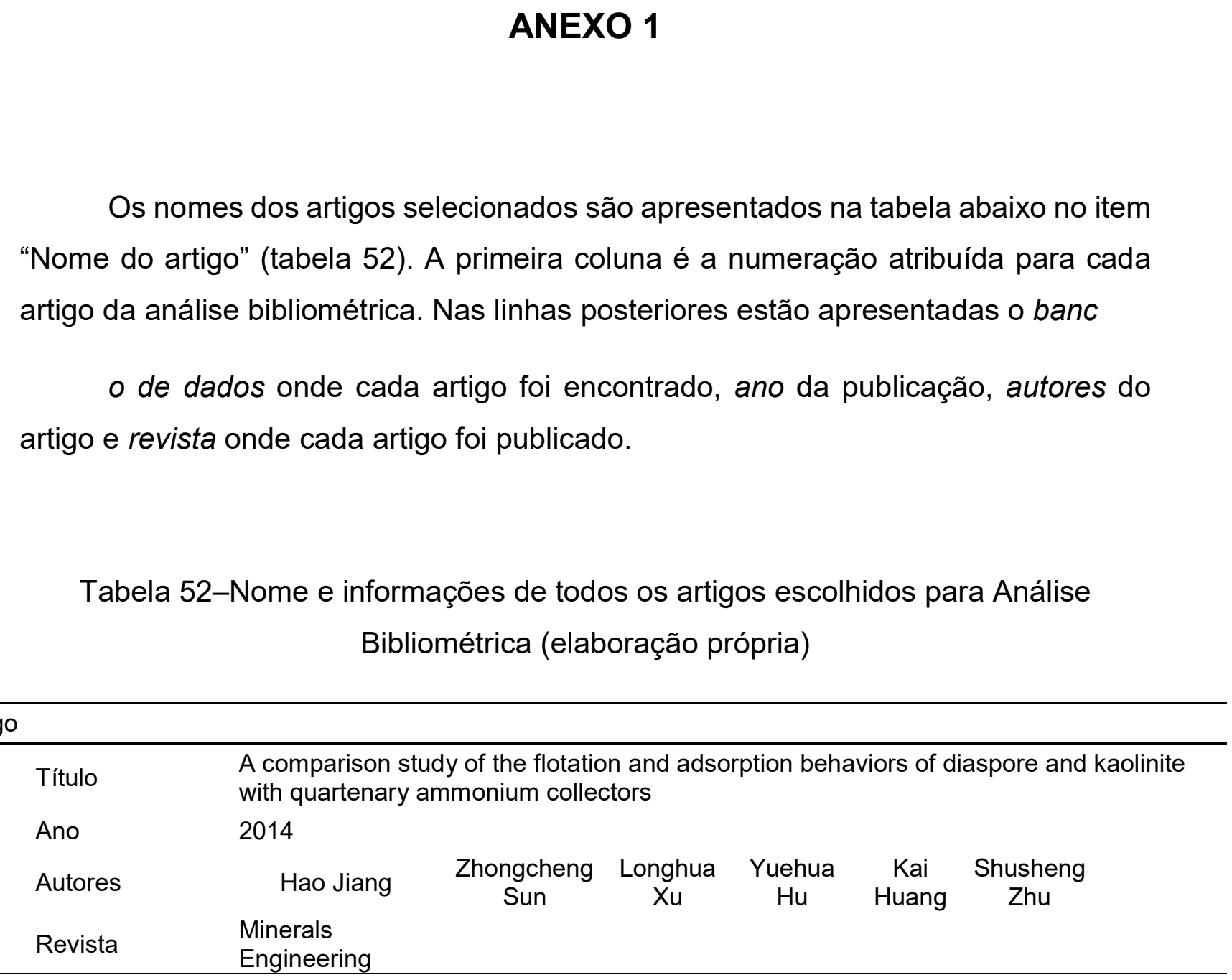

\begin{tabular}{|c|c|c|c|c|}
\hline \multicolumn{5}{|c|}{ Artigo } \\
\hline \multirow{4}{*}{2} & Título & $\begin{array}{l}\text { Kaolinite and hematite flotation s } \\
\text { salts }\end{array}$ & paration & ing etheramine and ammonium quartenary \\
\hline & Ano & 2012 & & \\
\hline & Autores & O M S Rodrigues A E C Peres & $\underset{\text { Martins }}{\mathrm{A} \mathrm{H}}$ & $\begin{array}{c}\text { C A } \\
\text { Pereira }\end{array}$ \\
\hline & Revista & $\begin{array}{l}\text { Minerals } \\
\text { Engineering }\end{array}$ & & \\
\hline
\end{tabular}




\begin{tabular}{|c|c|c|c|c|c|c|}
\hline \multicolumn{7}{|c|}{ Artigo } \\
\hline \multirow{4}{*}{3} & Nome do artigo & $\begin{array}{l}\text { Flotation and adsorption of quart } \\
\text { kaolinite }\end{array}$ & rnary amn & onium catio & ic colle & rs on diaspore and \\
\hline & Ano & 2011 & & & & \\
\hline & Autores & Longhua Xu & $\begin{array}{l}\text { Wang } \\
\text { dian zuo }\end{array}$ & $\begin{array}{l}\text { Li Chang- } \\
\text { kai }\end{array}$ & $\begin{array}{l}\text { Meng } \\
\text { Wei }\end{array}$ & $\begin{array}{l}\text { Wang } \\
\text { Xing-jie }\end{array}$ \\
\hline & Revista & Transaction of Nonferrous Metals & Society of & China & & \\
\hline
\end{tabular}

\begin{tabular}{|c|c|c|c|c|c|c|}
\hline \multicolumn{7}{|c|}{ Artigo } \\
\hline \multirow{4}{*}{4} & Título & Flotation behavio & four dodec & ertiary al & ines as co & ectors of diaspore and kaolinite \\
\hline & Ano & 2010 & & & & \\
\hline & Autores & Changmiao Liu & $\begin{array}{c}\text { Feng } \\
\text { Ansheng }\end{array}$ & $\begin{array}{c}\text { Guo } \\
\text { Zhenxu }\end{array}$ & $\begin{array}{c}\text { Cao } \\
\text { Xuefeng }\end{array}$ & $\begin{array}{c}\text { Hu } \\
\text { Yuehua }\end{array}$ \\
\hline & Revista & Mining Science a & Technology & & & \\
\hline
\end{tabular}

\begin{tabular}{|c|c|c|c|c|c|c|}
\hline Artig & & & & & & \\
\hline & Título & Selective dep & of diaspo & th wax & aize starc & \\
\hline & Ano & 2010 & & & & \\
\hline 5 & Autores & Haipu Li & $\begin{array}{l}\text { Shasha } \\
\text { Zhang }\end{array}$ & $\begin{array}{l}\text { Hao } \\
\text { Jiang }\end{array}$ & $\begin{array}{c}\text { Yuehua } \\
\text { Hub }\end{array}$ & $\begin{array}{c}\text { Dianzuo } \\
\text { Wang }\end{array}$ \\
\hline & Revista & Minerals Engi & & & & \\
\hline
\end{tabular}

\begin{tabular}{|c|c|c|c|}
\hline Artig & & & \\
\hline & Título & Electrokinec behavior and flot & n of kaolinite in CTAB solution \\
\hline 6 & Ano & 2003 & \\
\hline 0 & Autores & H. Jing & D. Wang \\
\hline & Revista & Minerals Engineering & \\
\hline
\end{tabular}

\begin{tabular}{|c|c|c|c|c|}
\hline \multicolumn{5}{|c|}{ Artigo } \\
\hline \multirow{4}{*}{7} & Título & $\begin{array}{l}\text { The entrainmen } \\
\text { sea water }\end{array}$ & aolinite pa & les in copper and gold flotation using fresh water and \\
\hline & Ano & 2015 & \multirow{3}{*}{ Ning $X u$} & \multirow{3}{*}{$\begin{array}{l}\text { Yongjun } \\
\text { Peng }\end{array}$} \\
\hline & Autores & Ming Zhang & & \\
\hline & Revista & Powder Techno & & \\
\hline
\end{tabular}




\begin{tabular}{|c|c|c|}
\hline Artig & & \\
\hline & Título & Chemical composition and surface property of kaolins \\
\hline 0 & Ano & 2003 \\
\hline 0 & Autores & X. Liu \\
\hline & Revista & Minerals Engineering \\
\hline
\end{tabular}

\begin{tabular}{|c|c|c|c|c|c|c|c|}
\hline \multicolumn{8}{|c|}{ Artigo } \\
\hline \multirow{4}{*}{9} & Título & $\begin{array}{l}\text { Anisotropic ads } \\
\text { flotation separa }\end{array}$ & on of oleate & diaspo & and kaolir & crystals & plications for their \\
\hline & Ano & 2014 & & & & & \\
\hline & Autores & Longhua Xu & Yuehua Hu & $\begin{array}{l}\text { Faqin } \\
\text { Dong }\end{array}$ & $\begin{array}{c}\text { Zhiyong } \\
\text { Gao }\end{array}$ & $\begin{array}{l}\text { Houqin } \\
\text { Wu }\end{array}$ & $\begin{array}{l}\text { Zhen } \\
\text { Wang }\end{array}$ \\
\hline & Revista & Applied Surface & ence & & & & \\
\hline
\end{tabular}

\begin{tabular}{|c|c|c|c|}
\hline \multicolumn{4}{|c|}{ Artigo } \\
\hline \multirow{4}{*}{10} & Título & Effect of collector, $\mathrm{pH}$ and ionic & ength on the cationic flotation of kaolinite \\
\hline & Ano & 2009 & \\
\hline & Autores & $\begin{array}{c}\text { W.J. } \\
\text { Bruckard }\end{array}$ & $\begin{array}{c}\text { R. } \\
\text { Holmes }\end{array}$ \\
\hline & Revista & In. Jr. Mineral Processing & \\
\hline
\end{tabular}

\begin{tabular}{|c|c|c|c|c|}
\hline Artigo & & & & \\
\hline & Título & Role of macromolecules in kac & te flotation & \\
\hline & Ano & 2004 & & \\
\hline 11 & Autores & Hu Yuehua & Li Haipu & $\begin{array}{c}\text { Zhenghe } \\
\text { Xu }\end{array}$ \\
\hline & Revista & Minerals Engineering & & \\
\hline
\end{tabular}

\begin{tabular}{|c|c|c|c|}
\hline Artig & & & \\
\hline & Título & Substituent effects in kaolinite flc & ation using dodecyl tertiary amines \\
\hline & Ano & 2009 & \\
\hline 12 & Autores & Changmiao Liu & $\begin{array}{c}\text { Xuefeng } \\
\text { Cao }\end{array}$ \\
\hline & Revista & Minerals Engineering & \\
\hline
\end{tabular}




\begin{tabular}{|c|c|c|c|c|c|c|}
\hline \multicolumn{7}{|c|}{ Artigo } \\
\hline \multirow{4}{*}{13} & Título & $\begin{array}{l}\text { The anomalous } \\
\text { from crystal stru }\end{array}$ & $\begin{array}{l}\text { vior of kac } \\
\text { considera }\end{array}$ & $\begin{array}{l}\text { e flotati } \\
\text { s }\end{array}$ & with dodec & yl amine collector as explained \\
\hline & Ano & 2005 & & & & \\
\hline & Autores & Hu Yuehua & Sun Wei & $\begin{array}{l}\text { Jiang } \\
\text { Hao }\end{array}$ & J.D Miller & $\begin{array}{l}\text { Keqing } \\
\mathrm{Fa}\end{array}$ \\
\hline & Revista & Mineral Proces & & & & \\
\hline
\end{tabular}

\begin{tabular}{|c|c|c|c|c|}
\hline \multicolumn{5}{|l|}{ Artigo } \\
\hline \multirow{4}{*}{14} & Nome do artigo & $\begin{array}{l}\text { Utilization of soluble starch as a } \\
\text { kaolinite }\end{array}$ & epressant & the reverse flotation of diaspore from \\
\hline & Ano & 2009 & & \\
\hline & Autores & Zhong Hong & $\begin{array}{l}\text { Liu } \\
\text { Guangyi }\end{array}$ & $\begin{array}{l}\text { Wang } \\
\text { Shuai }\end{array}$ \\
\hline & Revista & Minerals Engineering & & \\
\hline
\end{tabular}

\section{Artigo INFORMAÇÕES}

\begin{tabular}{|c|c|c|c|c|}
\hline \multirow{4}{*}{15} & Título & \multicolumn{3}{|c|}{ r of N,N-dipropyl dodecyl amine as } \\
\hline & Ano & 2011 & & \\
\hline & Autores & Changmiao Liu & $\begin{array}{l}\text { Zhenxu } \\
\text { Guo }\end{array}$ & $\begin{array}{c}\text { Xuefeng } \\
\text { Cao }\end{array}$ \\
\hline & Revista & Minerals Engeering & & \\
\hline
\end{tabular}

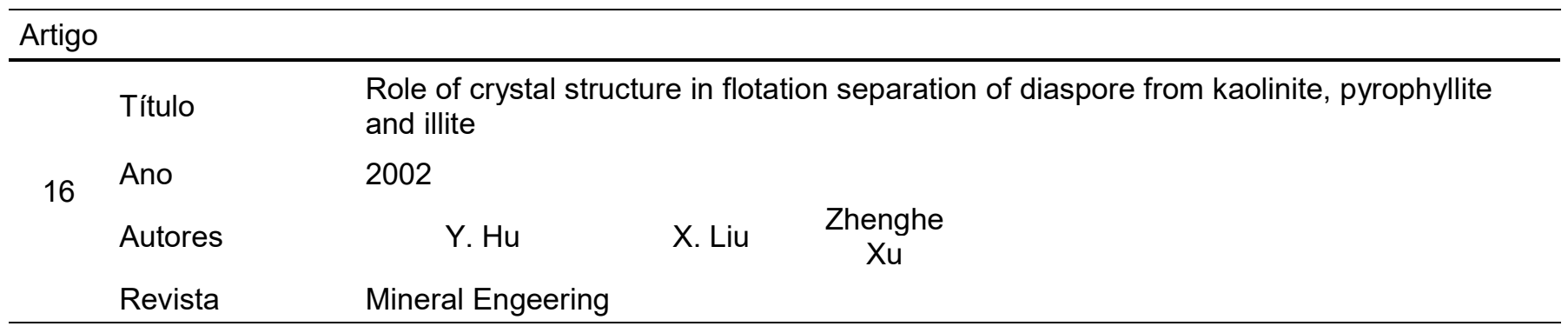

\section{Artigo}




\begin{tabular}{|c|c|c|c|c|c|c|}
\hline \multirow{4}{*}{17} & Título & \multicolumn{5}{|c|}{ New Reagent systems for the Flotation ok Kaolinite } \\
\hline & Ano & \multicolumn{5}{|l|}{1992} \\
\hline & Autores & R. Koster & \multirow{2}{*}{$\begin{array}{l}\text { B. Schreck } \\
\text { g }\end{array}$} & \multirow[t]{2}{*}{$\begin{array}{l}\text { W.von } \\
\text { Rybinski }\end{array}$} & \multirow{2}{*}{\multicolumn{2}{|c|}{ B. Dobiás }} \\
\hline & Revista & Minerals Engineering & & & & \\
\hline \multicolumn{7}{|c|}{ Artigo } \\
\hline \multirow{4}{*}{18} & Título & \multicolumn{5}{|c|}{ The flotation behaviour of $\mathrm{N}$-(3-aminopropyl)-dodecanamide on three aluminosilicates } \\
\hline & Ano & \multicolumn{5}{|l|}{2003} \\
\hline & Autores & S.M. Zhao & D.Z. Wang & Y.H. Hu & B.D. Liu & J. Xu \\
\hline & Revista & \multicolumn{5}{|c|}{ Minerals Engineering } \\
\hline
\end{tabular}

\begin{tabular}{|c|c|c|c|c|c|c|c|}
\hline \multicolumn{8}{|c|}{ Artigo } \\
\hline \multirow{4}{*}{19} & Título & $\begin{array}{l}\text { Comparative st } \\
\text { conventional ca }\end{array}$ & $\begin{array}{l}\text { on flotatio } \\
\text { surfactan }\end{array}$ & fillite, pyrc & phyllite anc & kaolinite & th Gemini and \\
\hline & Ano & 2009 & & & & & \\
\hline & Autores & XIA Liu-yin & $\begin{array}{c}\text { ZHONG } \\
\text { Hong }\end{array}$ & $\begin{array}{l}\text { LIU } \\
\text { Guang-yi }\end{array}$ & $\begin{array}{l}\text { HUANG } \\
\text { Zhi-qiang }\end{array}$ & $\begin{array}{c}\text { CHANG } \\
\text { Qing- } \\
\text { wei }\end{array}$ & $\begin{array}{l}\text { LI Xin- } \\
\text { gang }\end{array}$ \\
\hline & Revista & \multicolumn{6}{|c|}{ Transaction of Nonferrous Metals Society of China } \\
\hline
\end{tabular}

\section{Artigo}

\begin{tabular}{|c|c|c|c|c|c|c|}
\hline \multirow{4}{*}{20} & Título & \multicolumn{5}{|c|}{ Flotation of aluminosilicate minerals using alkylguanidine collectors } \\
\hline & Ano & 2009 & & & & \\
\hline & Autores & GUAN Feng & $\begin{array}{c}\text { ZHONG } \\
\text { Hong }\end{array}$ & $\begin{array}{l}\text { LIU } \\
\text { Guang-yi }\end{array}$ & $\begin{array}{c}\text { ZHAO } \\
\text { Sheng- } \\
\text { gui }\end{array}$ & $\begin{array}{l}\text { XIA Liu- } \\
\text { yin }\end{array}$ \\
\hline & Revista & \multicolumn{5}{|c|}{ Transaction of Nonferrous Metals Society of China } \\
\hline
\end{tabular}

\begin{tabular}{|c|c|c|c|c|c|}
\hline \multicolumn{6}{|c|}{ Artigo } \\
\hline \multirow{4}{*}{21} & Nome do artigo & Flotation of aluminosilicates usin & $\mathrm{N}$-(2-amir & ethyl)-1-r & phthaleneacetamide \\
\hline & Ano & 2003 & & & \\
\hline & Autores & S.M. Zhao & Y.H. Hu & S.X. Bao & J. Xu \\
\hline & Revista & Minerals Engineering & & & \\
\hline
\end{tabular}

\section{Artigo}

22 Título

Flotation of diaspore and aluminosilicate minerals applying novel carboxyl hydroxamic acids as collector 
Ano

2010

Autores

Yu-Ren Jiang

$\begin{array}{cc}\text { Bin-Nan } & \text { Xiao- } \\ \text { Zhao } & \text { Hong } \\ & \text { Zhou }\end{array}$

$\mathrm{Li}-\mathrm{Yi}$

Revista

Hydrometallurgy

\begin{tabular}{|c|c|c|c|c|c|c|c|c|}
\hline \multicolumn{9}{|c|}{ Artigo } \\
\hline \multirow{4}{*}{23} & Título & $\begin{array}{l}\text { Flotation separa } \\
\text { collectors }\end{array}$ & of diaspore $f$ & n kaolir & e, pyrophyl & ite and illit & e using thre & cationic \\
\hline & Ano & 2008 & & & & & & \\
\hline & Autores & Hong Zhong & Guangyi Liu & $\begin{array}{l}\text { Liuyin } \\
\text { Xia }\end{array}$ & Yiping Lu & $\begin{array}{c}\text { Yuehua } \\
\text { Hu }\end{array}$ & $\begin{array}{l}\text { Shenggui } \\
\text { Zhao }\end{array}$ & $\begin{array}{c}\text { Xinyang } \\
\text { Yu }\end{array}$ \\
\hline & Revista & \multicolumn{7}{|c|}{ Minerals Engineering } \\
\hline
\end{tabular}

Artigo INFORMAÇÕES

\begin{tabular}{|c|c|c|c|c|c|}
\hline \multirow{4}{*}{24} & Título & \multicolumn{4}{|c|}{ Flotation separation of the aluminosilicates from diaspore by a Gemini cationic collector } \\
\hline & Ano & 2009 & & & \\
\hline & Autores & Hong Zhong & $\begin{array}{c}\text { Guangyi } \\
\text { Liu }\end{array}$ & $\begin{array}{c}\text { Zhiqiang } \\
\text { Huang }\end{array}$ & $\begin{array}{l}\text { Qingwei } \\
\text { Chang }\end{array}$ \\
\hline & Revista & In. Jr. Mineral Processing & & & \\
\hline
\end{tabular}

\begin{tabular}{|c|c|c|c|c|c|c|}
\hline \multicolumn{7}{|c|}{ Artigo } \\
\hline \multirow{4}{*}{25} & Título & \multicolumn{5}{|c|}{$\begin{array}{l}\text { Comparative studies on flotation of aluminosilicate minerals with Gemini cationic } \\
\text { surfactants BDDA and EDDA }\end{array}$} \\
\hline & Ano & \multicolumn{5}{|l|}{2013} \\
\hline & Autores & $\begin{array}{l}\text { Zhi-qiang } \\
\text { HUANG }\end{array}$ & $\begin{array}{l}\text { Hong } \\
\text { ZHONG }\end{array}$ & $\begin{array}{l}\text { Shuai } \\
\text { WANG }\end{array}$ & $\begin{array}{l}\text { Liu-yin } \\
\text { XIA }\end{array}$ & $\begin{array}{l}\text { Guang- } \\
\text { yi LIU }\end{array}$ \\
\hline & Revista & \multicolumn{5}{|c|}{ Transaction of Nonferrous Metals Society of China } \\
\hline
\end{tabular}

\begin{tabular}{|c|c|c|c|c|c|c|}
\hline \multicolumn{7}{|c|}{ Artigo } \\
\hline \multirow{4}{*}{26} & Título & Gemini trisiloxane surfactant: Syr & esis an & flotation of & uminos & cate minerals \\
\hline & Ano & 2014 & & & & \\
\hline & Autores & Zhiqiang Huang, Hong Zhong & $\begin{array}{l}\text { Shuai } \\
\text { Wang }\end{array}$ & Liuyin Xia & $\begin{array}{l}\text { Gang } \\
\text { Zhao }\end{array}$ & $\begin{array}{c}\text { Guangyi } \\
\text { Liu }\end{array}$ \\
\hline & Revista & Minerals Engineering & & & & \\
\hline
\end{tabular}




\begin{tabular}{lllll} 
Título & $\begin{array}{l}\text { Novel alkyl bis(hydroxycarbamoyl) propionic acids for flotation separation of diaspore } \\
\text { against aluminosilicate minerals }\end{array}$ \\
27 & Ano & 2012 & & \\
& Autores & Yu-Ren Jiang $\quad$ Xin-Xin Li, Rui Feng & $\begin{array}{c}\text { Dan } \\
\text { Chen }\end{array}$ & $\begin{array}{c}\text { Jun- } \\
\text { Chuan } \\
\text { Li }\end{array}$ \\
Revista & Separation and Purification Technology & & \\
\hline
\end{tabular}

\begin{tabular}{|c|c|c|c|}
\hline \multicolumn{4}{|c|}{ Artigo } \\
\hline \multirow{4}{*}{28} & Nome do artigo & $\begin{array}{l}\text { Preparation and performance } \\
\text { flotation separation of diaspor }\end{array}$ & $\begin{array}{l}\text {-alkyl-4,4-bis(hydroxycarbamoyl) carboxylic acid for } \\
\text { yainst aluminosilicates }\end{array}$ \\
\hline & Ano & 2011 & \\
\hline & Autores & Yu-Ren Jiang & Rui Feng \\
\hline & Revista & Minerals Engineering & \\
\hline
\end{tabular}

\begin{tabular}{|c|c|c|c|c|c|c|}
\hline \multicolumn{7}{|c|}{ Artigo } \\
\hline \multirow{4}{*}{29} & Título & $\begin{array}{l}\text { Preparation o } \\
\text { diaspore from }\end{array}$ & $\begin{array}{l}\text { olyzate of hos } \\
\text { nite }\end{array}$ & ash oil ( & 1O) and it & application in separating \\
\hline & Ano & 2010 & & & & \\
\hline & Autores & Wei Sun & Kui Ouyang & $\begin{array}{l}\text { Limin } \\
\text { Zhang }\end{array}$ & $\begin{array}{c}\text { Yuehua } \\
\mathrm{Hu}\end{array}$ & $\begin{array}{l}\text { Chen } \\
\text { Chen }\end{array}$ \\
\hline & Revista & Minerals Engi & & & & \\
\hline
\end{tabular}

\begin{tabular}{|c|c|c|c|c|c|c|}
\hline \multicolumn{7}{|c|}{ Artigo } \\
\hline \multirow{4}{*}{30} & Título & The role of catic & polyacrylamic & in the re & erse flotatic & of diasporic bauxite \\
\hline & Ano & 2007 & & & & \\
\hline & Autores & Guangyi Liu & Hong Zhong & $\begin{array}{c}\text { Yuehua } \\
\mathrm{Hu}\end{array}$ & $\begin{array}{c}\text { Shenggui } \\
\text { Zhao }\end{array}$ & $\begin{array}{c}\text { Liuyin } \\
\text { Xia }\end{array}$ \\
\hline & Revista & Minerals Engine & & & & \\
\hline
\end{tabular}

\begin{tabular}{|c|c|c|}
\hline \multicolumn{3}{|c|}{ Artigo } \\
\hline \multirow{4}{*}{31} & Título & A novel depressor useful for flotation separation of diaspore and kaolinite \\
\hline & Ano & 2010 \\
\hline & Autores & GUO Jian \\
\hline & Revista & Mining Science and Technology \\
\hline
\end{tabular}

\begin{tabular}{lll}
\hline Artigo & \\
\hline 32 & Título & Dynamics simulation of tertiary amines adsorbing on kaolinite (001) plane \\
& Ano & 2011
\end{tabular}


Autores LIU Chang-miao $\begin{gathered}\text { FENG An- } \\ \text { sheng }\end{gathered} \quad \begin{gathered}\text { GUO } \\ \text { Zhen-xu }\end{gathered} \quad \begin{gathered}\text { CAO } \\ \text { Xue-feng }\end{gathered} \begin{gathered}\text { Yue- } \\ \text { hua }\end{gathered}$

Revista Transaction of Neoferrous Metals Society of China

\begin{tabular}{|c|c|c|c|c|c|c|c|c|}
\hline \multicolumn{9}{|c|}{ Artigo } \\
\hline \multirow{4}{*}{33} & Título & $\begin{array}{l}\text { Flotation and a } \\
\text { different partic }\end{array}$ & ption of quate & nary amm & nium salts & collector & on kaolinite & \\
\hline & Ano & 2013 & & & & & & \multirow{3}{*}{$\begin{array}{c}\text { Chen } \\
\text { Haochuan }\end{array}$} \\
\hline & Autores & Jiang Hao & Liu Guorong & $\begin{array}{c}\text { Hu } \\
\text { Yuehua }\end{array}$ & $\begin{array}{c}\text { Xu } \\
\text { Longhua }\end{array}$ & $\begin{array}{c}\text { Yu } \\
\text { Yawen }\end{array}$ & Xie Zhen & \\
\hline & Revista & \multicolumn{6}{|c|}{ International Journal of Mining Science and Technology } & \\
\hline
\end{tabular}

Artigo

Título

Flotation techniques for separation of diaspore from bauxite using Gemini collector and starch depressant

$34 \quad$ Ano

2010

Autores

XIA Liu-yin

ZHONG LIU

Hong Guang-yi

Revista

Transaction of Neoferrous Metals Society of China

\begin{tabular}{|c|c|c|c|c|}
\hline \\
\hline \multirow{4}{*}{35} & \multicolumn{4}{|c|}{$\begin{array}{l}\mathrm{N} \text {-(6-(hydroxyamino)-6-oxohexyl) decanamide coll } \\
\text { adsorption mechanism to diaspore }\end{array}$} \\
\hline & Ano & 2015 & & \\
\hline & Autores & Lanqing Deng & $\begin{array}{l}\text { Hong } \\
\text { Zhong }\end{array}$ & $\begin{array}{l}\text { Guangyi } \\
\text { Liu }\end{array}$ \\
\hline & & \multicolumn{3}{|l|}{ Applied Surface Science } \\
\hline
\end{tabular}

Artigo

Título Reducing the entrainment of clay minerals in flotation using tap and saline water

Ano 2014

36 Autores Di Liu Yongjun

Revista Powder Technology 


\begin{tabular}{llllll}
\hline Artigo & \multicolumn{3}{c}{} \\
\hline \multicolumn{4}{c}{ Título } & Significance of particle aggregation in the reverse flotation of kaolinite from bauxite ore \\
37 & Ano & 2015 & Xuming & Chen- & Jan D. \\
& Autores & Jing Liu & Wang & Luh Lin & Miller \\
& Revista & Minerals Engineering & & & \\
\hline
\end{tabular}

\begin{tabular}{|c|c|c|c|c|c|}
\hline \multicolumn{6}{|c|}{ Artigo } \\
\hline \multirow{4}{*}{38} & Título & \multicolumn{4}{|c|}{$\begin{array}{l}\text { Study on quantitative structure-activity relationship of quaternary ammonium salt } \\
\text { collectors for bauxite reverse flotation }\end{array}$} \\
\hline & Ano & \multicolumn{4}{|l|}{2012} \\
\hline & Autores & Yuehua Hu & Pan Chen & \multicolumn{2}{|c|}{ Wei Sun } \\
\hline & Revista & \multicolumn{4}{|c|}{ Minerals Engineering } \\
\hline \multicolumn{6}{|c|}{ Artigo } \\
\hline \multirow{4}{*}{39} & Título & \multicolumn{4}{|c|}{$\begin{array}{l}\text { Synthesis and collecting properties of novel carboxyl hydroxamic acids for diaspore and } \\
\text { aluminosilicate minerals }\end{array}$} \\
\hline & Ano & \multicolumn{4}{|l|}{2010} \\
\hline & Autores & Jiang Yu-ren & Yin Zhi-gang & $\begin{array}{l}\text { Yi Yun- } \\
\text { lai }\end{array}$ & $\begin{array}{l}\text { Zhou } \\
\text { Xiao- } \\
\text { hong }\end{array}$ \\
\hline & Revista & \multicolumn{4}{|c|}{ Minerals Engineering } \\
\hline
\end{tabular}

